\title{
PROYECTO PARA UN CENTRO DE INTERPRETACIÓN DEL INSTITUTO ANDALUZ DEL PATRIMONIO HISTÓRICO
}

\author{
Beatriz Sanjuán Ballano
}

\author{
PROYECTO FIN DE MÁSTER
}

Máster en Museología ( $1^{\text {a }}$ edición. 2000-2001)

Universidad de Granada / Consejería de Cultura, Junta de Andalucía

Tutora: Concepción San Martín Montilla 
Editor: Editorial de la Universidad de Granada Autor: Beatriz Sanjuán Ballano

D.L.: Gr. 620 - 2007

ISBN: 978-84-338-4279-4 
:)

$\because$

,

:) 
El presente proyecto se origina en el marco de la primera edición del Máster en Museología organizado por la Universidad de Granada en colaboración con la Consejeria de Cultura de la Junta de Andalucía durante el bienio 2000-2001. Fue presentado en la secretaría académica del Máster y en la dirección del Instituto Andaluz del Patrimonio Histórico en junio de 2001.

La autora agradece la inestimable ayuda prestada para la realización de este trabajo al personal del Instituto Andaluz del Patrimonio Histórico y, especialmente, a la tutora del proyecto, Concha San Martín Montilla -miembro de la Comisión Académica del Máster. 


\section{ÍNDICE}

$\begin{array}{ll}\text { Preámbulo: Patrimonio e Interpretación } & \text { p.I }\end{array}$

$\begin{array}{lll}\text { I. INTRODUCCIÓN p.8 } & \text { p }\end{array}$

1.1. Antecedentes de la institución p.9

1.1.1. Antecedentes históricos y recientes

1.1.2. Antecedentes de la difusión en la institución

1.1.3. Antecedentes del centro de interpretación

1.2. Otros antecedentes

1.2.1. Antecedentes de otras instituciones similares

1.2.2. Antecedentes de la difusión en otras instituciones

1.2.3. Antecedentes de otros centros de interpretación

1.3. Valoración de la necesidad e idoneidad del centro de interpretación p.23

$\begin{array}{ll}\text { 1.4. Valoración de las futuras funciones del centro p. } 37 & \text { p.39 }\end{array}$

$\begin{array}{ll}\text { 1.5. Nombre y contenido temático } & \text { p.39 }\end{array}$

2. DISCURSO EXPOSITIVO $\quad \mathbf{p . 4 0}$

2.1. Discurso básico y disciplinas cientificas en que se apoya

2.2. Documentación disciplinar. Historia de la investigación y estado actual

2.3. Conclusiones y principios que pretenden ser explicados

2.4. Tema principal y subtemas. Organización y secuenciación

3. CONTENEDOR

3.1. Situación. Estudio de ventajas e inconvenientes p.59

3.2. Ubicación. Estudio de accesibilidad p.61

3.3. Superficie minima requerida $\quad$ p.64

3.4. Caracteristicas arquitectónicas exigibles p.66

3.5. Descripción de los espacios: $\quad$ p.68

3.5.1. Salas de exposición permanente

3.5.1.1. Secuenciación y recorrido propuestos al visitante. Superficies necesarias; Dispositivos de exposición. Necesidades

3.5.1.2. Proyecto de iluminación

3.5.2. Salas de exposiciones temporales

3.5.3. Almacenes

3.5.4. Áreas de servicios para el público general

3.5.5. Áreas de servicios para el público escolar

3.5.6. Áreas de servicios para el público especial

3.5.7. Áreas de servicios internas

3.6. Especificaciones de señalética

$\begin{array}{ll}\text { 4. CONTENIDO } & \text { p.138 }\end{array}$

5. PROGRAMA DE CONSERVACIÓN PREVENTIVA p.157

5.1. Determinación de necesidades según el volumen y naturaleza de los bienes

5.2. Control de las constantes ambientales

5.3. Control de la iluminación

5.4. Plan de seguridad 
6. SISTEMA DE DOCUMENTACIÓN

6.1. Objetivos básicos del programa de investigación

6.2. Justificación de la elección de un sistema

6.3. Medios humanos necesarios para su puesta en marcha y mantenimiento

6.4. Medios técnicas necesarios para su puesta en marcha y mantenimiento. Justificación de su elección

6.5. Estimaciones temporales para su puesta en marcha

7. PROGRAMA DE PUbliCACIONES

7.1. Enumeración

7.2. Descripción

7.3. Financiación

8. ESTRATEGIAS DE MARKETING Y COMUNICACIÓN

8.1. Estimaciones de público potencia!

8.2. Estrategias para su sostenimiento y ampliación

8.3. Servicios para el público general

8.4. Servicios para el púbiico escolar

8.5. Servicios para públicos especiales

9. GESTIÓN

9.1. Elección del sistema público o privado

9.2. Fórmula específica de gestión

9.3. Órganos y su configuración y composición

9.4. Formas de gestión de personal

9.5. Fórmulas de participación social

10. PERSONAL

10.1. Personal directivo. Perfil, número, funciones y otras especificaciones

10.2. Personal técnico. Perfil, número, funciones y otras especificaciones

10.3. Personal administrativo. Perfil, número, funciones y otras especificaciones

10.4. Personal subaiterno y/o de servicios. Perfil, número, funciones y especificaciones

11. BALANCE PRESUPUESTARIO

11.l. Aproximación al coste de apertura

11.2. Aproximación al coste de mantenimiento

12. FINANCIACIÓN

12.1. Formas de financiación

12.1.1. Financiación de la apertura

12.1.2. Mantenimiento. Garantia de la sostenibilidad

13. EJECUCIÓN

13.1. Descripción general

13.2. Plazos y cronograma

14. PREVISIONES DE CRECIMIENTO, VARLABILIDAD Y VERSATILIDAD

14.1. Previsiones

14.2. Soluciones

15. BIBLIOGRAFIA

15.1. Bibliografia citada y consultada sobre el contenido y la temática científica

15.2. Bibliografia citada y consultada sobre Interpretación, Museologia y Museografia 
Provecto para un centro de interpretación del Instituto Andaluz del Patrimonio Histórico

\section{PREÁMBULO: PATRIMONIO E INTERPRETACIÓN}

El cuerpo de la historia es asi un hombre inundado que ha yacido largo tiempo en el lecho del mar, y crya carne destrozada se ha incrustado en toda clase de conchas, algas, corales y flores subacuáticas. Y la mayor parte de la carne está destrozada, la mayor parte de las conchas, las flores de la madreperla, el aumento de lágrimas y sangre se multiplican ${ }^{3}$

(Sylvie GERMAINE)

Hasta no hace mucho tiempo la palabra patrimonio tenía un significado primario simple y habitualmente aceptado; era la generalización colectiva derivada de la idea de una herencia ${ }^{2}$ del individuo desde un antecesor fallecido. Una mirada a través de los periódicos de hoy revelaría rápidamente que la palabra ha adquirido al menos cinco significados de comprensión mucho más amplia y aplicados a una gran variedad de contextos (TUNBRDGE and ASHWORTH, 1996)

- Recuerdo físico del pasado con significación suficiente

- Memoria individual o colectiva, recuerdo del pasado desde el presente

- Productividad cultural y artística acumulada, etiquetada a menudo como alta cultura

\footnotetext{
${ }^{1}$ GERMAINE (1993) citada por TUNBRIDGE and ASHWORTH (1996)

2 "Para referirse a aquello que se recibe del pasado se utiliza el término herencia. Herencia y patrimonio son dos nociones estrechamente relacionadas. Históricamente, podríamos conjeturar que caminan juntas para llegar a confundirse en ocasiones. La noción de patrimonio, tal como la entendemos en el sentido de aquello que poseemos, aparece históricamente cuando en el transcurso de generaciones, un individuo o un grupo de individuos identifica como propios un objeto o conjunto de objetos (...) El hombre-individuo se siente poseedor y de hecho se hace poseedor y se apropia, de una forma podrlamos decir que "natural", de parte del entomo artificial que a contribuido a producir (...) Al desaparecer, deja ese patrimonio -su casa, utensilios, campos, etc.- a sus descendientes. La herencia (...) relaciona, conecta, vía objetos fisicos, unos seres con otros; los hombres y las mujeres de ayer, con los hombres y mujeres de hoy" (BALLART, 1997:17)

${ }^{3}$ En el mismo sentido, Román Femández-Baca, director del Instituto Andaluz del Patrimonio Histórico, ha escrito: "Hemos asistido a lo largo del siglo XX a la continua evolución del concepto de Patrimonio Histórico. Desde aquellas filosofias, de principios de siglo, que estudian el Patrimonio, centrado exclusivamente en los valores estéticos o "bellas artes", hasta la definición de la Ley 16/85 del Patrimonio Histórico Español, muy extensa, que busca asegurar la protección y fomentar la cultura material debida a la acción del hombre" (FERNÁNDEZ-BACA, 1998:118)
} 
- Actividad comercial, industria del patrimonio, basada en productos y servicios con el patrimonio como componente

- Patrimonio como eufemismo del exclusivismo, racial, étnico, cultural o de otro tipo

¿Está creciendo el término demasiado?

También hasta hace relativamente poco tiempo, la idea del conjunto de la sociedad sobre el patrimonio se centraba en los objetos y los valores fundamentalmente estéticos y formales de los mismos. Esta percepción se ha ido modificando a lo largo de las dos últimas décadas. La consolidación del patrimonio histórico como gran referente cultural, expresivo de los testimonios de la acción del hombre y portador también de significados ha penetrado en la sociedad, que tiene una mayor conciencia sobre los respectivos legados culturales. Esta mayor conciencia ${ }^{5}$ sobre el legado cultural y el vínculo entre el patrimonio e identidad genera una nueva concepción del patrimonio histórico como mantenimiento y transmisión de la memoria de nuestras generaciones a generaciones futuras (10 años para innovar desde la memoria, 2000). En este sentido, Josep Ballart (1997:37) ha escrito:

Las ganas de pasado constituye hoy en día el impulso primordial que mueve el interés de tanta gente por descubrir y conservar retazos del pasado (...) ante la conciencia de pérdida de continuidad cultural que ha provocado la velocidad y escala del cambio que afecta al entorno físico y cultural de las sociedades.

Ante este panorama, el patrimonio histórico - parece concluir M. Martín parafraseando una de las definiciones de ecomuseo de G.H. Rivière (1993:191)- son "todos aquellos bienes materiales e inmateriales sobre los que, como en un espejo, la población contempla para reconocerse, donde busca la explicación del territorio donde está enraizada y en el que se sucedieron los pueblos que la precedieron. Un espejo que la población ofrece a sus huéspedes para hacerse entender, en el respeto de su trabajo, de sus formas de comportamiento y de su intimidad" (MARTIN, 1993: 6).

Por su parte, Tunbridge y Ashworth han establecido una distinción entre patrimonio e historia que nos permite hacer una caracterización del patrimonio como pasado determinado por el legado, frente a una concepción de la historia que asume la existencia de episodios del pasado que deben ser descritos -descritos imperfectamente, debido a la subjetividad del narrador y a la inevitable selección de los hechos. Desde

\footnotetext{
4 "Nuestra época es, para recoger la expresiön de Michel Parent, una prodigiosa "máquina de producir patrimonio" (LANG, 1992:9)

${ }^{3}$ Al mismo tiempo, la palabra patrimonio ha ido adquiriendo un valor de hechizo. Josep Ballart lo expresa de este modo: "... la palabra patrimonio adquiere valor de conjuro y va de boca en boca, y la gente de la calle parece que se preocupa más que antes por el pasado y la historia" (BALlaRT, 1997:10)
} 
esta perspectiva, podríamos decir que los hechos de la historia no existen hasta que el historiador los crea, mientras que patrimonio es posesión, propiedad de alguien, de un sujeto real que determina que el patrimonio existe ${ }^{6}$ :

Sólo es patrimonio lo que un grupo asume como tal en un momento histórico determinado. Sin el reconocimiento de un grupo humano, el patrimonio no deja de ser un fenómeno cultural más (FERNÁNDEZ SALINAS, v. y otros, 1996:16).

Ambos, historia y patrimonio, hacen un selectivo uso del pasado con propósitos presentes, aunque estos propósitos son bien diferentes: la historia es lo que un historiador mira recordando y patrimonio es lo que la sociedad contemporánea elige para heredar y transmitir, comunicar, seguir adelante. La distinción es sólo que, en patrimonio, los usos presentes y futuros son primordiales, los recursos más variados y la interpretación es más obvia y centrada en el producto, un producto que es consumido (TUNBRIDGE and ASHWORTH, 1996).

No obstante, aunque en concordancia con la distinción de Tunbridge y Ashworth entre patrimonio e historia, la trilogía pasado/historia/patrimonio histórico concebida por I.Rodriguez Temiño es más precisa y concluyente:

Por pasado entendemos -aclara el autor-el acontecer social y humano en el pretérito. La historia resulta ser la narración de ese pasado en el presente, estableciendo un hilo argumental y causal que tiende a explicar los acontecimientos. Como tal argumentación no puede, aunque lo pretenda, ser objetiva (...) El patrimonio histórico está emparentado con la(s) historia(s) y no directamente con el pasado. Para que un vestigio sea considerado testigo o recuerdo de una sociedad pretérita debe atribuirsele un valor añadido a su mera condición de antigüedad. Ese plus es producto de la interpretación que en cada momento se haga del pasado y, por tanto, entra de lleno en el concepto de la historia (RODRIGUEZ TEMIÑo, 2000).

Pero ¿de qué hablamos cuando nos referimos a patrimonio? El Instituto Andaluz del Patrimonio Histórico, después de operar algunos años sobre los Bienes Culturales, considera al Patrimonio Histórico, más allá del objeto, definido de forma dinámica, como unidad de acción donde confluyen diferentes disciplinas académicas, colectivos profesionales, instituciones (públicas y privadas), asociaciones y organizaciones ciudadanas con el fin de perpetuar la memoria para el futuro?.

\footnotetext{
${ }^{6}$ Asi, "la exposición de motivos de la Ley de Patrimonio Histórico Español de 1985 dice que el valor de los bienes integrantes del patrimonio histórico lo proporciona la estima que, como elemento de identidad cultural, merece a la sensibilidad de los ciudadanos, ya que los bienes que lo integran se han convertido en patrimoniales debido exclusivamente a la acción social que cumplen, directamente derivada del aprecio con que los mismos ciudadanos los han ido revalorizando" (BALLART, 1997:56)

${ }^{7}$ Romero MoraGas, Carlos citado por FerNáNDEZ-BaCA (1999:118)
} 
El patrimonio, pues, como advierte Arturo Colorado, no se refiere al arte o a su historia, ni a los museos, ni a la restauración y conservación de obras artisticas, es todo ello y a la vez mucho más. Habitualmente se entiende por patrimonio el conjunto de bienes inmuebles y de obras de arte dignas de ser conservadas y admiradas por ser testimonio del pasado y fruto del genio creativo. Pero lo que hoy denominamos como patrimonio cultural ${ }^{8}$ tiene un alcance mucho mayor al abarcar no sólo las obras arquitectónicas o arqueológicas sino también los bienes culturales de todo género, los antropológicos y científicos, los paisajes culturales y, lo que es esencial, el llamado patrimonio intangible, o sea, su valor cultural.

Los bienes del patrimonio son producto de las interacciones culturales y sociales a lo largo de la historia y deben ser integrados en nuestro sistema actual de vida. Según Colorado (1999:169 y ss.), se van perfilando en el ámbito de la tutela del patrimonio cultural una serie de objetivos y de tareas ineludibles:

1. Superar la identificación del Patrimonio Histórico como algo vetusto y pasado de moda, resaltando, por el contrario, su capacidad para mejorar la calidad de vida, al ser integrado en la vida cotidiana de los ciudadanos.

2. Fomentar que el patrimonio cultural sea considerado como algo propio, de valor irremplazable, que forma parte de nuestra identidad individual y colectiva, que hemos heredado de nuestros antepasados y que tenemos la obligación de legar a nuestros descendientes en correcto estado de conservación.

3. Dar claves de comprensión del patrimonio cultural, destacando su valor ético, histórico y comunicativo, que facilita al individuo situarse en su contexto histórico, social y cultural. Dichos valores son elementos básicos a favor del respeto a la diversidad de identidades y del desarrollo de la tolerancia, base esencial de la cultura.

En la consecución de estas tres misiones la interpretación del patrimonio se ha convertido en una herramienta básica. A la modernización del concepto patrimonial y al fomento de su consideración identitaria y de comprensión hay que añadir la democratización del patrimonio y los usos turísticos que se le están concediendo progresivamente, factores que han hecho que la interpretación se haya convertido en una necesidad para el patrimonio, para su comprensión adecuada, para su apreciación y

\footnotetext{
8 “... patrimonio, al principio llamado sólo artístico, luego, histórico-artistico y ahora, cultural. Porque lo artístico (concepción renacentista) se ubicaba dentro de la jerarquía de excelencias de la primera burguesía. Lo histórico se cargó de significado gracias al iluminismo, a las "expediciones cientificas" (...). Ya a principios del siglo XX, gracias al aporte del Estado liberal, se comenzó a identificar el patrimonio como histórico-artístico. Cualquiera de las dos de denominaciones (histórico, artístico) es insuficiente, parcial y equivoca. En cambio, dentro de la denominación de Patrimonio Cultural caben todas las concepciones del tiempo (de la historia) y los niveles de desarrollo en cualquier parte del planeta, de lo artístico, lo técnico, etc. junto a lo popular, to etnológico, es decir, todo, incluso el Patrimonio Natural Transformado, es decir, el Medio Ambiente entendido como simbiosis del patrimonio natural y del cultural" (BENAVIDES, 1995:33-34)
} 
Provecto para un centro de interpretación del lnstituto Andaluz del Patrimonio Histórico

disfrute, y para su protección frente al propio turismo y su explotación y comercialización.

De la misma manera -ha escrito Josep $\mathrm{M}^{\mathrm{a}}$ Garcia- que las telecomunicaciones y la ingeniería digital viven una revolución, [...] la utilización social del patrimonio y la gestión del tiempo libre viven también una pequeña revuelta que aumenta por efecto simpático. Esta tendencia tiene que ver con la propagación de nuevos modelos de difusión y presentación de los recursos naturales y culturales, asociados a una crisis de los modelos museisticos tradicionales, a la necesidad de reactivación económica de territoriós que a final de siglo tienen un valor importante en su patrimonio y a las necesidades de una sociedad cada vez más temática que pide que le cuenten historias, en el cine, en los restaurantes, en los canales temáticos de televisión y también cuando acceden al patrimonio. En el ojo del huracán de esta dinámica, que incorpora nuevos aforismos que tienen que ver con la calidad de la experiencia, la comunicación interactiva, la sostenibilidad, la actuación local, el desarrollo global, los nuevos yacimientos de empleo... se sitúa un concepto que en nuestro país aún puede considerarse neonato pero que lleva ya algunos años funcionando en otros paises como eje de los planes de uso de los recursos patrimoniales. Se trata de "la interpretación del patrimonio", que se ha desarrollado como una filosofia articulada en torno a un concepto integral de patrimonio y se está utilizando como método de dinamización de lugares patrimoniales (GARCí, 1999:196 y ss.).

El término interpretación del patrimonio empieza a ser común a mediados de los años ochenta en el ámbito intemacional, como heredero del hasta entonces excluyente interpretación ambiental. Hoy podemos definir la interpretación del patrimonio como "el arte de revelar in situ el significado del legado natural, cultural o histórico, al público que visita esos lugares en su tiempo de ocio" (GUERRA, Francisco citado por MORALES, 1999), un arte cuyos objetivos eran ya definidos en un modelo simple y lejano ya en el tiempo, concretamente ideado en 1957 por uno de los maestros de la interpretación, Freeman Tilden (citado por UzZELL, 1989):

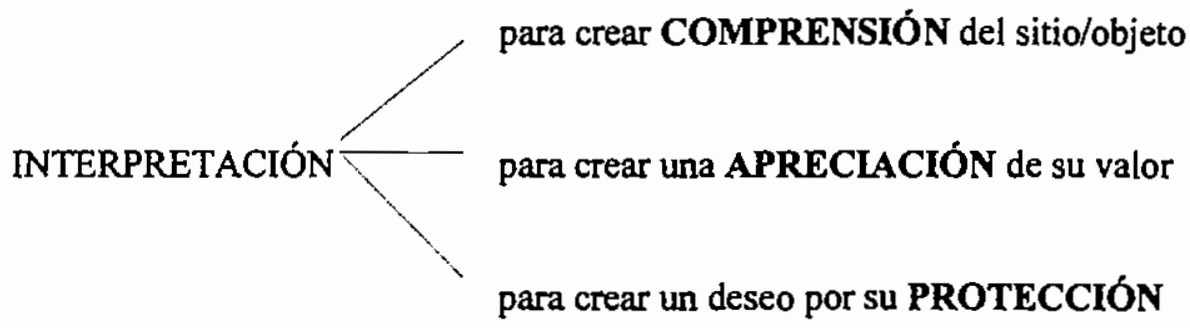


Necesidad o consecuencia de una demanda, la interpretación es hoy una herramienta ineludible si queremos poner en contacto patrimonio y público. La sensibilización de la sociedad ante su patrimonio pasa por una correcta y adecuada difusión de éste, una difusión que, dadas las cada vez mayores pretensiones del público al que es destinada, ha de ser también cada vez más exigente consigo misma. La difusión del patrimonio, la técnica de la interpretación del patrimonio son ineludibles en el feliz cumplimiento de la tutela patrimonial, han de ser el último eslabón que cierra y que abre de nuevo el circulo de la tutela del patrimonio:

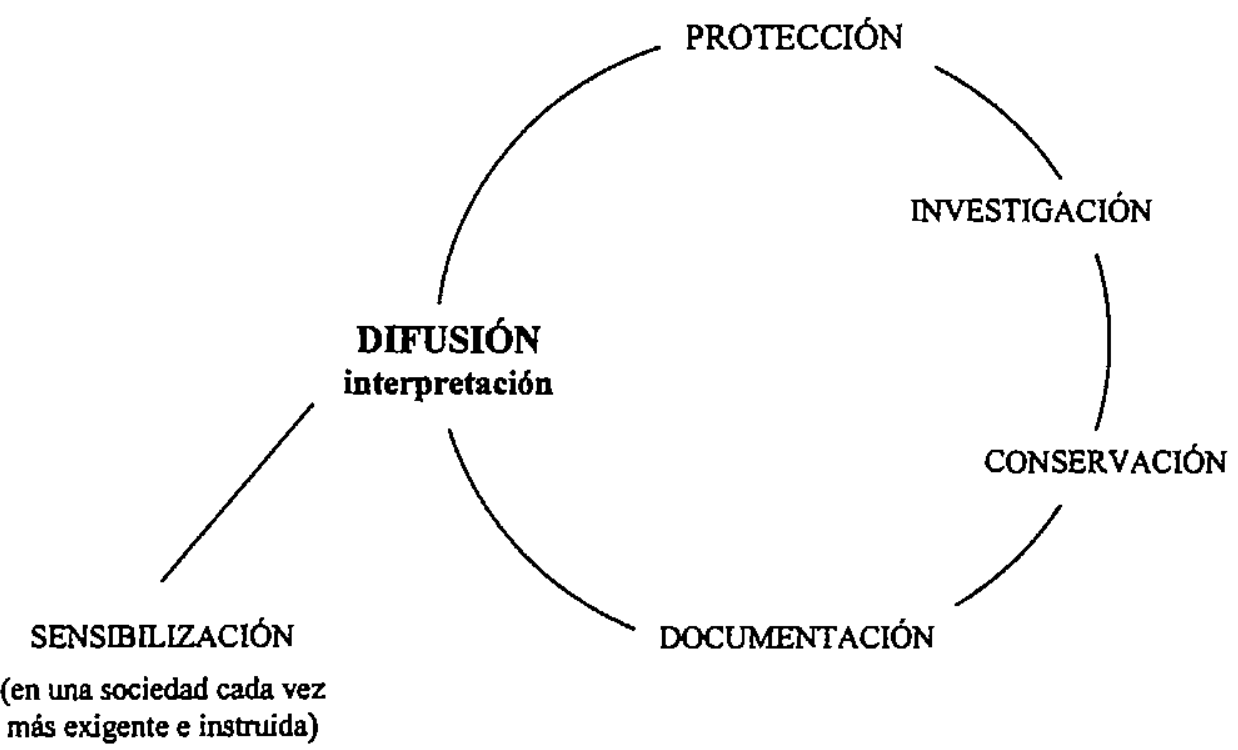

De acuerdo con este esquema, es imprescindible proteger para investigar, conocer para conservar, conservar para documentar, documentar para difundir y sensibilizar para proteger. No hay modo de proteger verdaderamente el patrimonio, si la sociedad en la que éste se engloba no es sensible a sus cuestiones; no hay modo de poseer una sensibilización social si no existe una difusión del patrimonio sistemática, rigurosa y persistente.

La interpretación, entonces, responde a una difusión ideal para el objeto patrimonial, que de por sí necesita ser identificado con valores de comprensión (investigación en su más alto grado / ilustración en el sentido de difusión pública), apreciación (sensibilización / capitalización ${ }^{9}$ ) y protección. La presentación, la interpretación y su eco visual es el vehículo mediador entre el público y el patrimonio; facilita el

\footnotetext{
${ }^{9}$ Capitalizar porque valorar el patrimonio también significa preservar un recurso económico importante para la sociedad. En forma directa o indirecta, el objeto patrimonial presentado en forma adecuada al público crea un entorno económico que favorece a los habitantes de la región y aporta fuentes de ingreso para la comunidad (SIVAN, 1999)
} 
conocimiento de los valores culturales inherentes al patrimonio histórico y, en consecuencia, despierta la conciencia sobre la importancia de su protección y conservación para beneficio de la sociedad (SIVAN, 1999). Así, la interpretación es clave en la ya máxima del patrimonio: no se puede valorar lo que se desconoce y no se puede conservar lo que no se valora. A lo que se podria añadir: no se puede valorar ni conservar lo que no se difunde adecuadamente ... y la interpretación es una adecuada manera de comunicar, la manera más común para el hombre de producir significado.

La interpretación del patrimonio es un servicio público, el público tiene derecho a disfrutar del patrimonio, derecho a sentirlo, a comprenderlo [...] y las instituciones públicas tienen el deber de facilitar ese acercamiento (MORALES, 1998). Por supuesto, este público es, tiene que ser, un público general visitante, que se encuentra, individualmente o en grupo, visitando algún sitio con valor patrimonial en su tiempo de ocio. Para Jorge Morales, autor de Guía Práctica para la Interpretación del Patrimonio, "el esfuerzo interpretativo es un sutil eslabón que une al público con el lugar que visita. La unión es sutil puesto que se trata de entrar en lo más íntimo del individuo, de que la esencia de las cosas penetre en su conciencia, toque sus valores, sus convicciones y, sin cambiarlos (no es ésa tarea de la interpretación), influya en sus actitudes, para que construya su propia versión de la verdad que tiene ante sí (MORALES, 1998:45).

Para Christian Carrier, la interpretación tiene además, siempre, una doble dimensión: cultural y personal. Cultural porque cada grupo social produce unos valores, unos conocimientos con interpretaciones más o menos homogéneas; personal porque la interpretación está marcada por la propia sensibilidad, emotividad o experiencia personal. La interpretación de cada uno sería así la conjunción de las interpretaciones subjetivas más las apropiadas por la comunidad a la que pertenece. A esta flexibilidad, riqueza y carácter de apariencia casual de la interpretación hay que anadir su condición de convicción y creencia, lejos de toda certeza o verdad objetiva -aqui, en el proceso interpretativo, la certeza se suple por la legitimidad, la verdad por honestidad.

Desde una perspectiva más hermenéutica, pero de excepcional oportunidad, Susan Sontag (1996) entiende que la finalidad de todo comentario [...] debiera ser hoy el hacer que las obras [...] -y, por analogia, nuestra experiencia personal- fueran para nosotros más, y no menos, reales. La función de la crítica [y, por ende, de la práctica interpretativa] debiera consistir en mostrar cómo es lo que es, incluso qué es lo que es, y no mostrar qué significa.

En definitiva, en tiempos de abigarramiento conceptual, ausencia crítica y escepticismo posmoderno, la interpretación viene a significar un respiro para el objeto, para la propia comunicación. Más realidad, más explicación, más información, menos especulación. Así vamos a entender aquí el concepto de interpretación aplicada al patrimonio. Comunicando la transparencia, y recuperando nuestros sentidos, los sentidos de los destinatarios a los que nos dirigimos. 



\title{
1.1. ANTECEDENTES DE LA INSTITUCIÓN
}

\subsubsection{ANTECEDENTES HISTÓRYCOS Y RECIENTES}

Para hablar dé los antecedentes del Instituto Andaluz del Patrimonio Histórico, de la institución que va a servir de marco y de contenido al centro de interpretación que proyectamos, no hay modo mejor que recordar las palabras pronunciadas en la conferencia que el director de la institución, Román Fernández-Baca Casares, ofreció con ocasión del I Seminario Internacional de Institutos de Patrimonio', celebrado en abril del año 2000 en la sede del IAPH. Fernández-Baca, único director de la institución en sus once años de existencia, hace de la siguiente manera una semblanza de aquellos primeros pasos:

\begin{abstract}
"Las cosas se van construyendo en el camino y en la historia del Instituto Andaluz del Patrimonio Histórico el primer acontecimiento relevante se produce en el Seminario Italo-español, (...) justamente en la fecha del 6 y 10 de octubre de 1987. El Seminario, no sin problemas, pues hubo gran debate entre italianos y españoles, era un Encuentro sobre restauración arquitectónica, (...) y sirvió para ver nuestras diferencias con el modelo italiano, pero también sirvió para conocer sus Instituciones y organización, y en concreto visitamos el Instituto Central de la mano de Alessandro Bianchi"
\end{abstract}

Román Fernández-Baca recuerda que por aquellas fechas (enero-febrero de 1988) se inicia la elaboración del Plan General de Bienes Culturales ${ }^{2}$, nombrando Director Técnico a Pedro Salmerón, e iniciando la reflexión sobre la organización y los modelos referenciales de la institución (fundamentalmente los tres modelos básicos fueron el de Italia -Istituto Centrale per il Restauro, ICR-, el de Madrid -entonces Instituto de Conservación y Restauración de Bienes Culturales, actual Instituto de Patrimonio Histórico Español, IPHE- y el de Bruselas -Institut Royal du Patrimoine Artistique,

\footnotetext{
' Fragmentos no literales de la conferencia pronunciada por el Director del Instituto Andaluz del Patrimonio Histórico, Román Fernández-Baca, en el marco del I Seminario Internacional de Institutos de Patrimonio (Sevilla, abril de 2000)

2 El I Plan General de Bienes Culturales de Andalucia, para el periodo 1996-1999, fue un instrumento -vanguardista por su filosofia en el marco administrativo español- para racionalizar la actuación de la administración cultural de la Comunidad Autónoma de Andalucia en el campo del patrimonio histórico (Decreto 106/1995, de 25 de abril)
} 
IRPA-), asi como los primeros pasos de creación del Decreto de fundación del Instituto Andaluz del Patrimonio Histórico ${ }^{3}$ hasta su nombramiento, el 1 de enero de 1990, como director de la institución:

"Pero, ¿cuáles eran los modelos entonces para nosotros, cuáles eran aquellos modelos que vimos en nuestras visitas? Tuvimos la ocasión de ser iluminados por Alessandro Bianchi, en una conferencia en Baeza sobre el modelo del Istituto Centrale per il Restauro (ICR), y vimos que, aún existiendo una gran tradición en la tutela y operatividad de los bienes culturales desde siempre en Italia, incorporaban nuevas aportaciones técnicas y cientificas que no implicaban la eliminación de lo artesanal sino su enriquecimiento. Se trataba de un Centro cientifico de coordinación de criterios, órgano especializado que trabajaba en proyectos piloto y que ha evolucionado, con el tiempo, a órgano de asistencia y escuela de parimonio.

Otro modelo fue el Instituto de Conservación y Restauración de Bienes Culturales [hoy Instituto de Patrimonio Histórico Español, IPHE], que se definia fundamentalmente como modelo de Instituto de Conservación en línea con el Instituto italiano. Su primera estructura, que es la estructura que conociamos, se inicia con un área de estudios previos, departamentos de información e investigación y las áreas de bienes muebles y bienes inmuebles, donde estaban obras de arte, libros, documentos, monumentos, arqueologia, y el área de programas. Se situaba muy en el campo del objeto y tampoco desarrollaba un alto grado de formación ni de transferencia y normalización en sus trabajos, seguin nuestro criterio.

Con este panorana, la creación del IAPH no es discrecional sino a través de un programa especial del Plan, en el marco de una Organización territorial, que define claramente sus funciones como Institución especializada de la Organización de los Bienes Culturales ${ }^{4}$. El Instituto Andaluz del Patrimonio seria así una unidad especializada que no se repetiria clónicamente en el territorio sino que buscaría un papel singular, fundamentalmente en el campo de la investigación y los desarrollos, y hoy dia tambièn en la innovación, para el desarrollo de apoyos especializados, para trabajar en proyectos modélicos y transferir sus trabajos a través de servicios especializados. Sus funciones están básicamente contenidas en las de estudios cientificos y el desarrollo de teorias, métodos y técnicas, la documentación y la información, la investigación de la tutela y sus Instituciones, la ejecución de programas,

${ }^{3}$ Decreto $107 / 1989$, de 16 de mayo, por el que se crea el Instituto Andaluz del Patrimonio Histórico

${ }^{4}$ Es fundamental también en los momentos de creación del IAPH y en la definición de sus líneas filosóficas, programas y estructura el documento interno denominado Objetivos y Programas del Instituto Andaluz del Patrimonio Histórico en marzo de 199l, que ratifica el carácter integral e investigador que el marco juridico-administrativo otorga a la institución (Decreto de Creación y Programa Especial del IAPH para el I Plan General de Bienes Culturales) 
planes, proyectos, la formación especializada, y la colaboración y cooperación en el marco de sus actividades.

Su estructura general, en principio en el Decreto, se definia en tres áreas: de documentación, de intervención y una Secretaria. Casi no existe presencia de la formación y de la comunicación, casi no existen ni en el Decreto ni en la estructura, pero eso se ha ido rediseñando en el tiempo sobre cinco áreas: documentación, intervención, formación, comunicación $y$, de reciente incorporación, el Centro de Arqueología Subacuática".

En la citada conferencia, el director del IAPH comenta también que, de los primeros documentos que realiza el Instituto Andaluz del Patrimonio, destaca uno redactado en 1994 (Concepto, funciones y servicios del Insituro Andaluz del Patrimonio, función social, y propuesta de planificación). En este importante documento teórico se hablaba de "armonización de criterios cientificos, necesidades técnicas con la rentabilidad social, implementación disciplinar, es decir, la interdisciplinaridad en los proyectos del Instituto, la suma de conocimientos, la búsqueda de un lenguaje común patrimonial, el mayor nivel de especialización, la búsqueda también de nuevos perfiles profesionales en relación al patrimonio [...] Esto es tarea de todos, no solamente del Instituto, de todo el conjunto de los bienes culturales donde el Instituto se situaría en el impulso y desarrollo de trabajos más especializados, vértices de la acción genérica patrimonial, apertura de fronteras, caminos, y donde existiera un mayor nivel de dificultad o empleo de tecnologia [...] Acercamiento al patrimonio de la sociedad..."

Diez años después de ese primet documento el Instituto Andaluz del Patrimonio Histórico ha desarrollado muchos de sus originarios presupuestos. Pero en el Patrimonio -advierte el director de la institución- persisten riesgos e impactos, muchas veces irreparables:

"Por tanto, esto, a todos, especialmente a nosotros, nos obliga a un gran esfuerzo investigador, operativo, formativo, educacional, que requiere el uso de la imaginación, de la creatividad, de recursos tecnológicos, de la suma de conocimientos y alianzas en el proyecto patrimonial, de la articulación de organizaciones preparadas para abordar estos retos del siglo XXI en las misiones globales de la tutela, eje de la acción, y también en los desarrollos concretos experimentales y en los desarrollos en el territorio periférico de Andalucía.

Nosotros, desde este Instituto, queremos estar situados en el marco de la innovación, atentos a la función social de nuestra actividad, mediadores entre agentes e Instituciones en el Patrimonio, permanecer como unidades dinámicas impulsoras de la dinamización y estar vinculadas al sistema de trabajo de la organización. También como Institución definidora de criterios, normalización, metodologia, nuevas tecnologías, proyectos y producción de calidad en el Patrimonio, sin menospreciar la creatividad, y avanzando en la sensibilización en 
el Patrimonio segun tres ámbitos: una unidad de conocimiento global, una unidad de intervención, y una unidad de transferencia, que corresponden la primera al Centro de Documentación, la segunda al de Intervención, y la tercera al ámbito de Formación-Comunicación.

Necesitamos consolidar la Institución definitivamente. Es débil en su estructura administrativa y en sus recursos humanos. Debemos reforzar lo que es la transferencia con otras unidades de la propia organización y externas a la propia Administración, que genere una mayor coordinación inter-administrativa de carácter transversal y optimización de los recursos administrativos. Queremos seguir profundizando en investigación, considerando esos otros marcos que ya son de referencia, como es el marco andaluz, el marco nacional y europeo de investigación, desarrollando un ajuste de la organización en el marco de una regulación interna que nos permita proyectos más transversales, impulsando la transferencia y los servicios especializados, continuando en la integración y territorialización, sobre todo en el marco de Patrimonio, sociedad y desarrollo, y apostando por un intento de mayor sensibilización a las nuevas generaciones en el campo del Patrimonio".

\title{
1.1.2. ANTECEDENTES DE LA DIFUSIÓN EN LA INSTITUCIÓN
}

\begin{abstract}
“Difusión (técnica), promoción (mercado), divulgación (comunicación), educación (paideia) son casi sinónimos par una misma función, que clamando en el desierto, nos haga llegar a otra tierra sin prometer y deseada"
\end{abstract}

(GALLARDO, 1999)

Ya en los primeros documentos definidores de la institución se habla de la importancia de una "síntesis continua de la dialéctica Patrimonio / Instituto / Sociedad", de un "papel mediador y conector de acciones diversas en torno al patrimonio" (Objetivos y Programas del Instituto Andaluz del Patrimonio Histórico en marzo de (991), porque "definida la necesidad de reconocer, proteger y enriquecer el patrimonio cultural andaluz, surge de forma inmediata el concepto de difusión, entendiendo como tal la acción de propagar, divulgar y dar a conocer dicho patrimonio a la comunidad (...)".

El Instituto Andaluz del Patrimonio Histórico en sus diez años de existencia ha entendido -en palabras del responsable de Comunicación de la institución, Marcelo Martin- su difusión y la difusión del patrimonio como una gestión mediadora entre el

\footnotetext{
${ }^{5}$ Asi aparece ya recogido en el Decreto de creación de la institución, que marca, como primera función del IAPH, "el análisis, estudio, desarrollo y difusión de las teorias, métodos y técnicas aplicados a la Administración, Protección, Investigación, Difusión, Conservación y Restauración del Patrimonio Histórico y de sus Instituciones"
} 
Patrimonio y la sociedad. Gestión, porque implica un proceso complejo que abarca documentar, valorar, interpretar, manipular, producir y divulgar un producto comprensible y asimilable en relación con su pasado histórico y su medio presente cultural, porque se opera con la obra del hombre, tangible e intangible en el ciudadano de hoy, hasta ser parte de su historia, y por tanto su identidad; y mediadora, porque requiere de una política, de un programa, de una técnica y un soporte material independiente del objeto y ajena al sujeto que la recibe.

La difusión del patrimonio no es, entonces, tarea de un solo agente cultural. Puede y debe haber difusión del patrimonio en la escuela, el archivo, la biblioteca, la oficina de turismo, la asociación vecinal o la casa de cultura de un municipio. El vinculo entre el patrimonio y la sociedad requiere de un entramado de esfuerzos, tanto de gestión como de innovación, un proceso de carácter territorial y coordinado, el conocimiento y valoración de nuestra herencia y el reconocimiento de las demandas de nuestra sociedad . $^{6}$

En este marco de transferencia social y de íntima conexión en el territorio, se habrá de insertar, pues, el proyecto de un centro de visitantes para la institución, que, a su vez, estará engastado en el programa de difusión de la institución, proyectado hace diez años y materializado en las siguientes vías de comunicación:

\section{- Línea editorial / Publicaciones}

- Boletín PH: Se trata de una publicación trimestral, un órgano especializado en los ternas de Patrimonio, en el que tienen cabida informaciones y opiniones diversas. Ha sido una referencia informativa y un foro de debate especializado en el ámbito de la tutela, documentación, intervención o investigación del Patrimonio Histórico, tanto a nivel regional, como nacional e internacional. Se trata de una de las pocas publicaciones de estas características editadas en Europa y casi la única generada desde las estructuras de una administración autonómica de cultura.

- Cuademos y Cuadernos Técnicos: Colecciones de publicaciones que conforman un corpus teórico-práctico encargado de reflejar los nuevos enfoques metodológicos en materia de tutela, conservación, documentación, gestión y difusión de los bienes culturales. A través de una selección rigurosa se pretende plasmar en esta colección una serie de actuaciones modélicas o de documentos esenciales para la formación y actualización profesional de las actividades vinculadas al patrimonio.

- Seminarios, jomadas, cursos-debate, etc.: La difusión a través de congresos, seminarios o jornadas de debate es un excelente nexo de unión con la comunidad

\footnotetext{
6 Texto de Marcelo Martin, responsable del Departamento de Comunicación del IAPH. Publicado en 10 años para innovar desde la memoria (2000)
} 
especialista e interesada en el patrimonio histórico. Hasta el año 2000, el área de Comunicación del LAPH ha organizado una treintena de eventos de este tipo.

- Exposiciones: En su relación con el exterior, el IAPH ha encontrado igualmente apoyo en la elaboración y proyección de exposiciones sobre sus trabajos más significativos o la propia institución. Aproximadamente una decena de exposiciones han sido presentadas y excelentemente acogidas por el público ${ }^{7}$.

- Stands: La difusión mediante stands se ha llevado a cabo en dos ocasiones: la primera, en 1997, en el Salón Internacional del Patrimonio Cultural (SIPAC) de Santiago de Compostela; la segunda en el año 2000, con la participación en la Feria Intemacional ARPA, en Valladolid.

- Jomadas de Puertas Abiertas: El día 28 de junio de 1996, el Instituto Andaluz del Patrimonio Histórico celebró unas Jomadas de Puertas Abiertas a las que acudieron 800 personas. Este hecho destaca especialmente por ser la primera experiencia de difusión del IAPH en contacto con el público general.

- Visitas: : Desde marzo de I996, el IAPH recibe visitas técnicas a sus instalaciones de profesionales y estudiantes universitarios fundamentalmente. Puente de relación entre la institución y la sociedad, el sistema de visitas especializadas constituye uno de los puntos fuertes de la difusión del IAPH:

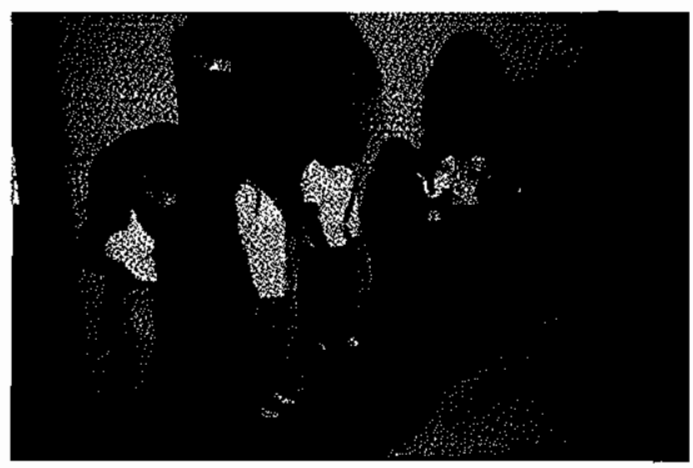

De algún modo -y como se puede comprobar en el siguiente apartado- algunas de estas herramientas de difusión conforman los antecedentes más directos del Centro de Interpretación que aquí se propone realizar.

\footnotetext{
${ }^{7}$ La exposición Do.Co.Mo.Mo. sobre arquitectura moderna en España, por ejemplo, alcanzó los 680 visitantes

${ }^{8}$ El sistema de visitas del IAPH es analizado más profundamente en otros apartados, especialmente en el capítulo 8, dedicado al público potencial del Centro de Interpretación
} 


\subsubsection{ANTECEDENTES DEL CENTRO DE INTERPRETACIÓN}

Pero la difusión, para el IAPH, es también interpretación. Es la actividad que permite convertir el objeto patrimonial en producto patrimonial, a través de un proyecto que integre la interpretación y la comunicación. La primera se entiende como la materialización de la definición conceptual del bien convertido en mensaje inteligible, y la comunicación, como un proceso de identificación y satisfacción de las necesidades del usuario. Todo ello implica un conjunto de actividades destinadas a dar a conocer, valorar y facilitar el acceso a la oferta cultural ${ }^{9}$. El centro de interpretación que ahora estamos proyectando es una actividad más de la difusión del IAPH, una actividad que se pretende interpretadora y comunicadora del objeto que representa la propia institución.

El centro de interpretación del Instituto Andaluz del Patrimonio Histórico es una idea que surge en el seno de la institución -dirección y comunicación- desde mediados de los años noventa a partir de la constatación de una cierta madurez de la institución y del reconocimiento de la relación de éxito que mantiene el LAPH con su público. Con un público, por un lado, suscriptor de la revista; por otro, asistente a exposiciones, jomadas y seminarios. A ello hay que añadir la creciente demanda de visitas a la sede en los últimos cinco años, una demanda que acaba por probar que la siempre pretendida biunivocidad IAPH/sociedad es real, fructifera y altamente satisfactoria. Estas constataciones llevan ineludiblemente a la concepción de un centro de interpretación, para satisfacer de mayor grado la demanda obtenida hasta el momento y para tener la posibilidad de fomentar esta demanda. Fomento que, sin la creación de un centro de interpretación, y por motivos expuestos en el apartado 1.3., es verdaderamente imposible de afrontar.

Ya en el año 2000, en la publicación conmemorativa de los diez años de existencia del Instituto Andaluz del Patrimonio Histórico, 10 años para innovar desde la memoria, se hace referencia a la "realización de un proyecto de un Centro de Visitantes del IAPH como experiencia modélica". Y en un documento interno -considerado aquí antecedente conceptual de centro de visitantes-, Marcelo Martin escribe:

En el ámbito de la difusión del IAPH se encuadra la tarea de dotar al Instituto de una imagen nitida, socialmente acorde y cientificamente válida de cara a la comunidad para la que se trabaja. Las caracteristicas de una institución de investigación aplicada $y$ de trabajo multidisciplinar y modélico dentro de la gestión del patrimonio plantean una complejidad importante a la hora de acercar al público en general y a los visitantes especializados en particular la labor del IAPH. Por fal motivo es que se viene trabajando desde hace tiempo en el proyecto de generar una explicación de

\footnotetext{
9 Texto de Marcelo Martín, responsable del Departamento de Comunicación del IAPH. Publicado en 10 años para innovar desde la memoria (2000)
} 
carácter interpretativa en la propia sede y que supere el marco de las visilas de grupo que se vienen realizándose como única via de vinculación público/LAPH

$Y$, aparte de estos precedentes conceptuales, otros hitos de la historia de la difusión en el IAPH habian sido - tal vez involuntariamente- de especial influencia en el centro de interpretación:

I. La exposición sobre el IAPH de 1996 es, a nuestro juicio, el gran antecedente del centro de interpretación, la primera y única experiencia expositiva de la institución, sus departamentos y actividades hasta el momento. Se realizó en las instalaciones del Instituto, en una zona cercana a la proyectada para el futuro centro de interpretación, y su filosofía estaba inspirada en la difusión de la institución a un público menos especializado, más general.

2. La Jomada de Puertas Abiertas de 1996, celebrada paralelamente a la exposición anterior, sirvió para que un gran número de visitantes no especializados pudieran conocer la institución. El éxito de esta actividad puso de manifiesto el interés que subyacia en el público, así como la necesaria, y escasamente fomentada, relación público general/LAPH. De igual modo, se pudo comprobar que la apertura de la institución a un público más amplio exigía una remodelación del sistema de visitas, una concepción diferente del mostrar la institución.

3. Las visitas especializadas realizadas desde 1996, su evolución en positivo y su incremento potencial, son en sí mismas otro gran antecedente del centro, especialmente al observar que el aumento de visitas ha sido espeluznante en cuanto al número de visitas de centros escolares de bachillerato, lo que significa un aumento del visitante más general que del especializado, un aumento del interés por conocer la institución del público menos técnico.

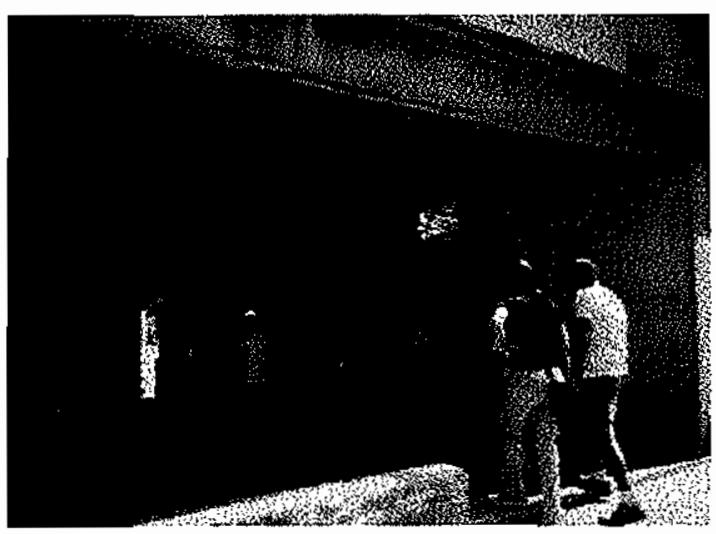




\subsection{OTROS ANTECEDENTES}

\subsubsection{ANTECEDENTES DE OTRAS INSTITUCIONES SIMILARES}

El Instituto Andaluz del Patrimonio Histórico, como institución de la Consejería de Cultura de la Junta de Andalucía encargada de la investigación, conservación y documentación del Patrimonio Histórico andaluz está vinculada originariamente con otras instituciones con las que comparte intereses, objetivos y perspectivas. A continuación hacemos unas breves referencias de algunos de estos centros, para, posteriormente, comentar sus actividades de difusión.

Las instituciones que vamos a describir escuetamente son $^{10}$ :

- Instituto de Patrimonio Histórico Español (IPHE)

- Istituto Centrale per il Restauro (ICR)

- Institut Royal du Patrimoine Artistique (IRPA)

- Instituto Nacional de Antropologia e Historia de México (INAH)

- Instituto do Patrimônio Histórico e Artístico Nacional (Brasil)

- Centro Internacional para la Conservación del Patrimonio (CICOP)

- Dirección de Arquitectura y Patrimonio del Ministerio de Cultura (Francia)

- The Getty Conservation Institute

- Instituciones de UNESCO: ICCROM y Centro de Patrimonio Mundial

- Instituto de Patrimonio Cultural (Venezuela)

- The Smithsonian Institution

El Instituto de Patrimonio Histórico Español (IPHE) es la institución encargada de la conservación del patrimonio histórico en España. Sucesor del antiguo Instituto de Conservación y Restauración de Bienes Culturales" , creado por Real Decreto en 1985, al IPHE "le corresponde la elaboración de planes para la conservación y restauración del Patrimonio Histórico Español, el estudio de métodos y técnicas actualizadas para la restauración y conservación del mismo, el archivo y sistematización de los trabajos realizados en cada caso concreto, la formación de técnicos y especialistas que atiendan a. los fines del Instituto, así como la propuesta de celebración en su caso de Convenios con

\footnotetext{
${ }^{10}$ Aunque, como se ha comentado anteriormente, el Instituto Andaluz del Patrimonio Histórico tiene tres modelos de referencia básicos en el momento de su creación (ICR, antiguo IPHE e IRPA), en este apartado se ha recogido toda institución similar al IAPH que resulta de interés para el proyecto

"I A su vez, sucesor del Instituto de Conservación y Restauración de Obras de Arte, ICROA
} 
otras Administraciones Públicas y Entidades Públicas o privadas necesarias para el desarrollo de su funciones específicas" (Instituto de Conservación y Restauración de Bienes (ulturales, 1990:9). En la actualidad, y tras el reparto de competencias con la España de las Autonomías, el IPHE toma una postura de colaboración con otras instituciones autonómicas, e intenta mantener esa vocación de formación especializada, esa inicial vocación de transmisión, a la vez que intenta consolidar nuevas inquietudes, especialmente la consolidación de la variedad temática de las intervenciones, el desarrollo de la investigación aplicada a la intervención y la consecución de convenios de colaboración con instituciones extranjeras (VIÑAS TORNER, 2000).

En lo que se refiere al lstituto Centrale per il Restauro (ICR) -una de las primeras instituciones en atender la restauración de obras desde unos planteamientos de absoluto rigor cientifico y en concebir la obra en su contexto- hay que señalar que se trata de una institución de larga trayectoria que combina la interdisciplinariedad (en él trabajan arqueólogos, historiadores del arte, restauradores, arquitectos, físicos, químicos o biólogos) con la variedad, debido a la existencia de once secciones de restauración diferenciadas por materiales, desde pinturas murales a papel y pergaminos. En la actualidad el ICR cuenta con gran credibilidad en Italia y fueta de ella.

En cuanto al IRPA de Bruselas, creado en 1948, hay que destacar su consagración al estudio y la conservación de bienes artísticos y culturales de Bélgica con unas misiones de investigación y de servicio al público, muy similares a las del LAPH. Concebido desde los años sesenta para facilitar la aproximación interdisciplinar de las obras de arte, está dividido en tres departamentos interrelacionados en los que trabajan historiadores del arte, fotógrafos, químicos, físicos y conservadores-restauradores.

Otra institución, el INAH, es también de referencia ineludible. El Instituto Nacional de Antropologia e Historia de México nace en 1939 bajo una perspectiva antropológica, acorde con la realidad de grupos indigenas y grandes mayorías marginadas en el pais. El diseño de la institución parte, pues, de un compromiso ético-social. En la actualidad, el INAH se asemeja más a un Ministerio de Cultura que a una institución de conservación y documentación del patrimonio, debido, por un lado a su gran capacidad de decisión -muy concentrada, y, a la vez, repartida entre todos los Centros del INAH, tantos como Entidades Federativas tiene el pais- $y$, por otro, debido a su inmenso patrimonio, tangible e intangible. Para corroborar su ingente actividad, basta decir que, en el año 2000, el Instituto hacía frente a 2.500 intervenciones en monumentos históricos y a 250 proyectos de investigación y conservación de tipo arqueológico.

En una perspectiva similar trabaja el Instituto do Patrimônio Histórico e Artístico Nacional de Brasil, vinculado al Ministerio de Cultura. Creado en 1937, este Instituto se preocupa por la preservación del patrimonio cultural brasileño. Su acción se desenvuelve por medio de 14 dependencias regionales y 19 subregionales, que se encargan de la tutela, protección y restauración del Patrimonio. El sistema de museos nacionales también es coordinado por este Instituto, cuyo trabajo puede ser reconocido en los más de 16.000 edificios tombados, 50 centros y conjuntos urbanos y 5.000 sitios arqueológicos catalogados. 
En otro sentido, el CICOP (Centro Internacional para la Conservación del Patrimonio), cuya sede en España se ubica en Canarias, es una institución no gubernamental cuyo objetivo primordial es la cooperación intemacional en tomo al patrimonio fisico de los pueblos y que se plantea el Patrimonio Histórico Artístico con la máxima cualificación en la asistencia cientifica y técnica, mediante la colaboración con instituciones gubernamentales y universidades. Entre los objetivos del Centro Internacional para la Conservación del Patrimonio destacan el establecimiento de un marco teórico en el que se incluyan los aspectos definitorios de los Bienes Culturales, los criterios de valoración y de análisis y el nivel de tutela a que deben someterse y el apoyo a la Administración en los casos preferentes de expedientes que afecten a Bienes Culturales necesitados de una intervención protectora de carácter urgente.

El Centro Internacional para la Conservación del Patrimonio se vertebra en tomo a cinco departamentos que agrupan tareas especializadas en el campo de la Formación multidisciplinar, la Investigación, el Análisis, la Intervención y las Publicaciones y Divulgación. El CICOP cuenta a su vez con la participación de expertos y colaboradores nacionales e internacionales en el campo de la conservación y restauración que con su experiencia colaboran en la formación e investigación de futuros expertos en este campo.

Es interesante también hacer referencia a la Dirección de Arquitectura y Patrimonio del Ministerio de Cultura francés, creada en 1998 con la misión de estudiar, proteger, conservar y hacer conocer el patrimonio arqueológico, arquitectónico, urbano, etnológico, fotográfico y las riquezas artísticas de Francia. Este centro tiene el siguiente organigrama: dirección, inspección, servicio de investigación, servicio de conservación y servicio de comunicación.

El Getty Conservation Institute (GCI), que nació en 1982 como un programa del J.Paul Getty Trust, se encarga de actividades de conservación y formación, de conservación e interpretación. El Instituto sirve a la comunidad internacional a través de la investigación científica sobre la naturaleza, alteraciones y tratamientos de materiales y proyectos modélicos de intervención, donde la interdisciplinariedad de profesionales es fundamental.

Por su parte, UNESCO cuenta con dos centros o instituciones relacionadas con el patrimonio y en cierto modo asimilables al IAPH que es imprescindible reseñar aqui:

- El ICCROM, Centro Internacional de Estudios de Conservación y Restauración de los Bienes Culturales, es un organismo intergubemamental que suministra asesoria técnica acerca de la conservación de los sitios inscritos y formación en técnicas de restauración. El ICCROM fue creado en 1956, su sede está en Roma, y es un activo asociado de la Red de Información del Patrimonio Mundial. 
- El Centro del Patrimonio Mundial de la UNESCO, que fue creado en 1992, tiene, entre otras tareas, las de organización de seminarios y talleres técnicos, la actualización de la Lista del Patrimonio Mundial y la base de datos correspondiente, la elaboración de material educativo para promover el interés respecto a la noción de Patrimonio Mundial, y mantener informado al público respecto a cuestiones del Patrimonio Mundial. El Centro coopera con otros grupos de trabajo en temas relacionados con la conservación tanto dentro de la UNESCO - con la División del Patrimonio Cultural del Sector de Cultura, por ejemplo-, como en el exterior, concretamente con los tres órganos asesores -el ICOMOS, la UICN y el ICCROM- y con otras organizaciones intemacionales tales como la Organización de las Ciudades del Patrimonio Mundial (OCPM) y el Consejo Intemacional de Museos (ICOM).

Finalmente, hay que destacar la actividad del Instituto del Patrimonio Cultural de Venezuela, que se creó en 1995 integrando la Dirección de Patrimonio del CONAC (Consejo Nacional de Cultura) y el Centro de Conservación del Patrimonio CECOP, creado por la UNESCO. El Instituto ha protagonizado un cambio planificado de la gestión del patrimonio cultural a través de la mejora de la organización y el desarrollo de nuevas estrategias para el cumplimiento de metas y objetivos.

\subsubsection{ANTECEDENTES DE LA DIFUSIÓN EN OTRAS INSTITUCIONES}

En cuanto a la actividad difusora de las instituciones antes descritas, destaca la labor, mentalidad y talante comunicativo del ICCROM, que se plasma indefectiblemente en todos sus proyectos. La concepción holística de este organismo acerca de todo cuanto relaciona al Patrimonio Histórico, una concepción en la que nunca falta el interés por la proyección social de sus trabajos, se ve completada por su preocupación en buscar y lograr la implicación, cooperación y complicidad de los medios de comunicación. En este sentido, es irreprochable y loable su constante trabajo en conseguir una estrecha relación con la prensa local, radio y televisión del territorio en el que se inserta cada proyecto, con la intención de alcanzar una adecuada difusión del patrimonio, una correcta transmisión de su sentido y, sobre todo, una mayor sensibilización de la sociedad y del público ${ }^{12}$.

Similar mérito, aunque a una escala más local, se puede conceder al área de difusión del Instituto de Patrimonio Cultural de Venezuela, cuya Unidad de Divulgación y Relaciones Públicas está destinada a establecer y poner en práctica la política informativa, gráfica y editorial, tanto interna como externa. Entre sus funciones destacan la planificación y dirección de campañas de información hacia los medios de

${ }^{12}$ Es de gran interés, por poner un caso entre muchos, la labor realizada en África, a través del proyecto PREMA (Prevention in museums of Africa) 
comunicación social sobre actividades y proyectos, así como la coordinación y ejecución de la política editorial a través de publicaciones impresas periódicas y no periódicas, la difusión del conocimiento relativo al patrimonio a través de la edición de publicaciones, la promoción y proyección de una imagen institucional favorable entre públicos internos y externos. la difusión de experiencias y conocimientos en materia de protección y defensa del patrimonio cultural, y el diseño de estrategias informativas sobre actividades y proyectos puntuales hacia los medios de comunicación social, con el objeto de promocionar y divuIgar mensajes que generen cambios en la actitud de la población hacia la protección y defensa del patrimonio cultural.

Es también reseñable, aunque se aleja del modelo hasta ahora visto de Instituto de patrimonio -de ahí que no hayamos hablado de ella en el apartado anterior-, Ia difusión llevada a cabo por la Smithsonian Institution (ver además apartado 1.2.3.), debido a sus esfuerzos por ofrecer a la comunicación un lugar respetable en la investigación global de la institución. La Smithsonian se ha dedicado especialmente a los estudios de educación de público, y sobre todo a público escolar. Estudios que son de referencia para cualquier institución que desee difundir y comunicar con eficacia su actividad.

Otras instituciones, como el Instituto Getty o el Ministerio per i Beni e le Attività Culturali de Italia, destacan por la utilización de sus páginas webs para la difusión de sus actividades. El primero, por ejemplo, cuenta con amplia información de sus modalidades de visita mientras que el Ministerio de Italia presenta una página que incluye, por poner un caso, información e imágenes sobre restauraciones en curso y restauraciones recientes. Este último caso italiano destaca, especialmente, por la difusión de su progetto mose, una experiencia pionera al ofrecer, por primera vez en directo, en internet, las tareas una de restauración altamente representativa de Italia: la escultura Moisés, de Miguel Ángel ${ }^{13}$.

Destacamos finalmente la labor del INAH, con su enorme producción de libros -unos 250 al año- y revistas, y la del CICOP, que cuenta con una interesante Unidad de Infografia y Espacio Virtual (U.I.E.V) que desarrolla técnicas de animación en tres dimensiones con aplicación en ordenador o en vídeo sobre los edificios históricos del Patrimonio Arquitectónico. Estas técnicas consisten en una restitución infográfica que permite visualizar el contenedor histórico en tres dimensiones, aplicando texturas de los materiales originales y consiguiendo un programa interactivo de grandes efectos didácticos para el usuario. El usuario puede interactuar recorriendo el contenedor histórico, deteniéndose donde desee y conocer información sobre cualquier detalle del monumento. Todo el programa se puede volcar a vídeo para usuarios que lo utilicen en grupos numerosos, pudiendo tener un fondo musical y comentarios en off.

\footnotetext{
${ }^{13}$ Para la visualización del proyecto Moisés, la dirección web es: progettomose.it. Si se desea conocer el resto de actividades de difusión via internet en Italia: icr.arti.beniculturali.it y benicuiturali.it/restauri/instituti
} 


\subsubsection{ANTECEDENTES DE OTROS CENTROS DE INTERPRETACIÓN}

No existe en la actualidad ninguna institución similar al IAPH que cuente con un centro de interpretación o visitantes que explique y haga comprender sus actividades, misiones, funciones.

Sin embargo, el centro de interpretación del IAPH cuenta con un referente muy válido, aunque prácticamente único: The Smithsonian Information Center, de la Smithsonian Institution. Este centro ofrece información diversa y cuenta con un programa de orientación que asiste al visitante de la Smithsonian, un programa que incluye guías y mapas, planificaciones para diferentes tipos de visitas y públicos, calendarios de actividades, paneles con respuestas a las más frecuentes preguntas y enlaces visuales con otras instituciones de interés. Además, el centro muestra presentaciones continuas de vídeo de 24 minutos acerca de la Institución, puntos de orientación, pantallas interactivas sobre Ia Smithsonian en seis idiomas, diferentes maquetas a escala, murales electrónicos y módulos táctiles, asi como guías gratuitos en siete idiomas y voluntarios para ofrecer información especializada.

El IRPA de Bruselas, aparte de su actividad editorial en la que plasma los resultados de sus investigaciones (Bulletin), también cuenta con interesantes actividades de difusión, que podemos considerar antecedentes indirectos de nuestro Centro de Interpretación: Nos estamos refiriendo a las Jomadas de Puertas Abiertas para visitar el IRPA y las exposiciones didácticas y periódicas que organiza la institución acerca de sus trabajos. 


\title{
1.3. VALORACIÓN DE LA NECESTDAD E IDONEIDAD DEL CENTRO DE INTERPRETACIÓN
}

\begin{abstract}
Toda iniciativa de proporcionar interpretación será abordada de forma metódica en función de umas necesidades reales identificables en el terreno
\end{abstract}

(MORALES, 1998:61)

Hasta el momento actual, el Instituto Andaluz del Patrimonio Histórico cuenta con un sistema de visitas bastante afianzado que, tras varios años de funcionamiento, presenta una afluencia de peticiones cada vez mayor, aunque restringida desde la institución por razones que a continuación se detallan ${ }^{14}$. Estas razones fundamentan la necesidad de un centro que lo interprete y explique, y transfiera sus objetivos, funciones y razón de ser con calidad y sin limitaciones.

Antes de argumentar la necesidad e idoneidad del centro de interpretación, veamos los recursos con los que cuenta la institución, los recursos que fundamentarán a su vez una futura interpretación.

\section{EVALUACión De LOS RECURSOS DE LA INSTITUCión}

El Instituto Andaluz del Patrimonio Histórico cuenta con los siguientes recursos interpretativos ${ }^{15}$ :

EMPLAZAMIENTO

- Está enclavado en un edificio singular y conocido de la ciudad, próximo al Monasterio de La Cartuja, el Centro Andaluz de Arte Contemporáneo y la Universidad Internacional de Andalucia. Situado en la Isla de la Cartuja, el Instituto Andaluz del Patrimonio Histórico dispone de una sede rehabilitada con ocasión de la

\footnotetext{
${ }^{14}$ Ver también capitulo 8

15 Algunos criterios se han extraido de MORALEs, 1998:176 (Matriz para la Evaluación del Potencial Interpretativo, adaptada de Badaracco y Scull -1978-, y Morales y Varela -1986-)
} 
Exposición Universal de 1992. La Cartuja es hoy un espacio de arte y cultura, sede de instituciones tan relevantes como la Universidad Internacional de Andalucia, el Centro Andaluz de Arte Contemporáneo y el Instituto Andaluz del Patrimonio Histórico.

SINGULARIDAD

- El edificio y su rehabilitación son singulares arquitectónicamente. El edificio, por la combinación de homos y chimeneas, claustros y campanarios procedentes de su pasado fabril y religioso; la rehabilitación, por su sintonia entre restos antiguos y nueva arquitectura.

- La institución en si es singular para el público general, sobre todo por el trabajo de restauración que realiza.

PÚBLICO

- Afluencia de público en aumento ${ }^{16}$

- Varios años de visitas reincidentes al IAPH conforman una clientela, un público asegurado y fiel, de profesores especialmente, que anualmente visitan la institución con alumnos diferentes ${ }^{17}$

- En el caso de las visitas académicas o didácticas, se cuenta con un valorable conocimiento previo por parte del público, que ya ha escuchado en clase la existencia de la instituciọn ${ }^{18}$

- En otras ocasiones, desde la perspectiva de un público más general, el conocimiento previo de la institución es debido a la restauración de imágenes religiosas procesionadas en la Semana Santa sevillana y andaluza. Se trata, pues, de un conocimiento imperfecto, de un recurso que mejorar. A continuación se hace un análisis de las informaciones referidas al Instituto Andaluz del Patrimonio Histórico aparecidas en el Diario de Sevilla, desde mayo de 1999 (prácticamente desde su creación) hasta diciembre del año 2000 -es decir, 20 meses- obtenemos importantes datos

\footnotetext{
${ }^{16}$ analizada en el apartado de Estimaciones del Público Potencial, capítulo 8

17 Íbidem.

${ }^{18}$ Íbidem.
} 
que ponen de manifiesto la incorrecta, por parcial, información que recibe la sociedad acerca del IAPH:

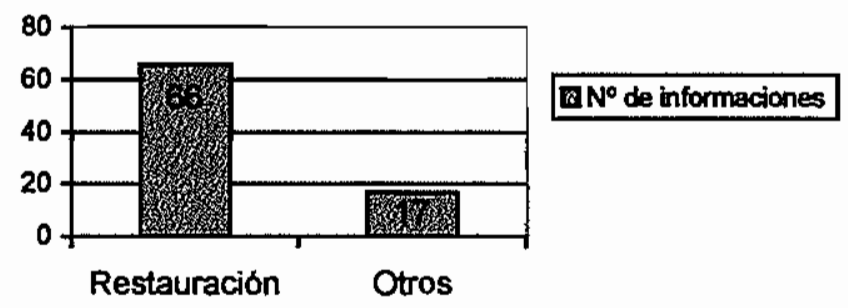

De las 83 informaciones sobre el Instituto Andaluz del Patrimonio Histórico aparecidas en el Diario de Sevilla desde su creación hasta diciembre del año 2000,66 (es decir, un $79 \%$ ) tienen como tema principal los aspectos de restauración o intervención del IAPH. El resto, 17 (un 21\%) se refiere a otras cuestiones, detalladas a continuacion:

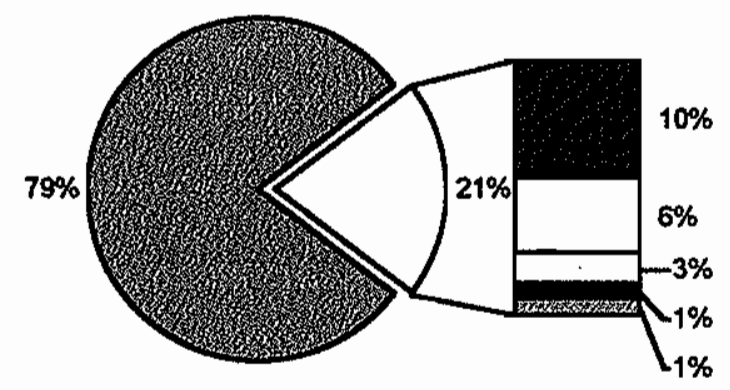

\begin{tabular}{|l|}
\hline Restauración \\
Documentación \\
$\square 10$ ahos \\
$\square$ Cursos \\
cas \\
OPaleobiologla
\end{tabular}

De las informaciones aparecidas en Diario de Sevilla referidas a temas de restauración, destaca el número de informaciones dedicadas a la intervención de alguna pieza u obra en concreto, representando un $57 \%$ del total de informaciones sobre el IAPH. Este porcentaje es, a nuestro juicio, el que determina la imagen parcial e incompleta que la sociedad tiene de la institución: 


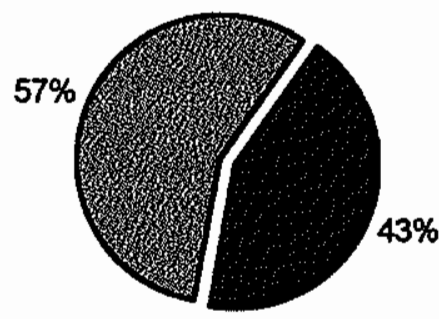

国Restauración pieza concreta

Otras

informaciones

Seguidamente detallamos la composición de ese $57 \%$ referido a intervenciones sobre piezas concretas, y vemos cómo más de la mitad de ellas (24 en concreto) son informaciones sobre 5 piezas que han ocupado la máxima atención por parte del Diario de Sevilla: Giraldillo, obras intervenidas con ocasión de la exposición Velázquez y Sevilla, la pintura Sagrada Cena de Murillo, la obra escultórica Cristo de la Coronación de Espinas de la Hermandad del Valle de Sevilla y el Simpecado de la Hermandad del Rocío de Villamanrique de la Condesa.

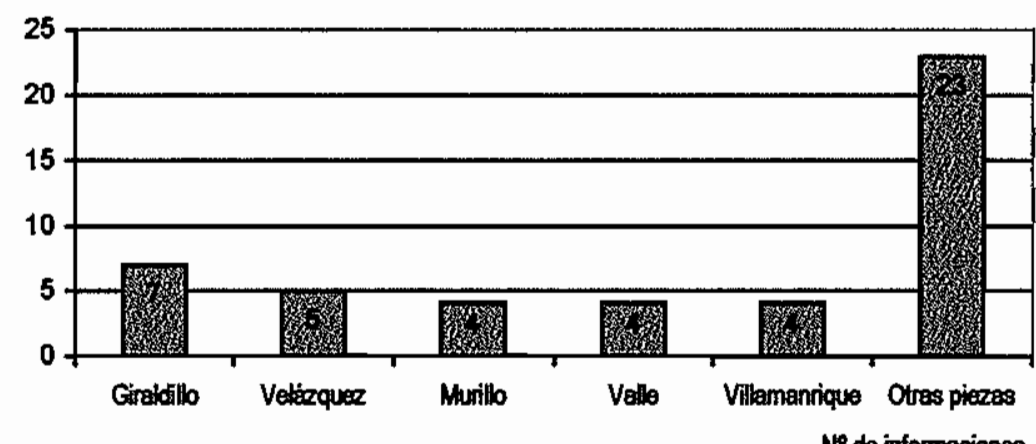

Haciendo un recuento de las informaciones referidas a intervención en generah, obtenemos este análisis: 


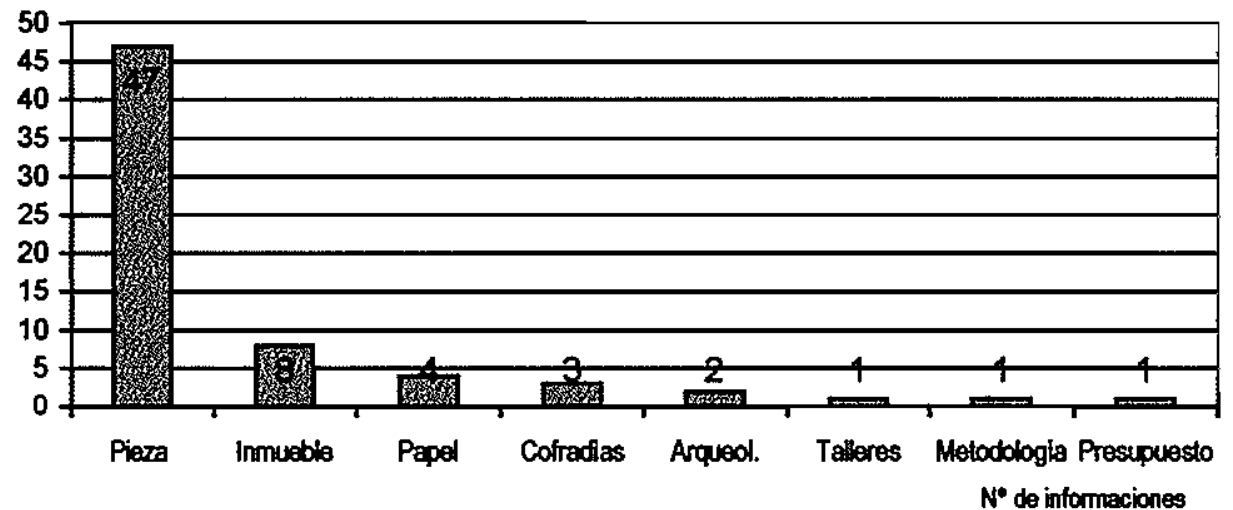

$\mathrm{Y}$ analizando, por último, las informaciones no referidas a intervención (recordemos que sumaban un mínimo $17 \%$ ) resulta:

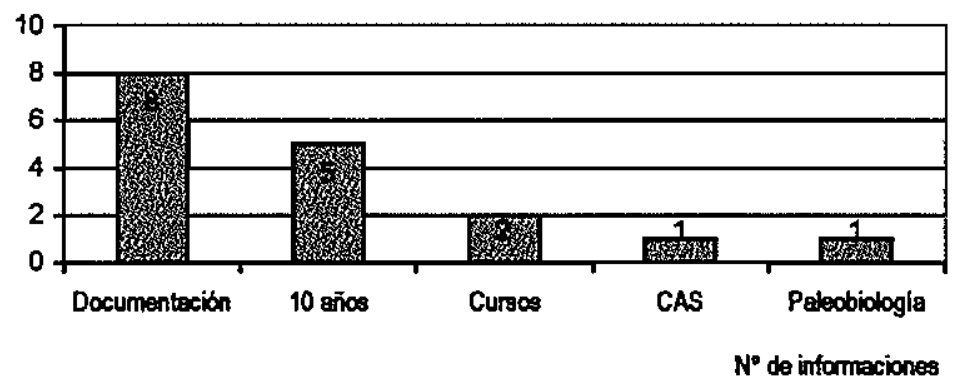

- El aumento del número de visitas de Institutos de Bachillerato -la mayoría de ellos imparten la asignatura "Patrimonio Histórico de Andalucía"- en los dos últimos affos es significativo de una demanda real ${ }^{19}$.

- Se cuenta además con un público potencial nuevo, dispuesto a una visita, fácil de captar: el visitante que llega al Monasterio de La Cartuja y al Centro Andaluz de Arte Contemporáneo.

${ }^{19}$ Íbidem. 


\section{PERTINENCIA DE CONTENIDOS}

- El contenido presenta gran adaptabilidad a casos concretos, experiencias de primera mano y a través de los sentidos. Finalmente, uno de los trabajos que se realizan, el de restauración, es de gran atracción para el público general.

\section{INSTALACIONES}

- Existen salas desocupadas y de amplias dimensiones, listas para albergar un centro de interpretación

Haciendo una escala de valores, que subdivide las valoraciones en altas, medias o bajas y basada en la "Matriz para la Evaluación del Potencial Interpretativo; adaptada de Badaracco y Scull (1978), y Morales y Varela (1986)" (definida en MORALES, 1998, p.176) los recursos interpretativos del IAPH son muy altos, con lo que la necesidad e idoneidad de un centro de visitantes también ha de serlo entonces, al menos si queremos explotar esos recursos, darles la máxima difusión, acercarlos a la sociedad. El cuadro de valores resultante es el siguiente:

\begin{tabular}{|l|c|c|c|}
\hline \multicolumn{1}{|c|}{ RECURSO } & $\begin{array}{c}\text { Valoración } \\
\text { alta }\end{array}$ & $\begin{array}{c}\text { Valoración } \\
\text { media }\end{array}$ & $\begin{array}{c}\text { Valoración } \\
\text { baja }\end{array}$ \\
\hline Emplazamiento & & $\mathrm{x}$ & \\
\hline $\begin{array}{l}\text { Singularidad } \\
\text { arquitectónica } \\
\text { tematica }\end{array}$ & $\mathrm{x}$ & $\mathrm{x}$ & \\
\hline $\begin{array}{c}\text { Público } \\
\text { incremento } \\
\text { fidelidad } \\
\text { conocimiento } \\
\text { Bachilleratos } \\
\text { - Monasterio/CAAC }\end{array}$ & $\mathrm{x}$ & & \\
\hline Pertinencia de contenidos & $\mathrm{x}$ & & $\mathrm{x}$ \\
\hline Instalaciones & $\mathrm{x}$ & $\mathrm{x}$ & \\
\hline
\end{tabular}


El emplazamiento ha obtenido una valoración compensada entre la valoración alta y la baja debido a la media resultante entre la consideración positiva de que el Instituto Andaluz del Patrimonio Histórico se encuentra en un conjunto monumental, de carácter cultural y de gran proyección social, y la consideración más negativa de la ubicación lejana a la ciudad, con las consecuentes dificultades de acceso, transporte y comunicaciones. No obstante, esta desventaja del emplazamiento, la lejania de la sede, es más psicológica que real, puesto que a pie, desde el centro de la ciudad, solamente hay quince minutos; además, existe una linea de autobús de doble sentido que tiene parada en la puerta del Monasterio. A ello hay que añadir que la accesibilidad rodada es muy buena, por su excelente comunicación con SE-30 y rondas de circunvalación, y que existen amplios espacios para aparcamiento.

En cuanto a la singularidad arquitectónica, se ha valorado altamente positiva, al ser la sede del IAPH un edificio histórico rehabilitado para un uso institucional y cultural. Rehabilitación que, por otro lado, ha recibido importantes premios y galardones, entre los que destacan la IV Bienal de Arquitectura Española (1997) y la I Bienal Iberoamericana de Arquitectura e Ingeniería (México, I998).

La singularidad temática ha sido también muy valorada, debido a la admiración que supone, tanto para el público general como para el público especialista, la actividad de la restauración, una actividad mágica para unos, privilegiada para otros.

El público es uno de los grandes recursos con los que cuenta la institución, de ahi que se haya valorado muy altamente. Por un lado, se cuenta con un público muy fiel, que repite anualmente su visita (como se pone de manifiesto en el análisis de visitas, capítulo 8), por otro, con un público escolar -que es el gran visitante en potencia nuestro punto de mira principal- $y$, por otro, con un público potencial -que acude motivado por el Centro Andaluz de Arte Contemporáneo y/o el Monasterio de La Cartuja- dispuesto, simplemente, a visitar. EI incremento de visitas en general, especialmente las de institutos de bachillerato, es un recurso altamente positivo para el proyecto de centro de interpretación y de valor para la institución, que tiene la oportunidad de explotar y dar vía de salida; de lo contrario, se corre el riesgo de en una deficiencia de la institución, que habrá sido incapaz de acoger las necesidades, demandas e intereses de la sociedad. El conocimiento previo ha sido cuantificado negativamente, pues, aunque es cierto que muchós de los visitantes que acuden a la institución llegan con ciertos conocimientos de ésta, la sociedad u opinión pública en general -que es nuestro objetivo- tiene un conocimiento desvirtuado de las actividades del IAPH, o, un conocimiento fragmentario, a menudo restringido al Centro de Intervención, como ponen de manifiesto los análisis de contenido de la información aparecida en prensa en los últimos años acerca de la institución. De aquí que este recurso pueda convertirse en una desventaja, al contar con un público potencial que conoce la existencia de la institución de una manera prefijada y fragmentaria, que será dificil de modificar.

La pertinencia de contenidos es otro de los recursos de la institución que hay que tener en cuenta y valorar, pero con reservas. De una parte contamos con contenidos de fácil 
adaptación experimental y de alto atractivo, pero que presentan, en algunos casos, demasiada complejidad científica y especializada para su transmisión de un modo sencillo.

Finalmente, las instalaciones de un futuro centro de interpretación son muy valoradas, pues la propia institución cuenta con salas espaciosas y sin un uso especifico hasta el momento. Además, estas salas, en planta baja y con grandes posibilidades de iluminación natural, no presentan barreras ni impedimentos arquitectónicos.

Tras estos resultados, podemos asegurar que el Instituto Andaluz del Patrimonio Histórico posee importantes recursos explotables desde la perspectiva de la interpretación. De los diez valores encontrados -numerosos, a nuestro juicioencontramos que nueve de ellos obtienen una calificación media o alta.

\section{EVALUACIÓN DE LA NECESIDAD DE UN CENTRO DE VISITANTES}

La valoración de la necesidad e idoneidad de la creación de un centro de interpretación del Instituto Andaluz del Patrimonio Histórico está íntimamente ligada a dos preguntas clave, ya clásicas, del Patrimonio: ¿por qué lo hacemos? y ¿para qué sirve? Partiendo de la realidad de la institución y de la práctica de visitas que se ha estado realizando hasta ahora, varios aspectos hacen que el centro de visitantes sea absolutamente necesario, si estamos buscando, efectivamente, un sistema de visitas acorde con el funcionamiento de la institución y su coherencia en el área de comunicación. Los argumentos de la necesidad de un centro son:

\section{IMPACTO}

- El área de talleres sufre un impacto real con las visitas. Existe una posibilidad de perjuicio para las obras en proceso de restauración, tanto en lo referente a riesgo físico (golpes, rasguños con levantamientos de capa pictórica) como a alteraciones derivadas de los cambios de temperatura y humedad relativa producidos con la entrada de grupos masivos a talleres.

- El ambiente interno de trabajo también se ve perjudicado: distracción de los trabajadores con el trasiego de visitantes, realización de tareas que no les competen-como explicaciones y demostraciones-, interrupción de su actividad y del ritmo de trabajo de la institución. 
PÚBLICO

- Necesidad de llegar a un público más general, lo que representa tanto un interés como una obligación, pues las instituciones públicas tienen el deber de llegar y concienciar a un público lo más amplio posible. No se trata, por lo tanto, de excluir de la difusión del PH a todas aquellas personas que no posean la preparación necesaria para interpretar los hechos u objetos históricos, sino que es conveniente enseñar, acostumbrar y ayudar a esa gran mayoría de la sociedad a utilizar criterios interpretativos que le faciliten la comprensión de esos hechos u objetos más allá de lo puramente anecdótico (MARTíN, 1993:6).

- Acceso a un público escolar (sobre todo de Institutos de Bachillerato, para los que la visita es de gran impacto y de beneficiosas consecuencias pedagógicas y didácticas). Se alcanzaría así el deseo de fomentar el Patrimonio y la concienciación para su conservación desde cortas edades, en los años de formación de una persona.

- Aumentar el número de visitantes.

\section{MODELO CONCEPTUAL}

- EI centro de interpretación del IAPH puede servir de modelo conceptual a otros organismos que tengan interés en hacer una experiencia similar (ayuntamientos, centros turísticos patrimoniales...).

CALIDAD

- Eliminación del factor azar o arbitrario en el conocimiento de la posibilidad de visitar el IAPH, dar a conocer de manera general, divulgar.

- Regularidad, normalización, evitando que unas visitas se aprovechen más que otras, en función de la calidad, cantidad o fases por las que estén pasando las obras o trabajos.

- Posibilidad de visita para discapacitados fisicos mediante módulos especiales y eliminación de barreras arquitectónicas. 
SEGURIDAD

- General

- De las obras de arte en especial

Haciendo una valoración de estas necesidades obtenemos:

\begin{tabular}{|c|c|c|c|}
\hline NECESIDAD & alta & media & baja \\
\hline $\begin{array}{l}\text { Impacto } \\
\begin{array}{l}\text { - talleres/obras } \\
\text { - laboral }\end{array}\end{array}$ & $x$ & & $\mathbf{x}$ \\
\hline $\begin{aligned} & \text { Público } \\
& \text { - } \text { general } \\
& \text { - } \text { escolar } \\
& \text { - } \text { aumento } \\
&\end{aligned}$ & & $\begin{array}{l}x \\
x \\
x\end{array}$ & \\
\hline Modelo Conceptual & & & $x$ \\
\hline $\begin{array}{ll}\text { Calidad } \\
\text { - no azar } \\
\text { - normalización } \\
\text { - barreras arquitectónicas }\end{array}$ & & & $\begin{array}{l}x \\
x \\
x\end{array}$ \\
\hline $\begin{array}{c}\text { Seguridad } \\
\text { - general } \\
\text { - } \text { obras }\end{array}$ & $x$ & & $x$ \\
\hline
\end{tabular}

Tras el análisis del cuadro, debemos hacer estas observaciones:

1. la valoración alta se corresponde con criterios que hacen necesario el centro de interpretación en un grado máximo, hasta tal punto que, de no materializarse el proyecto, las visitas se verían muy claramente perjudicadas, incluso eliminadas del esquema de difusión de la institución.

2. la valoración media se corresponde con criterios que hacen necesario el centro de interpretación en un grado menor que el anterior, de modo que, de no materializarse el proyecto, las visitas continuarian realizándose, aunque con graves limitaciones y restricciones, de número y de tipo de público.

3. la valoración baja se corresponde con criterios que hacen necesario el centro de interpretación en un grado mínimo, de modo que, de no materializarse el proyecto, las visitas continuarían realizándose, aunque otros aspectos externos a las visitas se verian perjudicados. 
Vemos, entonces, como conclusión más destacable y significativa, que hemos podido contabilizar once necesidades, dos de ellas de extremada urgencia -precisamente ambas relacionadas con la calidad del trabajo de restauración de obras.

\section{EVALUACIÓN DE LA IDONEIDAD DE UN CENTRO DE VISITANTES}

Con la creación de un centro de visitantes, aparte de cumplir con las necesidades anteriores, hallariamos razones por las que este centro se valoraría no sólo como necesario sino también como idóneo, altamente positivo para la institución. No estamos hablando ya de argumentos que hablan por sí solos, que son -podemos decirde urgencia, sino de aspectos que supondrian una mejora añadida a las visitas del Instituto Andaluz del Patrimonio Histórico.

Todas estos motivos hacen que un nuevo centro de interpretación en el IAPH resultara de una idoneidad patente:

\section{INSTRUMENTO DE IMAGEN ${ }^{20}$}

- Mejora pública de la institución y de la Administración de la que depende: por un lado, demostrando el interés de la institución por la sociedad y la difusión del patrimonio, por otro, poniendo de manifiesto su capacidad de transmisión y comunicación en el plano más real o material.

- Promoción de una comprensión pública de los fines y actividades de la institución, desde la visión de que toda entidad tiene un mensaje que transmitir a la sociedad.

- Mayor presencia pública, dando a conocer las visitas y la propia institución, incluyendo la información en los programas turisticos, educativos, culturales de la ciudad y de la comunidad.

${ }^{20}$ Un aspecto de la gestion en el que la interpretación puede jugar un papel crucial es la relativa a la imagen. Los intérpretes -y el conjunto de servicios interpretativos- pueden llegar a ser los principales "relaciones puiblicas" del organismo (Veverka y Poneleit, 1981, citados por MORALES, 1998:103)

Por otra parte, también conviene hacer una reflexión acerca de la interpretación como "la cara pública" de las instituciones, y no perder de vista su relación con la imagen -en el sentido de apariencia-. Esta relación se establece en dos sentidos: en primer lugar, la interpretación puede ser un factor crucial para la imagen de una institución (...). Y en segundo término, la imagen ya creada de la institución es vital para la credibilidad de su interpretación (Hunt, 1979): se puede encontrar un descrédito a priori o una buena acogida por parte del público debido a la mala o buena imagen de la institución, respectivamente" (MORALES, 1998:59) 
- Durante la visita, libra a la institución de tener que recordar normas, evitando así la molestia, impertinencia, ofensa o imagen de desconfianza (seguridad, bolsos, no tocar).

PÚBLICO

- Aprovechamiento de los visitantes del Monasterio de La Cartuja y Centro Andaluz de Arte Contemporáneo, visitantes fortuitos que se encuentren visitando el lugar, que vienen buscando ocio $y$ distracción, y ofrecerles una altemativa didáctica de calidad.

\section{MAYOR CALIDAD}

- Aumento de la comprensión del mensaje:

- La visita se centraliza y está organizada, con lo que la comprensión global también aumenta. Se evita la dispersión, que, debido a la propia dispersión arquitectónica de la sede de la institución, a la variedad de aspectos en los que trabaja y el propio tamaño del edificio, es muy posible. Al canalizar la visita se maximiza el tiempo real de aprovechamiento de la visita. Esta organización no significa que los contenidos estén presentados rígidamente en secuencia; hablamos exactamente de una organización conceptual.

- Módulos de contenidos o experiencias variables (pensando en que muchas visitas se repiten).

- Posibilidad de ofrecer niveles diferentes de experiencias y conocimientos.

- Se pondrían de relieve, se experimentarían o explicarían aspectos que en la actualidad es imposible atender (manejo del SIPHA, por ejemplo).

- Contenido específico para niños.

- Mejora de visitas para extranjeros, con textos en inglés.

- Facilidad para la ejemplificación.

- Más información con ejemplos, casos concretos y que resulten familiares.

- Aumento de la satisfacción del visitante (lo que repercute además en la comprensión del mensaje) derivada de:

- Más implicación del público con la visita. 
- Potenciación de la autoestima del visitante, gracias al autodescubrimiento de los mensajes.

- Más interactividad con el recurso.

- Menos imagen de visita tradicional.

- Visitantes más activos.

- Experiencia de primera mano y en la que se siente, se toca...

- Más interacción social (con otros visitantes o el grupo).

- Sensación de libertad.

- Duración de la visita más libre.

- Información amena en un contexto recreativo.

- Comunicación más atractiva.

- Calidad fisica de la visita (con repercusiones seguras en la extensión del tiempo de visita y en la satisfacción final del visitante):

- Comodidad: zonas de descanso y asientos, WC, teléfonos públicos, percheros, consignas para mochilas y bolsos, señalizaciones frecuentes, cafeteria...

- Espacio cerrado, sin necesidad de salir al exterior con inclemencias del tiempo (esto es importante en un edificio que combina constantemente espacios abiertos y cerrados).

- Horario más amplio de visitas; posibilidad de visitar por las tardes.

\section{INSTRUMENTO DE GESTIÓN ${ }^{21}$}

- La interpretación sirve a la institución para cumplir con sus deberes de difusión y conservación del patrimonio, canalizando de forma positiva las actitudes del público hacia el patrimonio. La ciudadanía, o un factor de ella, comprenderá y apreciará su patrimonio, y entrará en contacto con programas institucionales mientras disfruta de su tiempo de ocio o pedagógico.

- La reducción del impacto a las obras y al ritmo de trabajo -que hernos considerado necesario- cumple al mismo tiempo fines de gestión de la institución.

- Dotación al área de Comunicación de un nuevo instrumento para cumplir con su función de comunicación al exterior.

${ }^{21}$ En lugar de utilizar la interpretación meramente como una "valla" para disminuir el impacto del visitante, deberia ser considerada también como la cara pública de la gestión e incluso, en algunos casos, como una de las razones para la gestión (Beckman, 1987, citado por MORALES, 1998:102) 
- Alivio de otras unidades de gestión, como el área de seguridad o mantenimiento.

\section{EVALUACIÓN}

- Mejores posibilidades de evaluación de las visitas (con cuestionarios aleatorios, seguimientos de individuos al azar...), $y$, por extensión, de los fines del Departamento de Comunicación y, en última instancia, de la institución.

\section{INTERÉS AJENO}

- El Monasterio y el CAAC se verían beneficiados en cuanto a público visitante ( $y$ en instalaciones interpretativas, si es conjunto el centro).

- La ciudad y la comunidad contarian con una oferta más de calidad para sus áreas de turismo, educación y cultura.

- Aumento del transporte desde la ciudad.

Después de esta lista de criterios, la idoneidad de un centro de interpretación para el IAPH queda manifiesta al resultar que diecisiete aspectos destacan que el centro sería ideal. Diecisiete que, sumados a las doce razones por las que el centro es una necesidad, obtenemos casi treinta argumentos de apoyo a un proyecto que se mueve en un entorno avalado por diez recursos de la institución explotables muy valorados y altamente explotables. 


\subsection{VALORACIÓN DE LAS FUTURAS FUNCIONES DEL CENTRO}

Además de proporcionar una experiencia recreativa/inspiradora, el Centro de Interpretación del IAPH -en sintonía con los puntos que, según Foley y Keith (MORALES, 1999:58), reúnen y sintetizan qué se quiere lograr a través de la interpretación- busca ser:

- un instrumento para la gestión del recurso

- una estrategia "educativa" muy particular

- una herramienta para un cambio de actitud

En efecto, con una clara misión de servir de instrumento de gestión, el centro de interpretación del Instituto Andaluz del Patrimonio Histórico será de utilidad para que la institución pueda reforzar sus objetivos de difusión acogiendo y concienciando a un mayor número de visitantes, a los que se ofrece una oferta cultural de calidad sin obstaculizar el funcionamiento de la institución. Al mismo tiempo, el centro de interpretación funcionará como revulsivo de la mejora pública de la imagen de la institución en lo referido a apertura e implicación social.

El futuro centro de interpretación del IAPH podria ser punto de encuentro pedagógicodidáctico, a través del establecimiento de una estrecha relación de trabajo continuo con colegios y, sobre todo, Institutos de Bachillerato -Bachillerato de Arte-, con los que fomentar la sensibilización de los más jóvenes. El centro de interpretación podria hacer frente a la necesidad del profesorado, demandada desde diferentes foros, de tener acceso a recursos didácticos con los que poder contar y en los que necesita apoyarse a la hora de abordar la enseñanza en la Educación Secundaria sobre todo en lo que se refiere a asignaturas tan concretas y recientes -como la denominada "Patrimonio Histórico de Andalucía"- que se imparten hasta el momento con muy escaso material curricular especifico. El Instituto Andaluz del Patrimonio Histórico podría ser, entonces, la institución-motor en el impulso y desarrollo de ciertos materiales curriculares para Bachilleratos de Arte y Ciencias Sociales, en estrecha colaboración con los responsables de los Centros de Profesorado de Educación Secundaria y con los Gabinetes Pedagógicos de Bellas Artes ${ }^{22}$ y utilizando como piedra angular su centro de interpretación o visitantes, que contaría a su vez con salas especiales de actividades y talleres para escolares.

${ }^{22}$ Los Gabinetes Pedagógicos de Bellas Artes se definen como servicios conjuntos de las Consejerias de Educación y Ciencia y de Cultura. Su objetivo es facilitar el acercamiento del Patrimonio Histórico a la Escuela, para lo que ofrece los siguientes recursos: materiales didácticos; información y coordinación de visitas; cursos para profesorado sobre didáctica del Patrimonio Histórico; asesoramiento para actividades y asesoramiento a grupos de trabajo en materia de Patrimonio 
Haciendo uso de la máxima del IAPH como institución $I+D$, el Centro de Interpretación -también en consonancia con la vocación del Instituto Andaluz del Patrimonio Histórico por ser referencia modélica en Andalucia- tendrá la posibilidad de ser referencia en cuestiones de investigación sobre las teorias y prácticas interpretativas culturales y patrimoniales, una vez haya alcanzado el nivel de calidad de difusión deseable y haya encontrado un equilibrio con las actividades complementarias que este proyecto prevé. A su vez, será centro de investigación y documentación sobre el IAPH (su historia, evolución, organización y funcionamiento, etc.) y sobre la comunicación y el público en el propio centro de visitantes ${ }^{23}$.

De igual modó, el Centro de Interpretación del IAPH podría liderar una red de centros de interpretación del patrimonio en Andalucía, con objeto de facilitar el debate y la investigación sobre la interpretación pero también para conectar con más fuerza y facilidad en circuitos turistico-culturales.

Finalmente, siguiendo con la equiparación al modelo institucional y sus funciones básicas, el Centro de Interpretación deberia proporcionar asistencia técnica y apoyo formativo a Ayuntamientos, empresas, asociaciones, organizaciones o instituciones que desearan incorporar a sus actividades de difusión un centro de visitantes o de interpretación.

${ }^{23}$ Estas líneas de investigación serán definidas en el apartado 6, sobre el Sistema de Documentación del Centro de Interpretación 


\subsection{NOMBRE Y CONTENIDO TEMÁTICO}

El término que estamos utilizando en la realización de este proyecto, Centro de Interpretación del Instituto Andaluz del Patrimonio Histórico, será obviado en la fase de concreción real del mismo, pues, como ha alertado Jorge Morales en numerosos escritos y foros, el término mismo interpretación es habitualmente rechazado por el público general visitante que buscamos atraer. La misma palabra Centro es, por lo demás, demasiado general y abarcadora, pero ante la inhabilidad de encontrar un término más acogedor y preciso (el de aula se acercaba a nuestra intención pero, en determinadas circunstancias podia resultar más confuso que el de centro) nos decidimos por ella.

En general, aunque otras denominaciones propuestas habían sido Centro de explicación del Instituto Andaluz del Patrimonio Histórico ${ }^{24}$ y Centro de información del Instituto Andaluz del Patrimonio Histórico ${ }^{25}$, finalmente seleccionamos la designación Centro de visitantes del Instituto Andaluz del Patrimonio Histórico, por resultar el más coherente con la finalidad y uso que tendrá el centro.

El Centro de Interpretación presentará un contenido temático claramente conceptual, definido en las funciones, acciones, productos y servicios del Instituto Andaluz del Patrimonio Histórico. De este modo, el contenido priorizará las ideas sobre los objetos, y éstos estarán siempre al servicio de aquéllas. En concreto, el contenido temático del Centro de Interpretación versará sobre los Centros de Documentación e Intervención del IAPH, sobre sus departamentos de Formación y Comunicación y el Centro de Arqueología Subacuática. Asimismo, conceptos de carácter más general, como los de patrimonio o tutela patrimonial, o la historia de la sede de la institución, también serán explicados.

\footnotetext{
${ }^{24}$ Consideramos que la denominación Centro de explicación del Instituto Andaluz del Patrimonio Histórico no es suficientemente explicita de lo que nosotros queremos dar a entender con nuestro centro de interpretación, ya que no sólo buscamos una explicación de nuestra institución sino toda una transmisión y transferencia social que pasa por un proceso de difusión y sensibilización mucho más amplio que la mera explicación

${ }_{25}$ Por otro lado, Centro de información, aunque puede ser bastante elocuente para un visitante entra en colisión con otra área del IAPH, el Servicio de Información -perteneciente al Centro de Documentación. Entendiamos que no convenía este solapamiento, ni al nuevo Centro de interpretación, ni al Servicio de Información, ni, por supuesto, al propio Instituto
} 


\section{DISCURSO EXPOSITIVO}




\subsection{DISCURSO BÁSICO Y DISCIPLINAS CIENTÍFICAS EN QUE SE APOYA. HISTORIA Y ESTADO ACTUAL}

El contenido es un atisbo de algo, un encuentro como un fogonazo

(W. DE KOONING)

La globalidad que representa una institución, su interdisciplinariedad, sentido, finalidad y funciones serán el sustrato, el discurso de nuestro centro de interpretación. Nos alejaremos así de la tradicional interpretación del objeto para acercarnos a la interpretación del concepto, en línea con la siguiente afirmación de Josep $\mathrm{M}^{\mathbf{a}}$ García:

En su sentido más semiótico, por interpretación del patrimonio se entiende el conjunto de métodos y de dispositivos a través de los cuales se intenta dar vida o significado a los objetos patrimoniales que están separados o despojados de su contexto original. Asi pues, la interpretación puede sustentarse en objetos patrimoniales aislados, en conjuntos (a veces más o menos homogéneos) o en paisajes (urbanos, industriales, rurales o naturales) aunque también puede basarse en personajes, hechos históricos, conceptos, narraciones... (GARCiA, 1999: 196 y ss.)

Para la comunicación de este concepto que es el Instituto Andaluz del Patrimonio Histórico, optaremos por un discurso temático no jerarquizado centrado en la siguiente conceptualización del objeto de interpretación:

El LAPH es una institución de investigación y desarrollo que incluye la documentación, la intervención, la comunicación y la formación de recursos humanos de manera modélica dentro de la gestión integral del patrimonio andaluz en su contexto territorial

Un discurso, pues, centrado en las competencias administrativas otorgadas a la institución, lo que significa un discurso centrado en la estructura orgánica de la institución por centros y departamentos'.

' En el discurso expositivo, el Patrimonio Arqueológico Subacuático será considerado de manera integrada en el conjunto Patrimonio Histórico general y el Centro de Arqueología Subacuática, aunque se explicitará claramente su estructura y organigrama, se difuminará entre los grandes módulos que vertebran nuestro discurso, coincidiendo con las disciplinas que lo sustentan de modo que se pueda percibir el modelo funcional del CAS como un espejo del 
El gran discurso se divide a su vez en unidades discursivas, de manera que, en cada unidad, se desarrolla a su vez otro subdiscurso temático no jerarquizado donde se presentan e interpretan cada uno de los principios básicos que la sustentan. Se trata en definitiva de generar un árbol de secuencias en las que el visitante pueda referir cada trabajo o cada tarea a una rama especifica sin perder de vista la globalidad o el carácter multidisciplinar que significan el patrimonio y la propia institución (aquí incidirá el leit motiv del recorrido, denominado El Círculo del Patrimonio ${ }^{2}$ ). De este modo, se pretenderá un discurso global -en el sentido de transdisciplinar, integral, completo y total- al tiempo' que concreto y preciso -nunca abstracto- en su plasmación final. En cualquier caso, el discurso habrá de caracterizarse por el predominio de los contenidos informativos (frente a los contenidos valorativos) con el objeto de lograr la máxima claridad en la exposición de las ideas y la mayor eficacia en la transmisión de los temas. Sumado a este rasgo informativo, el discurso subyacente combinará elementos persuasivos no manipulativos y alentadores de la reflexión e incluso de la acción, buscando la complicidad de todos los tipos de público, indiferentemente de sus edades, formación o intereses. Un discurso sorpresivo y que llame al impacto y la curiosidad, de itinerario y recorrido libre -aunque sutilmente dirigido con objeto de conseguir la eficacia de nuestros objetivos- cierra el capítulo de caracterización discursiva del centro de interpretación que proyectamos.

Para transmitir una concepción paralela a la de la estructura orgánica del Instituto Andaluz del Patrimonio Histórico, el discurso del centro de interpretación de la institución debe sustentarse en varias disciplinas científicas, que a continuación enumeramos y en el siguiente capítulo pasamos a desarrollar:

\section{. Tutela del Patrimonio Histórico}

. Documentación

. Conservación/restauración

. Disciplinas afines a la conservación/restauración

modeio del LAPH. Así, la investigación, la documentación, la intervención, e incluso la difusión y la formación que se transmitan del Patrimonio Histórico Andaluz serán igualmente válidos para el Patrimonio Arqueológico Subacuático

${ }^{2}$ Ver apartado 3.5.1.1. 


\subsection{DOCUMENTACIÓN DISCIPLINAR: HISTORUA DE LA INVESTIGACIÓN Y ESTADO ACTUAL}

Seguidamente, hacemos un estudio en profundidad de la historia de la investigación y del estado actual de las tres disciplinas que, según hemos considerado, sustentan nuestro discurso.

\section{- TUTELA DEL PATRIMONIO HISTÓRICO}

Posterior a la disciplina vinculada a la conservación y restauración, pero en proceso de creciente consolidación, incluso en el ámbito académico y de la investigación, la disciplina que denominamos Tutela del Patrimonio Histórico es una realidad incontestable mucho más antigua que el término de reciente acuñación. El patrimonio y su tutela son hoy una simbiosis indisoluble que progresivamente va adquiriendo carácter científico ${ }^{3}$.

Las palabras de J. Castillo Ruiz nos revelan la existencia de esta nueva realidad disciplinar:

Un hecho incontestable en el momento presente es que la acción sobre los diferentes objetos que integran el Patrimonio Histórico dispone de unas bases cientficas, técnicas, teóricas y metodológicas que impiden considerarla como un complemento o una particular y específica ramificación de alguna o varias disciplinas como, por ejemplo, la Arquitectura, la Pintura o la Historia del Arte. Su cientificidad es evidente, como también lo es su constitución unitaria y homogénea, lo que nos permite considerarla como outéntica ciencia o disciplina autónoma. La difusa e insegura constitución de su aparato metodológico, consecuencia más de la adición inconexa de las aportaciones de las diversas ciencias que concurren -la interdisciplinariedad, oun siendo necesaria, no hace sino describir una situación, no la define-, que hoy presenta el ámbito de la acción patrimonial no invalida esa indiscutible premisa: la singularidad de la tutela como ámbito disciplinar (CASTLLO RUZ, 1998:72 y ss.)

\footnotetext{
${ }^{3}$ Numerosas universidades españolas y extranjeras otorgan titulaciones en gestión o tutela del Patrimonio Histórico, e innumerables másters o cursos de posgrado en la formación de esta disciplina se organizan por las instituciones académicas de todo el mundo
} 
Pero ¿para qué necesitamos la tutela del Patrimonio? ¿qué provecho nos revierte y qué utilidad tiene para el propio patrimonio? ¿qué diferencias existen entre tutela y gestión del Patrimonio?

La tutela y la gestión del patrimonio son conceptos aglutinadores que abarcan de uno u otro modo cualquier otra disciplina que se acerque al Patrimonio. Ahora bien, mientras que la tutela del Patrimonio Histórico es la disciplina cuyo objeto es el proceso completo de lo que denominamos ciclo de la tutela ${ }^{3}$, la gestión del Patrimonio Histórico tiene 'como objeto el estudio y desartollo de técnicas y estrategias, para facilitar la toma de decisiones que conducen al cumplimiento de unos objetivos concretos respecto de la función que debe cumplir el patrimonio histórico o los bienes culturales. La gestión, pues, deriva de la tutela, pero no equivale a ella; de ahí que prefuramos la denominación Tutela del Patrimonio Histórico.

La tutela del Patrimonio trata de dirigir los recursos hacia la consecución de unas determinadas y previstas metas, hacia la consecución de unos objetivos controlados. Su base de futuro es la investigación, e investigar representa el desarrollo de programas y el mantenimiento de una permanente actualización del pensamiento patrimonial, la integración de políticas y de agentes. La búsqueda de nuevas vías de avance, así como la renovación de los conceptos valorativos que acrecienten el patrimonio histórico y cultural, mediante el análisis, la incorporación de nuevas formas de cultura e innovación son tareas implicadas en la investigación patrimonial, una investigación que lleva consigo conceptos clave -transferencia, cooperación...- en la evolución de una institución.

Finalmente, hay que hacer hincapié en cómo la tutela del Patrimonio se encuentra ligada a la formación del ciudadano. Bosco Gallardo, hablando del patrimonio artístico contemporáneo, así lo entiende:

La acción tutelar implica una serie de momentos o funciones pero ninguno de ellos resulta viable si no existe una idea clara, un reconocimiento a priori con el que puedan desplegarse esas acciones. Aunque es obvio, conviene que nos planteemos seriamente que para tutelar algo se necesita un bien con un reconocimiento de necesitar o merecerlo. Si no queremos caer en un altruismo despótico, en la soberbia de velor por una riqueza perteneciente a la colectividad pero que ésta "por su minoria mental de edad" desconoce, es imprescindible promocionar el arte del siglo $X X$ a través del cada vez mayor periodo legal obligatorio de formación del ciudadano (GALLARDO, 1999)

\section{- DOCUMENTACIÓN}

\footnotetext{
${ }^{4}$ Protección - Investigación - Conservación - Documentación - Difusión - Protección
} 
Según la norma UNE 50113-1 (ARNOR, 1997) la Documentación como ciencia "se ocupa del estudio de las funciones, la estructura y la transmisión de la información, así como de la gestión de los sistemas de información. La Documentación como técnica se ocupará de la recogida y tratamiento de información registrada, de forma continua y sistemática y que permita su almacenamiento, recuperación, utilización $y$ transmisión"(GÓMEZ FERNÁNDEZ-CABRERA, 1999:159).

Las tres fases del proceso documental -investigación, sistematización y difusión- se aplican tambiér en el ámbito patrimonial, generando un sistema de información, es decir, un instrumento para la Gestión de la Información, proceso éste que "tiene su origen en los años 80 en los EEUU; su fin es posibilitar que las organizaciones consigan sus objetivos mediante la correcta estructuración y gestión de su flujos de información. Esta disciplina parte de la base de que la información es un recurso muy valioso que gestiona con criterios de economía y eficacia" (MUÑOZ, 1998:175).

La documentación del patrimonio puede entenderse aplicada a un bien cultural, a la actividad toda de un centro de documentación o bien enmarcada dentro de un sistema regional de información, peto la verdad es que se tiene que desarrollar a través de una praxis operativa que vaya cualificando ese proceso de conocimiento. Conocimiento que no es algo exclusivo de una parcela disciplinar, de un área de gestión o de una determinada comunidad científica, ya que desde distintos frentes de estudio y de acción se está contribuyendo al conocimiento del patrimonio (LADRÓN DE GUEVARA, 1996:104).

Servicio e instrumento, la documentación aplica actualmente las últimas tecnologías y crea sus propios modelos con el fin de contribuir al conocimiento. La reciente implantación de los estudios universitarios en Documentación ha supuesto un hito en la profesión, el reconocimiento de la existencia de una base científica de la disciplina (GÓMEZ FERNÁNDEZ-CABRERA, 1999:168). Estos estudios se estructuran en la actualidad en tres niveles: 1) estudios de primer ciclo (Titulación en Biblioteconomía y Documentación), 2) más recientemente, estudios de segundo ciclo (Licenciatura en Documentación) y 3) estudios de tercer ciclo y posgrado, que constituyen la oferta más variada y diversa.

\section{- CONSERVACIÓN/RESTAURACIÓN}

Más consolidada en el ámbito académico ${ }^{5}$, la disciplina conservación/restauración constituye una disciplina también más consolidada en el tiempo. Si bien las prácticas de intervención en obras de arte se remontan a la antiguedad histórica, la disciplina que las engloba científica y académicamente empieza a conformarse en el siglo XVII, y no es hasta el XIX -y sobre todo el XX- cuando prospera gracias a los avances científicos primero $\mathrm{y}$, posteriormente, técnicos.

\footnotetext{
${ }^{5}$ Las Facultades de Bellas Artes de nuestro país llevan aroos impartiendo especializaciones en Restauración, al igual que las más recientes Escuelas de Arte
} 
Por supuesto la historia de la investigación en conservación y restauración se ha ido transformando, y los criterios, metodologías, recursos y resultados han mejorado. El propio concepto también ha cambiado con la evolución de la disciplina $a^{6}$ : la utilización de intervención es relativamente reciente, parte del término acuñado por Solá-Morales y "recoge, y a la vez intenta superar, otros como conservación, restauración, rehabilitación, restitución, etc., conceptos tradicionales y contenidos formulados en las diferentes teorías de la restauración existentes. Todos estos conceptos tienen que ver con una manera concreta, y en una época determinada, de entender la acción sobre el objeto bien de interés cultural"(PÉREZ DEL CAMPO, 1996:47 y ss.).

En tiempos pasados el conocimiento de las obras artísticas se enfocó desde planteamientos histórico-artísticos, mientras que las intervenciones sobre las mismas, con objeto de restaurarlas, se han basado tradicionalmente en criterios tecnológicos empíricos (www.iaph.junta-andalucia.es). Sin embargo, en nuestros días, con el extraordinario desarrollo que las ciencias han alcanzado, mantener tales comportamientos no resulta aceptable ni oportuno.

La moderna ciencia de la intervención sobre los bienes culturales? es una disciplina con principios teóricos y metodológicos claramente establecidos. Su práctica exige que las decisiones estén precedidas y basadas en la identificación de su materialidad física y en la determinación de sus valores estéticos, históricos y documentales. Las decisiones deben estar fundamentadas en evidencias y conocimientos firmes y jamás en suposiciones.

En la actual disciplina, la colaboración entre el cientifico, el historiador y el restaurador es la esencia del éxito. De ahí, la necesidad de contar con profesionales de disciplinas y técnicas auxiliares a la conservación/restauración. A continuación se detallan las más relevantes.

\section{- HISTORIa}

La acción sobre el bien histórico, artístico, arqueológico, arquitectónico se enuncia desde unas bases conceptuales muy en consonancia con el pensamiento y filosofia estética del momento, pero con la cautela del rigor histórico; es decir, formulando la acción desde unas bases y estudios -de carácter científico- que nos den la mayor seguridad posible de planteamientos, sobre los que la acción pueda ser respetuosa a la vez que libre.

\footnotetext{
${ }^{6}$ Para profundizar en cuestiones de terminología entre conservación y restauración, repasar DE GUICHEN, 1999:4 Y ALONSO FERNÁNDEZ, 1996

${ }^{7}$ Para la mayor parte de la redacción de este apartado referido a la metodología modema de la Intervención nos hemos basado en la metodologia utilizada por el Instituto Andaluz del Patrimonio Histórico, descrita en PÉrEZ DEL CAMPO, 1996
} 
Ahora bien, en contraposición a aquellos momentos donde se estudiaban proyectos estereotipados sobre los objetos, en un intento de negar la creación, nuestra época reconoce la diversidad y que las adherencias de la historia o las interpretaciones -en el estudio y en la acción- deben tenerse en cuenta; por ello, no habrá dos proyectos idénticos. Esta y otras consideraciones dan relevancia al estudio y práctica de la metodologia como hilo conductor de las distintas variables del estudio del objeto y su contexto.

El conocimientó completo del bien exige, en primer lugar, una investigación histórica que nos permita documentar y tomar en consideración los distintos valores que pueden tener incidencia en las decisiones acerca de la conservación. Según José María Losada (1999:69 y ss.), los valores que se deben tener en cuenta en la investigación aplicada a toda intervención se pueden agrupar en dos grandes epígrafes, valores culturales y valores sociales:

\section{Valores culturales}

- Valor de identidad. Relacionado con los lazos emocionales de la sociedad hacia objetos y sitios específicos. Pueden incluir las siguientes caracteristicas: edad, tradición, continuidad, conmemoración, leyenda; o bien, vínculos sentimentales, espirituales o religiosos. Pueden también ser simbólicos, patrióticos o nacionalistas. Son valores de gran impacto en la salvaguarda, conservación o restauración de un bien.

- Valor técnico o artístico relativo. Se basa en evaluaciones científicas e histórico críticas, así como en la determinación de la importancia del diseño del bien cultural y la relevancia de su concepción y factura en términos técnicos, estructurales y funcionales. Proporcionan una estrategia para el tratamiento.

- Valor de originalidad. Procede de relacionar el bien cultural con otros del mismo tipo, estilo, autor, periodo, región o combinación de ellos.

\section{Valores socioeconómicos}

- Valor económico. Valor generado por el bien, o por la propia acción de conservación. Los valores económicos pueden identificar cuatro posibles fuentes de ingreso: el turismo, el comercio, el uso o las atracciones en el sitio. Al ser recursos no renovables, debe exigirse una gestión muy cuidadosa de los bienes.

- Valor funcional. Relacionado con el valor económico en tanto que supone la continuidad del tipo original de función del bien, o el inicio de un uso compatible de un bien o de un sitio determinado.

- Valor educativo. Incluye tanto su potencial para el turismo cultural como la concienciación sobre la cultura y la historia, como medio para integrar los bienes históricos en el presente. 
- Valor social. Se relaciona con las actividades sociales tradicionales, y con el uso compatible actual. Son valores que pueden generar la preocupación por el entorno local.

- Valor politico. Generalmente está relacionado con circunstancias específicas en la historia del bien, asociados a su vez con la región o el país. La relevancia actual del bien puede estar influenciada por estas circunstancias.

Por otro lado, las aportaciones de las ciencias experimentales y sus metodologias a la conservación de las obras de arte son fundamentales y están absolutamente recomendadas por las organizaciones e instituciones internacionales de mayor relieve en el campo de la conservación de los bienes culturales -UNESCO, CIM, COIML, IIC... (www.iaph.junta-andalucia.es).

- FISICA

La primera de las disciplinas científicas auxiliares a la intervención que vamos a desarrollar es la ciencia fisica. En numerosas ocasiones actuar sobre el patrimonio sin conocer su composición material, los agentes de alteración extrínsecos e intrínsecos que actúan sobre él y las caracteristicas del medio en el que se encuentra ha conducido a alteraciones más graves que las iniciales o, en el mejor de los casos, no ha producido ninguna mejora en el estado de las obras. Igual consideración se puede hacer sobre los productos de tratamiento; si no se realizan ensayos para evaluar su posible comportamiento previamente a su aplicación a la obra, puede llegarse a provocar alteraciones mayores que las existentes previamente. Las ciencias fisicas son esenciales en los siguientes cometidos:

- Conocimiento de la estructura material de las obras, para lo cual es necesario determinar la composición química, las características fisicas y mecánicas de los materiales de que se compone, así como la estructura formal de la misma. En ocasiones será necesario determinar la procedencia de los materiales y su datación.

- Estudio del medio ambiente que rodea la obra, determinando el microclima adyacente (tanto interno como externo), la posible contaminación atmosférica, las características geológicas e hidrogeológicas del terreno, etc.

- Estudio del estado de conservación, analizando los productos formados como consecuencia de la alteración sufrida por la obra. Este dato junto con las características del medio permite definir los posibles agentes de alteración (químicos, fisicos, mecánicos, biológicos) que actúan sobre las obras, realizando ensayos de deterioro acelerado en el laboratorio en caso necesario.

- Evaluación de los productos, materiales y técnicas empleados en restauración: compatibilidad con los materiales originales y efecto sobre las características de las 
obras, comportamiento frente a los agentes de alteración a que se encontrará sometida la obra restaurada.

- QUIMICA

Las aplicaciones de otra disciplina, la química, a la conservación de obras de arte forma parte igualmente de la concepción modema de la conservación-restauración. Entre las aportaciones de la disciplina quimica destacan:

- Análisis cuantitativo instrumental de muestras inorgánicas mediante espectrometria de absorción atómica y mediante espectrometria Un-Vis

- Microscopia electrónica con microonda de Rayos-X

- Análisis cuantitativo y semicuantitativo instrumental de muestras inorgánicas mediante difracción de Rayos-X, espectroscopia FTIR y microscopia electrónica SEM-EDX

- Análisis químico por vía húmeda de materiales de construcción y material cerámico

- Microscopia óptica de láminas delgadas de materiales de construcción y cerámicos

- Estudio petrográfico y mineralógico por difracción de Rayos-X

- Microscopia óptica de muestras de estratigrafia e identificación cualitativa de pigmentos, cargas y aglutinantes en muestras de pintura y escultura

- Análisis cualitativo instrumental de componentes orgánicos de películas pictóricas, mediante cromatografia gaseosa, espectroscopia FTIR y cromatografia HPLC

- Microscopia óptica de tejidos para la identificación de fibras

- Identificación de tintes y colorantes en tejidos mediante cromatografia HPLC y cromatografia en capa fina

- Caracterización de hilos y elementos metálicos en tejidos por SEM-EDX

- Estudios metalográficos mediante microscopia óptica

- BIOLOGÍA

También la biología colabora en el trabajo multidisciplinar de la intervención. La biologia en la restauración se dedica a estudiar los "problemas ligados al biodeterioro de las obras de arte, entendiendo por biodeterioro un cambio no deseado de las propiedades de sus materiales, debido a la actividad de microorganismos u organismos pertenecientes a distintos grupos sistemáticos". Aunque "su campo de interés es vastísimo y multidisciplinario", el estudio de la biología aplicada a la restauración es relativamente reciente (CANEVA, G., NUGARY, M.P. y SALVADORI, O., 2000:11).

Así, un nuevo paso en el proceso de intervención será la identificación de los agentes que pueden causar el deterioro del patrimonio cultural, pues su conocimiento permitirá diseñar una adecuada estrategia de control del posible deterioro y la planificación de las altemativas de conservación. Para que el control del deterioro sea efectivo se han de planificar una serie de etapas sucesivas, claramente diferenciadas, que nos permiten 
identificar las distintas situaciones y actuar en consecuencia: evitar, bloquear, detectar, actuar, recuperar.

Evitar el agente resultará siempre lo más rentable. Ahorraremos tiempo y dinero. Estamos hablando de conservación preventiva. Como evitar todos los agentes de deterioro, en la práctica, resulta imposible, debemos disponer lo necesario para bloquear su actuación, de modo que, aún estando presente, no produzca efectos indeseables. Seguimos en el terreno de la conservación preventiva. Como puede suceder que alguno de los agentes supere estas primeras etapas de control, debemos establecer los medios necesarios para detectar que un agente determinado está actuando. La detección es ya, en el fondo, una admisión de pesimismo, pero es realista. Todavia es conservación preventiva. Cuando se ha detectado la actividad de cualquier agente de deterioro se debe responder, y responder además muy rápidamente, con el fin de minimizar los posibles daños al máximo. Entrariamos en el terreno de la conservación activa, en la adopción de medidas correctoras en el entorno del bien en peligro. Cuando todo ha fracasado, entonces hay que recuperar, hay que solucionar el desastre siempre que ello sea posible. La recuperación es la etapa tradicional de la restauración que, desde una concepción integral y responsable de la conservación preventiva, es el reconocimiento de una fracaso que resulta, en ocasiones, inevitable (LOSADA, 1999:69 y ss.).

La biologia realiza todos los ensayos y análisis relacionados con la alteración biológica de los materiales y obras constitutivos del patrimonio histórico, como por ejemplo:

- Análisis microbiológico mediante cultivos y/o microscopia óptica

- Identificación de insectos

- Análisis de líquenes, identificándolos mediante microscopia óptica y estudiando el efecto sobre el soporte por SEM-EDX

- Análisis de otros agentes biológicos (plantas, musgos, algas...)

- Identificación de maderas

- Evaluación de las técnicas y productos para eliminar organismos causantes de deterioros

- Evaluación de la compatibilidad de las técnicas y productos para eliminar organismos en relación con los materiales constitutivos de las obras de arte o de los productos empleados en la restauración

- Desinsectación de obras de arte con gases inertes

- FOTOGRAFIA

Finalmente, la técnica fotográfica es practicada como medio de control de las restauraciones y como documento científico. La aplicación de la fotografia al examen científico de obras de arte permite obtener documentos permanentes de las diversas etapas del tratamiento, incluidos los estados inicial y final, y la imagen visible 
necesaria para comparar con otros documentos, con vistas a la interpretación de los datos obtenidos por los distintos métodos de análisis.

Trabajos en blanco y negro, gran formato, color y transparencias formato $35 \mathrm{~m} / \mathrm{m}$ se aplican al análisis y restauración del patrimonio histórico, al igual que la fotomicrografia, fotomicrografia, luz rasante, luz ultravioleta y luz infrarroja. El servicio de reflectrografia infrarroja es fundamental en la aplicación básica en el estudio del dibujo subyacente, mientras que la radiografia tiene muchas y variadas aplicaciones en el examen interno o en profundidad de obras de arte, fundamentalmente para la determinación del estado material del bien, amplitud de alteraciones, intervenciones, etc. y del soporte, preparación y capa pictórica.

Por último, antes de acabar este apartado y una vez conocida -muy someramente- la trayectoria histórica y el estado actual de las disciplinas que sustentan nuestro discurso, concluimos con unas breves referencias bibliográficas de cada una de ellas.

Para el estudio de la tutela del Patrimonio Histórico se puede consultar el Manual of Heritage Management, de Richard Harrison. En cuestiones documentales es útil la monografia de E. Currás Las ciencias de la documentación: bibliotecología, archivologia, documentación $e$ información, mientras que para cuestiones de investigación histórica se puede retomar el artículo de José María Losada "Teoría y praxis de la conservación: el rol del historiador del arte". Finalmente las ciencias aplicadas cuentan con amplia bibliografia -como se refleja en el último capítulo del proyecto-, de la que destacan Ciencia y restauración y La biologia en la restauración. 


\subsection{CONCLUSIONES Y PRINCIPIOS QUE PRETENDEN SER EXPLICADOS}

¿Cuáles son los, principios que van a ser transmitidos, en última instancia, en nuestro centro de interpretación? ¿Cuáles son las ideas ineludibles y fundamentales, las claves de interpretación de nuestro centro de visitantes?

Para dar respuesta a estas cuestiones, establecemos una distinción entre principios ideológicos de la institución, es decir, cuestiones de fondo que sustentan el LAPH, y principios o conclusiones más o menos científicas que tienen que ver con las disciplinas que se desarrollan en el Instituto.

En el primer apartado, principios ideológicos de la institución, destacamos los siguientes principios:

- Investigación y desarrollo: como institución I + D, el Instituto Andaluz del Patrimonio Histórico dedica parte de sus esfuerzos a las actividades de investigación, inscritas siempre dentro de los siguientes marcos: V programa marco de la Unión Europea (1998-2000), Plan Nacional de Investigación Científica, Desarrollo e Innovación Tecnológica, Plan Andaluz de Investigación y Plan General de Bienes Culturales (Consejería de Cultura. Junta de Andalucía). La proyección investigadora del centro le lleva a formular y importantes proyectos de investigación propios y en colaboración con otras instituciones científicas nacionales y extranjeras.

- Modelización: El Instituto Andaluz del Patrimonio Histónico es una institución que no se repite clónicamente, en el resto de la estructura, como ocurre con otros servicios, sino que busca rentabilizar al máximo su papel singular y de apoyo al resto de los agentes, siguiendo el esquema conceptual extendido en las grandes empresas con servicios cualificados, de apoyo a toda la organización (Concepto, funciones y servicios. Función social y propuesta de planificación del Instituto Andaluz del Patrimonio Histórico. Informe para la V Legislatura). El LAPH es un órgano de intermediación entre distintos organismos e instituciones públicas y privadas que debe ser modelo de actuación. Asimismo, se trata de un órgano de asistencia y consulta, que resuelva o canalice problemas en el campo del Patrimonio Histórico. En un plano más concreto, el corpus de intervenciones y productos que se desarrollan en el LAPH tienen la intención de facilitar a los profesionales de la conservación y restauración, de la documentación y difusión, de la gestión de los bienes culturales una herramienta útil y modélica en el ejercicio de su actividad. 
- Interdisciplinariedad: una red de profesionales de múltiples disciplinas y todos ellos trabajando en comunión e interfiriendo, enriqueciendo sus tareas es una de los principios inherentes al IAPH.

- Transferencia: todo valor producido por la institución es traspasado de algún modo a la sociedad, quien, a su vez, va marcando el ritmo y magnitud de lo transmitido.

- Formación', en cuanto a la necesidad de construir y formar a nuestros profesionales en un lenguaje común de los bienes culturales y su actividad tutelar, el desarrollo de un mayor nivel de especialización del personal propio y la cualificación de los profesionales vinculados al Patrimonio (Concepto, funciones y servicios...).

- Sensibilización. La relación mediadora entre el IAPH y la sociedad pasa por la difusión del Patrimonio Histórico desde una perspectiva sensibilizadora, que repercuta en la protección, conservación y correcta valoración de dicho patrimonio. Más allá de la transmisión de conocimientos e informaciones, la sensibilización es la misión de la comunicación.

- Intercambio: el fomento del debate interinstitucional y de los distintos agentes que componen el panorama del Patrimonio, del intercambio de experiencias entre los distintos profesionales y centros de trabajo con el fin de implementar esfuerzos y aunar criterios de actuación es otra de las misiones originarias de la institución (Concepto, funciones y servicios...)

- Tecnología aplicada: una de las misiones de la institución es el desarrollo de nuevas tecnologías en el campo patrimonial, tanto para la conservación como para la documentación.

Dentro del grupo relacionado con las disciplinas que sustentan nuestro discurso, encontramos los siguientes principios científicos que, en el centro de interpretación, tendrán que reflejarse y explicarse, si no explícitamente, de un modo tácito, algunas veces casi subliminal:

a) En cuanto a la disciplina Tutela del Patrimonio Histórico, hallamos estas claves de interpretación:

- Función social: en el IAPH toda actividad lleva inherente su finalidad social, el acercamiento del Patrimonio a la sociedad.

- Metodología: Atender a las exigencias de desarrollo y puesta al día de los criterios y metodología en los que basar el amplio campo de la tutela del Patrimonio Histórico era una de las necesidades que recogía el Programa Especial para la 
planificación del IAPH. En la actualidad, y específicamente, los Centros de Documentación e Intervención han desarrollado una metodología de trabajo unificada y homogénea que representa uno de los grandes logros de la institución.

b) La disciplina Documentación establece estas conclusiones científicas:

- Gestión del conocimiento: El mantenimiento del legado patrimonial implica previamenté un acto de conocimiento. Debemos saber dónde se localiza el bien, de qué se compone, qué problemas tiene, etc., acto que, en primera instancia, podríamos denominar de clasificación del bien cultural.

- Integración: un sistema integrado, interrelacionado es mucho más que un conjunto de bases de datos. Este principio del SIPHA es una de las claves documentales que se defienden en la institución.

- Difusión: la transmisión al usuario del sistema de información es el enriquecimiento de la gestión del conocimiento, del tratamiento informático y documental de la información. La difusión de la información es el servicio del producto informativo ágilmente previa consulta de los usuarios de los bienes culturales (Concepto, funciones y servicios...).

- Normalización: llamar a las cosas por su nombre, y llamarlas todos de la misma manera es una de las luchas de la documentación. En el Instituto Andaluz del Patrimonio Histórico, el SIPHA tiene un lenguaje común normalizado que es el Tesauro del Patrimonio Histórico, que garantiza la relación interna, junto a un estricto sistema de codificación.

c) La disciplina Conservación/restauración integra:

- Intervención: actuación directa destinada a recuperar un estado histórico o estético de un elemento del patrimonio que está dañado (DE GUICHEN, 2001).

- Conservación: actuación directa o indirecta destinada a aumentar la esperanza de vida de uno o varios elementos del patrimonio que están sanos -conservación preventiva- o en deterioro activo -conservación curativa- (DE GUICHEN, 2001).

- Investigación aplicada: concepto relacionado con la obligación de desarrollar una labor de investigación científica y documental, o, lo que es lo mismo, conocer la naturaleza fisica y las fuentes históricas antes de la intervención y documentar el proceso para el futuro (LOSADA, 1999:69-70).

- Valoración del bien cultural dando su justa estimación histórica, artística y social previa investigación. 
- Valor añadido, en el sentido histórico, es decir, reconocer la obra como sedimento fisico acumulativo de la actividad humana, lo que engloba valores culturales, materiales y técnicos (LOSADA, 1999).

- Mínima intervención, restableciendo la legibilidad estructural, estética y semiótica con la menor interferencia (LOSADA, 1999).

- Legibilidad, a través de claves para facilitar la lectura, la apreciación del bien.

- Integración, ofreciendo una unidad visual de la obra sin obstáculos que impidan su correcta percepción y contemplación.

- Reversibilidad, obligación de realizar intervenciones que permitan otras opciones y tratamientos posibles en el futuro, esto es, aplicar procedimientos que hagan posible un nuevo tratamiento, cuando nuevos materiales y técnicas lo hagan aconsejable (LOSADA, 1999).

- Autenticidad, respeto histórico, mantenimiento del original.

- Identificabilidad de la intervención, identificación respecto del original.

- Carácter cientifico: El IAPH ha venido trabajando para la formulación de un instrumento que permita sistematizar y poner a disposición de los agentes y profesionales de la restauración un conjunto de recursos y prestaciones científicas de elevado nivel y calificación técnica en materia de ciencias y técnicas aplicadas a la conservación del patrimonio histórico. Este instrumento es el Programa de Servicios para la Intervención en el Patrimonio Histórico. En concreto, el IAPH ofrece diferentes técnicas, análisis, ensayos, proyectos e informes a los investigadores, a los restauradores y a los Conservadores del Patrimonio Histórico. La actualización y garantía de los trabajos está garantizada por la conexión de los diferentes laboratorios y talleres con el mundo de la investigación universitaria y con el Consejo Superior de Investigaciones Cientificas.

- Alteraciones, patologias que sufre una obra debido a la acción de los agentes de degradación.

d) Finalmente, en cuanto a las disciplinas afines a la conservación, destacamos estos principios científicos:

- Análisis, examen científico para conseguir un mejor conocimiento de los bienes culturales, así como de las técnicas y productos de tratamiento, con el fin de acometer las intervenciones sobre los mismos en las mejores condiciones posibles.

- Diagnosis: definición y establecimiento de las alteraciones con el fin de realizar una propuesta de tratamiento. 


\subsection{TEMA PRINCIPAL Y SUBTEMAS. ORGANIZACIÓN Y SECUENCIACIÓN}

De acuerdo con,el discurso básico que rige el centro de visitantes, apoyándonos en las disciplinas científicas que lo respaldan y en las conclusiones o claves más o menos científicas que han de ser transmitidas, establecemos la siguiente secuencia de temas, organizados del modo que sigue en función de su importancia y eficacia comunicativa:

\section{El LAPH y su filosofía}

Este primer módulo afrontará el tema principal y, además de contestar a las preguntas ¿Qué es un Instituto de Patrimonio? y ¿Qué es la tutela del Patrimonio?, hará frente a los principios clave del IAPH y de la tutela patrimonial que se han explicitado en el apartado 2.3., a saber: la investigación y desarrollo, la experiencia modélica, la interdisciplinariedad, la vocación de transferencia y función social, la sensibilización y la construcción de una metodología.

\section{La estructura del IAPH}

En un segundo bloque, se intentará contestar a la pregunta ¿Cuál es la estructura que avala y responde a las competencias concedidas al IAPH? Para ello, se establecerá una secuencia de subtemas organizada de este modo:

\section{a) Los dos núcleos básicos:}

\section{. El Centro de Intervención}

Estructurado en tres apartados básicamente: la función de la investigación, la función de los laboratorios de análisis -fotografia y radiografia, geologia y ensayo de materiales, química, biologia y paleobiologia-, y la actuación de los talleres de restauración (tejidos, escultura, pintura, patrimonio documental y gráfico, material arqueológico e inmuebles).

Asimismo, este núcleo abarcará paralelamente las conclusiones o principios científicos de la intervención que se han definido con anterioridad.

\section{. El Centro de Documentación}

Se podrá ordenar en cuatro apartados principales: la gestión de la información como gestión del conocimiento -que podrá incluir información relativa a la estructura por departamentos (Departamento de Desarrollo de la Información, Departamento de Técnicas Gráficas e Informáticas y 
Servicio de Información), el Sistema de Información del Patrimonio Histórico de Andalucía /SIPHA (filosofia, contenidos y bases de datos), los servicios del centro - concretados en el Servicio de Demandas Puntuales y la biblioteca- y los productos de información -especialmente referidos a productos en internet.

b) Los elementos transversales:

\section{. La formación}

El apartado temático relativo a la formación de profesionales en la tutela, conservación, documentación y difusión del patrimonio histórico se centrará en la presentación de las líneas preferentes de actuación del Departamento de Formación, que se corresponden con las unidades de discurso; a saber, programa de posgrados, programa de cursos de especialización y programa de becas. Se transmitirá además la idea del patrimonio como recurso educativo, científico, de creación cultural, económico, de identidad, cohesión social y participación ciudadana donde confluyen las diversas disciplinas académicas, colectivos profesionales, instituciones, asociaciones y organizaciones ciudadanas, con el fin común de favorecer el desarrollo social y perpetuar la memoria para el futuro (10 años para innovar desde la memoria, 2000).

\section{. La difusión}

Las unidades discursivas del apartado de Comunicación serán la línea de publicaciones que lleva adelante el Departamento (concretada en $P H$. Boletín del Instituto Andaluz del Patrimonio Histórico y las colecciones Cuadernos y Cuadernos Técnicos), las actividades de difusión de la institución (exposiciones y jornadas o seminarios) y el sistema de visitas especializadas al IAPH (dentro del cual se establece el centro de interpretación en el que se encuentra el visitante). Este elemento temático tendrá que transmitir también su vocación de gestión mediadora entre el Patrimonio/la institución y la Sociedad, y el requerimiento, para su correcta consecución, de un entramado de agentes (escuela, oficina de turismo, etc.) en el que el IAPH se engarza.

\footnotetext{
${ }^{8}$ ver apartado 1.1.2.
} 


\section{CONTENEDOR}




\subsection{SITUACIÓN. ESTUDIO DE VENTAJAS E INCONVENIENTES}

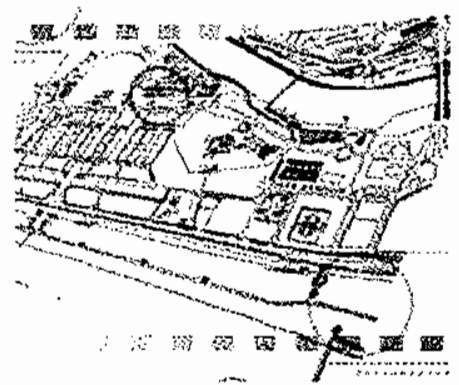

Ubicado en el corazón de la Isla de la Cartuja, a orillas del Guadalquivir a su paso por la ciudad de Sevilla, el Instituto Andaluz del Patrimonio Histórico dispone de una extraordinaria sede surgida del esfuerzo realizado por la administración andaluza en el antiguo monasterio de La Cartuja de Santa María de las Cuevas para la Exposición Universal de 1992. Completamente restaurado y rehabilitado en sus edificaciones, jardines y huertas, que ocupan un área de 12 hectáreas con más de 35.000 metros cuadrados edificados, La Cartuja es hoy un espacio de arte y cultura, sede de instituciones tan relevantes como la Universidad Internacional de Andalucía, el Centro Andaluz de Arte Contemporáneo y el Instituto Andaluz del Patrimonio Histórico.

En el siguiente plano se observa cómo la sede del LAPH está enclavada en un entorno urbano destinado al ocio y la cultura, al desarrollo científico y la investigación' ${ }^{1}$ :

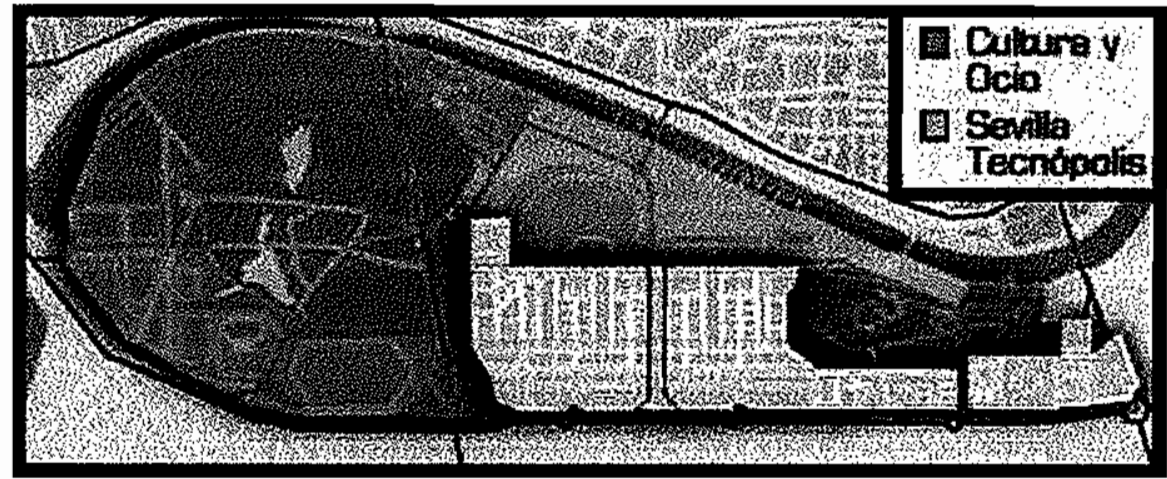

\footnotetext{
'Sevilla Tecnópolis es un Parque Científico y Tecnológico, nacido para contribuir a la investigación y el desarrollo
} 
Tras un largo proceso de rehabilitación, la que se conocía como "zona fabril» del monasterio, que fue anteriormente clausura de legos, marcada por su fisonomía de fäbrica y por la escasez de construcciones religiosas, acogió en 1990, provisionalmente, y desde 1992, de forma definitiva, el entonces nuevo Instituto Andaluz del Patrimonio Histórico. De este modo, la extraordinaria ventaja que presenta la situación del IAPH es su ubicación en un conjunto monumental, que comparte con instituciones de cultura de prestigio: Monasterio de Santa María de las Cuevas, Centro Andaluz de Arte Contemporáneo y Universidad Intemacional de Andalucía.

De otro lado, y en relación a la situación que ocupará el centro de interpretación en el espacio del Instituto Andaluz del Patrimonio Histórico, hay que anotar que la principal ventaja es que se halla en el espacio expositivo habitual del IAPH, en la llamada "zona de exposiciones". Esta continuación temática de la zona tiene la ventaja de ofrecer coherencia en la actividad y uso de espacios del IAPH, así como la de poner de manifiesto la intención de mejorar la oferta de difusión de la institución.

En otro sentido, el Centro de Interpretación se ubica en un espacio de grandes connotaciones históricas (el visitante puede observar in situ el resto de un homo almorávide del siglo XI, divisar chimeneas de homos de la fábrica Pickman del XIX y acceder a una celda de legos, además de contemplar la rehabilitación del edificio de 1992 durante prácticamente todo el recorrido de la visita). Esto supone, en efecto, una ventaja desde el punto de vista del contenido, pero también responde a un gran acierto en la elección del continente. 


\subsection{UBKCACIÓN. ESTUDIO DE ACCESIBILIDAD}

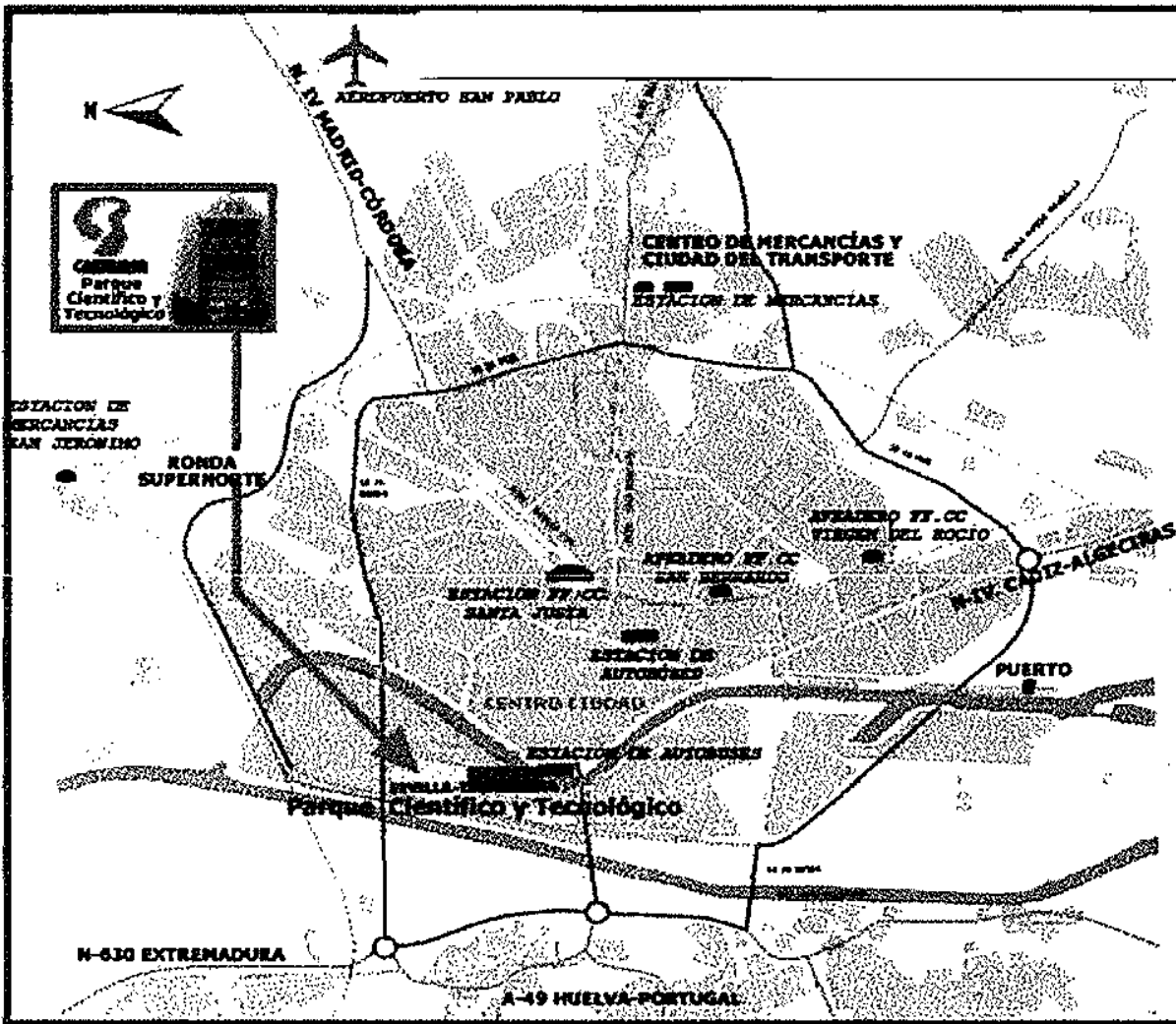

Monasterio / IAPH

Como se pone de manifiesto en el plano, la valoración de la accesibilidad a La Cartuja y, por ende, al Instituto Andaluz del Patrimonio Histórico es positiva. Lejos ha de quedar, en definitiva, esa percepción de La Cartuja distante, alejada, inaccesible que aún permanece en la mente del ciudadano.

La accesibilidad a La Cartuja por carretera es manifiesta, mediante rondas de circunvalación, SE-30, y varias autovías y carreteras nacionales (A-49 HuelvaPortugal, N-630 Extremadura, N-IV Madrid-Córdoba y Cádiz-Algeciras). Sumado a ello, se observa la cercanía de estaciones de autobús (Estación Plaza de Armas) y de tren (Estación Santa Justa), asi como la posibilidad de hacer el trayecto desde el centro 
de la ciudad a La Cartuja en unos quince minutos o de acceder en taxi o líneas de bus urbano (concretamente las lineas C1 y C2 tienen parada en el Monasterio).

Hay que destacar la progresiva puesta en valor de esta zona urbana del otro lado del río, gracias a la incorporación sin detenimiento e implantación de empresas, organismos públicos e instituciones de investigación y universitarias. Todo ello está favoreciendo la mejora de infraestructuras de accesibilidad y transporte, de la que, lógicamente, se beneficia el IAPH.

En cuanto a la ubicación del Centro de Interpretación en relación al espacio de la sede del Instituto Andaluz del Patrimonio Histórico, y su valoración de accesibilidad, concluimos también en positivo. La situación del centro de visitantes, justo a la entrada de la institución y en la parte inferior al área de Administración, le confiere el valor de zona independiente que la institución requiere para sus visitantes, a lo que hay que sumar la ventaja de contar con dos entradas principales alternables ${ }^{2}$ : a) la habitual de la institución, con la ventaja de ser plenamente identificable con el IAPH y b) la proyectada por Vázquez Consuegra como entrada principal, que tiene la ventaja de enlazar más directamente con el área del Monasterio y CAAC y de servir de acceso de flujos de visitantes independientemente del personal de la institución y por una vía de entrada exterior al núcleo de trabajo.

Este acceso, que da al hall de entrada de la institución (convertido ahora en lugar de distribución de flujos de público -y marcado en plano con $\mathrm{X}$ ) presenta el valor añadido de servir de enlace con otras zonas del centro de visitantes, como la zona de exposiciones temporales (en plano serialada con 1) y la zona de actividades didácticas (en plano ser̃alada con 2), cada una de ellas también con otras posibles vías de acceso o salida.

En el siguiente plano de la institución se observa la ubicación del centro de interpretación y su accesibilidad, tanto desde la Puerta de Tierra del Monasterio (acceso a sede Monasterio y CAAC) como la Puerta del Río (acceso a sede IAPH):

\footnotetext{
${ }^{2}$ Finalmente, como se leerá en el apartado 3.5., se ha decidido elegir la opción b) como entrada principal al centro de visitantes. No obstante, esto no significa que la existencia de otro posible acceso sea un elemento de provecho e importancia
} 


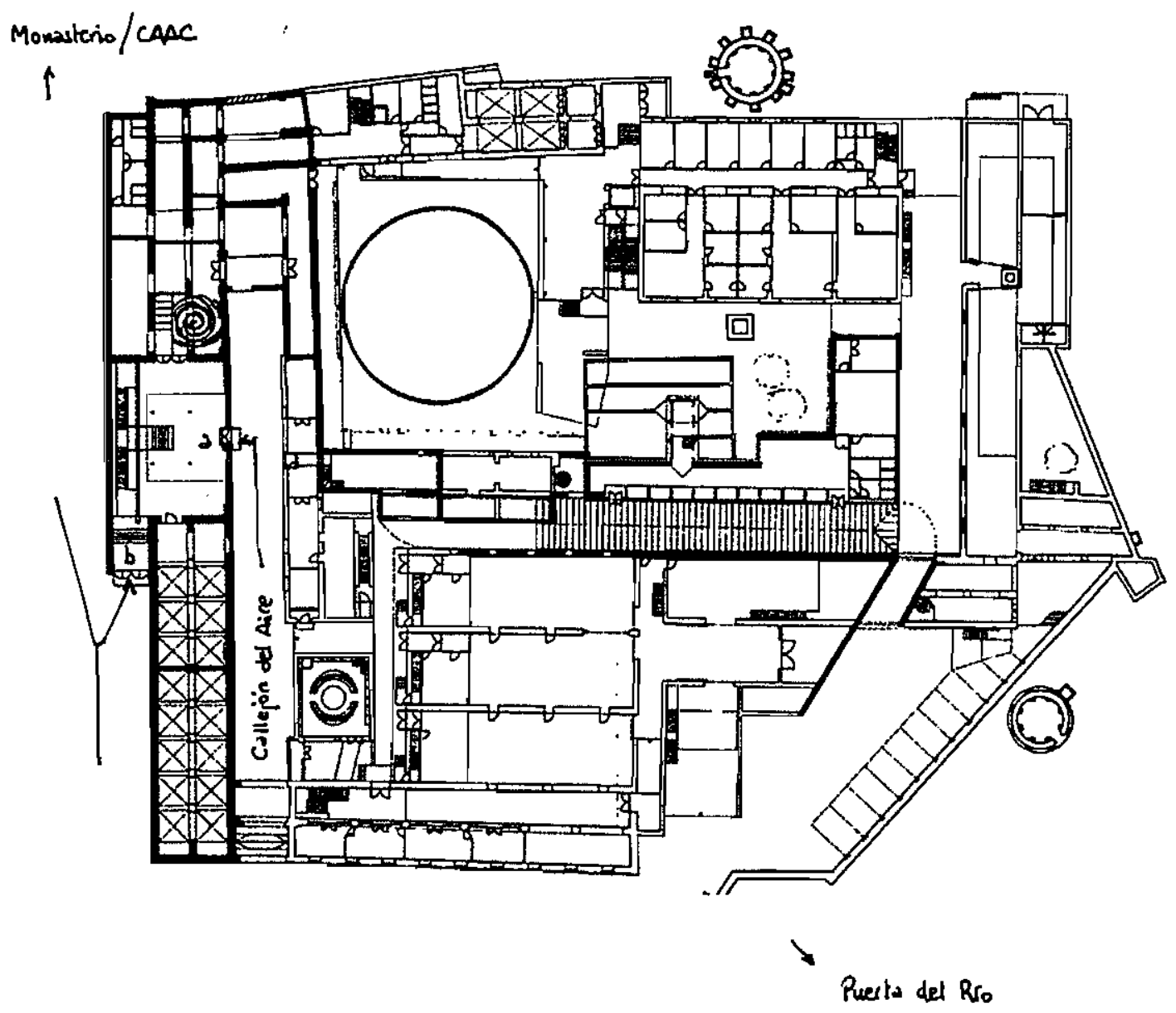




\subsection{SUPERFICIE MINIMA REQUERIDA}

La superficie minima requerida para realizar el Centro de Visitantes del IAPH se corresponde con la superficie coloreada en el plano que sigue, esto es, aproximadamente 1.500 metros cuadrados, repartidos en siete zonas, todas ellas construidas aunque con necesidad de ser ligeramente reformadas:

a. hall de entrada, espacio de distribución de flujos de público: aprox. 32 metros cuadrados

b. itinerario principal: aprox. 468 metros cuadrados

c. zona al aire libre dedicada al denominado Círculo del Patrimonio: aprox. 560 metros cuadrados

d. tienda-librería: aprox. 48 metros cuadrados

e. cafeteria: aprox. 130 metros cuadrados

f. zona de exposiciones temporales: aprox. 115 metros cuadrados

g. zona de actividades didácticas: aprox. 144 metros cuadrados 


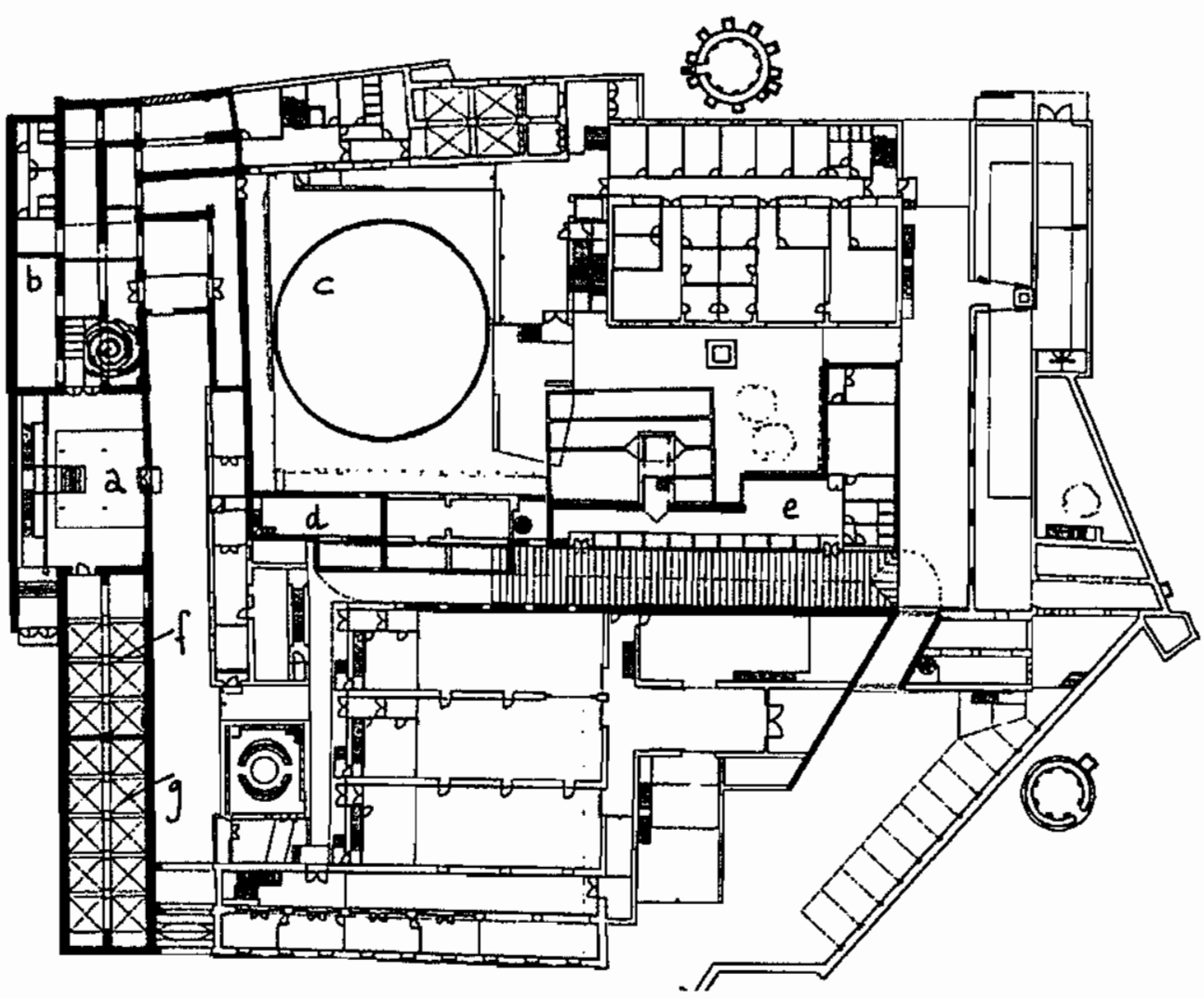




\subsection{CARACTERÍSTICAS ARQUITECTÓNICAS EXIGIBLES}

El edificio que va a albergar el Centro de Interpretación, como se ha visto en el apartado 3.3., cuenta con la superficie necesaria para establecer el recorrido propuesto, la instalación de arte contemporáneo, la tienda-librería y cafetería zona de exposiciones temporales y talleres didácticos, así como espacios cercanos para descansar.

Además de las dimensiones espaciales, el edificio cuenta con otras caracteristicas arquitectónicas que hubieran sido de exigir en cualquier caso:

\section{. RED ELÉCTRICA}

\section{. MUROS, SUELOS Y TECHOS NO IGNIFUGOS}

. PROTECCIÓN CONTRA INCENDIOS: El LAPH cuenta con una red de protección de alarmas con central de recepción y detectores iónicos. Durante todo el recorrido del centro de interpretación, en las salas de exposiciones y didáctica, en tienda y cafetería se reforzará el sistema de extinción manual.

- AUSENCIA DE BARRERAS ARQUITECTÓNICAS: Para las personas con discapacidades fisicas, especialmente para aquellos que utilizan sillas de ruedas, se procurará siempre que puedan desplazarse con facilidad por todo el recorrido. En cualquier caso, se seguirán las normas del Real Decreto 556/1989, de 19 de mayo, por el que se arbitran medidas mínimas sobre accesibilidad en los edificios, fundamentado en la Ley 13/1982, de 7 de abril, de Integración Social de los Minusválidos, que dispone que el arbitrio de medidas oportunas para evitar las barreras arquitectónicas, de forma que los edificios resulten accesibles y utilizables por personas con discapacidad motriz. De acuerdo con la Ley, el Centro de Interpretación cumple todos los supuestos y normas establecidas:

- La comunicación entre el interior y el exterior del edificio es factible para estas personas.

- Además, no se incluyen escaleras ni peldaños aislados. Aquí hay que destacar que todos los accesos y salidas del Centro de Interpretación están al nivel del suelo, a excepción de la salida al patio (instalación Círculo del Patrimonio) y entrada a la celda de legos (tienda-libreria), que serán superados, según marca la Ley, con

\footnotetext{
${ }^{3}$ Se trata de un recorrido en "L"; se sale al patio y se entra a la celda de legos a través de un itinerario en alto, a 0,50 metros desde el suelo, de modo que el visitante pueda percibir la
} 
rampas de una pendiente máxima del $8 \%$ (12\% si tienen menos de 3 metros). Las rampas y planos inclinados tendrán pavimento antideslizante y estarán dotados de los elementos de protección y ayuda necesarios, como por ejemplo pasamanos.

- Los itinerarios tienen una anchura libre minima de 0,80 metros y, en los cambios de dirección, los itinerarios disponen del espacio libre necesario para efectuar los giros con silla de ruedas. Las puertas y calles del recorrido son suficientemente anchas y cómodas de recorrer; únicamente la entrada a la celda de legos puede resultar pequeña, por lo que se habilitará una prolongación del recorrido ex profeso para las personas con discapacidad fisica (ver apartado 3.5.1.1.).

- Se habilitarán dos aseos, inexistentes en la actualidad, para personas con movilidad reducida en el recorrido, uno en las salas permanentes y otro en la cafetería (ver apartado 3.5.6.).

instalación de arte contemporáneo El Círculo del Patrimonio -que estará en la superficie del patio y será plana y horizontal- desde una posición elevada 


\subsection{DESCRIPCIÓN DE LOS ESPACIOS}

\subsubsection{SALAS DE EXPOSICIÓN PERMANENTE}

Como se ha podido comprobar con antelación, el centro de visitantes del Instituto Andaluz del Patrimonio Histórico no se reduce a una sala de paneles explicativos sobre la institución sino que pretende configurarse como un programa de difusión integral al público menos especializado que tiene la oportunidad o el deseo de conocer el LAPH. En esta línea, el centro de visitantes toma forma mediante la actividad conjunta de un centro de interpretación propiamente dicho o salas permanentes de explicación de la institución, una sala de exposiciones temporales, un área de talleres didácticos, una tienda-libreria y un espacio para cafeteria.

En cuanto a las salas destinadas al recorrido principal del Centro de Interpretación, objetivo de descripción de este apartado, se puede afirmar que mantienen la identidad de la actividad difusora y expositiva del Instituto Andaluz del Patrimonio Histórico, al situarse justamente en el espacio dedicado hasta la actualidad al montaje de unidades expositivas, esto es; en la planta baja del Área de Administración y de Régimen Interno. Se trata de una zona muy amplia y de gran atractivo espacial, por los restos de estructuras del siglo XIV que han sido acertadamente recuperados e integrados con la arquitectura más moderna de Vázquez Consuegra. Es un recinto, además, que cuenta con las condiciones arquitectónicas (red eléctrica, eliminación de barreras electrónicas, sistema de iluminación y de seguridad...) deseables, y que se adapta a las necesidades del Centro de Interpretación para cubrir sus necesidades a largo plazo.

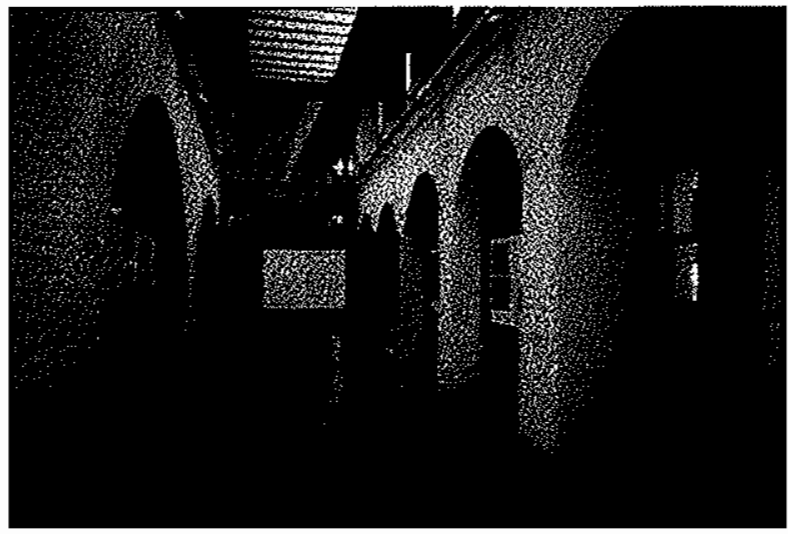


En el contenedor, en las salas de exposición permanente, se dan también unas condiciones adecuadas de contemplación y de comunicación, en consonancia con los requerimientos de J. Barbosa (1993):

Para que una exposición alcance sis fines, en primera instancia debe lograr que el visitante se sienta a gisto en el lugar. quiera contimuar viendo la exposición. En este sentido, tiente que ofrecer aislamiento, $\mathrm{m}$ espacio para contemplar, un lugar exento de distracciones

Por otro lado; intentaremos que la amplitud del espacio y el color del recinto se relacionan directamente, utilizando colores claros en los paneles de fondo que construyen el recorrido, cerrando con ellos los arcos existentes a nuestra conveniencia. De esta manera, al utilizar paneles claros, el espacio resultará mayor a la percepción del visitante. Estos paneles serán de $10 \mathrm{~cm}$. de grosor, de madera no muy pesada para su desplazamiento y se sujetarán a los muros con clavos metálicos. 


\subsubsection{SECUENCIACIÓN Y RECORRIDO PROPUESTOS AL VISITANTE. SUPERFICIES NECESARIAS; DISPOSITIVOS DE EXPOSICIÓN. NECESIDADES}

Hacemos interpretación porque queremos compartir con orros la comprensión de determinados aspectos de mestro patrimonio. para dar a conocer in siu cómo se interrelacionan y por qué son importantes

(VANDER STOEP y GRAMLANN')

Un camino a primera vista incomprensible e inabarcable, un recorrido recóndito -por qué no tortuoso y casi laberintico- lleva a un circulo libre, al aire, en la luz. A un círculo, a una figura perfecta, sin principio ni fin, donde no hay jerarquías ni importancias, donde todo está relacionado con todo.

Con esta metáfora, de un lado, elemental, de otro, muy significativa y elocuente para el visitante, el recorrido por el centro de interpretación del IAPH se muestra persuasivo.

La correlación entre la comparación y el hecho real puede ser realmente convincente si pensamos en el Instituto Andaluz del Patrimonio Histórico como en una institución compleja, pero con finalidades bien definidas. En ocasiones, dificultosa o confusa, como también lo es su propia sede, caótica para el que no la conoce, llena de caminos y múltiples trayectos, desbordante por sus abundantes restos de variadas cronologías y usos.

Hay que conocer a esta institución para comprenderla. Asi, pronto, el 1APH se nos mostrará como una institución en absoluto laberíntica, sino global e integral, en la que el todo es más que la mera suma de las partes. El todo está interrelacionado: sus departamentos, su actividad investigadora... Como el patrimonio, unitaria y al mismo tiempo múltiple, como las disciplinas que en él convergen, también vinculadas y dependientes, el IAPH es en sí mismo y forma parte de un gran círculo patrimonial en el que es difícil encontrar primacias e importancias. En el IAPH, como en un circulo, todo se equipara, todo es trascendente, radicalmente fundamental...

\footnotetext{
${ }^{1}$ MORALES, 1999:283
} 
El centro de interpretación o visitantes del Instituto Andaluz del Patrimonio Histórico tiene su entrada por el acceso principal a la institución tal y como lo concibió el arquitecto rehabilitador del edificio, Guillermo Vázquez Consuegra. De este modo, se recupera una entrada primitiva que le otorga al recorrido, ya desde el principio, cierto valor simbólico, de plena identidad con el proyecto de la institución ${ }^{2}$.

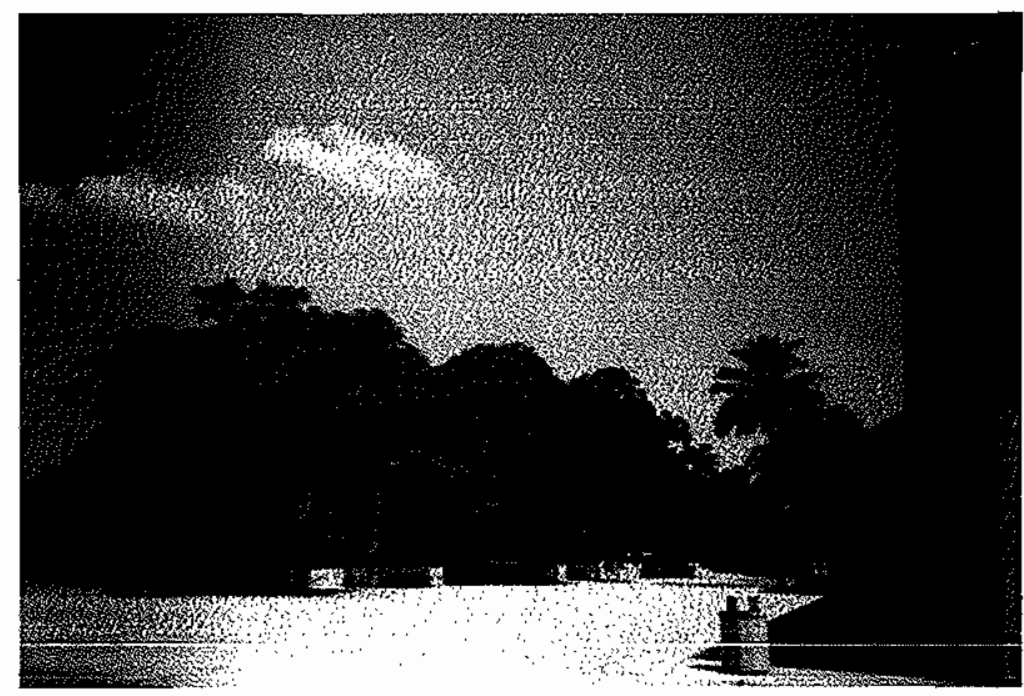

En la entrada, se transmitirá a través de la maqueta existente y murales de grandes fotografias de la institución que llenarán el espacio la primera imagen, de impacto y de incitación al descubrimiento y al conocimiento, del Instituto Andaluz del Patrimonio Histórico.

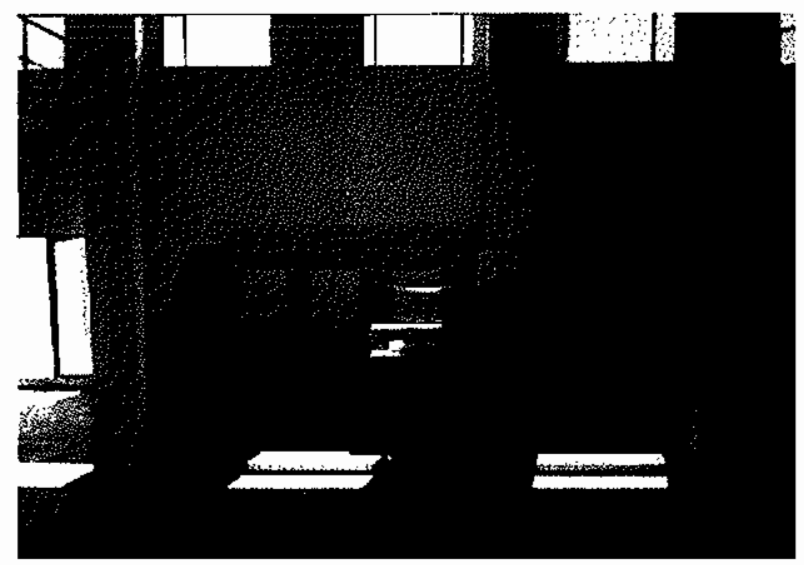

\footnotetext{
${ }^{2}$ Se reserva asi la puerta habitual -en la actualidad- de entrada al hall para personal, usuarios de biblioteca/servicio de información y visitas a personal de la institución.
} 
A su izquierda, el visitante divisa entonces un gran cartel. Es el objeto $n^{\circ} 0$, situado justo encima de la puerta que da acceso a la actual zona de exposiciones.

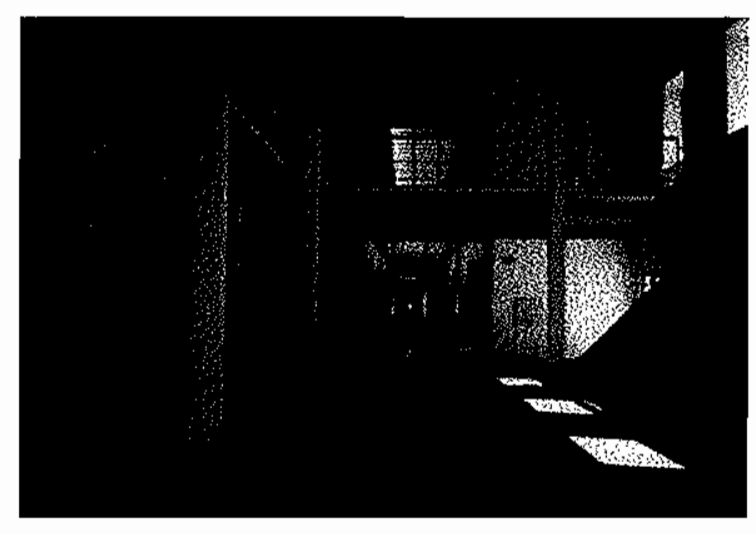

En él se indica, con letras de fuente NewsGothic (justamente, el tipo de letra que corresponde a la institución, según su orden institucional), que ahí está el Centro de Visitantes. Se trata, en resumidas cuentas, de un cartel orientativo y de presentación, en material de cristal y con impresión de letras en color rojo oscuro (Pantone $202 \mathrm{C}$ ):

\section{Centro de visitantes}

Cartel n 0: Cartel anunciador del Centro de Visitantes. Puerta de entrada del Centro

Ya en el espacio de exposición, cruzada la puerta de cristal, el visitante observa, de frente, un panel de bienvenida, al final de la tarima que rodea el resto del horno del siglo XI. Este cartel (panel contrachapado, acabado y barnizado a dos caras con letras impresas en negro -al igual que todos los de la parte introductoria ${ }^{3}$ ) estará a la misma altura y distancia que el actual denominado "Difusión del Patrimonio" y que se halla en el acceso a la zona de exposición:

\footnotetext{
${ }^{3}$ Todos los paneles del Centro de Interpretación, por supuesto, habrán de ser firmes, estables y fácilmente movibles
} 


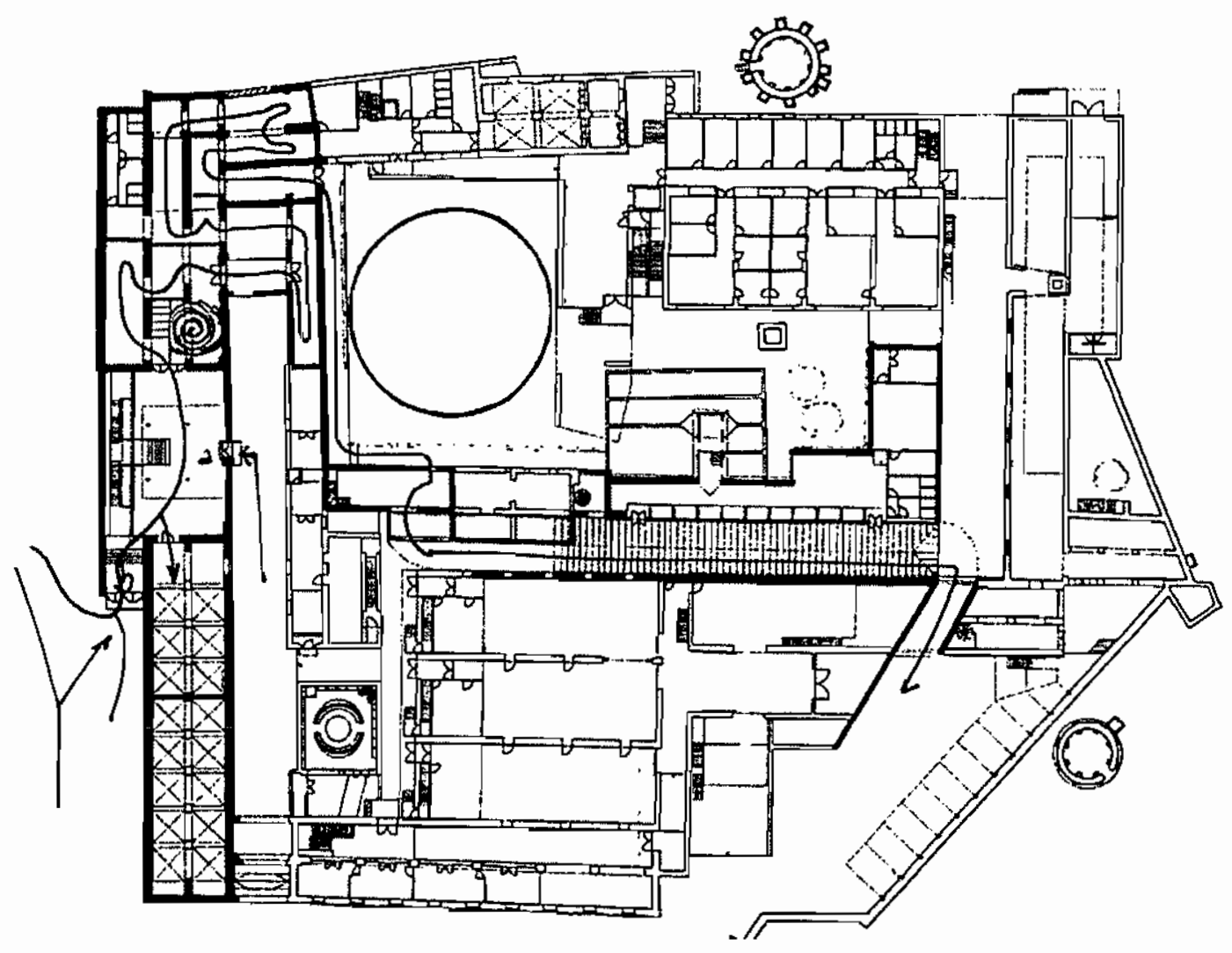

Plano de ubicación del recorrido 


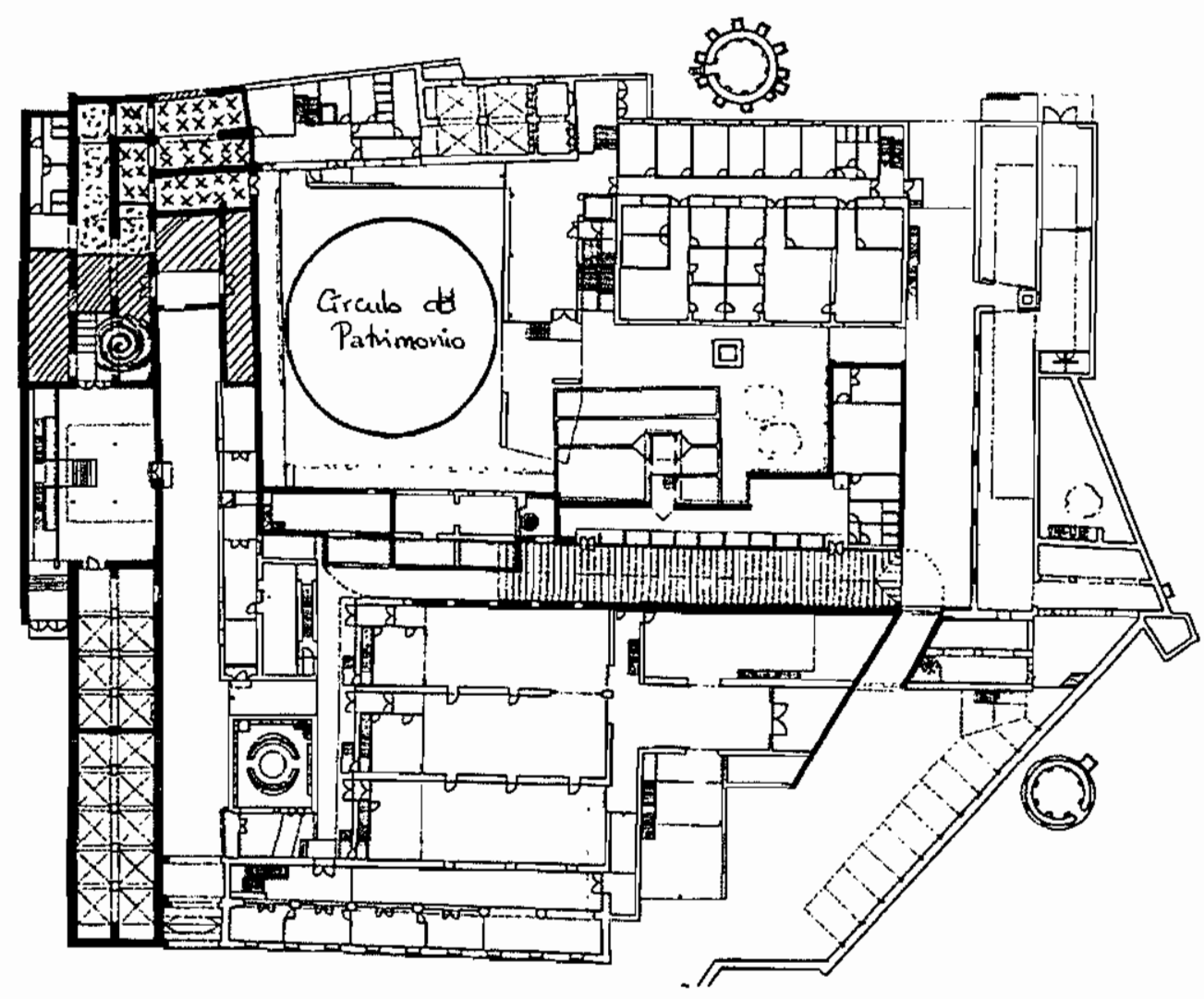

Plano de ubicación de las áreas temáticas del recorrido 


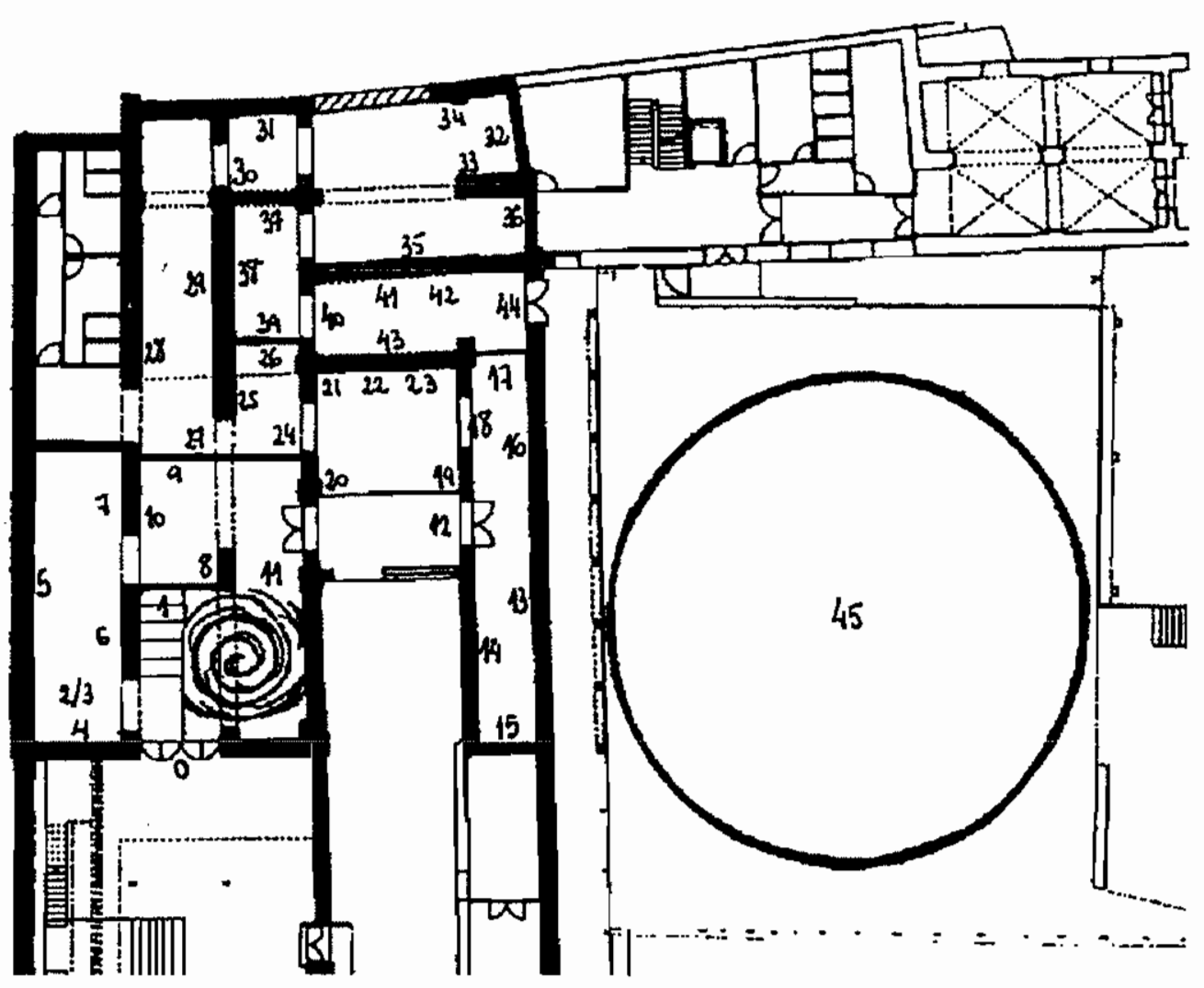

Plano de ubicación de los módulos interpretativos 
Entonces, el visitante, tras la lectura de esta bienvenida, comienza su recorrido hacia la izquierda, entrando en el primer pasillo ${ }^{5}$ del Centro, dedicado especialmente a cuestiones generales acerca del patrimonio y las instituciones que llevan a cabo su gestión.

Un cartel de presentación del IAPH y un cartel de presentación del Centro de Visitantes son los primeros paneles explicativos. Se situarán en el centro del pasillo, de modo que el visitante tenga que esquivarlos para seguir adelante.

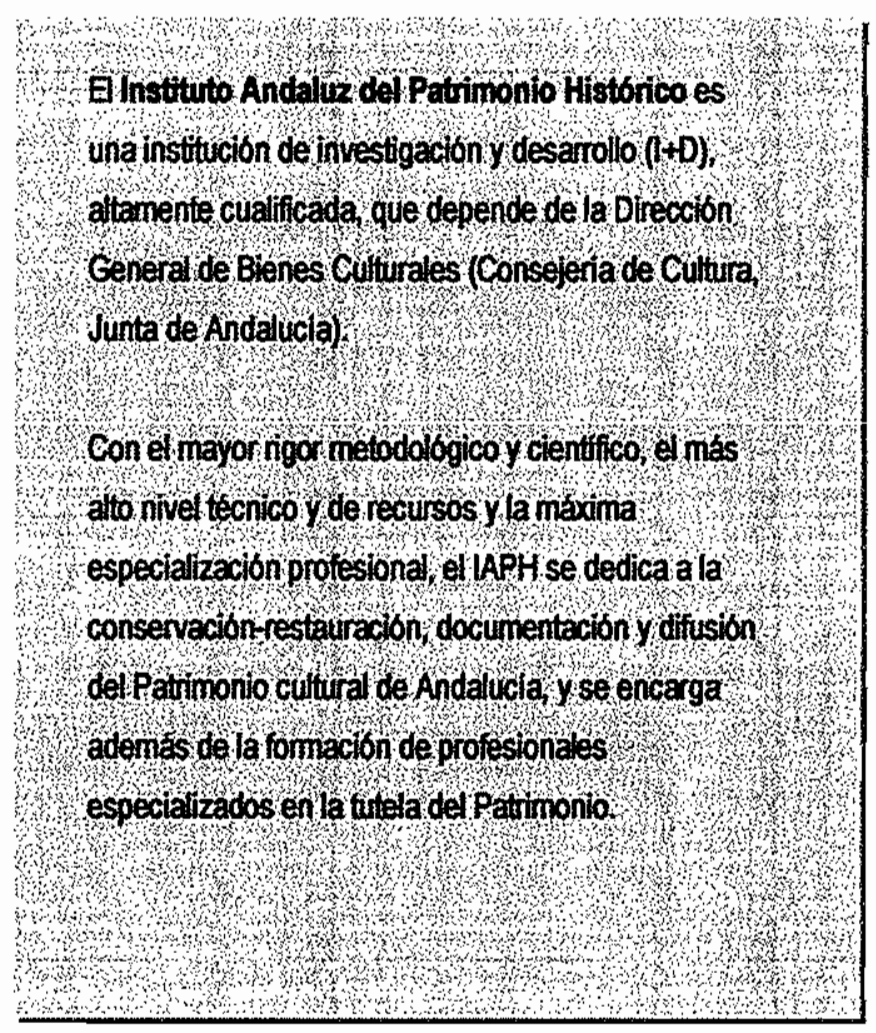

Panel 2: Presentación de la institución

Al lado se presenta el centro de visitantes y su piedra angular: el Círculo del Patrimonio.

\footnotetext{
${ }^{5}$ En esta zona existirá una zona de servicios, de WC, para señoras, caballeros y personas con incapacitación fisica.
} 


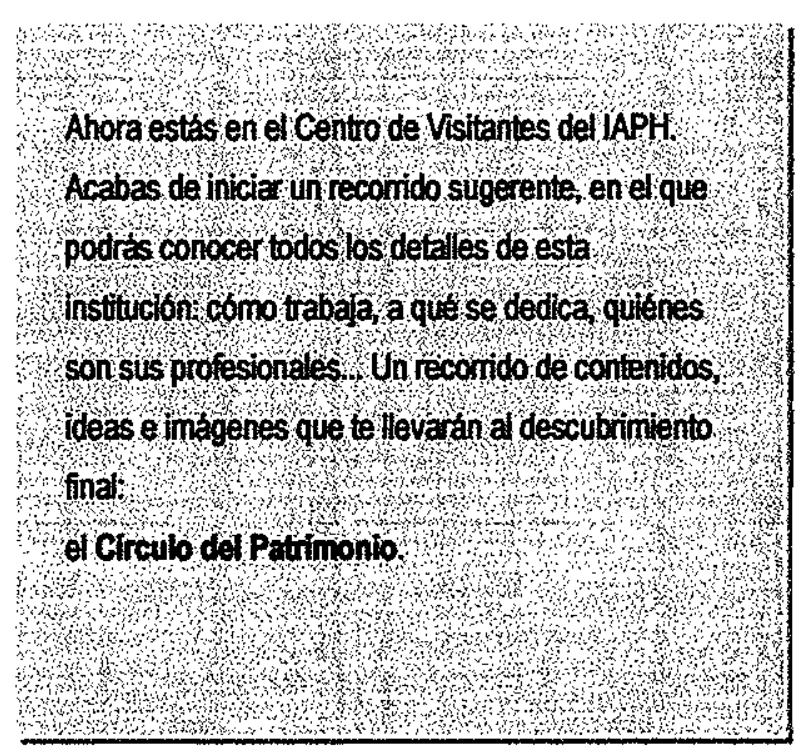

Panel 3: Presentación del Círculo

Por supuesto, el tipo de letra de los textos es la que corresponde al IAPH, la NewsGothic ${ }^{6}$. En ambos casos, se colocarán los paneles en soportes de altura $1,5 \mathrm{~m}$, de modo que resulte un efecto de atril. Los textos quedarán a la altura de la vista del visitante, a $1,40 \mathrm{~m}^{7}$ Estos dos paneles complementarios podrán tener este diseño:

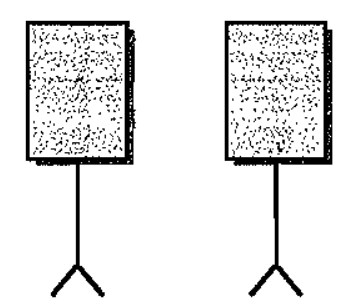

Paneles 2 y 3: diseño

En la pared que se deja atrás se coloca el objeto $n^{\circ} 4$, una mesa-punto de orientación, en la que se ofrecen folletos informativos del IAPH y folletos explicativos -muy breves y simples- del recorrido que el visitante se dispone a realizar. Además, en este folleto se explicarán algunas claves de la visita, por ejemplo el significado de palabras

\footnotetext{
${ }^{6}$ En estos paneles, como en todos, se aplicará el alineado de texto a la izquierda

${ }^{7} \mathrm{La}$ altura se ha determinado en $1,40 \mathrm{~m}$. teniendo en cuenta que la altura de la vista es de unos $10-12 \mathrm{~cm}$. menos que la estatura (LÓPEZ BARBOSA, 1993)
} 
punteadas inferiormente (cuyo sentido es la existencia de información complementaria al tema en atril cercano al panel).

Básicamente, con este folleto al principio de la visita, antes de comenzar a realizar el recorrido previsto, se incide en la idea de círculo, al tenerlo ya visualizado, aunque sea en un simple papel. Se tiene igualmente la idea de un camino por recorter, con un principio y fin, y una orientación que produce en el visitante una sensación de seguridad, de confianza en su visita, de saber qué hacer y de saber que se está haciendo bien, correctamente.

Salvados los paneles 2 y 3 , el visitante se encuentra con un bloque expositivo a la izquierda (objetos $n^{\circ} 5$ y 6 ), que intenta transmitir y clarificar dos ideas básicas para la comprensión del IAPH: qué es el patrimonio y qué es un Instituto de Patrimonio. La primera cuestión será abordada por un módulo $\left(\mathrm{n}^{\circ} 5\right)$ que ofrece -ante imágenes vídeo fragmentadas y continuas de grabaciones de objetos y de lugares del Patrimonio Histórico Andaluz- sontdo, individualizado (mediante audífonos), de un texto similar a este:

[ Hasta no hace mucho tiempo, la palabra Patrimonio tenia el significado simple pero habitualmente aceptado de herencia. Una mirada a través de los periódicos de hoy revelaria rápidamente que el concepto se ha ampliado enormemente y se utiliza en muy diferentes contextos. A los significados de memoria colectiva del pasado o productividad cultural acumulada se suman otros de reciente significación. Ya se habla, por ejemplo de la industria del patrimonio, para hacer referencia a la actividad económica basada en productos y servicios con el patrimonio como componente).

En este contexto, debemos preguntarnos ¿Está creciendo el término demasiado?

Mientras que nuestra época es ya una prodigiosa máquina de producir patrimonio, la sola pronunciación de la palabra Patrimonio adquiere valor de hechizo, y parece que todo el mundo se preocupa más que antes por el pasado y por la historia.

Pero... ¿qué entendemos, entonces, por Patrimonio? ¿es lo mismo Patrimonio que pasado? ¿y Patrimonio que historia?

Mientras que el pasado son los hechos ocurridos en el tiempo pasado y la historia es la narración, subjetiva, de esos hechos, el patrimonio es el conjunto de manifestaciones históricas y culturales del pasado, de bienes materiales e inmateriales sobre los que, como en un espejo, la pobiación se contempla para reconocerse, donde busca la explicación del territorio donde está enraizada.

El patrimonio es, por tanto, lo que la sociedad contemporánea elige para heredar y transmitir. Asi se manifiesta en la Ley de Patrimonio Histórico Español y asi lo ha entendido el Instituto Andaluz del Patrimonio Histórico, que concibe el patrimonio como mantenimiento y transmisión de la memoria de nuestras generaciones a generaciones futuras. ] 
La segunda cuestión, qué es un instituto de patrimonio, se resolverá a través de un panel (6) de tipo conceptual (en negro y Pantone $202 \mathrm{C}$ sobre blanco) donde se aplicará el concepto de la interpretación como revelación basada en la información (TILDEN, citado por MORALES, 1999:46). Se intentará que el visitante descubra por sí mismo, alcance a comprender cómo es una institución de este tipo. Se alentará a reflexionar, siguiendo la recomendación de estimular el pensamiento crítico, brindando los elementos de juicio para que el visilante descubra significados y asuma su virtual importancia, o para que perciba los problemas e identifique sus posibles causas y, a la luz de todo ello, saque sus propias conclusiones (MORALES, 1999:58). El panel puede ser asi: 


\section{¿Qué es un Instituto de Patrimonio?}

Podriamos decir que un Instituto de Patimonio es una institución que, contando con recursos materiales y humanos, trabaja para el Patrimonio, pero esto seria muy simple y poco preciso.

Para conseguir una definición más exacta y correcta, para que comprender realmente qué es el IAPH, to proponemos hacer una suma de todos sus rasgos fundamentales.

Asi, un inslituto de Patrimonio es una institución:

- Integral

porque se plantea el Patrimonio desde una perspectiva múltiple y global, en la que tienen cabida diversas y complementarias actuaciones: INVESTIGACIÓN, DOCURENTACIÓN, CONSERVACIÓN, FORMACIÓN Y DIFUSHÓN.

- De conocimiento porque considera que hay que estudiar previamente y en profundidad el Patrimonio si queremos documentarlo, difundito o intervenir sobre èl.

- De investigación y desarrollo porque realiza actividades cientificas y de desarnollo tecnológico e investiga teorlas, métodos y técricas aplicadas a la tulela de! Patrimonio.

- Modtica porque se trata de un organismo especializado, de alta cualificación cientffico-técnica, que fue creado para ser de modelo en la gestión det Patrimonio y para tener un papel singular en el territorio en el que està inmerso.

- De servicios

porque da asistencia técnica, apoya, asesora y sive a otras instituciones y a la sociedad en general.

- De transferencla

porque todo valor producido por la institución es traspasado de algún modo a la sociedad, que le manca, a su vez, el ritmo y magnitud de lo transmitido.

Panel 6: Instituto de Patrimonio 
En la pared derecha del primer pasillo", el visitante puede ver el mural "Otras instituciones similares" (panel 7): se encuentra con un collage de imágenes, debajo de las cuales se explican brevemente los rasgos significativos de la institución en cuestión. Es fundamental que el visitante pueda descubrir, a través de este panel, qué similitudes y diferencias existen entre el Instituto Andaluz del Patrimonio Histórico y otras instituciones de su misma naturaleza, y si todos responden de un modo u otro a los rasgos definitorios de Instituto de Patrimonio que se han explicado anteriormente

Como corresponde a la parte de introducción, el panel es blanco con letras negras y Pantone $202 \mathrm{C}$.

\footnotetext{
${ }^{8}$ tambièn hay un asiento, desde el que se puede ver el vídeo
} 


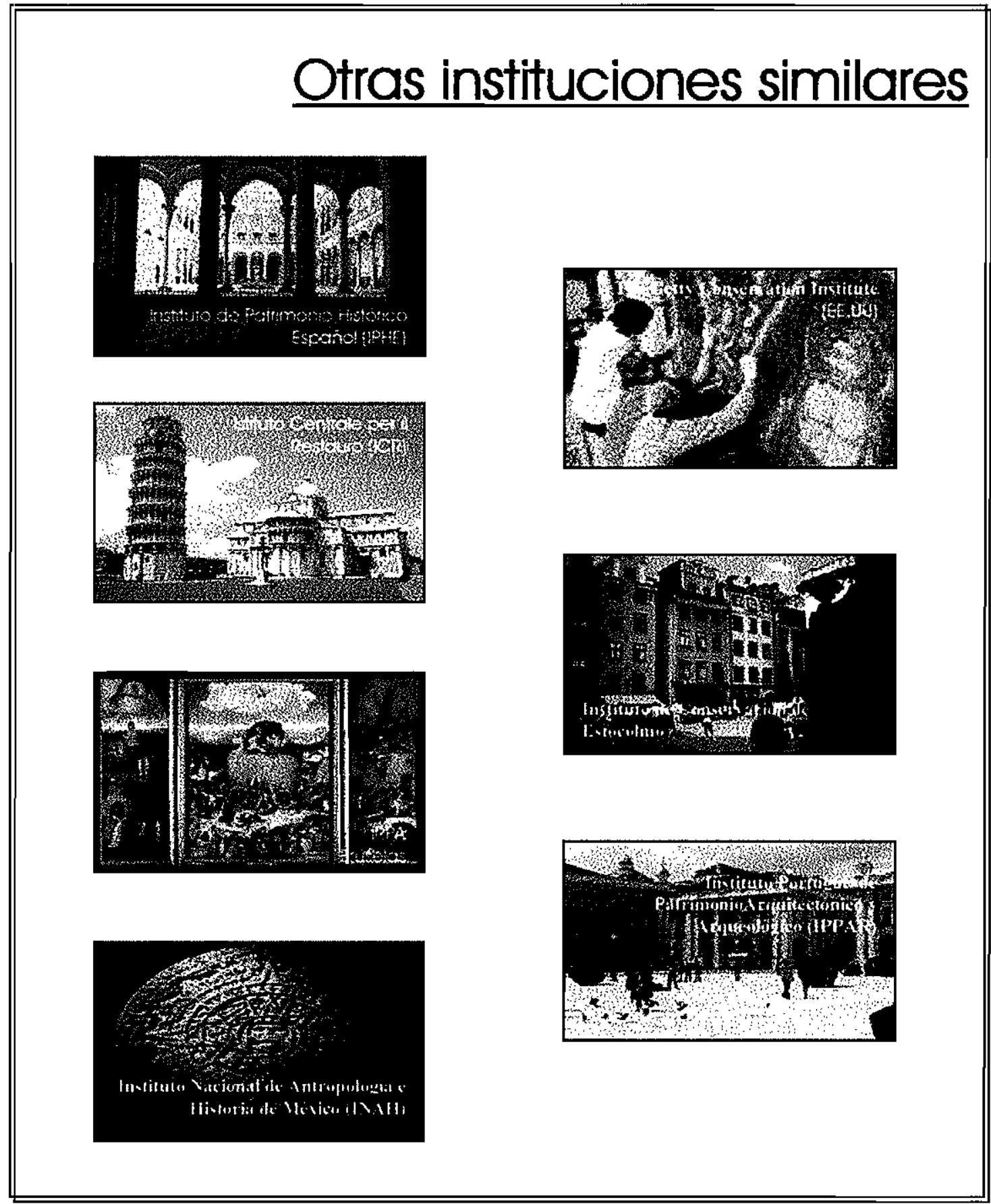

Panel $n^{\circ} 7$ : Instituciones similares 
Se continúa el recorrido por el arco que permanece abierto. El visitante llega a una pequeña zona. todavía correspondiente al primer bloque temático sobre aspectos introductorios, que se dedica -ahora ya más en profundidad- a las claves que definen el IAPH. Los colores cálidos (rojos) continúan, ahora invertidos, haciendo de fondo con letras en blanco. El visitante está rodeado por tres unidades expositivas:

- $N^{\circ}$ 8: De frente observa, impactante, una gran fotografia con pie, situada en un lugar especial y protagonista y dedicada al personal de la institución. Caracterizada por el elemento humano, tendrá un lenguaje emotivo y ocupará el mayor espacio.

- No 9: a la izquierda, un panel de mayor tamaño al anterior representa al IAPH en la estructura administrativa. Con este panel, el visitante sitúa, muy sencillamente, a la institución en el entramado administrativo cultural, además de conocer la estructura jerárquica del IAPH.

- $\quad N^{\circ}$ 10: Acompañando al anterior panel (los paneles 9 y 10 deben ser correlativos, han de leerse unidos, y presentan fondo unitario en Pantone $263 \mathrm{C}$ ), un nuevo elemento expositivo describe la estructura vertebral de la institución.

Debajo de este panel se colocará un atril en el que se ofrecerá información complementaria, concretamente acerca del decreto de creación del IAPH y de sus funciones y competencias. Se trata de un nivel de información más profundo, que supla necesidades de conocimiento mayores. 


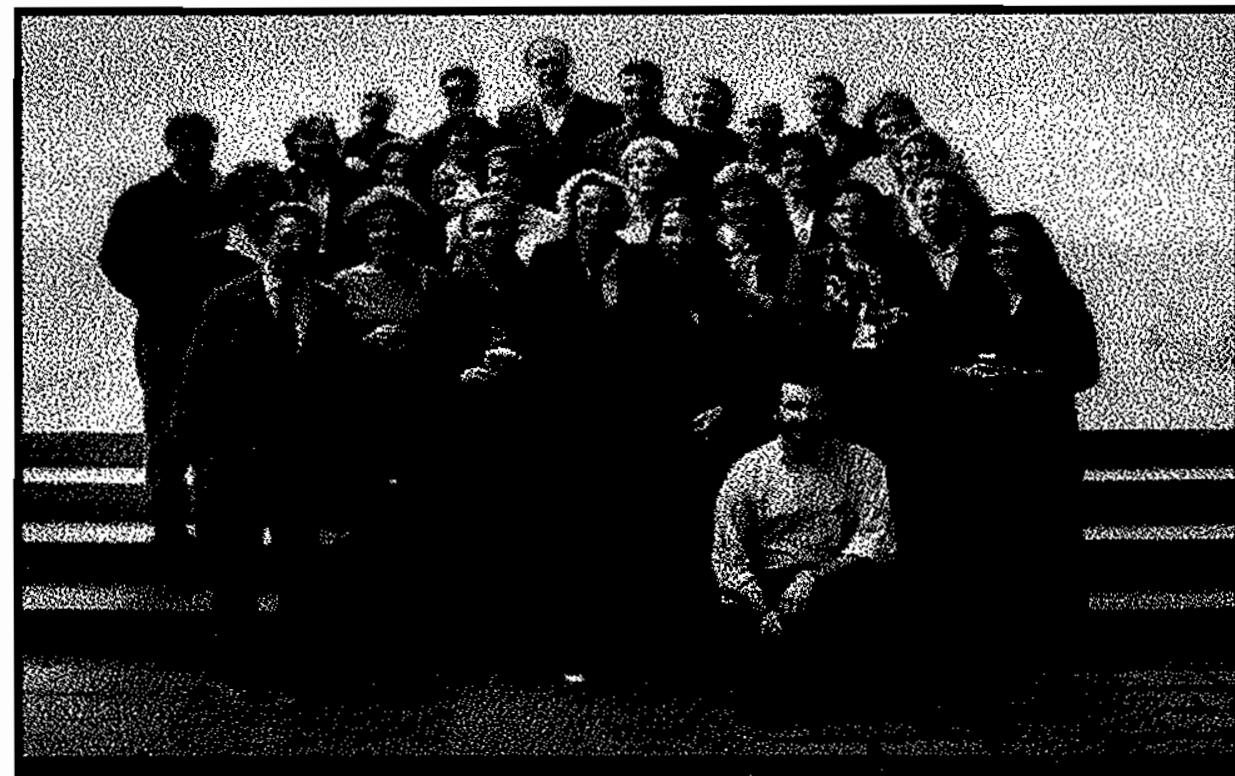

La clave del éxito

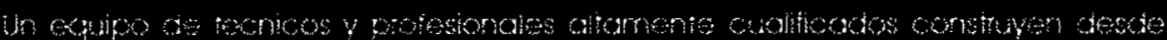

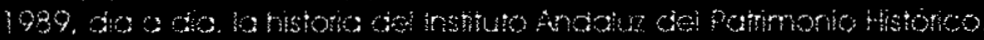

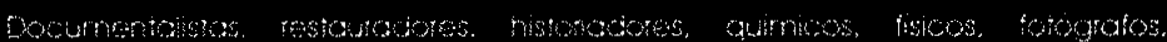

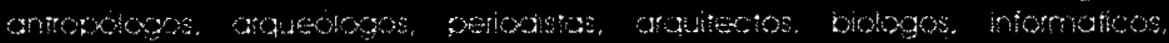
Gogrotos.

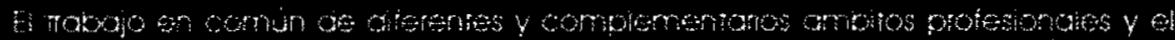

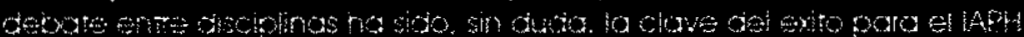

Panel 8: Personal 


\section{El IAPH en su genealogía}
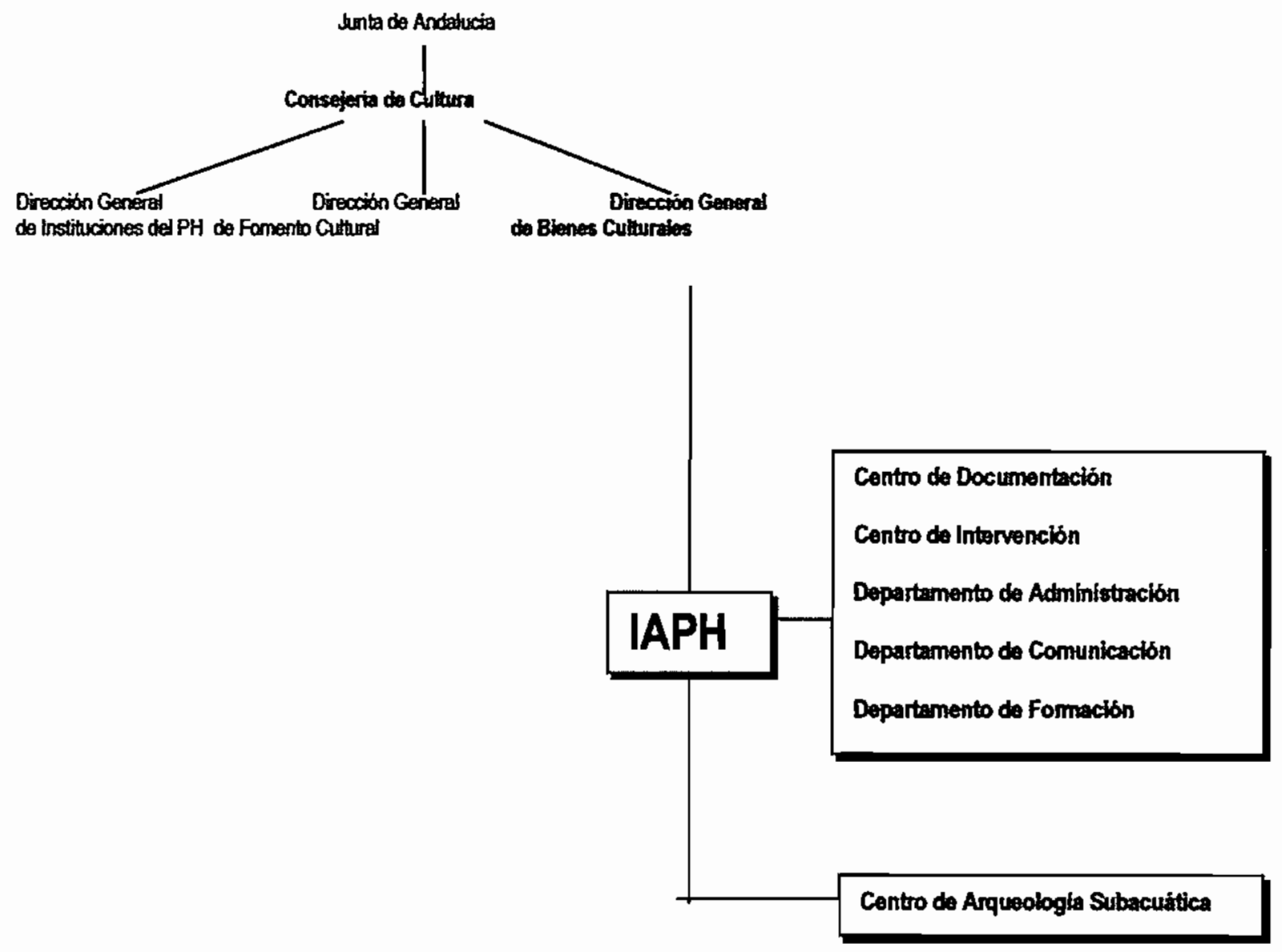

Panel 9: Organigrama 


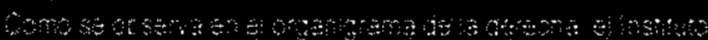

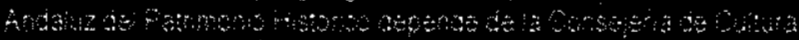

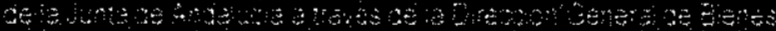

antates

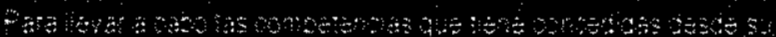

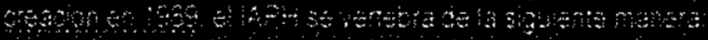

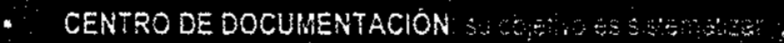

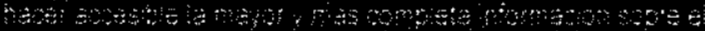

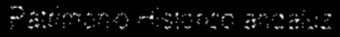

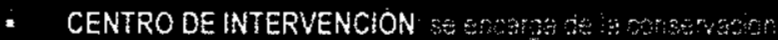

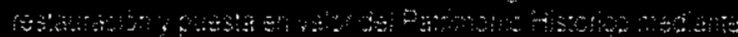
moter

- DEPARTAMENTO DE COMUNICACION SAMTH

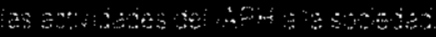

$\therefore$ DEPARTAMENTO DE FORHACION

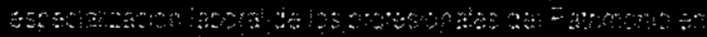
Aratis

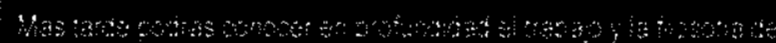

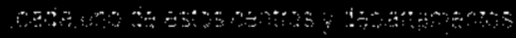

Panel 10: Descripción departamentos

Finaliza de este modo el primer espacio interpretativo (en el plano, zona a rayas negras), que podemos denominar de Introducción y entramos en la zona dedicada a la sede de la institución (rayas rojas) ${ }^{9}$.

El visitante accede, entonces, a un espacio radicalmente diferente, más luminoso y, al mismo tiempo, más misterioso. De la saturación de información del primer grupo de paneles introductorios, pasa a una zona diáfana y despejada, en la que encuentra un

\footnotetext{
${ }^{9}$ En un primer momento se pensó situar el área dedicada a la sede en una de las celdas de legos, al final del recorrido. Sin embargo, era determinante para respetar la coherencia del discurso que el recorrido finalizará con el Circulo del Patrimonio, que éste fuera el último recuerdo que se llevara el visitante
} 
resto de un horno almohade del siglo XI que había visto al principio de la visita $y$, seguramente, había provocado su curiosidad. Ahora es una excelente excusa para satisfacer su posible intriga y preparar al visitante en el conocimiento de la sede del IAPH. Un atril con pequeño panel $\left(n^{\circ} 11\right)$ en letras blancas sobre negro y dorado y sombreado desde el centro -como todos los paneles de este módulo- intenta cubrir estas necesidades:

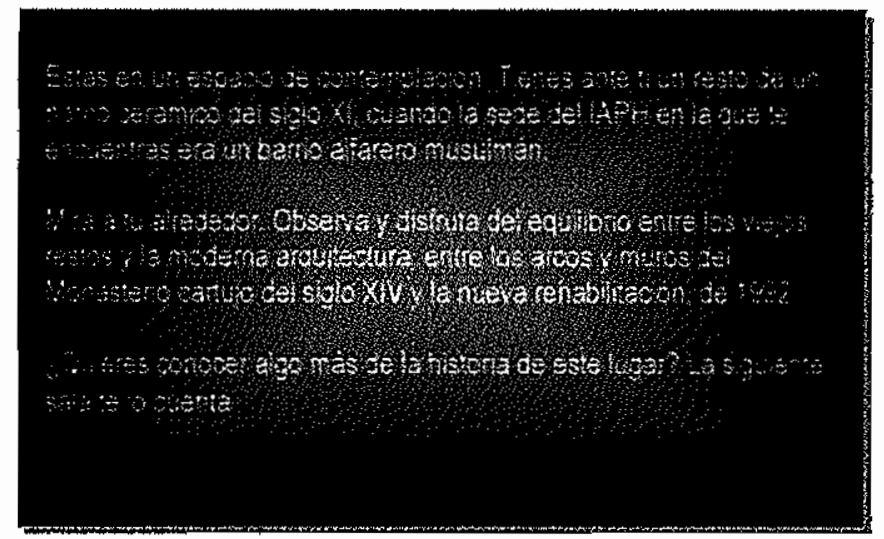

Panel 11: Presentación Sala sede

De esta manera, con un punto de contemplación (habrá otros al final de la visita, en las chimeneas y los restos de celdas de legos) se presenta la próxima sala, dedicada a la sede del IAPH y su pasado histórico. En ella se intentará dejar patente que todo lugar tiene su historia, y que es necesario revivir el pasado para hacer que el presente sea mós placentero y que el futuro adquiera un mayor significado ${ }^{\prime 0}$.

El visitante atraviesa la puerta de cristal que se encuentra a su izquierda y continúa hasta la siguiente puerta de cristal, por un espacio transparente que ofrece la vista del Callejón del Aire. Atravesada la segunda puerta, la sala dedicada a la historia de la sede es una recreación del silencio y la intimidad que ha marcado buena parte de la historia del edificio. Se taparán para ello las entradas de luz de la pared que da al patio (con ello conseguimos dos objetivos: oscurecer la sala e impedir la visión anticipada del Círculo del Patrimonio que se encuentra en el patio). Puntos de luz mury tenues irán guiando al visitante por la sala.

El primer elemento expositivo $\left(n^{\circ} 12\right)$ hace de titular de la sala. A su vez incluye una frase introductoria (de F. Amores) que pretende sintetizar los contenidos de las posteriores unidades de exposición -todos en blanco, negro y Pantone $132 \mathrm{C}$ dorado.

${ }^{10}$ Se trata de uno de los 15 principios de la interpretación de Tílden (MORALES, 1999:51). 


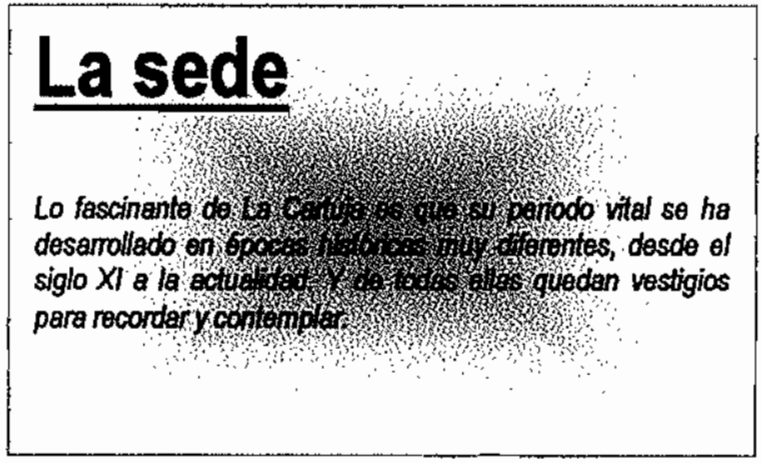

Panel 12: Bienvenida sede

El visitante se encuentra, a la derecha, un área con diversos paneles (paneles 13,14 y 15) que interpretan la historia del edificio sede del LAPH. Todos ellos contarán con información complementaria que se colocará en una pequeña área de descanso situada al lado del panel $n^{\circ} 13$. El área de descanso (objeto $n^{\circ} 16$ ) cuenta con un banco alargado con apartados estancos para guardar hojas de información plastificadas. El modelo puede similar al usado por el arquitecto Juan Pablo Rodríguez Frade en las remodeladas salas del Museo Arqueológico Nacional. 


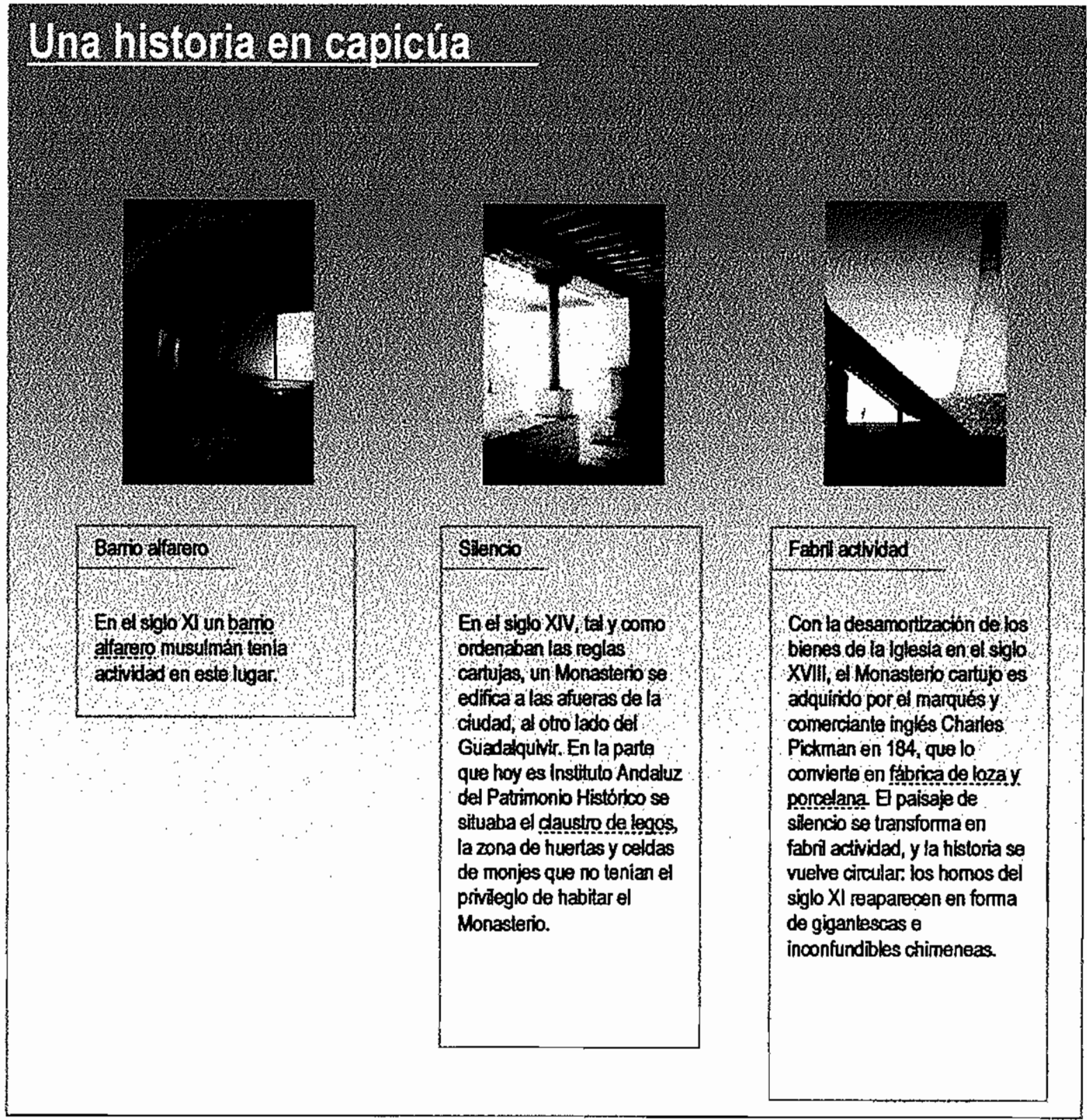

Panel 13: Historia en capicúa 


\section{La rehabilitación de 1992}
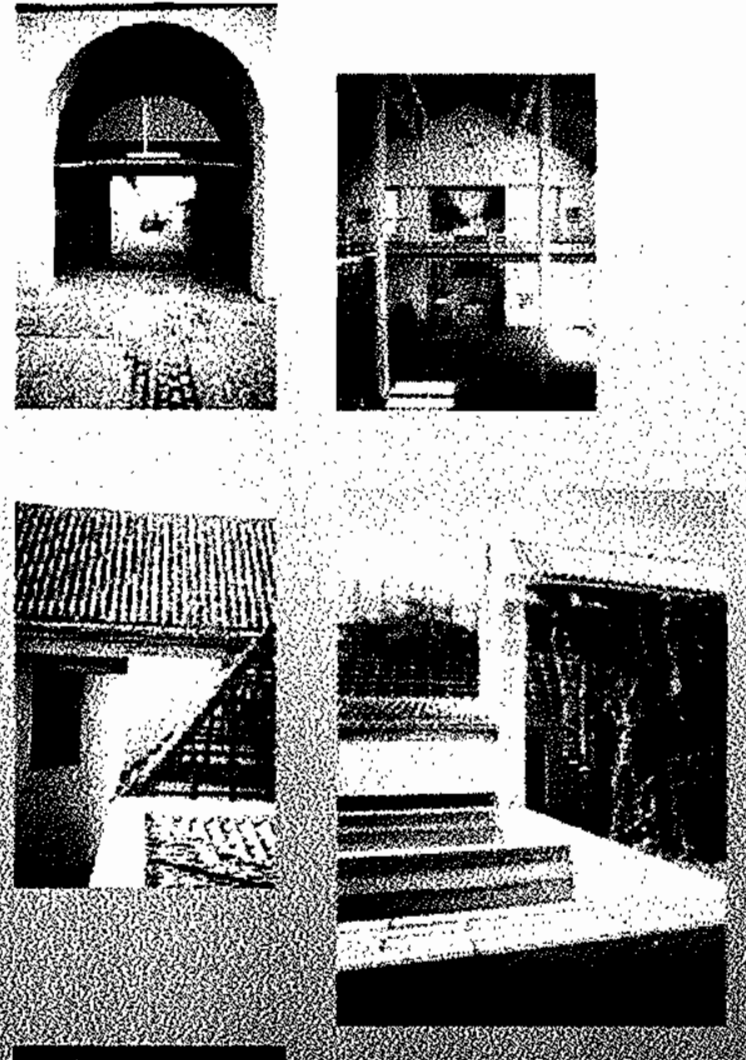

Ubicado en el corazón de la isla de la Cartuja, el Instituto Andałuz del Patrinonio Histórico dispone de una extraordinaria sede surgida del estuerzo realizado por la administración andaluza en el antiguo monasterio de La Cartuja de Sanla Maria de las Cuevas para la Exposición Universal de 1992.

Completamente reslaurado y rehabilitado en sus edificaciones, jardines y huertas, La Cartuja es hoy un espacio de arte y cultura, sede de instituciones tan relovantes como la Universidad Intemacional de Andalucia, es Centro Andaluz de Arte Contemporareo y ef Instituto Andaluz del Palrimonio Histórico.

La actual sede del IAPH responde al proyecto de sehabilitación del arquitecto Gúllermo vázquez Consuegra, caracterizado por tres rasgos fundamentales:

- eddaptacion de las peculiares necesidades del ou Da a ser instituto Andaluz del Patrimono a la dond of o

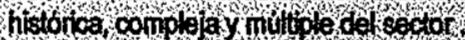

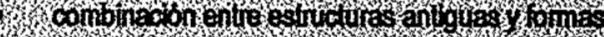

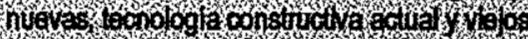

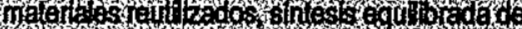
1 o.

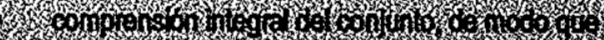

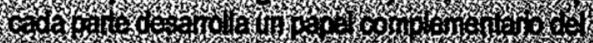

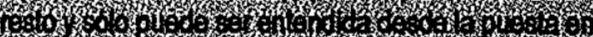
4.
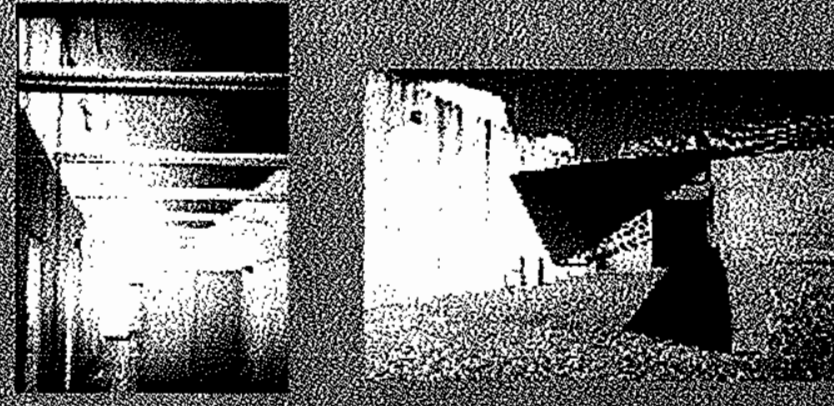

Pancl 14: Rehabilitación 1992 
Este módulo de interpretación incluye un mural $\left(n^{\circ} 15\right)$ que representa un plano de la sede en el que se distinguirán con colores, dibujos y fotografias las diferentes fases históricas del edificio. Se trata de un panel de síntesis que, a través de imágenes, busca despertar el interés del visitante por el conocimiento de la sede. Este módulo de exposición podría ser similar a este ficticio que presentamos:

\section{Superposición de etapas constructivas}

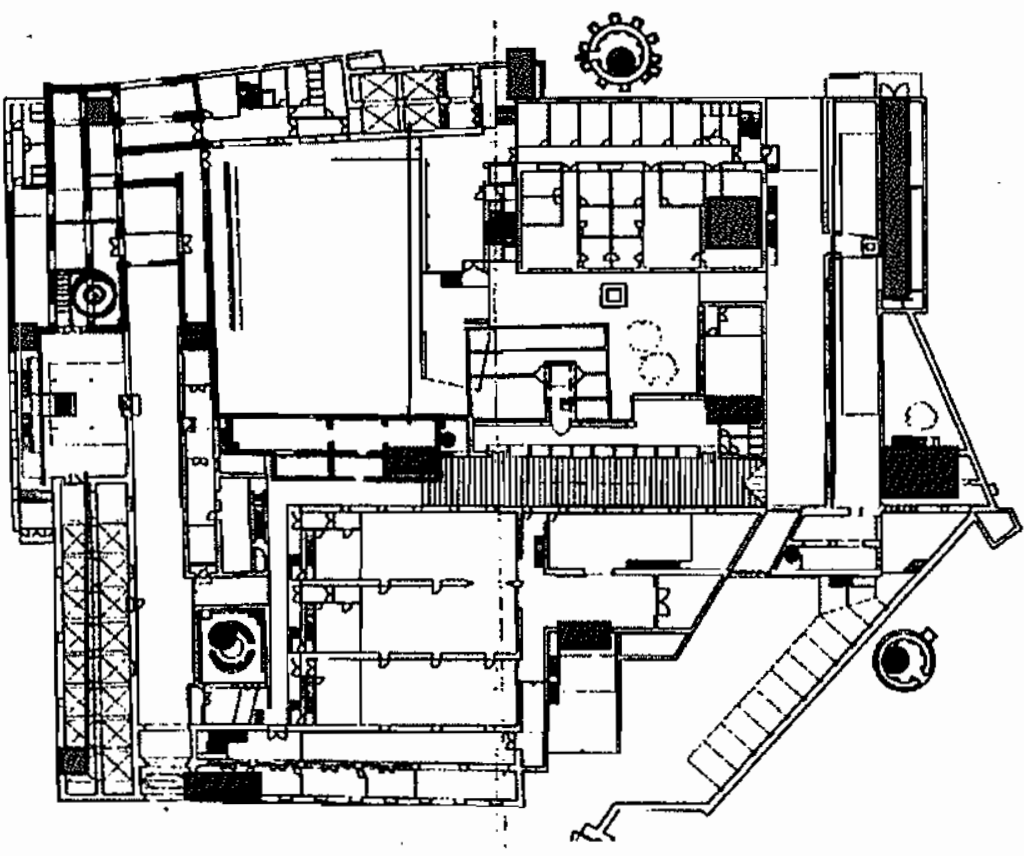

- Restos época almohtado

- Restos del Morasterio

- Restos capación francos

- Restos fábrica Pickoman

* Rehrbititación 1992

Panel 15: Etapas constructivas

Estos tres paneles que el visitante deja atrás se complementan en cierto modo con los próximos elementos expositivos, introductorios de la siguiente sala dedicada al Centro de Arqueología Subacuática. La sede del IAPH en Cádiz tiene en el Centro de Visitantes un lugar reservado y prioritario: la sala más central y con mayor luminosidad y espacio. El panel 17, titulado La sede en Cádiz, inicia, pues, una zona interpretativa de alto valor simbólico y sorpresivo, de provocadoras sensaciones para el visitante. 


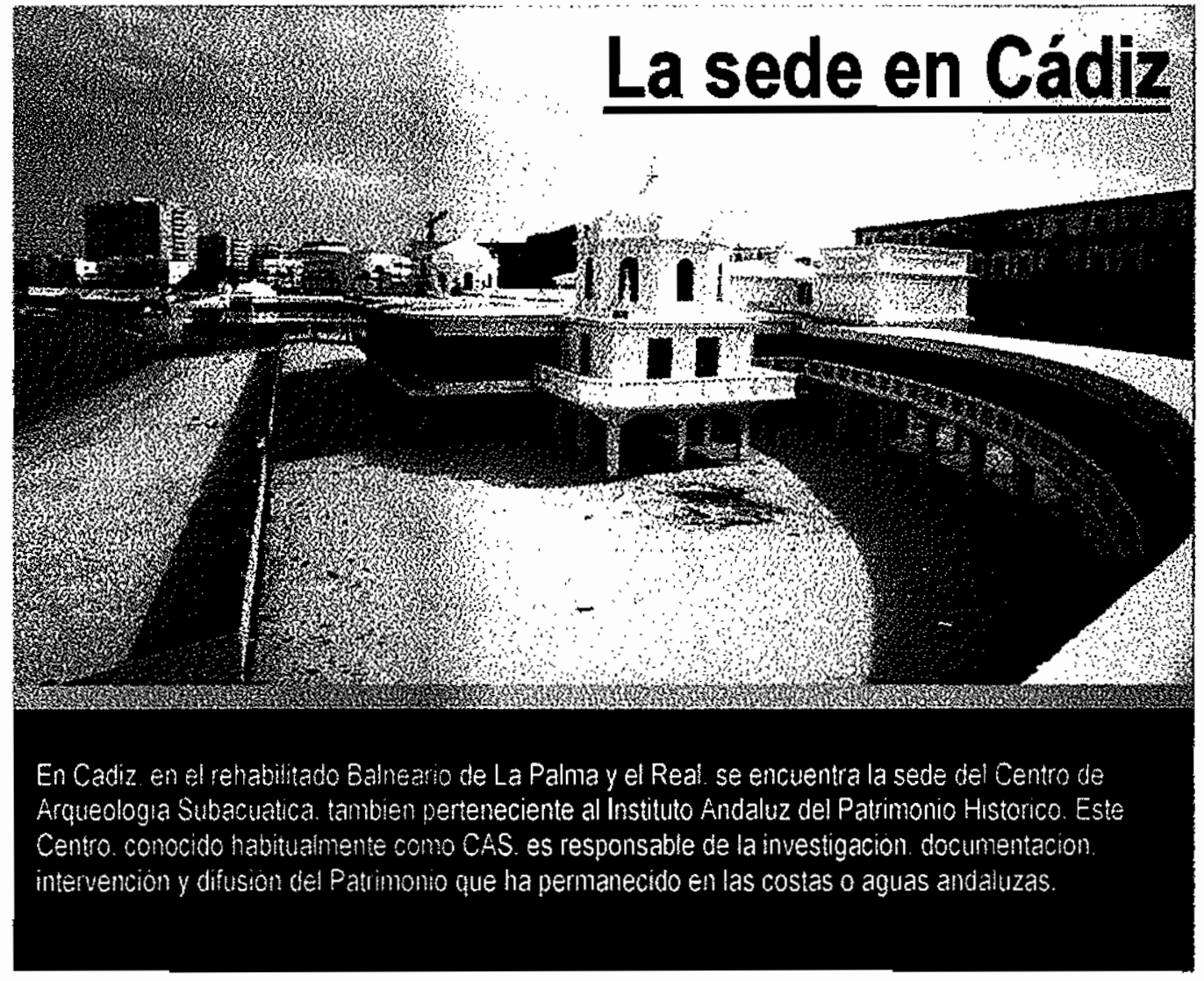

Panel 17: Sode CAS
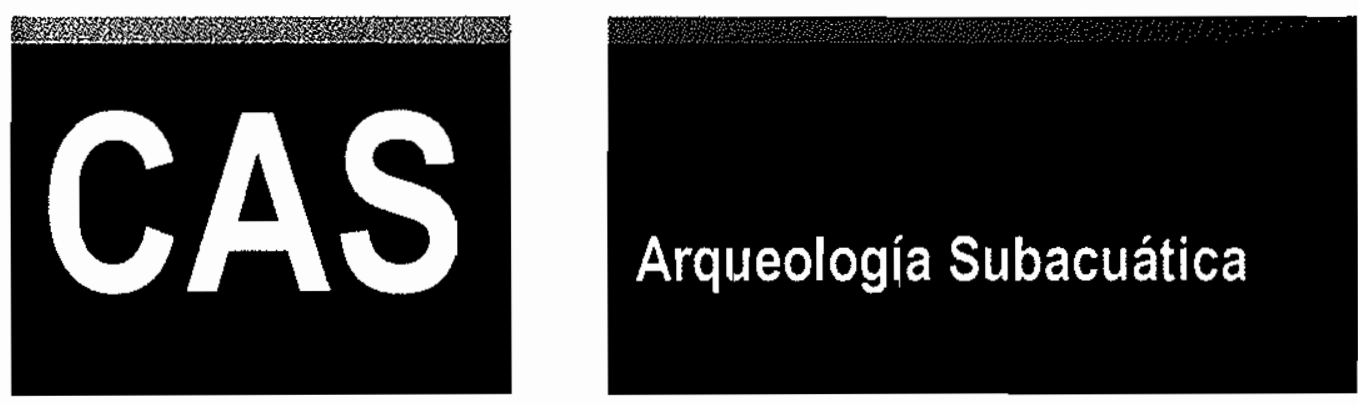

Paneles 18 a. y 18 b. Bienvenida CAS 
Estos dos paneles se situarán a ambos lados de la puerta que da entrada a la sala del Centro de Arqueologia Subacuática. Los colores ponen en relación la sala anterior (sedes, Pantone 132 C) con la posterior (CAS, Pantone 294 C).

Continúa el recorrido hacia la sala destinada al CAS, una sala con connotaciones marinas por su transparecia, amplitud y predominio del Pantone $294 \mathrm{C}$. Esta zona debe hablar de la función y misión del Centro de Arqueología Subacuática, de sus actividades fundamentales, pero sin anticipar contenidos de documentación, intervención, investigación o difusión que están reservados para más adelante. De esta decisión se deriva que los elementos siguientes se refieran a cuestiones muy concretas, como los proyectos del CAS o la propia disciplina de la arqueología subacuática. La sala cuenta con cinco módulos de interpretación, todos muy ilustrativos con el fin de paliar la ausencia de presencia fisica del visitante en la sede real:

- $\quad N^{\circ}$ 19: video sobre las actividades del CAS

- $\quad N^{\circ}$ 20: cuaderno de fotografias de Patrimonio Arqueológico Subacuático andaluz

- No 21: atril con hojas de sala (información complementaria de la filosofia estructura y competencias del CAS)

- $\quad N^{\circ} 22$ : panel explicativo del Centro de Arqueología Subacuática

- $N^{\circ}$ 23: panel explicativo de uno de los proyectos del CAS (mural electrónico) 


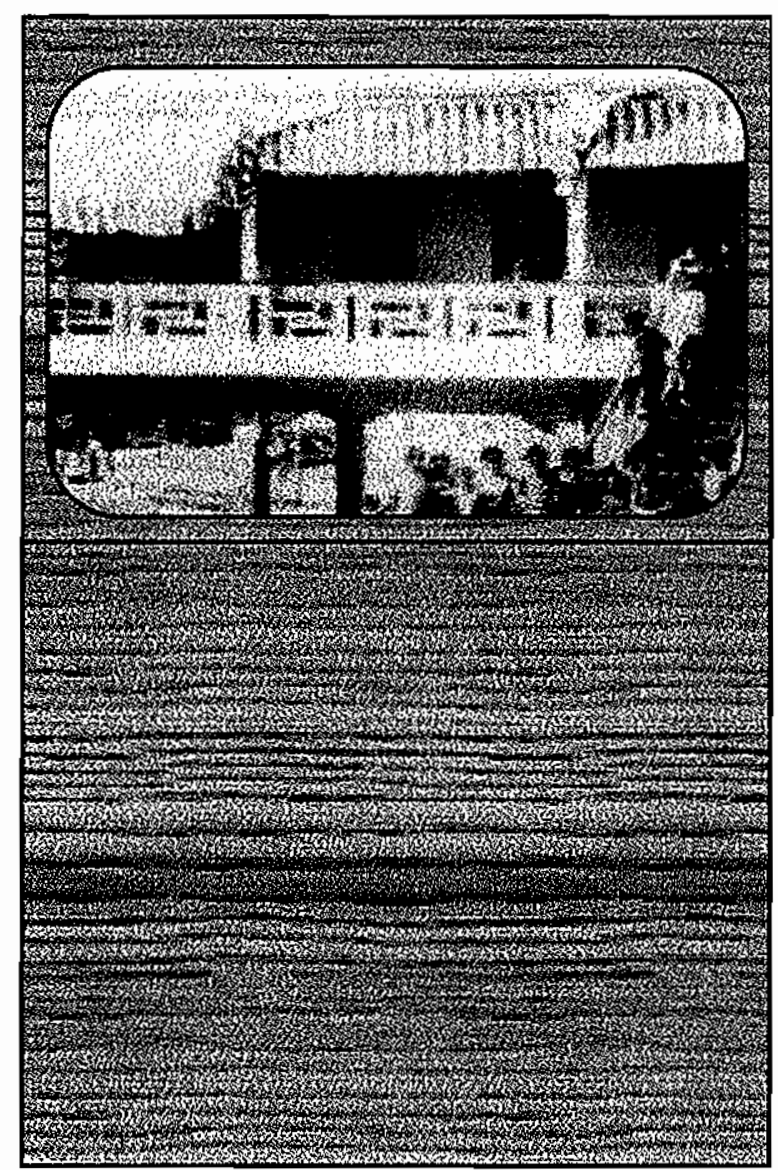

Objeto 19: armario para proyección de video CAS

Este armario, en la esquina inferior derecha según se ve en el plano adjunto, cuenta con una parte superior y otra inferior. En la primera se colocará el monitor, en la segunda -detrás de una disimulada puerta- el aparato de vídeo.

En la esquina inferior izquierda, un atril sostiene una especie de cuaderno de bitácora con fotografias sobre diferentes piezas y aspectos del Patrimonio Arqueológico Subacuático (PAS) andaluz: 


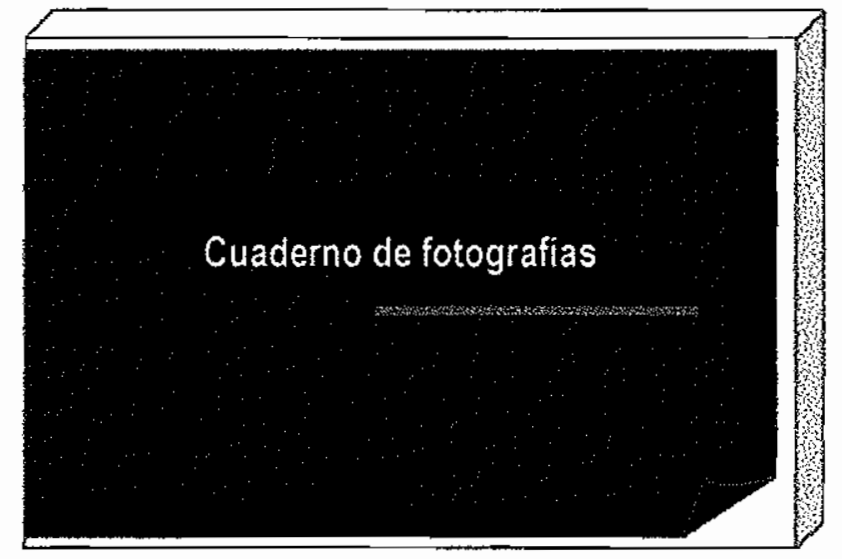

Objeto 20: Cuaderno de fotografias

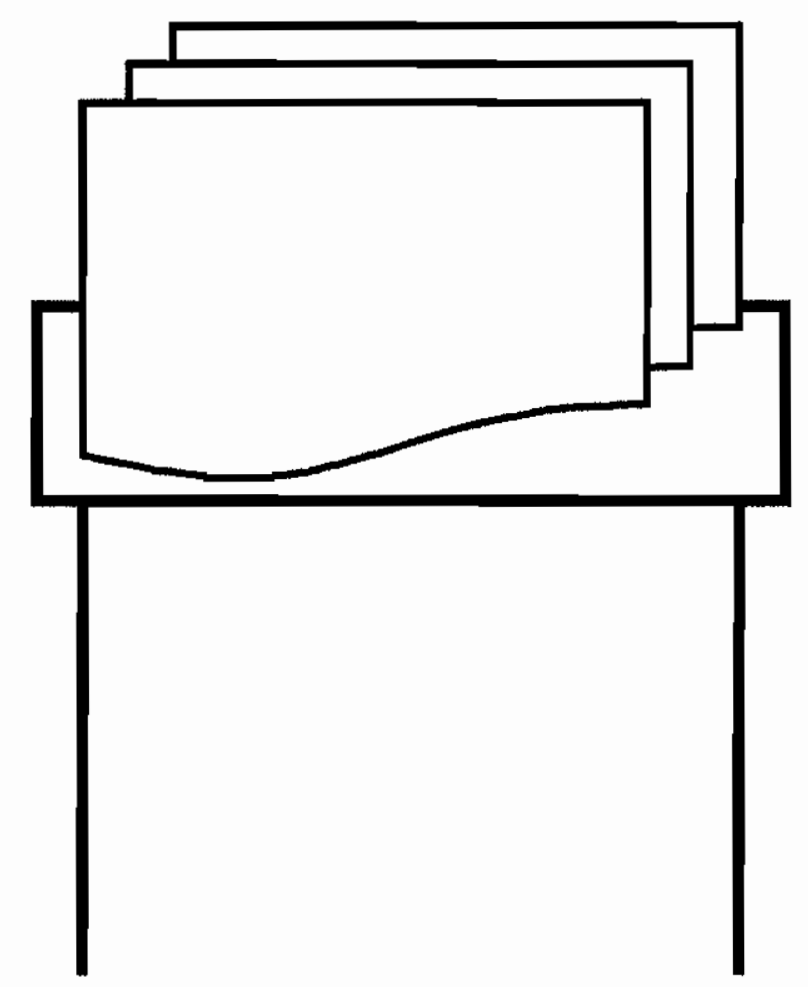

Objeto 2I: Atril con información complementaria 
El atril se colocará en la esquina superior izquierda -según plano en papel. Al lado, en la pared más alargada se podrán observar las dos unidades de exposición más importantes de la sala, los paneles explicativos $n^{\circ} 22$ y 23 , a la izquierda y a la derecha en la pared respectivamente.

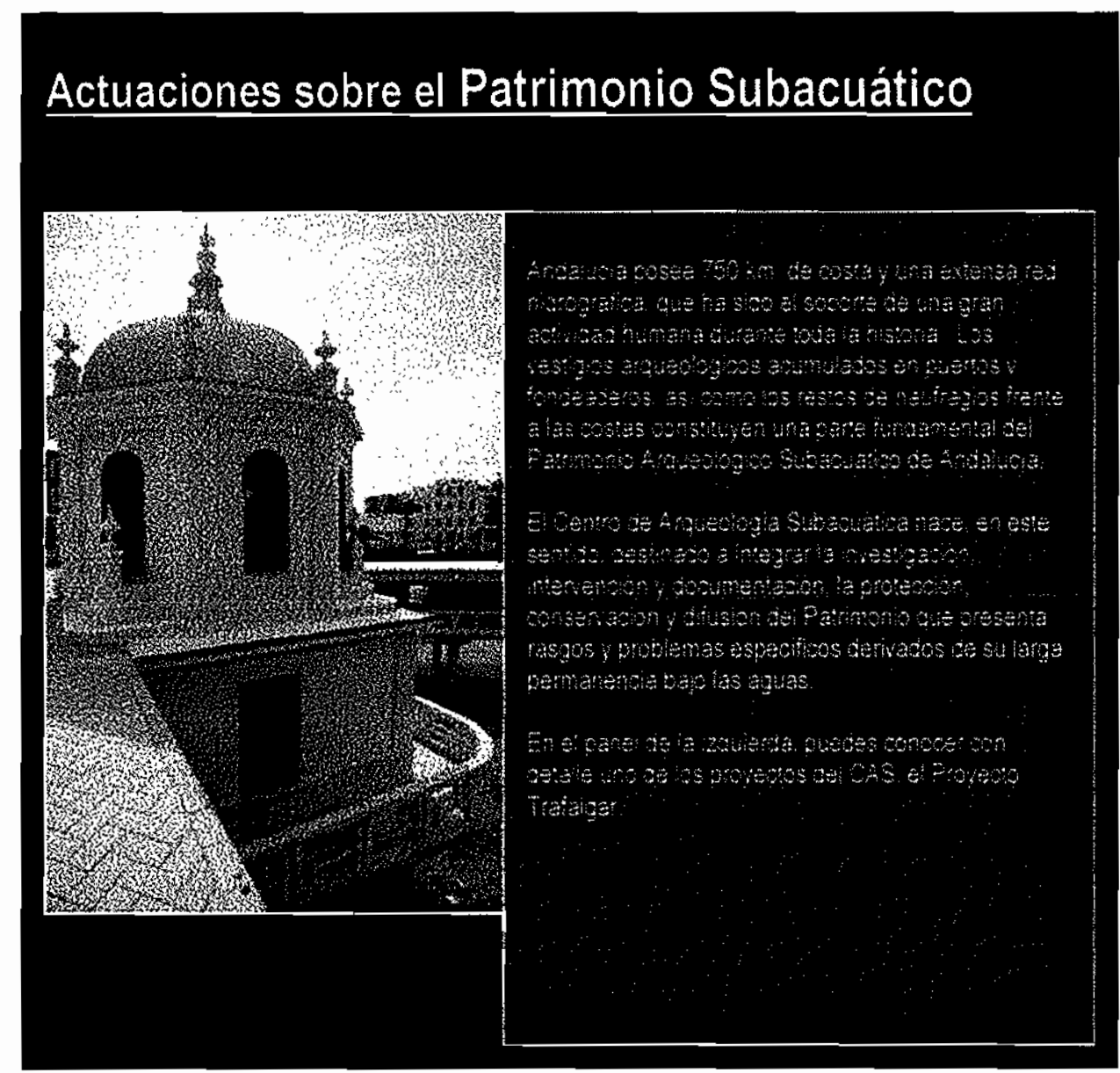

Panel 22: Patrimonio Subacuático

El panel $n^{\circ} 23$-de mayor anchura que el anterior- es un mural electrónico que presenta dos posiciones, dos apariencias, según se apriete el botón negro (que ilumina la historia de la batalla) o el botón azul (que ilumina los restos arqueológicos subacuáticos y la actuación del CAS en cada uno de ellos), botones que están situados en un atril apoyado en la pared debajo del mural. 


\section{Provecto Trafaloar: vestiolos en el aqua}

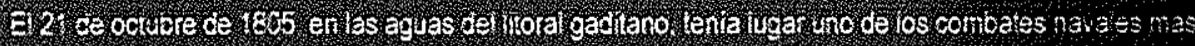

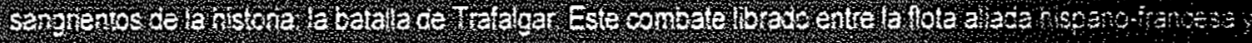

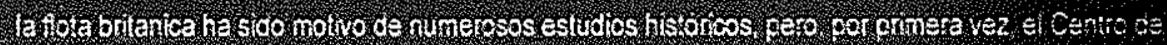

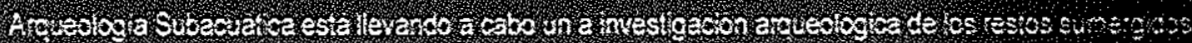

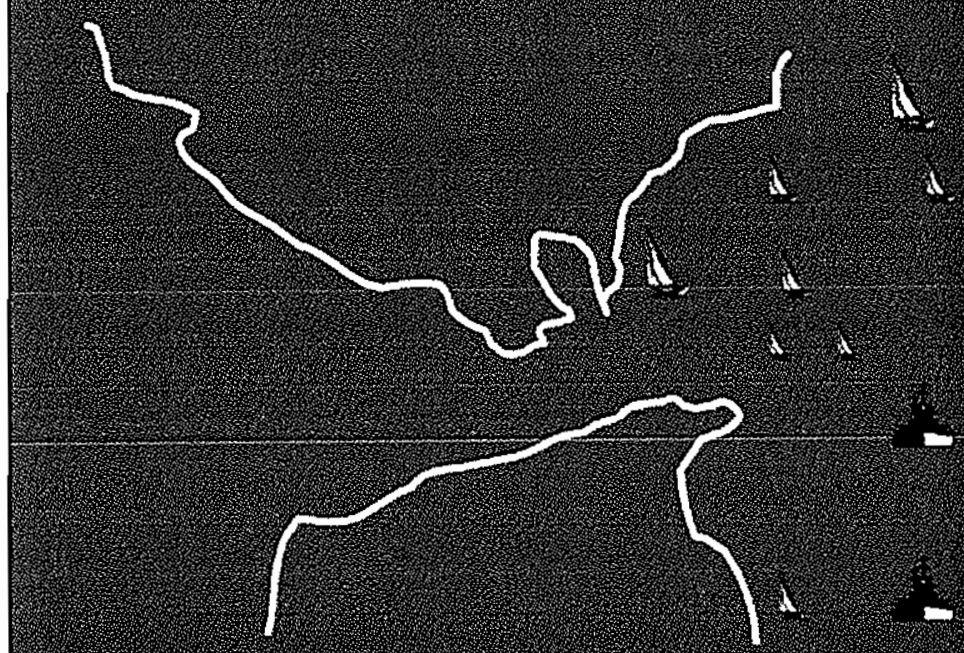

1.

$=$

i.

$-$

\section{Breve crónica de la batalla}

Aqui debe aparecer un texto de caracter historico sobre la batalla. Apui debe aparecer un lento a zarage:

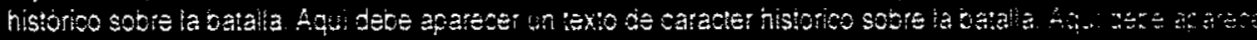
un texto de caracter historico sobre la batalla Aqui debe aparecer un texto de caracter historico s.t. batalla.

Panel 23 (botón negro): Trafalgar 


\section{Provecto Trafalgar: vestigios en el aqua}

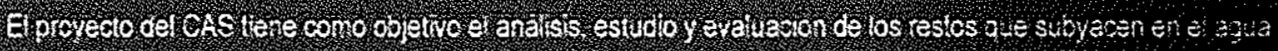

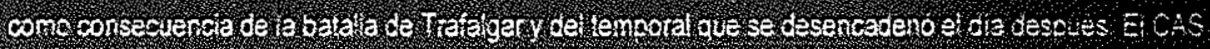

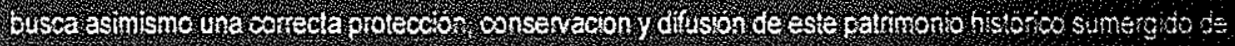
Aroative

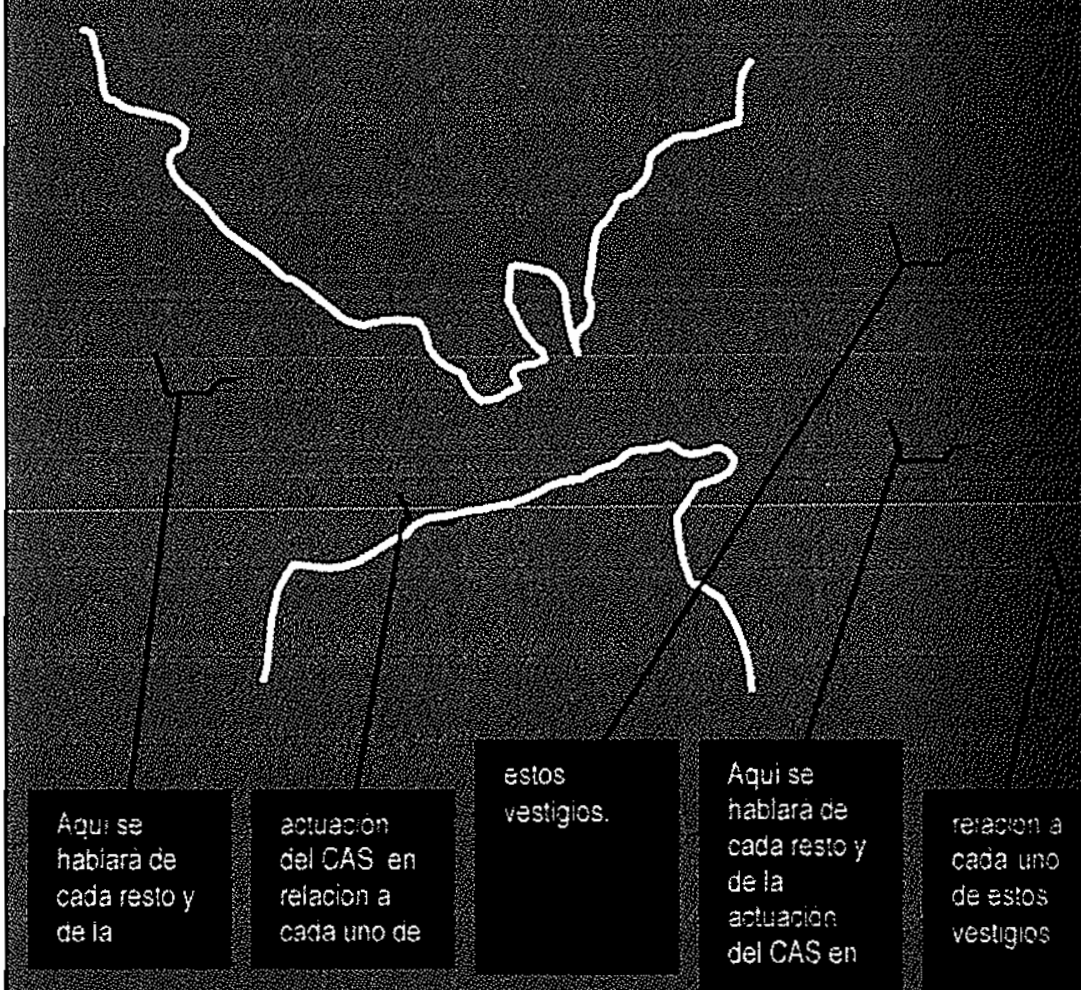

Pancl 23 (botón azul): Trafalgar 
Finaliza la interpretación de las sedes del IAPH y del Centro de Arqueología Subacuática Comienza la interpretación de las disciplinas que abarcan el Patrimonio y que vertebran la estructura de funcionamiento de la institución, el esquema de trabajo del Instituto Andaluz del Patrimonio Histórico: investigación, documentación, intervención y difusión (comunicación/formación).

En primer lugar, saliendo desde la sala del CAS, el visitante llega al espacio dedicado a la investigación (zona punteada en negro, en el plano), principio y fin de la esencia de la institución. Múy sencillamente, se explicará el carácter de investigación y desarrollo del IAPH y cómo toda su actividad confluye en su misión investigadora y de conocimiento. Dos paneles resumen el contenido de esta temática fundamental del Instituto, el $\mathrm{n}^{\circ} 25$ (de frente a la entrada, fotografia donde se puede percibir la actividad investigadora del IAPH) y ${ }^{\circ} 26$ (a la derecha, panel explicativo). Previamente, en la puerta de acceso a esta zona de investigación, un pequeĩo atril $\left(n^{\circ} 24\right)$ situado a la izquierda, reubicará el sentido del centro de interpretación. El disefio de este panel será el que posteriormente sirva de introducción al Centro de Intervención y a Difusión/Formación. El tipo de material será el mismo que el de los primeros paneles del Centro (panel contrachapado, acabado y barnizado a dos caras con letras impresas en negro):

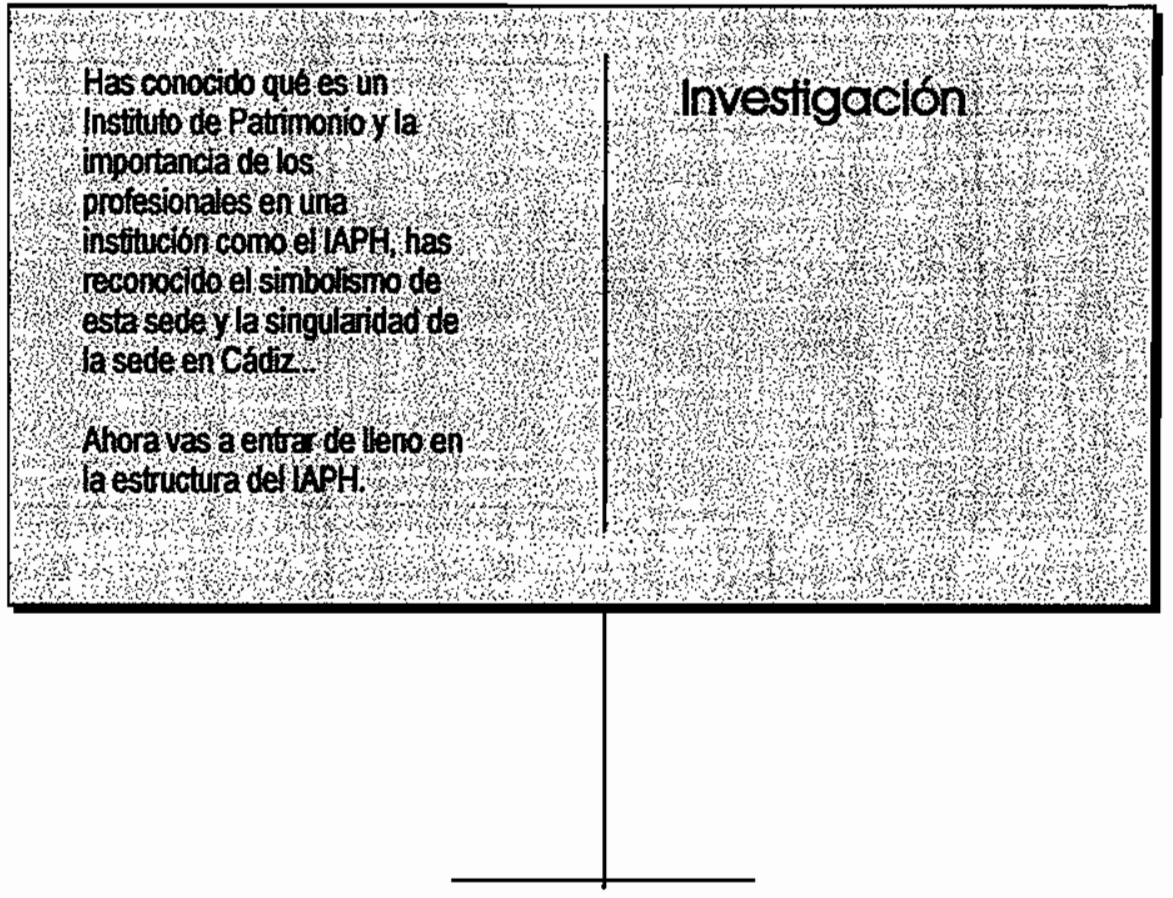

Objeto $n^{\circ} 24$ : atril introducción investigación 


\section{IAPH: la investigación radical}

Desde su creación, una do las lineas basicas de actuacionn del Instituto Andaluz del Patrimonio Historico fue la investigacion aplicada, el estudlo y avance de teorlas, métodos y técricas aplicedas at Patrimonio Histórico.

Como institución I + D (Irvestigacionn + Desarrollo), ed lAPH dedica gran parte de sus esuerzos a las actividades de investigación, inscritas siempre dentro de los programas marco europeos, nacionales y andaluces.

Esta proyección investigadora del centro le leva a formudar importantes proyectos propios y en colaboración con otras instituciones cientificas nacionales y extranjeras, entendiendo siempre que cuanto mejor conozcamos nuestro patrimonio más lo podremos valorar.

Panel 26: investigación

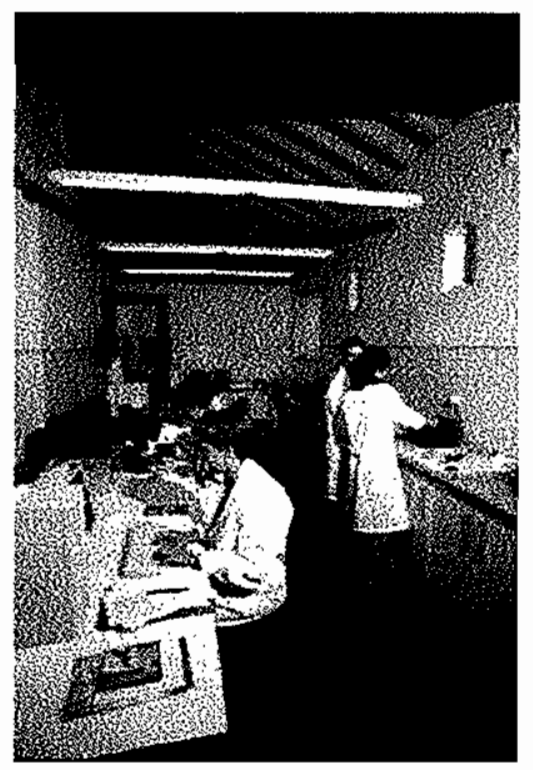

Panel 25: fotografia investigación 
Dejando al paso este módulo -muy condensado (por razones de espacio, pero también de dificultad de transmisión a un visitante no especializado en la materia)- el visitante alcanza la zona de interpretación de uno de los ejes vertebradores de la institución: el Centro de Documentación (área de puntos rojos en plano).

Este módulo, que comienza con un atril anunciador, presenta una característica que lo diferencia del resto de zonas interpretativas: la imagen. Frente a la gestión del conocimiento, a la información como base de un sistema documental, en contra de la abstracción que representa para el visitante un Centro de Documentación, el módulo cuenta con dos claves interpretativas: I) la abundancia de imágenes y 2) el énfasis en la utilización de las nuevas tecnologías, como símbolo de avance y desarrollo y como vía de transmisión de la información más rápida y efectiva. En esta zona interpretativa, como en las anteriores y posteriores, se evitará, en general, toda alusión técnica y el uso de conceptos científicos, a menos que sea imprescindible y expliquemos su significado. La brevedad, simplicidad y claridad han de buscarse constantemente, sabiendo que en interpretación es mejor hacer poco que demasiado (PASKOWSKY, citado por MORALES, 1999:70).

Estos dos puntos fundamentales del módulo interpretativo se ponen de manifiesto en el centro de visitantes, a través de la diferenciación visual entre las dos paredes laterales del pasillo dedicado a la documentación en el IAPH. La pared derecha, según se mira en el plano, acoge un mural de fotografias (objeto $n^{0}$ 29) sobre el Centro de Documentación; la pared izquierda es recorrida por un gran módulo de madera (objeto $n^{\circ} 28$ ) en el que se insertan paneles explicativos y ordenadores de consulta ${ }^{11}$.

Empezamos haciendo un boceto del atril de introducción $\left(n^{\circ} 27\right)$ :

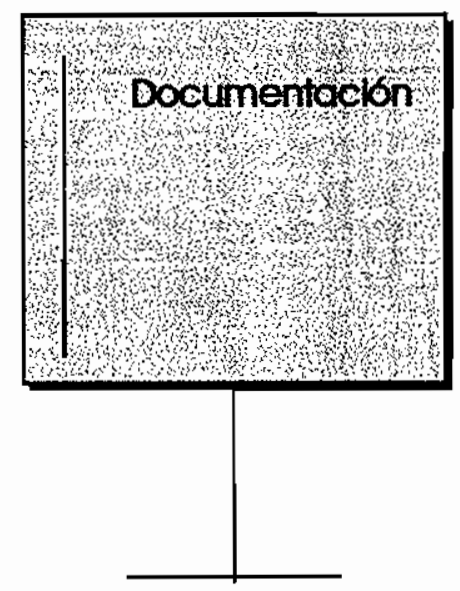

${ }^{11}$ Siguiendo las recomendaciones de Larry Beck y Ted Cable (MORALES, 1999:51), seremos cautos con la utilización de nuevas tecnologias aunque siendo conscientes de que pueden revelar el mundo de maneras muevas y apasionantes. 


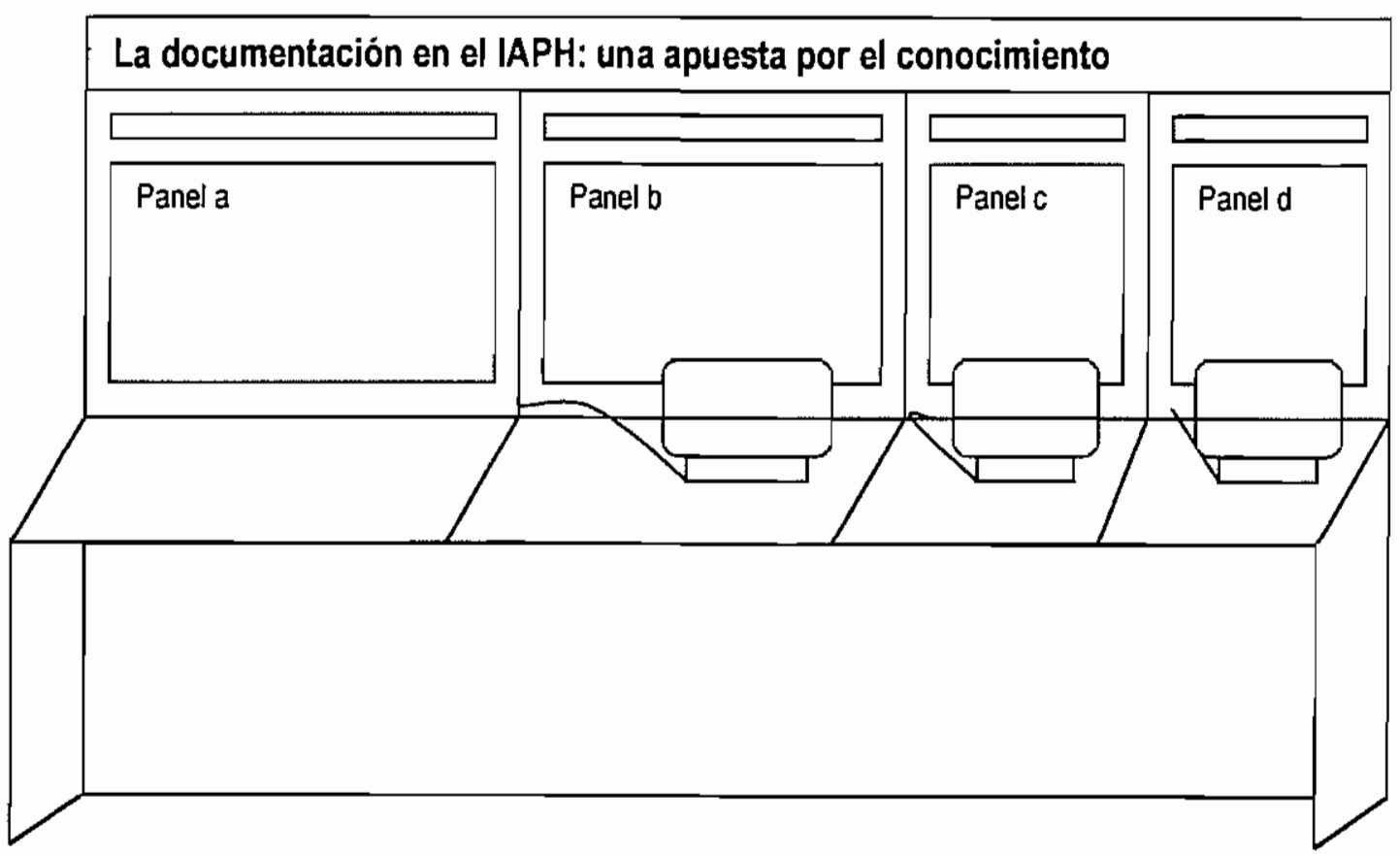

Objeto $\mathrm{n}^{0} 28$ : módulo de paneles y ordenadores de consulta 
Panel a:

Conocer el Patrimonio para actuar posteriomento sobre el es el principio que rigo la actividad del centro do Documentación, siompre plonero en su concepción y proyecóón y hoy uno de los senvicios más valorados de la instituctón.

Lelos de ser un a chivo tradicional, el Centro de Documentacion del IAPH alberga unicantente información, datos sin plantearse en ningún momento la actínulacion o recoglda de or ginalos y documentos lo que so manejo on este Centro es, pues, conocimiento; lo que se gestiona es información, la mas amplia y desariollada información posible sobre e Patrimonio Historico Andaluz

El conjunto de unfomaciones, de bases de datos infomalizadas y rolactonadas entre si se ha denominado siPHA (Sistema de Información del Patrimonio Historico de Andalucia). Hoy, tres departamentos trabajen juntos en el Centro de Documentacion para actualizar y me orar esta infomación del Patrimonio Historico andaluz

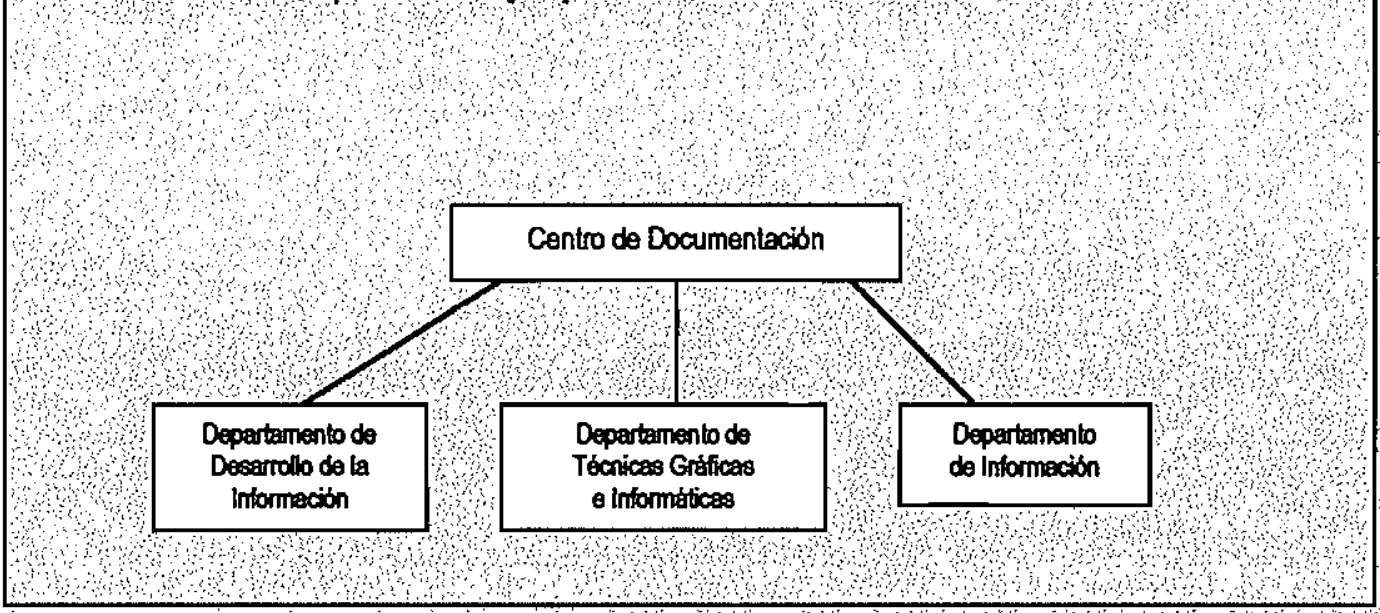


El panel b incluye información oculta que el visitante tendrá que descubrir si desea conocer el contenido o descripción de cada una de las bases de datos que se enumeran. Debajo de las cartelas blancas, aparecerá el siguiente contenido:

- Base de datos de Patrimonio Arquitectónico y Urbano (SIBIA): contiene unos 4.000 registros de información referida al patrimonio inmueble de interés, $y$ en concreto, a los Monumentos, Jardines Históricos y Sitios Históricos de Andalucia.

- Base de datos de Patrimonio Arqueológico (DatARQUEOS): incluye información sobre los yacimientos arqueológicos; y su distribución en el medio fisico de todas las provincias andaluzas. Cuenta con unos 11.300 registros.

- Base de datos de Patrimonio Mueble: con información sobre los bienes muebles andaluces recogidos en el Inventario de Bienes Muebles de la Iglesia Católica en las Diócesis de Cádiz, Córdoba, Granada, Málaga y Sevilla, así como aquellos que se encuentran protegidos. Cuenta con unas 30.000 piezas.

- Base de datos de Patrimonio Etnológico (ETNO): agrupa información de bienes inmuebles de interés etnológico procedente del Inventario de Bienes Etnológicos y otras fuentes, recogiendo diferentes tipologías, como edificios industriales, agropecuarios, viviendas y espacios de sociabilidad. Cuenta con unos 4.000 registros.

- Base de Datos de Información Bibliográfica (BIBLOS): reúne información referencial de monografias, en mayor número, y de artículos de revistas nacionales, relacionada con el Patrimonio Histórico en general y los Bienes Culturales de Andalucia en particular. Con un total de 27.189 registros hasta el momento.

- Base de Datos Documental: por un lado, sobre archivos e instituciones, series documentales y documentos directamente asociados a los bienes culturales del Patrimonio Histórico Andaluz incluidos en las distintas bases de datos sectoriales del IAPH, y por otro lado, la documentación generada por la propia institución.

- Base de Datos Gráfica, que se alimenta fundamentalmente de la producción documental del IAPH, así como de la adquisición proveniente de otros centros. Actualmente dispone de más de 13.000 registros referentes a material gráfico en diversos soportes, principalmente diapositivas, además de negativos y fotografias. 
Panel b:

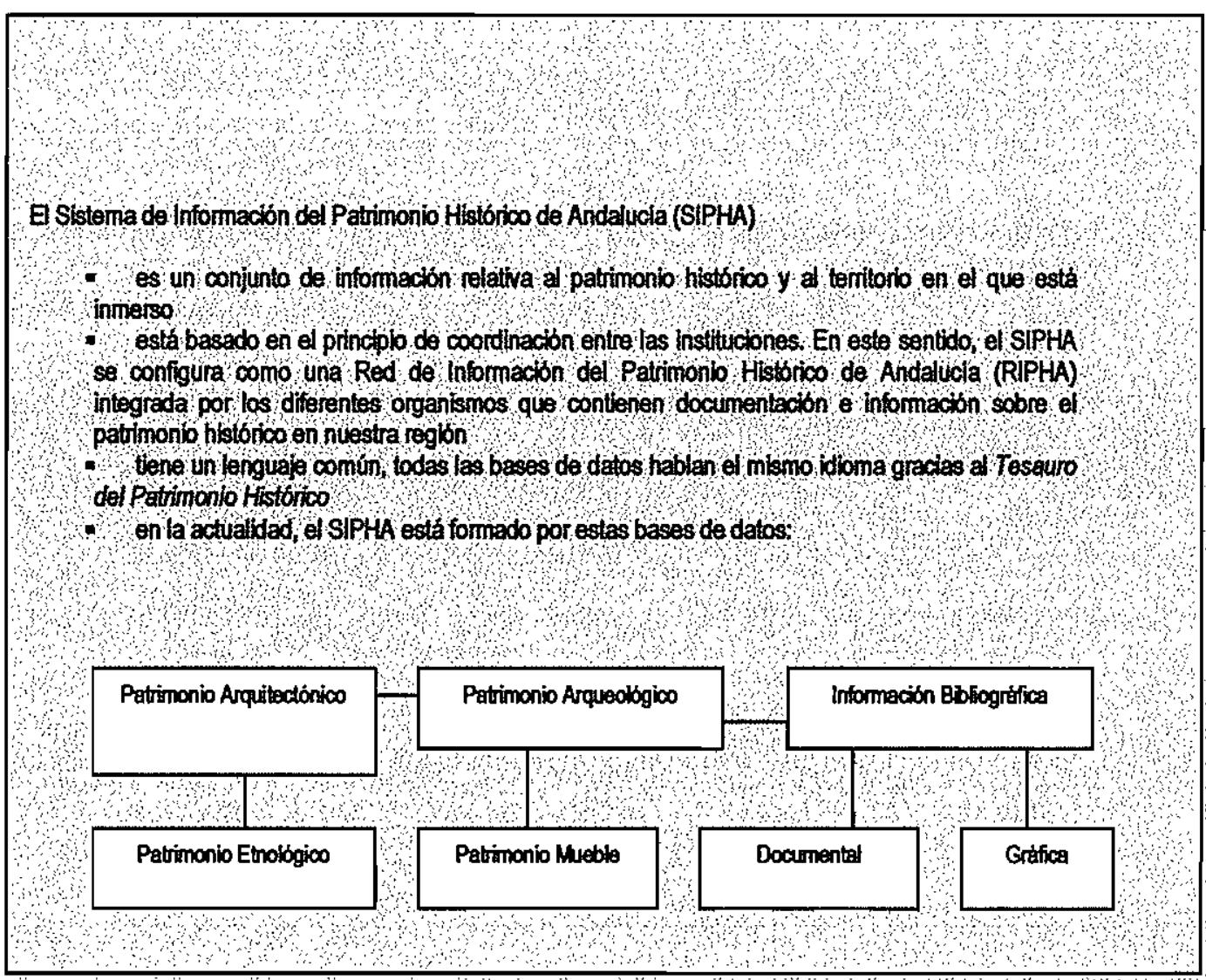


Panel c:

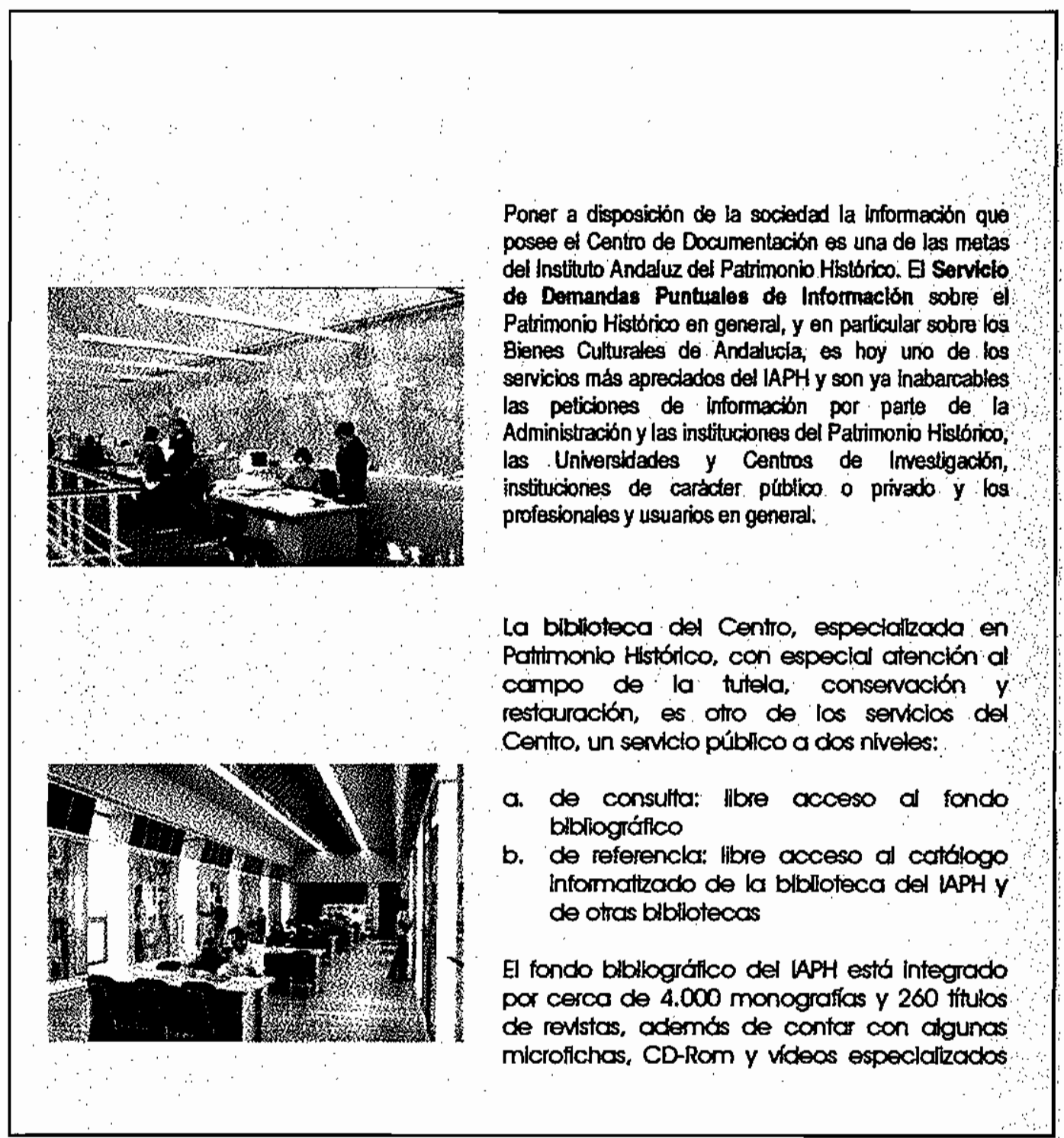


Panel d:

Además de las basos de datos que in gran el Sistoma de lnomacion del Patrimono Histórico (SIPHA) y otros productos de interes como CDRoms temátion, directorios y boletires, el Centro de Doaumentación de IAPH pone a disposición de los usuarios una serie de próductos de informacion en intemet en tre los que destacan algunos itherarios cifturales:

Proyecto Docomomo.

Milag Urban

Clausuras de Cadz

Puedes conocer es tos ilinerarlos en unw laph.junta andalucta esprodcul

Volazquaz vicentenatio

Obviamente, en los ordenadores de consulta del módulo interpretativo se podrá consultar la información correspondiente al panel superior. Así, en el terminal l el visitante del centro podrá conocer el contenido de las bases de datos del SIPHA existente en la red, en el terminal 2 se contemplará la posibilidad de hacer consultas de información vía correo electrónico y de conocer el fondo bibliográfico de la biblioteca y en el terminal 3 se podrá navegar por los itinerarios culturales de la web.

De este modelo concluimos la descripción del módulo interpretativo que ocupa la pared izquierda de la sala dedicada al Centro de Documentación del IAPH. En la pared derecha, como se expuso anteriormente, un mural de fotografias recorre de principio a fin el pasillo. Es el objeto $n^{\circ} 29$. 


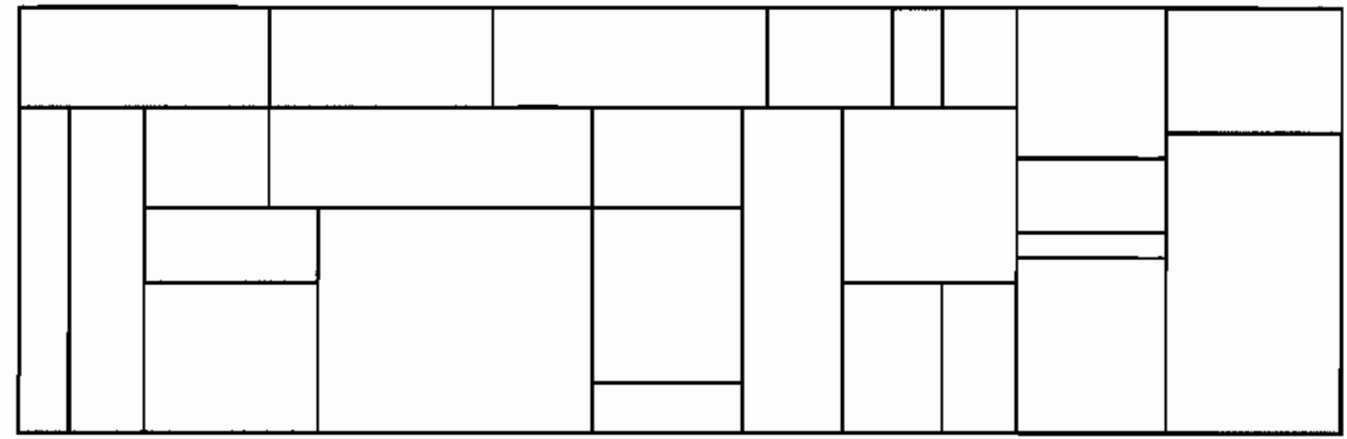

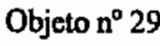

El visitante continúa su recorrido hacia la derecha y accede a un pequeño espacio que hace de introducción al Centro de Intervención. En este espacio se colocará el atril de inicio (objeto $\mathrm{n}^{\circ} 30$ ) -ligeramente a la derecha según se entra- $\mathrm{y}$ una fotografia de gran formato en la pared izquierda (objeto $n^{\circ} 31$ ):

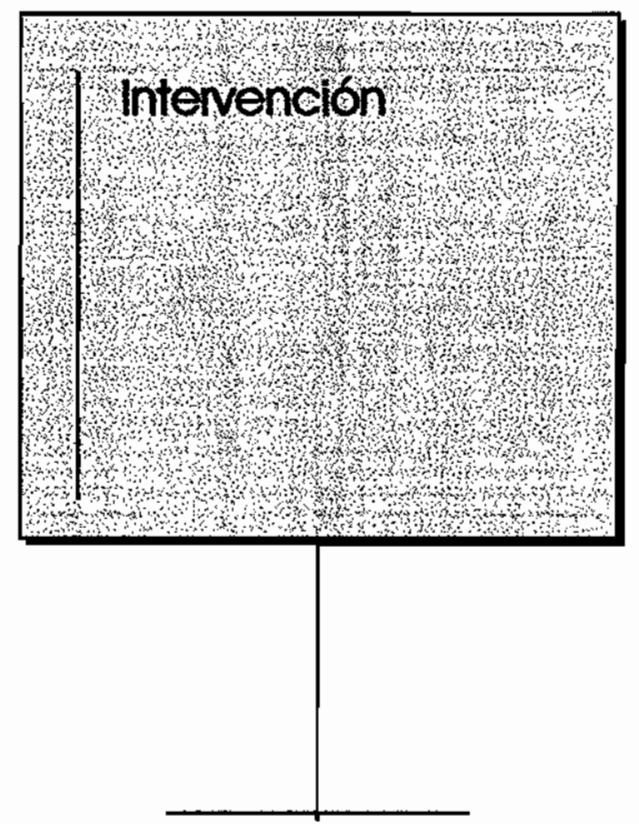

Objeto $\mathrm{n}^{\circ} 30$ : atril introducción intervención 


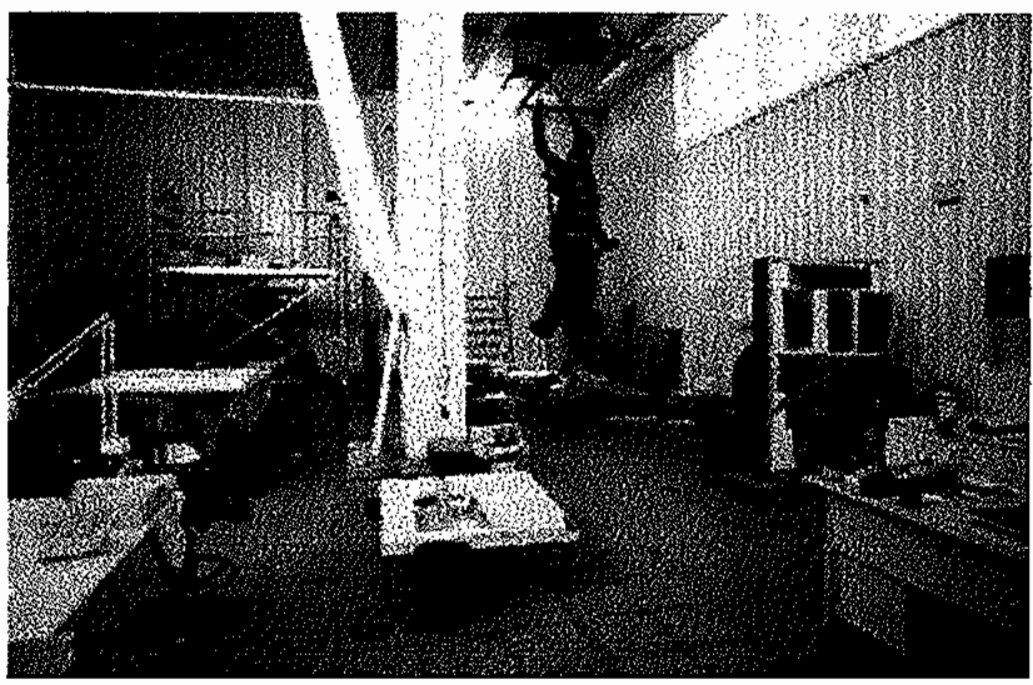

Objeto $n^{\circ} 31$ : fotografia introducción intervención

El área de interpretación del Centro de Intervención -en cruces azules en el planoconsta de tres áreas, la primera y la segunda formando una unidad (caracterizada por contar con entrada de luz natural) y la tercera significando un cambio de sentido. Aprovechando esta doble estructura del espacio, la primera zona se dedicará a cuestiones de investigación y análisis, y la segunda al área de tratamiento.

Entre las cuestiones generales de la intervención en el IAPH, y que el visitante ha de conocer a través del Centro de Interpretación, destacan las relacionadas con la estructura tripartita y multidisciplinar del proceso de intervención (investigación, análisis y tratamiento), metodología propia de trabajo, conservación preventiva, selección de obras... A estas cuestiones intentan dar respuesta las siguientes unidades de exposición, cuyo rasgo común será el fondo de imitación a textura de lienzo. 


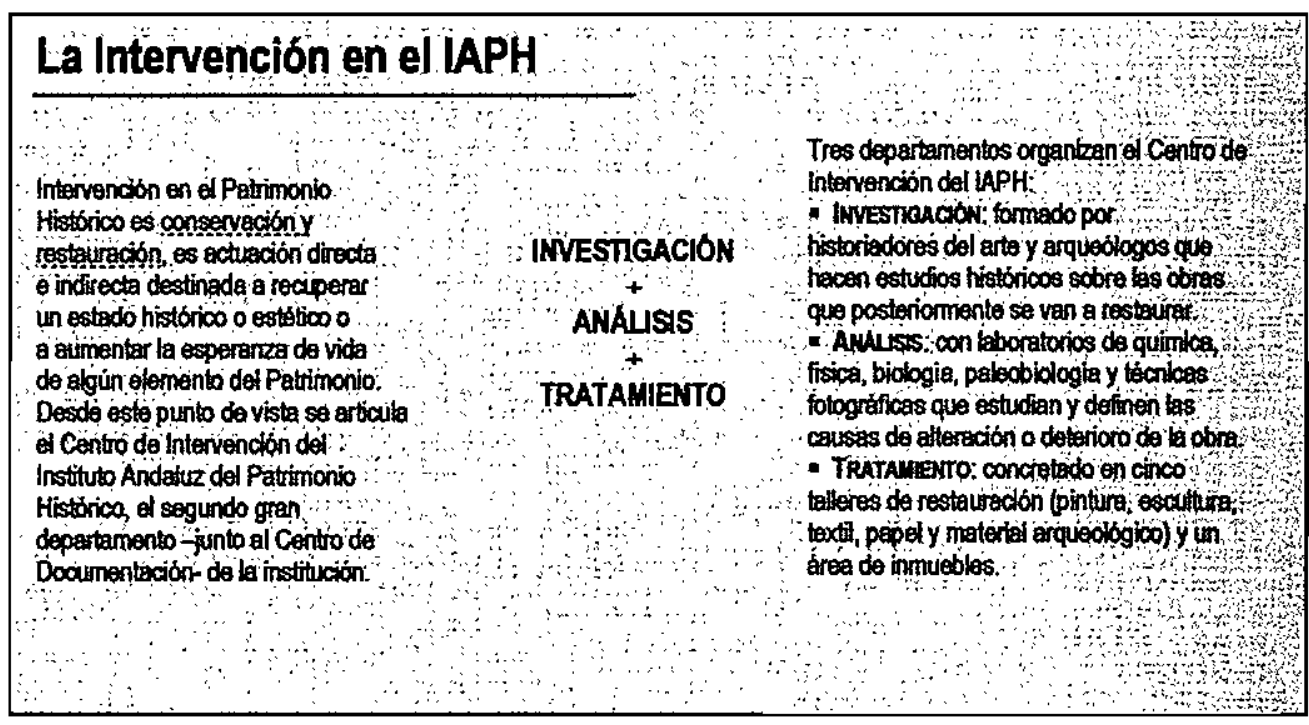

Objeto $n^{\circ} 32$ : introducción intervención

Este panel de introducción se situará en la pared que el visitante se encuentra de frente al entrar en el área iluminada. A la izquierda de este módulo se colocará un panel sobre la investigación en el Centro de Intervención ( $n^{\circ} 33$ ); a la derecha (objeto $n^{\circ} 34$ ), otro panel que intenta explicar qué obras son intervenidas en el IAPH y por qué motivos.

\section{El desarrollo de una metodología propia: investigar antes de intervenir}

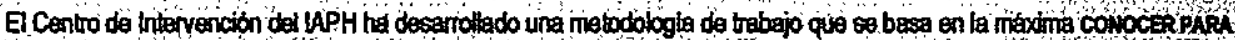

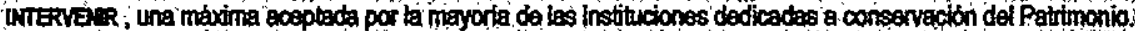

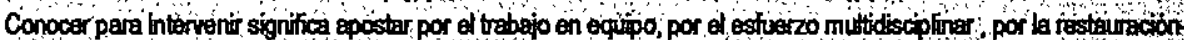
conservación en dos fásos complementerias

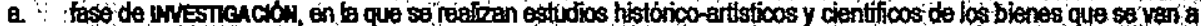
restaver

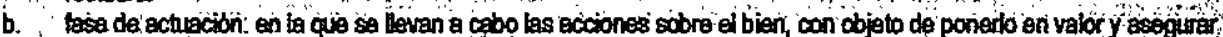
superduebliktad 


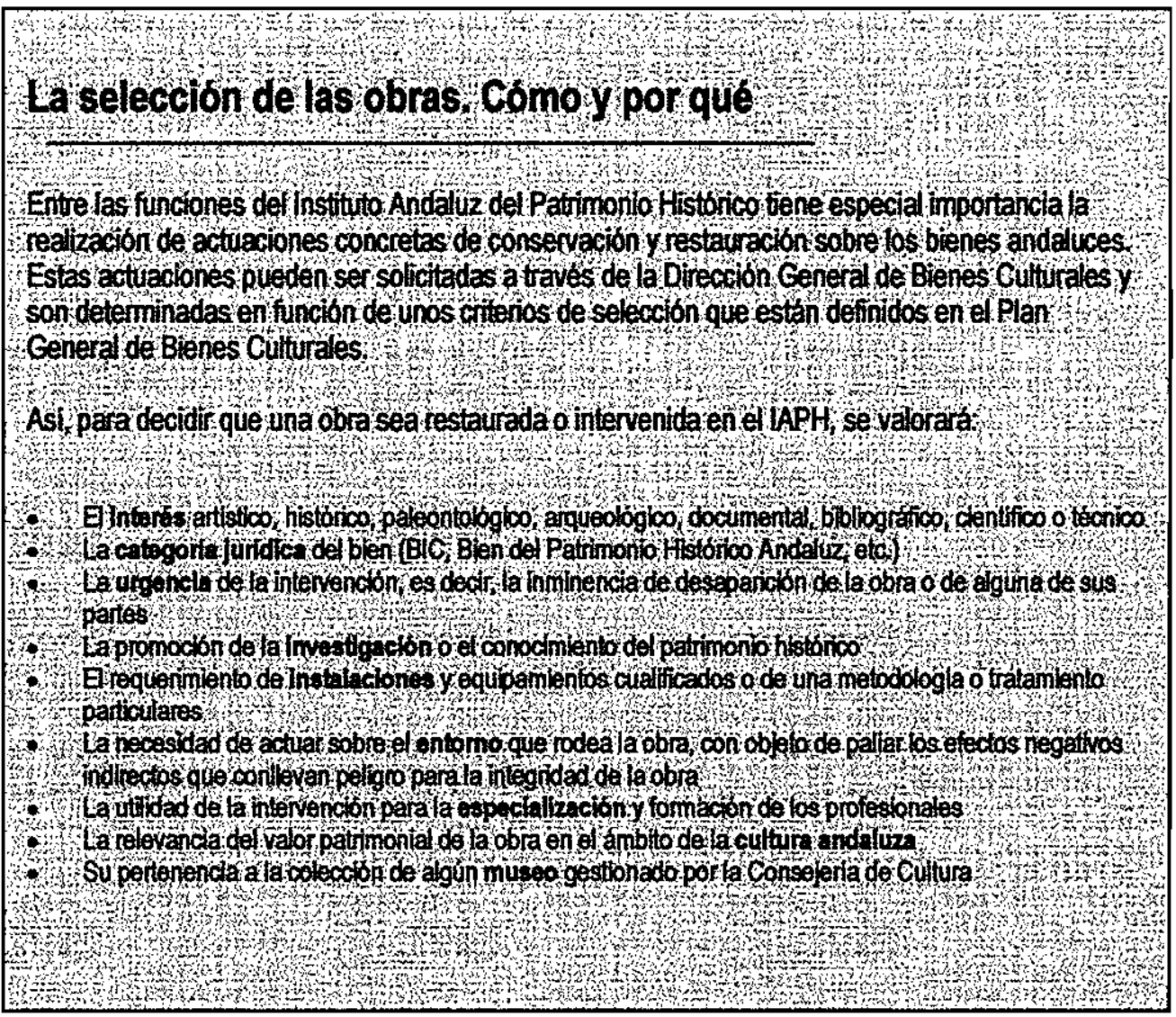

Objeto $n^{\circ} 34$ : criterios de selección

El visitante deja atrás la primera parte dedicada al Centro de Intervención y conecta con la segunda, que cuenta con tres paredes en $U$, de las cuales destaca por su extensión la frontal. Precisamente esta pared se destinará a explicar los laboratorios o áreas de análisis, con algunos textos donde se explica la importancia del estudio cientifico en la diagnosis de alteraciones $y$ en las propuestas de tratamiento o intervención (objeto $\mathrm{n}^{\circ} 35$ ): 

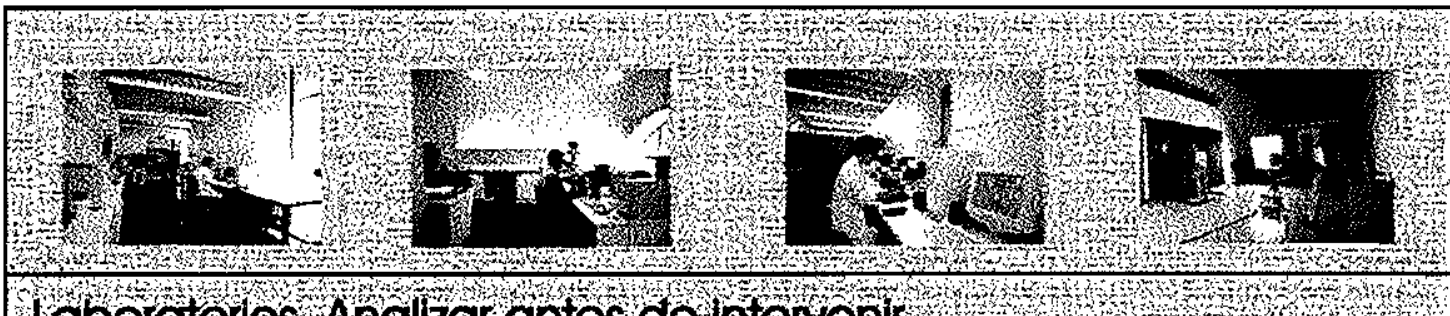

\section{Loboratoilos Analizar antes de inteneni}

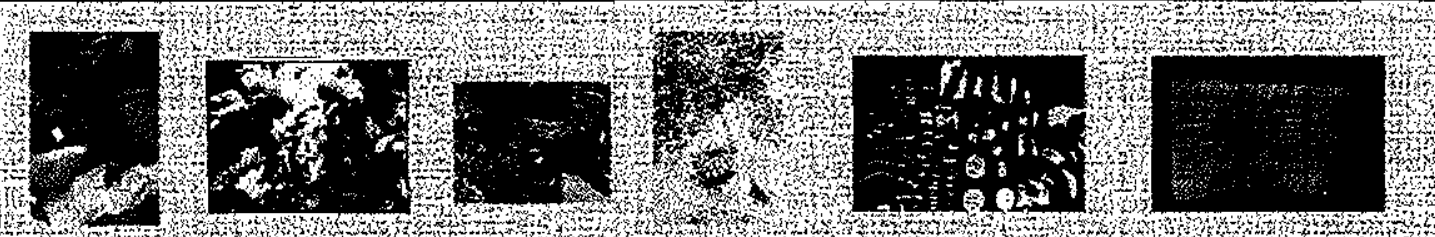

\begin{tabular}{|c|c|c|c|c|c|}
\hline QUIMKA & GEOLOGIA & ISICA & BIOLOGIA & PALOBXOLCA & FOIOGRAFIA \\
\hline 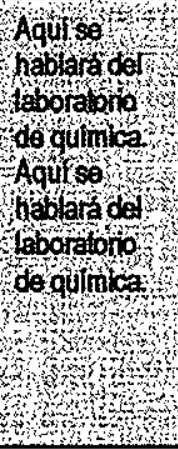 & 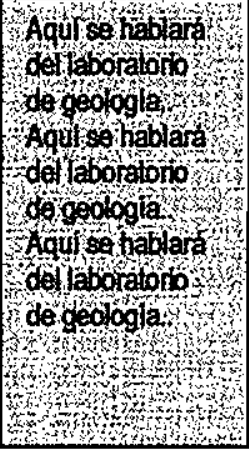 & 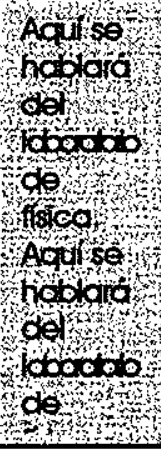 & 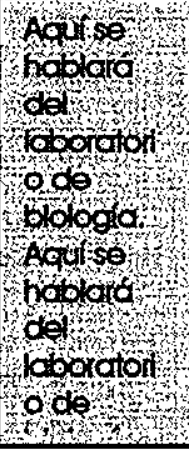 & 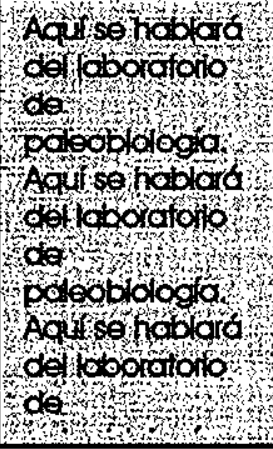 & 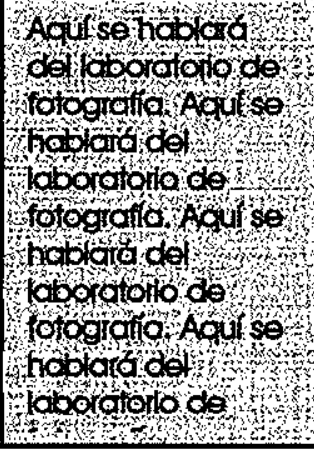 \\
\hline
\end{tabular}

Objeto $\mathbf{n}^{\circ} 35$ : laboratorios

En la esquina de este segundo espacio se situará una pantalla en la que se proyectará un vídeo sobre conservación preventiva (objeto $\mathrm{n}^{\circ} 36$ ), de aproximadamente 5 minutos de duración continuada. En él se describirán las actividades del área de conservación preventiva del Instituto Andaluz del Patrimonio Histórico, así como los fundamentos de esta temática. 


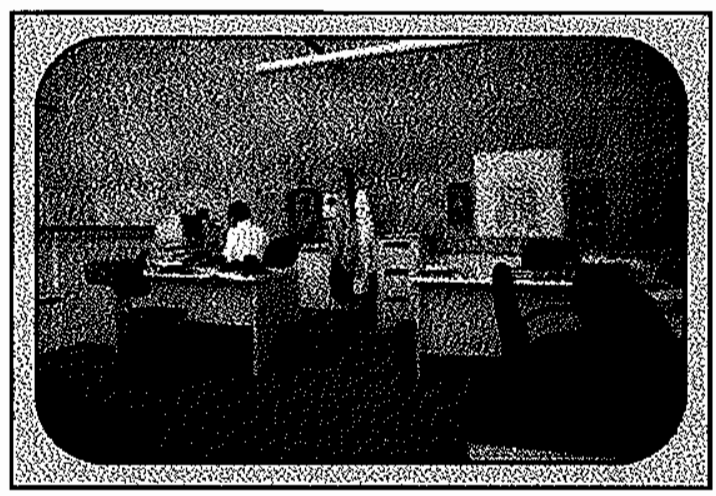

Objeto n³6: video de conservación preventiva

Finalmente, en el tercer espacio dedicado a Intervención, el visitante podrá conocer el área de tratamiento, a través de tres módulos expositivos:

a) panel sobre los criterios de intervención del IAPH (objeto $n^{\circ} 37$ ), en la pared derecha según se avanza

b) mural sobre las diferentes áreas de tratamiento (objeto $n^{\circ} 38$ ), en la pared frontal. En este mural se utilizarán imágenes ilustrativas que sean relativamente familiares ${ }^{12}$ para el visitante, aprovechando "la capacidad de los individuos de traer a la memoria una información visual percibida previamente" (HAMMITT, citado por MORALES, 1999:270) para incrementar la efectividad en términos de comprensión y retención de los mensajes.

c) vídeo sobre grabaciones en talleres (objeto $n^{\circ} 39$ ), en la última pared de aproximadamente 5 minutos y de proyección continus, con grabaciones reales de talleres de restauración ${ }^{13}$ ordenadas, adaptadas y preparadas para el centro de visitantes en función de nuestros intereses, de los contenidos que queremos transmitir.

\footnotetext{
${ }^{12}$ El concepto de familiaridad es un arma interpretativa que hay que utilizar sin exceso, con objeto de no reducir las preferencias y la calidad de la visita (MORALES, 1999:272)

${ }^{13}$ En una primera fase del proyecto se pensó en proyectar imágenes en directo de la actividad en los talleres de restauración, con objeto de cubrir la ausencia de realismo que conlleva un centro de interpretación. Sin embargo, esta posibilidad ofrecía dos problemas: 1) la contrariedad que podía surgir entre los profesionales, acosados por unas cámaras de video permanentemente y 2) la desinformación, pues una cámara en directo no cubre nuestras expectativas, ni de contenido, ni de adecuación temporal. Se conseguiria, en definitiva, una granhermanización innecesaria
} 


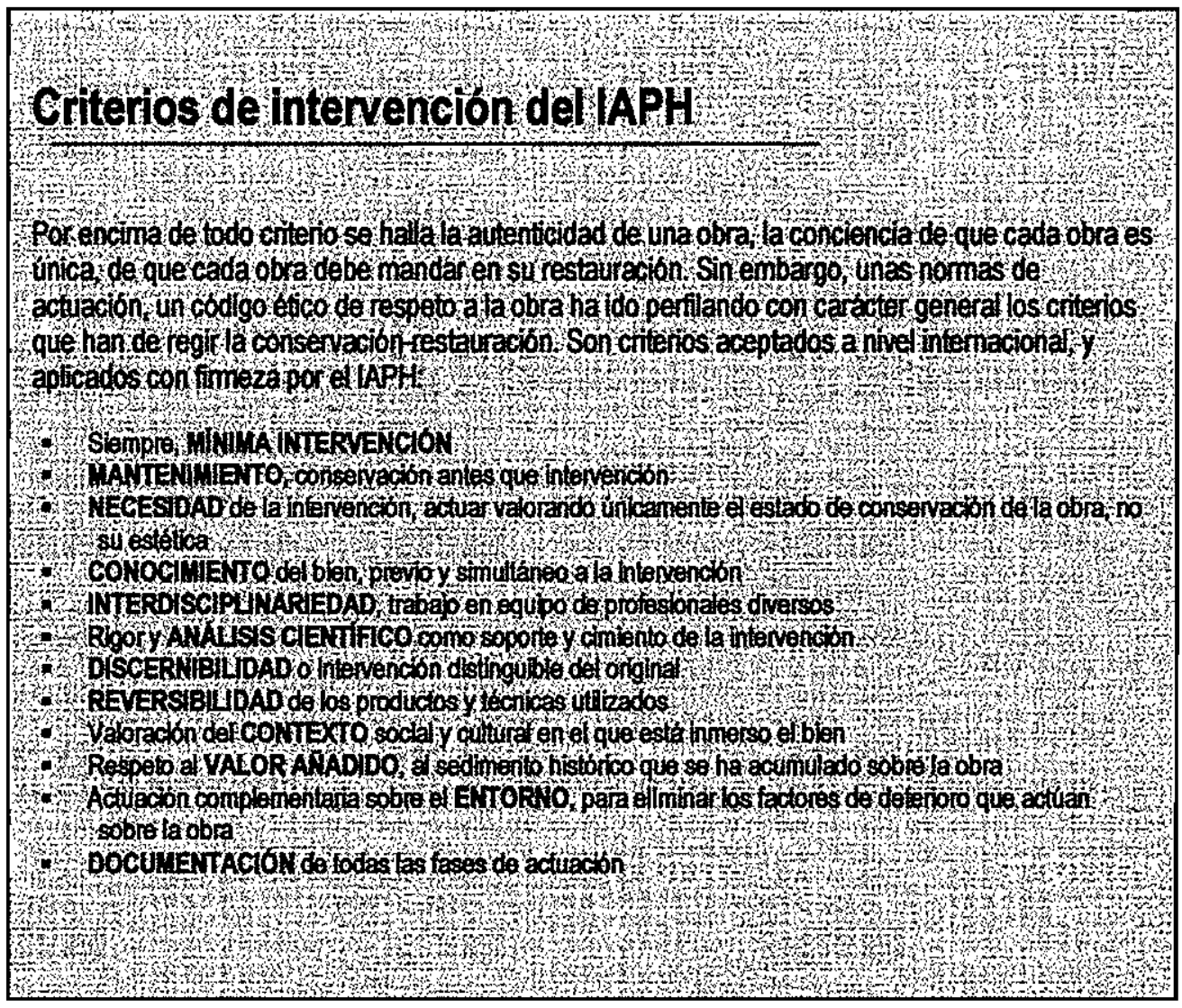

Objeto $n^{\circ} 37$ : criterios de intervención 


\begin{tabular}{|c|c|c|c|c|c|}
\hline Wholy & 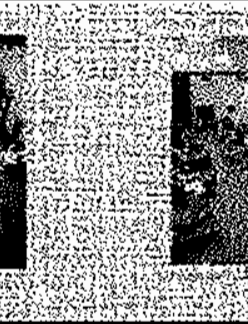 & 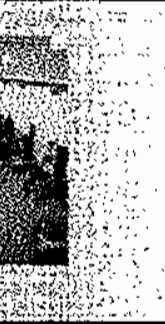 & $\begin{array}{l}\ddots \\
\cdots \\
\cdots \\
\cdots\end{array}$ & $\therefore$ & 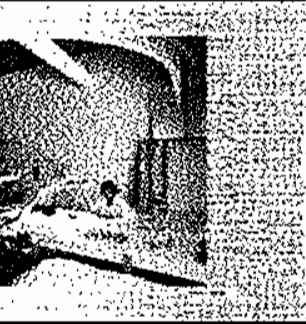 \\
\hline 9.1 & $\alpha \alpha$ & 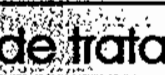 & to & $\therefore$ & \\
\hline (1) & 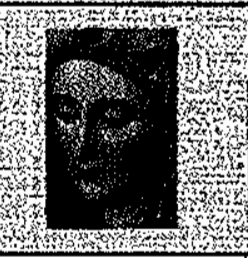 & $\frac{5}{4 x}$ & r. & $\therefore$ 变 & 16 \\
\hline PINTURA & ESCULTURA & TEXTL & PAPEL & ARQUEOQGiA & INMI \\
\hline 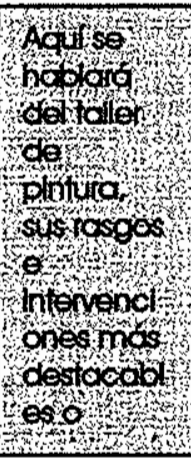 & 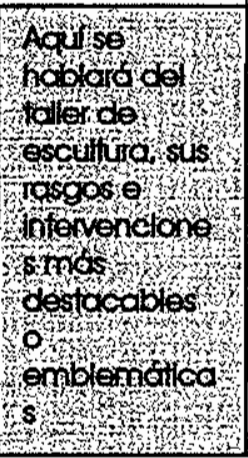 & 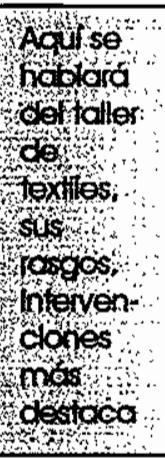 & 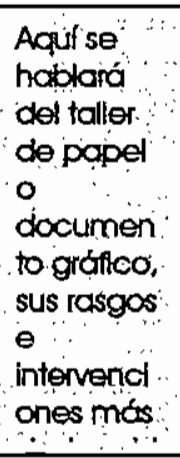 & 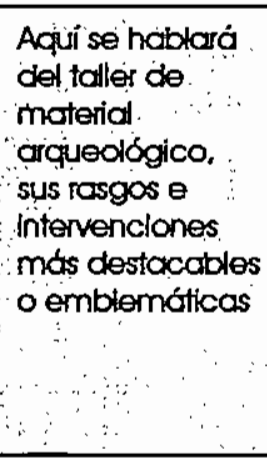 & 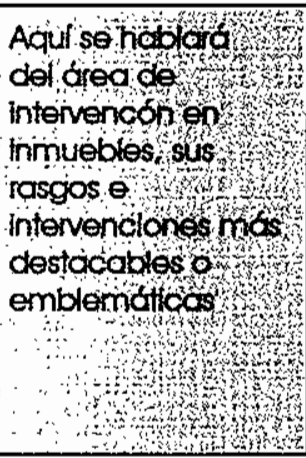 \\
\hline
\end{tabular}

Objeto $n^{\circ} 38$ : talleres

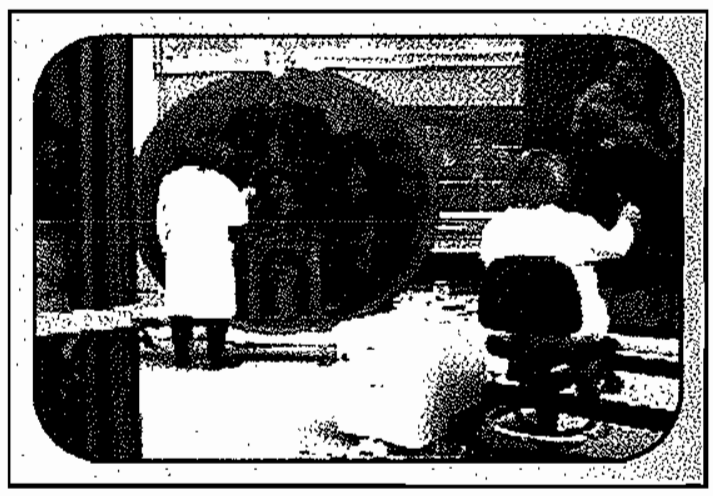

Objeto $n^{\circ} 39$ : video de talletes 
Finalmente, la última sala, destinada a las áreas de Formación y Comunicación (señalada en plano con cruces rojas), se define como una zona de conexión entre el recorrido principal y la instalación de arte del patio, aprovechando las connotaciones de transferencia, de implicación y de relación con la sociedad, de puente con el público que posee el contenido de esta última zona. Como las funciones y productos de Formación y Comunicación, este espacio es intermedio entre el IAPH (investigación, documentación e intervención) y el exterior.

La zona es una especie de pasillo final hacia el Circulo del Patrimonio, con dos paredes laterales, que presentan diversa información. En el suelo se bosquejará una flecha de dos puntas -una de ellas inmersa en la parte anterior de Intervención, la otra en la salida hacia el patio- que simbolizará la interrelación, la conexión entre el IAPH y la sociedad a través de los dos departamentos mediadores, horizontales y transversales de la institución: Formación y Comunicación. El visitante tendrá que pisar por encima de la flecha, en la que estarán escritas palabras como sensibilización, transferencia, difusion, formacion, comunicacion, función social, etc.

El itinerario acaba, entonces, con los siguientes módulos de exposición:

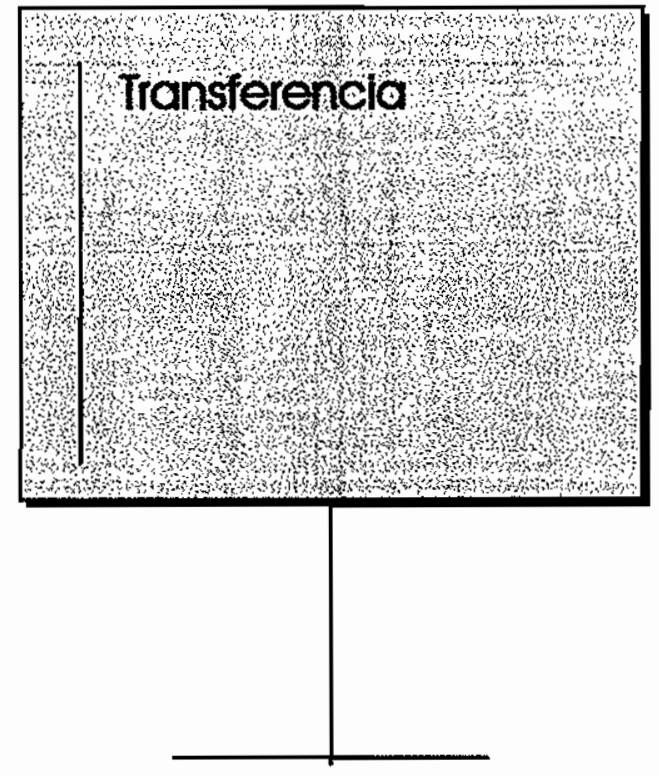

Objeto $n^{\circ} 40$ : introducción Formación/Comunicación 


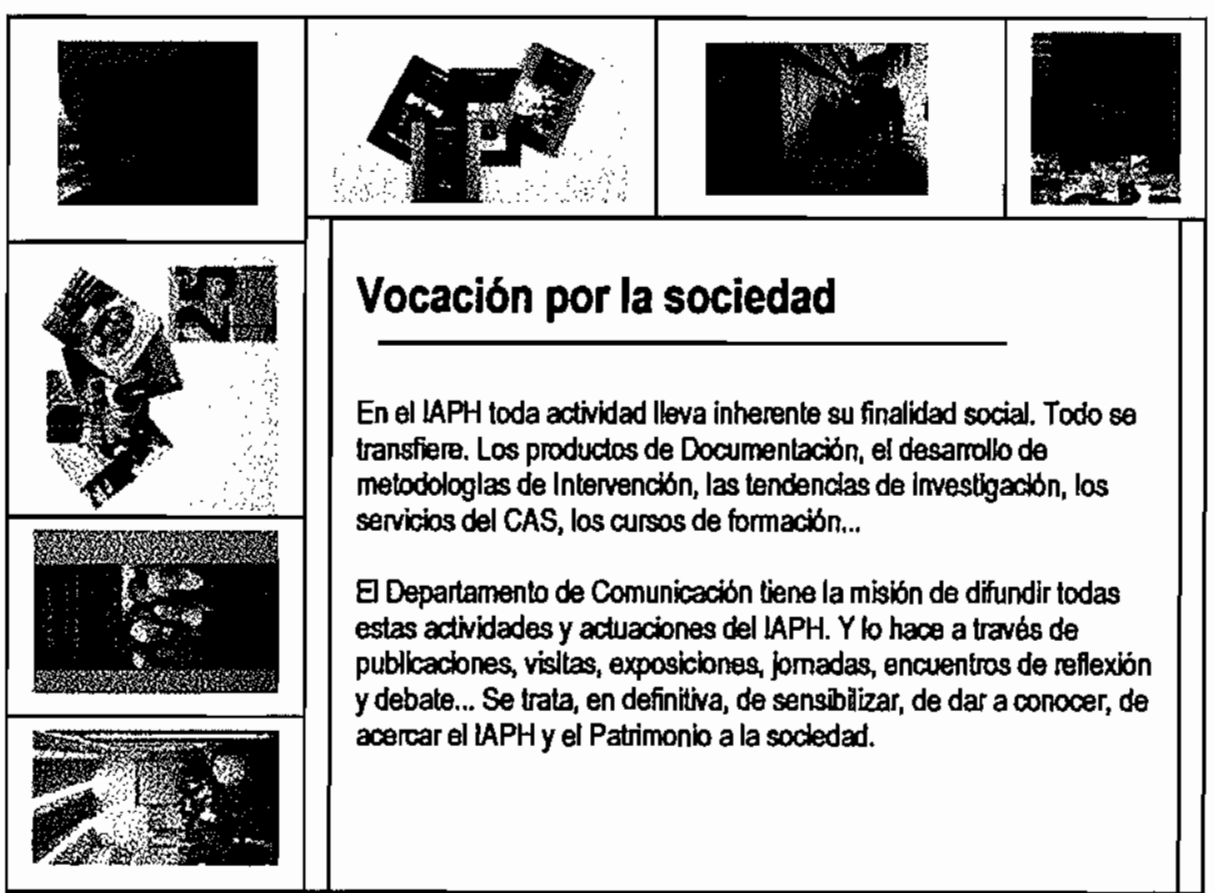

Objeto $n^{\circ} 41$ : presentación Comunicación 


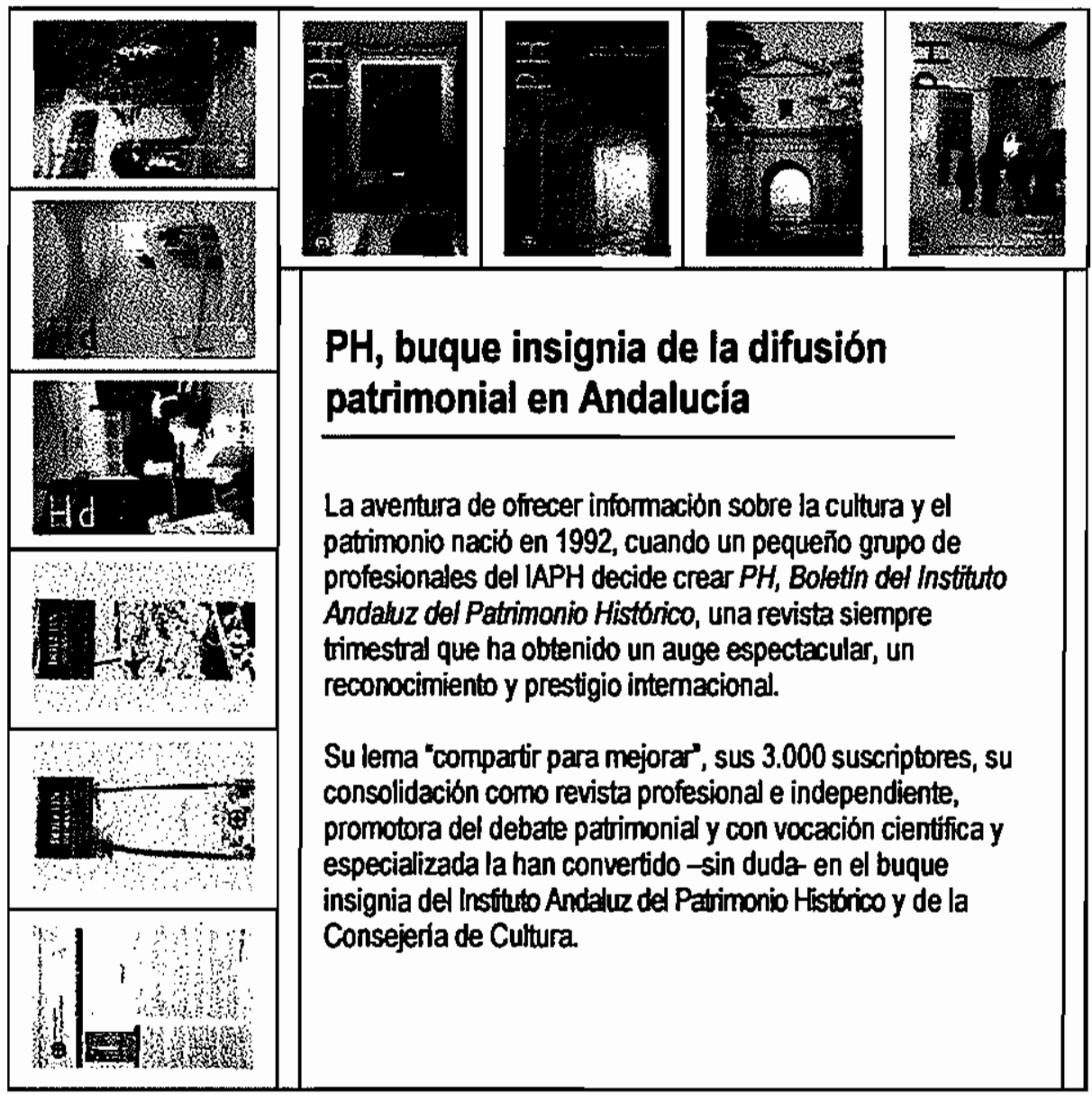

Objeto $\mathrm{n}^{\circ} 42$ : Boletin 


\section{Tres líneas de formación}

El área de Formación del IAPH tiene como objetivo el perfeccionamiento técnico y cientfico de los profesionales del Patrimonio Historico en Andalucia, de los que trabajan dentro y fuera de la administración de Cultura, mediante la organización de:

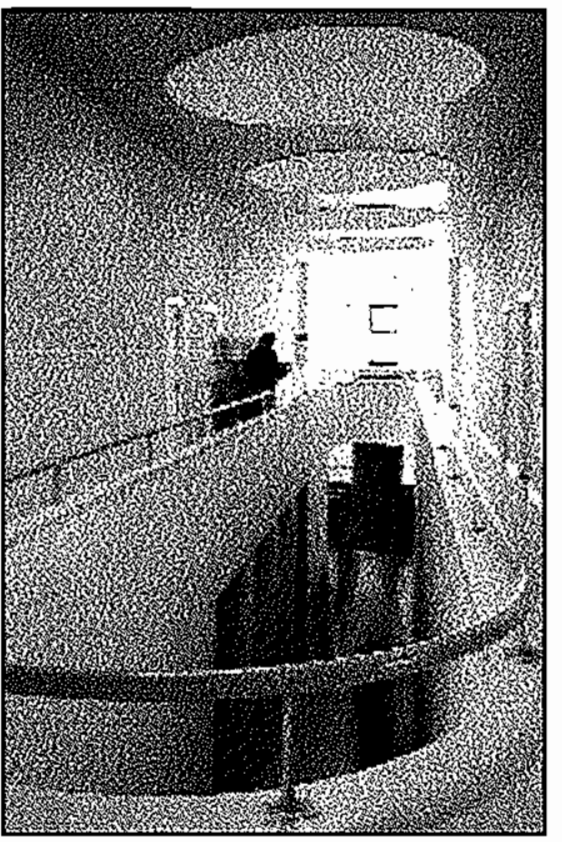

- MAsters o cursos de posgrado

Aqul se ira irctuyendo la actualidad formativa de la oferta de másters organizados por et área de formación del IAPH.

- Cursos de especialización

Aqui se irà incluyendo la actualidad formativa de la oferta de cursos organizados por el área de formación del $\mathrm{LAPH}$

- Becas de formación en el LAPH

Aqui se irá incluyendo la actualidad formativa sobre becas convocadas por el LAPH.

Objeto n ${ }^{0}$ 43: Formación 
El último panel del recorrido expositivo, antes de salir al patio en el que se encuentra El Circulo del Patrimonio será:

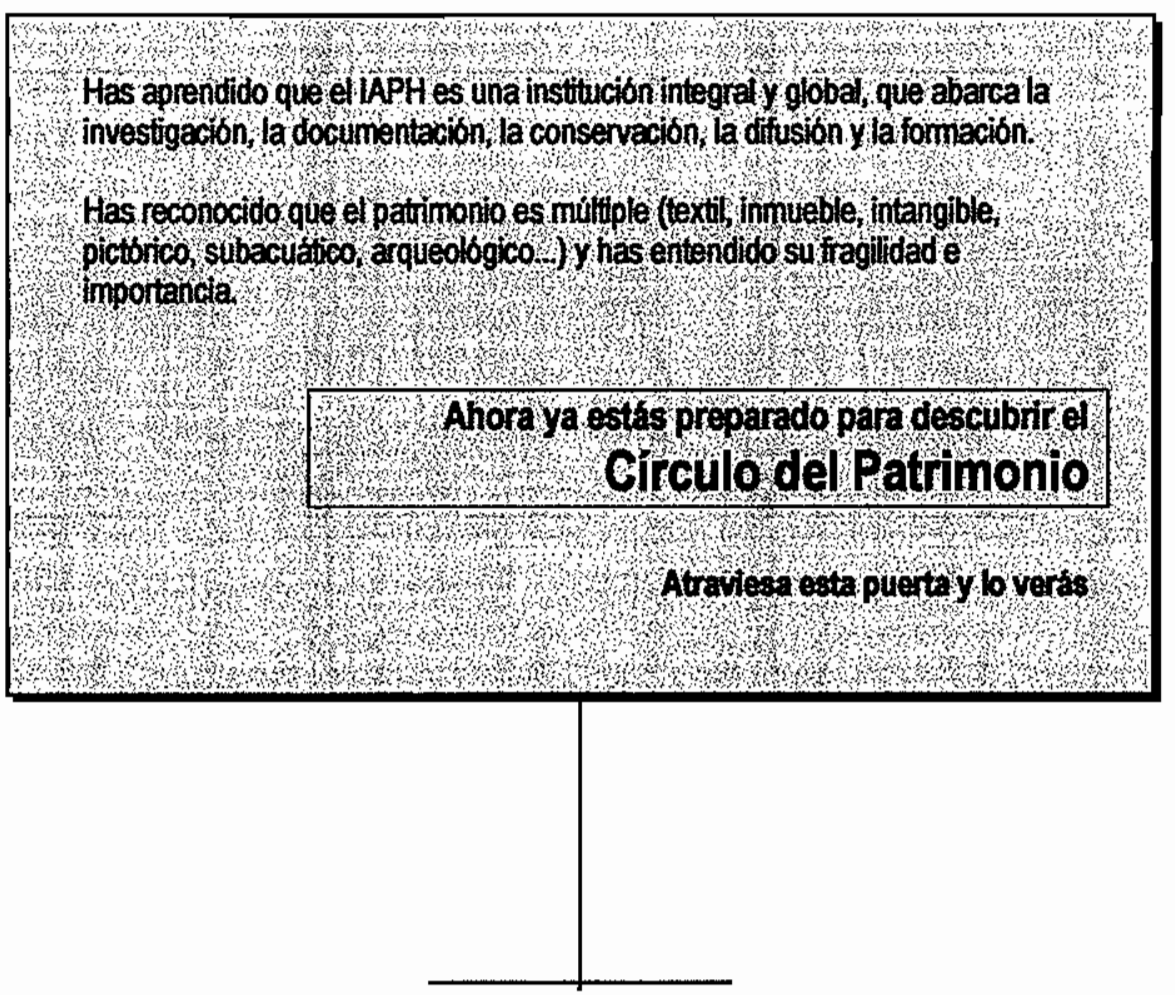

Objeto $n^{\circ} 44$ : Introducción Circulo

La pasión es el ingrediente indispensable para una interpretación poderosa y efectiva. Con estas palabras tan elocuentes, Larry Beck y Ted Cable definían uno de los 15 principios de la interpretación (MORALES, 1999:52). Con pasión hemos querido acabar el recorrido de este centro de visitantes que estamos formulando, con pasión y emoción, con la emoción del descubrimiento de algo trascendental. El visitante cruza la puerta y se encuentra con El Circulo del Patrimonio, con una metáfora del patrimonio, con un símil de la realidad patrimonial. Sintesis de todo bien cultural y de cualquier perspectiva que lo abarque, El Círculo es la unidad expositiva que lo resume todo, es la unidad en si misma. El uno y el todo. El todo y el uno.

Y como no hay materia que trascienda lo trascendental mejor que la materia artizada, proponemos que este último módulo expositivo sea realizado por un artista contemporáneo, que sepa hacer confluir las globalidades, multiplicidades, 
circularidades que -hemos ido viendo- caracterizan el Patrimonio. Una obra de arte contemporáneo, pues, que sirve de colofón de un recorrido más o menos complejo. como compleja es la realidad del IAPH, del patrimonio y de todas las disciplinas que lo rodean. Atracción en sí misma, pieza de museo, esta obra concederá a la institución más carisma del que ya -es obvio- posee.

Efectivamente, se está planteando la posibilidad de hacer el encargo de una instalación a un artista de más o menos renombre con los siguientes requisitos: 1) la obra ocupará la mayor extensión posible del patio (su tamaño ha de impactar), 2) será de materiales resistentes a las inclemencias del tiempo, ya que estará permanentemente al aire libre, 3) deberá ser plana, es decir, se construirá al ras del suelo, de modo que el visitante la vea en su totalidad desde una plataforma alrededor de la obra que estará a $1,5 \mathrm{~m}$. de altura y 4) habrá de sintetizar los contenidos anteriormente expuestos y responder sugerente y eficazmente al título El Círculo del Patrimonio (objeto $\mathrm{n}^{\circ} 45$ y último).

A continuación dibujamos algunos bocetos que podrían sugerirse al artista:

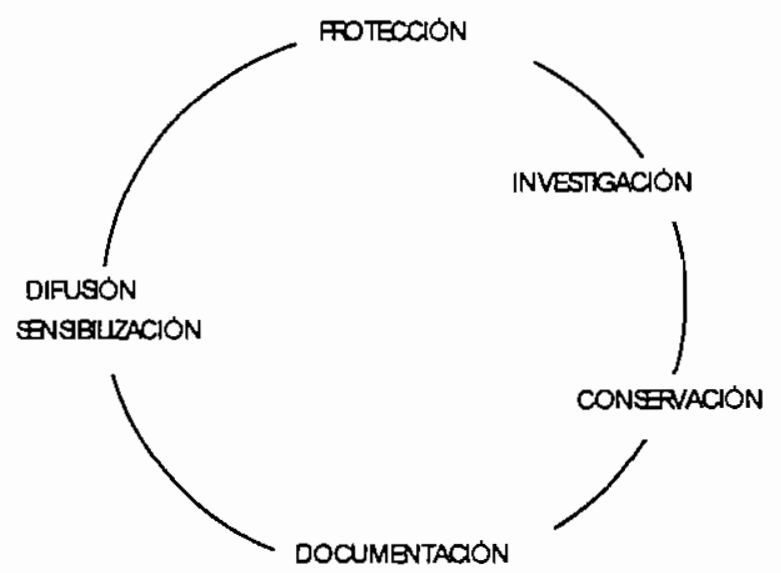




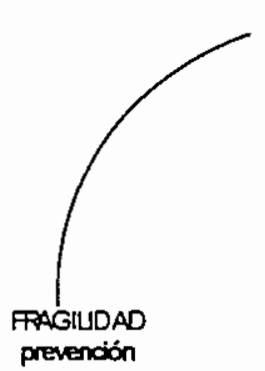

EXISTEZCAA

previsión

PATRMONIO

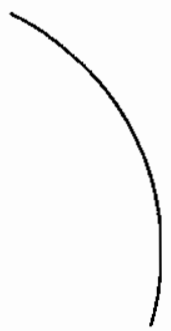

IMPORTANCIA

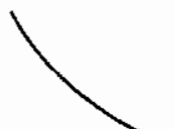

giveación

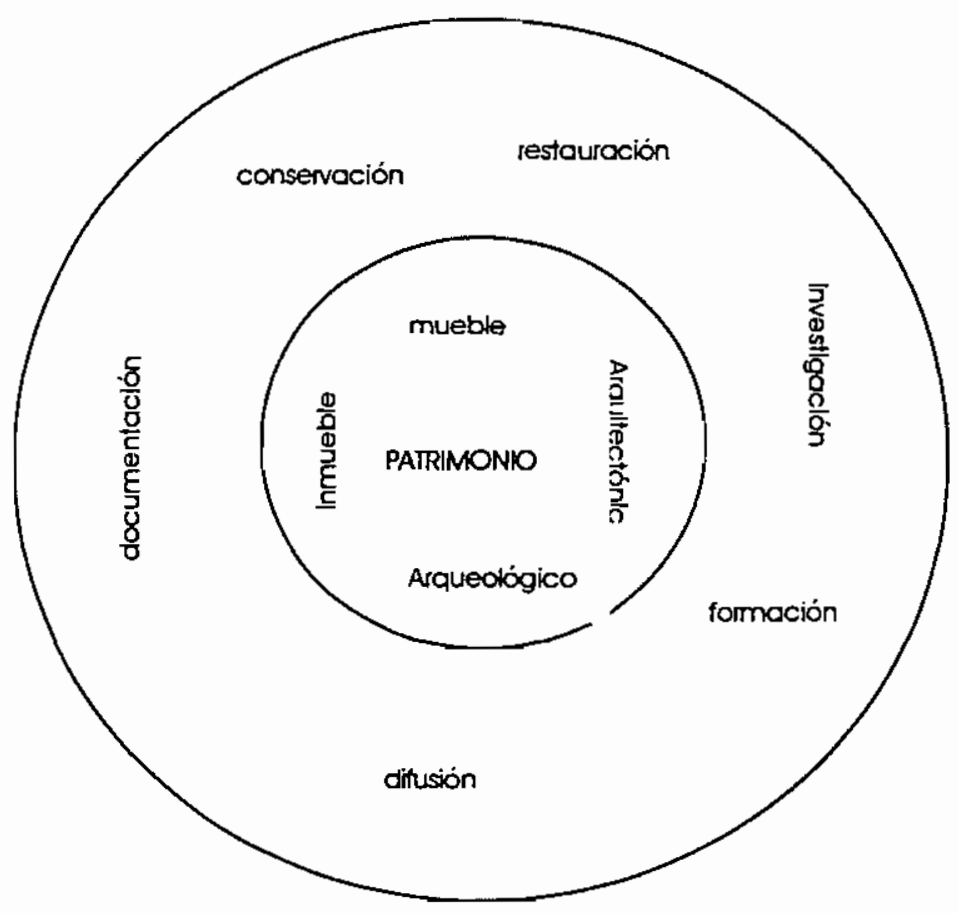


En el recorrido por eI patio, alrededor de la instalación y a $1,5 \mathrm{~m}$. de altura, habrá un cartel -antes de llegar a la esquina de giro- haciendo referencia al segundo punto de contemplación de este Centro de Interpretación: las chimeneas de los hornos de cerámica del siglo XIX que se divisan desde el patio. Las fotos de abajo reflejan esta imagen de las chimeneas y el patio central del que hablamos:
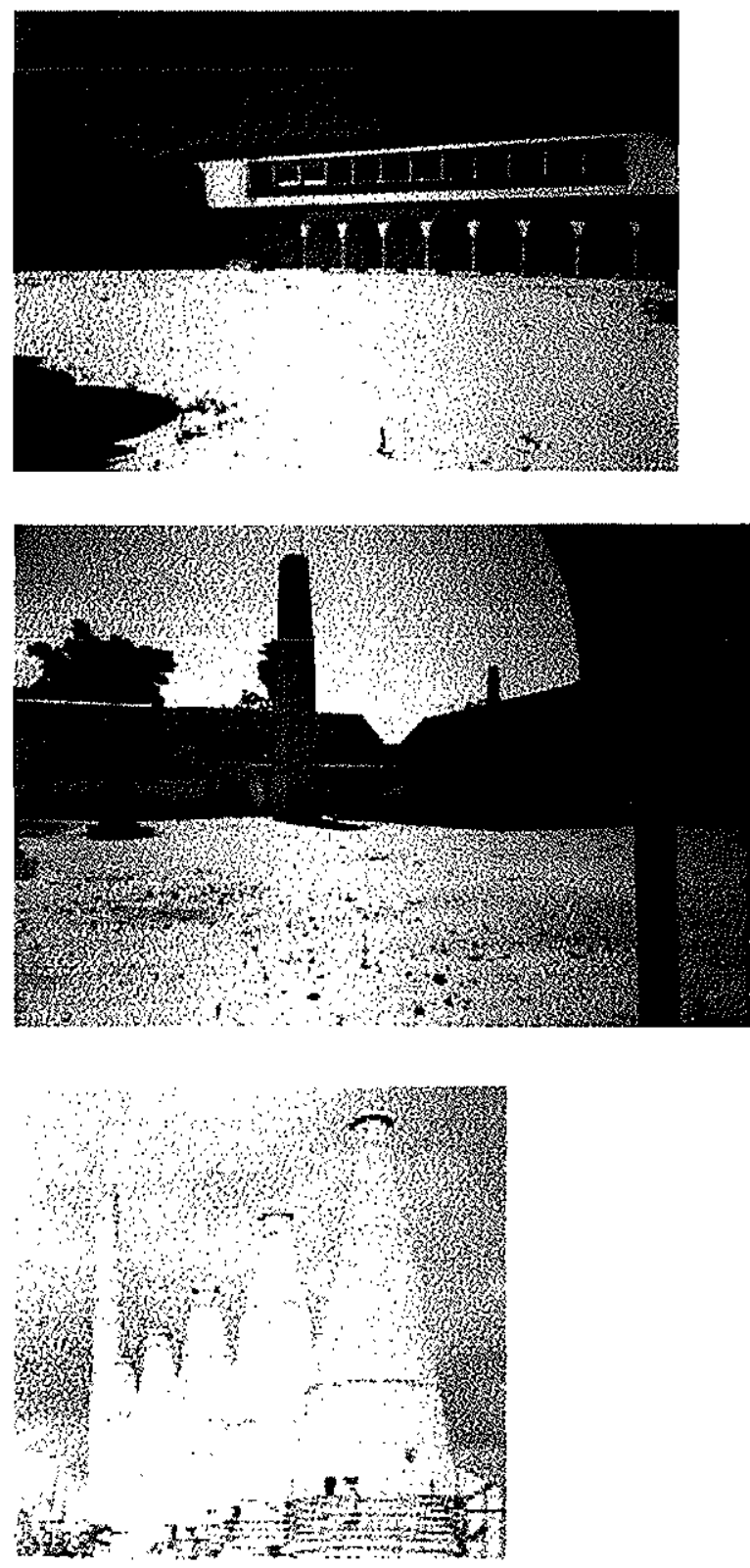
A continuación, el visitante llega (por una puerta entre la hiedra que se ve en la foto anterior) a la celda de legos que se ha habilitado como tienda-librería. Esta celda de legos es el tercer punto de contemplación; se colocará un cartel indicativo y brevemente explicativo del lugar en el que se halla el visitante. Saliendo de la tiendalibrería se continúa hacia la izquierda (este sentido estará señalizado con una flecha), camino de la cafetería.

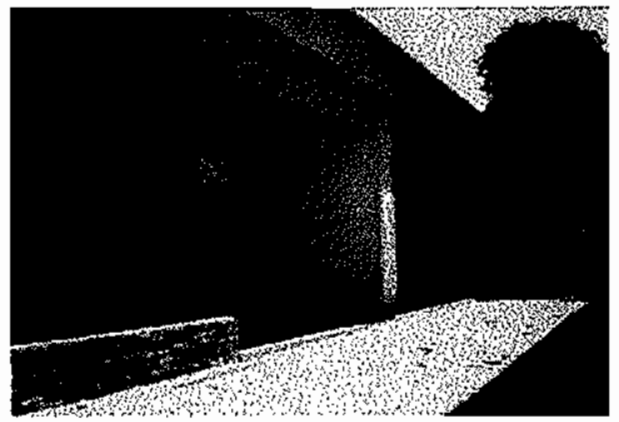

En este pequeño trayecto final, desde la celda de legos a la cafetería el visitante podrá ver un fragmento de la realidad que ha visto interpretada a través de las cristaleras de los taileres de textil que se van dejando a la derecha. En la siguiente fotografia se muestra una de las cristaleras:

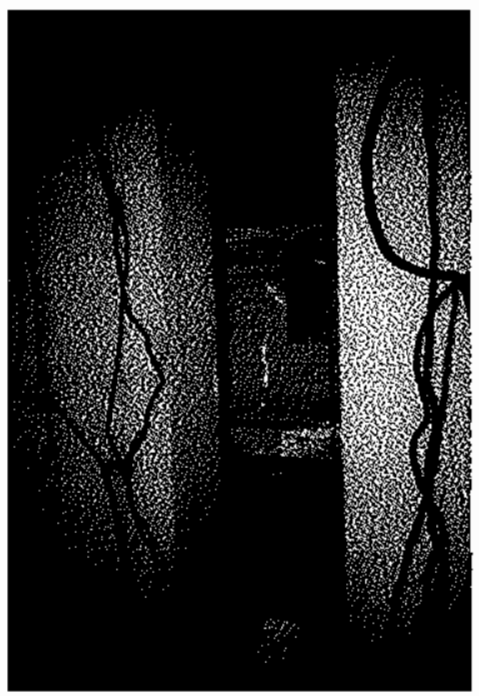

La cafetería, por fin, pondrá punto y final, y descanso, a este recorrido explicativo que se ha elaborado para el público no especializado que desea conocer el Instituto Andaluz del Patrimonio Histórico. 


\subsubsection{PROYECTO DE ILUMINACIÓN}

\section{Las verdades de la huz y de la sombra traducen la} realidad de las casas y de las seres humanos

(CURT BAUER)

El proyecto de iluminación del Centro de Interpretación se vertebra en dos apartados, según la naturaleza de los objetos expuestos. Por un lado, se definirá la iluminación para los módulos expositivos del recorrido del Centro; por otro, la iluminación para las obras reales (últimas intervenciones, habitualmente) expuestas en salas de exposición temporal. Lógicamente será en este segundo apartado donde encontremos mayores escollos, al ser la luz -natural o artificial-gran enemiga de la conservación de las obras, que, de otra parte, requieren de la iluminación para ser contempladas.

Dos claves, moderación y control, dominarán nuestro proyecto de iluminación. En palabras de ZITNIK, 1985:

La iluminación de los objetos tiene que efectuarse de forma discreta y moderada. En este caso hay que observar los principios de la dirección de luz. Hay que aumentar gradhalmente el estímilo del visitante con una determinación adecuada de iluminancia y su dispersión como también el color de la luz (...) Requisito para una planificación de iluminación con éxito es que la luz incida de forma controlada en las salas. Sólo asi se podrá stuperar el problema de transición de la huz diurna la huz artificial

En el recorrido principal del Centro se utilizará un foco de luz tipo Erco (modelo Jilly Spotlight) en las unidades expositivas que estén más aisladas. Cuando sea posible se usarán rieles de focos de luz tipo Erco (modelo Minirail Spotlight):

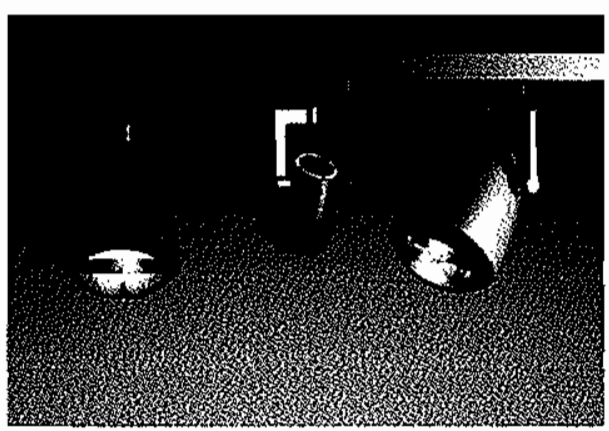




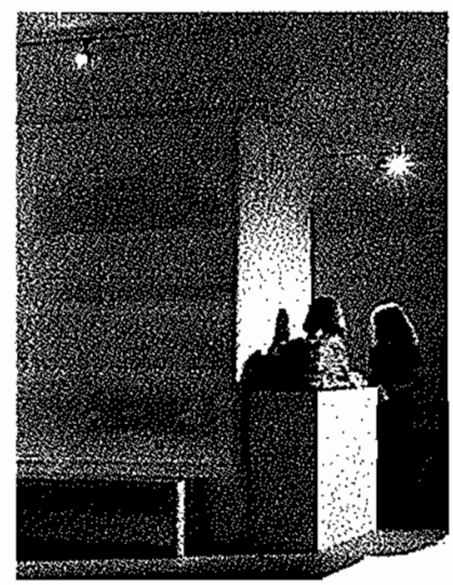

En general se utilizará luz fluorescente en forma de campana y de tipo "luz día", la más cercana a la luz natural. Para evitar la sensación de cansancio o artificiosidad, se intercalarán rieles de luz incandescente en tonalidad de amarillo también cercana a la luz natural. La potencia de las bombillas será generalmente entre 100 y 150 vatios y la distancia con el objeto será de 3 m.(BARBOSA, 1993).

En lo referido a obras intervenidas expuestas (área de exposiciones temporales) se aplicará la iluminación con extremo cuidado y control, siguiendo las normas de conservación preventiva expuestas en el apartado 5.3. (Control de iluminación) e intentando encontrar una satisfactoria vía de compromiso que supere el contraste existente entre las expectativas del público y la actitud justamente prudencial de los conservadores y museógrafos (BAGLIONL, 1999:52).

Según las directrices del $1 \operatorname{COM}^{14}$ (1971), se iluminarán con tubos fluorescentes, de temperatura de color entre 4.000 y $6.000 \%$, con lámparas incandescentes o spots los bienes menos sensibles a la la luz ${ }^{15}$, como metales o esculturas no policromadas; sólo se superarán los 300 lux para destacar un punto en concreto del objeto. Los objetos muy sensibles (acuarelas, textiles, dibujos...) no serán nunca iluminados con luz diurna; la radiación ultravioleta se suprimirá totalmente por medio de filtros. Se podrán utilizar tubos fluorescentes de temperatura de color de unos $2.900^{\circ} \mathrm{K}^{16}$. Por último, e] resto de objetos (pinturas, maderas...) se iluminarán -entre 150/180 lux-con tubos fluorescentes de $4.000^{\circ} \mathrm{K}$ que no emitan radiación ultravioleta.

\footnotetext{
${ }_{14}^{14}$ Citadas por BAGLION, 1999:57

${ }^{15}$ también se admite luz diuma controlada

${ }^{16}$ como regla general no se superarán los 50 lux. Ver especificaciones en apartado de Control de iluminación
} 


\subsubsection{SALAS DE EXPOSICIONES TEMPORALES}

El área de exposiciones temporales del Centro de Interpretación del Instituto Andaluz del Patrimonio Histórico se sitúa en el ala izquierda del Callejón del Aire, según se avanza hacia la entrada principal de la institución, en la zona justamente inferior a la biblioteca del IAPH.

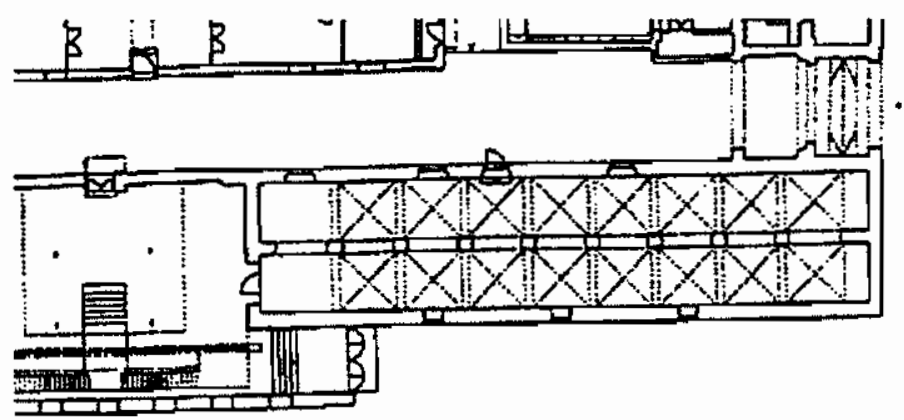

Este espacio, que es compartido al 50\% con el área de talleres didácticos, es apto y muy adecuado para la realización de exposiciones ${ }^{17}$ por múltiples motivos:

- Estéticamente es ideal para la observación de las obras. Se trata de un área diáfana, blanca, con arcos del siglo XIV que prometen un espacio de silencio, reflexión, contemplación.

- La diafanidad es también una gran ventaja para la exposición de objetos, para establecer un diálogo entre contenido y continente sin perturbar el protagonismo de la obra expuesta.

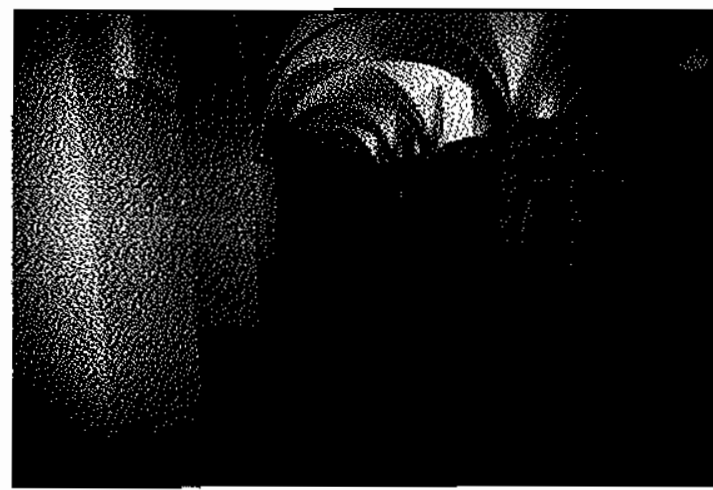

${ }^{17}$ como se verá más adelante esta sala se utilizará principalmente para realizar exposiciones de las intervenciones que se vayan terminando en el IAPH, antes de que las obras vuelvan a sus lugares de origen 
- El área de exposiciones cuenta con dos puertas, de modo que se podrá permitir cierta agilidad entre los visitantes, al destinar una de ellas (en el hall) como entrada y la otra, a salida (hacia el callejón). Provisionalmente, para exposiciones muy visitadas, se podría habilitar la puerta habitual de entrada del IAPH para organizar los flujos de visitantes.
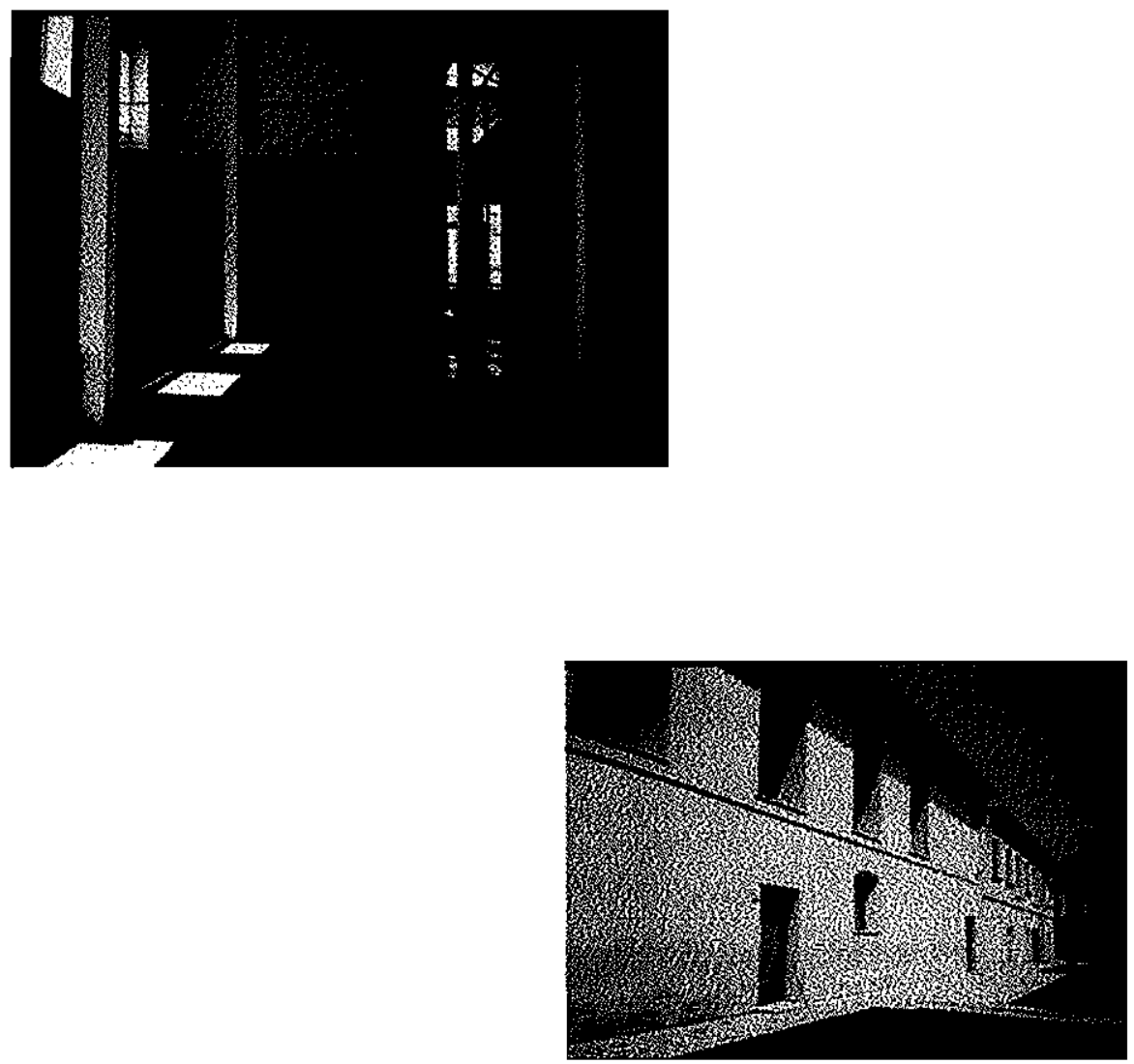

- El tamaño del espacio $\left(115 \mathrm{~m}^{2}\right)$ es adecuado para exponer una o dos obras, es decir, el tamaño se adecua a las necesidades de la institución.

- En un espacio cercano hay bancos (en el hall) y áreas al aire libre para descansar (jardines). 


\subsubsection{ALMACENES}

Los almacenes del Centro de Interpretación no tienen un carácter estrictamente museológico, debido a la inexistencia de colección. Tampoco es necesario el almacenaje de las obras que vayan a ser expuestas temporalmente -las recientes intervenciones- puesto que está previsto que éstas pasen del taller a la sala de exposición directamente. Así, los almacenes del centro tienen un sentido de depósito de materiales.

Los elementos didácticos de talleres escolares, así como de los módulos expositivos del recorrido del centro de visitantes y otros utensilios y herramientas para exposiciones y equipos de mantenimiento serán guardados en los depósitos del IAPH, concretamente en el depósito del Departamento de Comunicación (de $30 \mathrm{~m}^{2}$ ) que se halla en los sótanos y se utiliza en la actualidad como almacén de publicaciones y paneles expositivos. Se utilizará igualmente para guardar reservas de productos de cafeteria y de publicaciones de venta en librería. Enfrente de este almacén se encuentra el montacargas / ascensor, que facilitará el traslado y acarreo de los materiales.

\subsection{4. ÁREAS DE SERVICIOS PARA EL PÚBLICO GENERAL}

Las áreas de servicios para el público general son:

- CAFETERÍA: se trata de una cafetería autoservicio, con máquinas para café y para aperitivos. Se colocarán cinco mesas y veinte sillas. También habrá tres papeleras grandes. La cafetería se encuentra en la zona destinada para ello en el proyecto original del edificio.

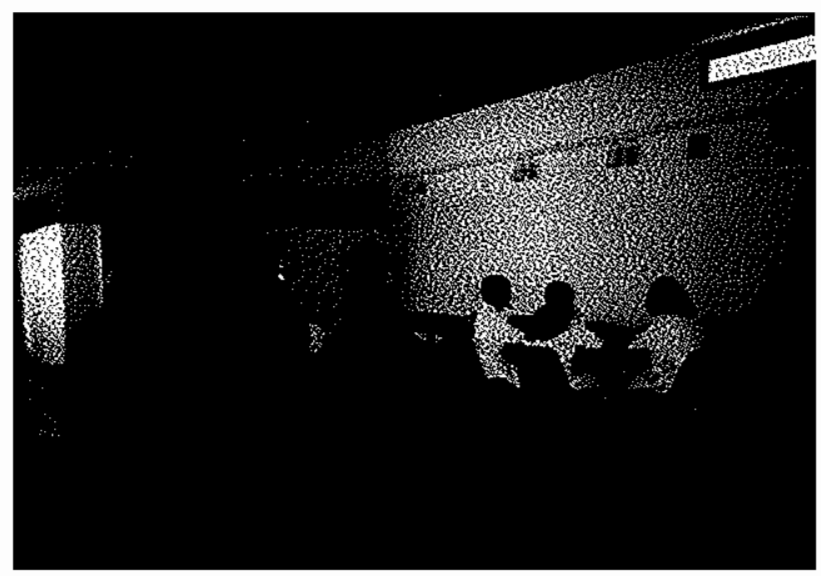


- TIENDA-LIBRERÍA: situada en una de las celdas de legos, la tienda contará con un expositor para publicaciones, un mostrador y dos sillas. Además de la venta, se ofrecerá la posibilidad de realizar suscripciones a la revista Boletín $P H$.

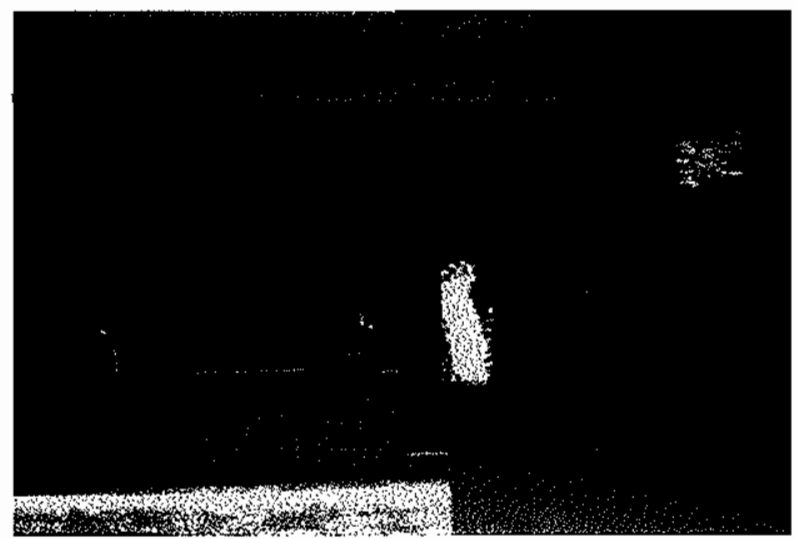

- ASEOS: el conjunto del Centro de Interpretación dispone de un aseo en el recorrido principal y otro en la cafetería.

- ESPACIOS DE DESCANSO: además de los bancos o asientos situados en el hall de entradá en el propio recorrido (área de introducción, zona aseos y área dedicada a sede), en la tienda y la cafetería, se cuenta con el área de jardines del Monasterio. 


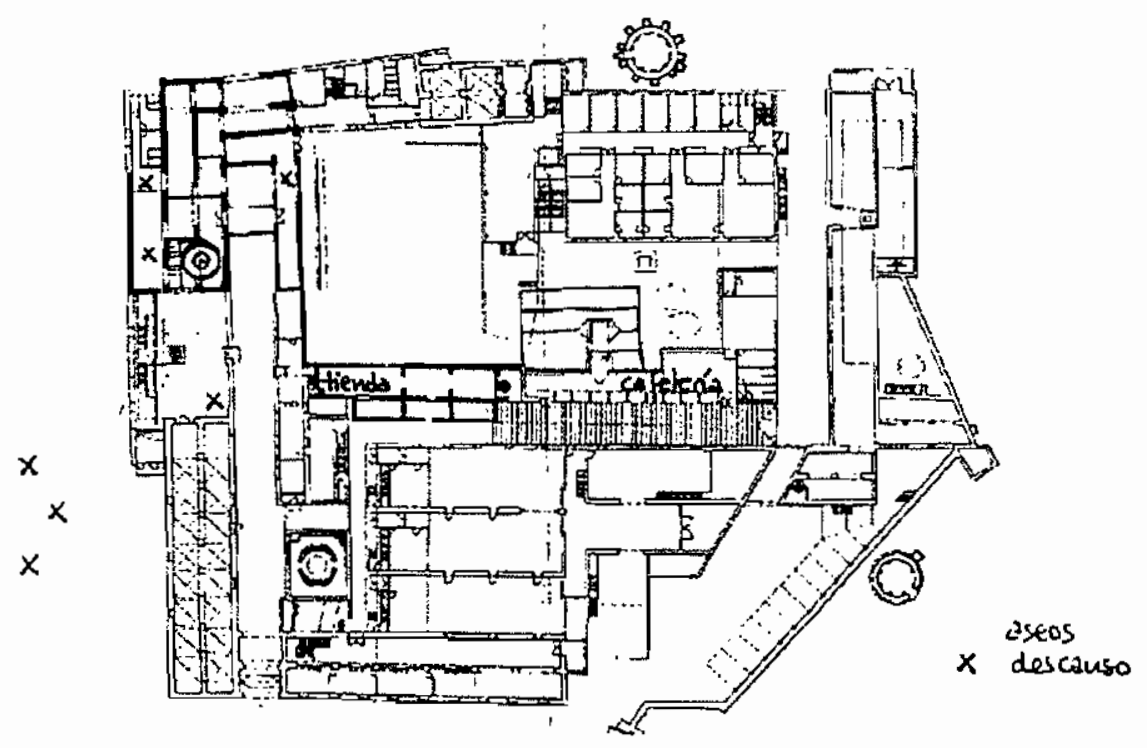

Plano de ubicación de áreas de servicios para el público general

\subsection{5. ÁREAS DE SERVICIOS PARA EL PÚBLICO ESCOLAR}

Específicamente, las áreas de servicios para el público escolar se concentran en la zona destinada a talleres didácticos, que se halla situada al lado del espacio para exposiciones temporales y tiene acceso independiente de las demás áreas del Centro de Interpretación. Este espacio -que se utilizará también para cursos de formación o talleres pedagógicos de aprendizaje para profesores o para charlas informativas sobre el tipo de ayuda que pueden recibir, asi como los materiales y equipos didácticos disponibles- contará con iluminación artificial, pupitres para 20 personas ( 5 bancos de 4 asientos), dos pizarras y corchos para colgar en paredes.

Las zonas de jardines serán un área de servicio para el público escolar, tanto para descansar como para tomar alguna consumición, ya que es habitual que los grupos escolares deseen aprovechar la visita Monasterio/CAAC/IAPH. Los autocares que transportan a los grupos escolares, por otra parte, cuentan con amplias zonas de aparcamiento en el exterior. 


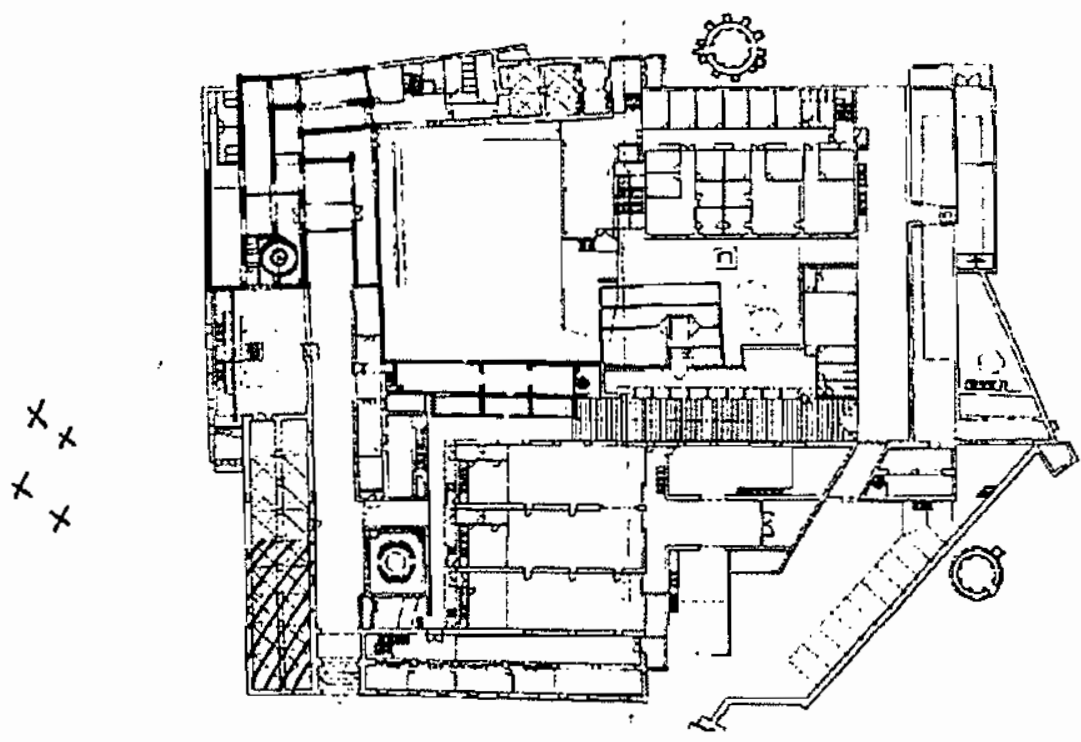

Plano de ubicación de áreas de servicios para el público escolar

\subsection{6. ÁREAS DE SERVICIOS PARA EL PÚBLICO ESPECIAL}

De un modo particular y privativo, para las personas con discapacidades físicas, no existen áreas de servicio específicas, a excepción de los dos aseos que se situarán uno en el recorrido del Centro de Interpretación y otro en la cafetería. No obstante, todas las áreas definidas en el apartado 3.5.4. (áreas de servicio para el público general) están habilitadas para que puedan ser utilizadas por el público con discapacidad fisica o dificultades motóricas.

\subsection{7. ÁREAS DE SERVICIOS INTERNAS}

En el Departamento de Comunicación del IAPH se sitúan las oficinas del Centro de Interpretación, en las que desarrollan sus tareas laborales el responsable del centro y los responsables de exposiciones temporales, talleres didácticos e investigacióndocumentación. Estas cuatro personas dispondrán de cuatro mesas, cuatro sillas y dos ordenadores.

Por otro lado, en el Edificio A se habilitara una zona para guías y voluntarios, donde podrán reunirse o depositar sus pertenencias y materiales de trabajo. 


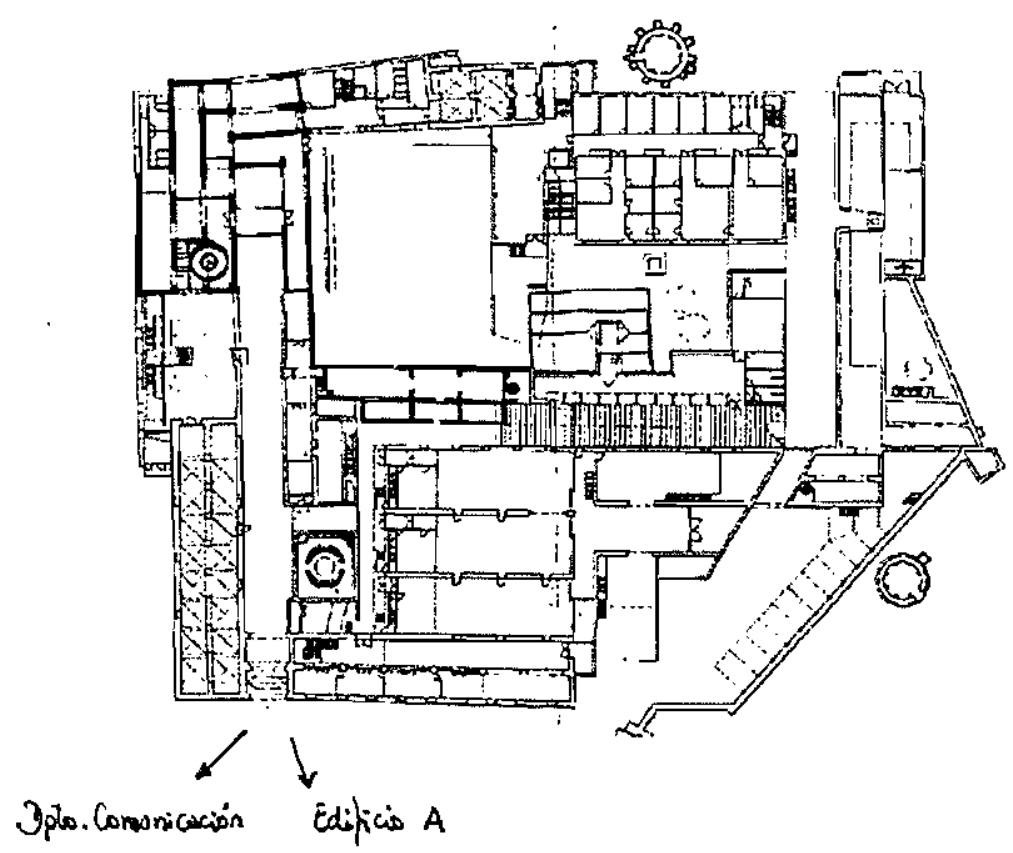

Plano de ubicación de áreas de servicio internas 


\subsection{ESPECIFICACIONES DE SEÑALÉTICA}

La señalética del Centro de Interpretación del Instituto Andaluz del Patrimonio Histórico comenzará en el exterior del monasterio, justo al lado del cartel anunciador del IAPH, donde se situará un monolito que avise de la existencia de un centro de visitantes en el interior. Cruzando la Puerta del Río, el visitante encontrará una flecha que incluye las palabras "Centro de visitantes" y señala el camino hacia el Callejón del Aire:

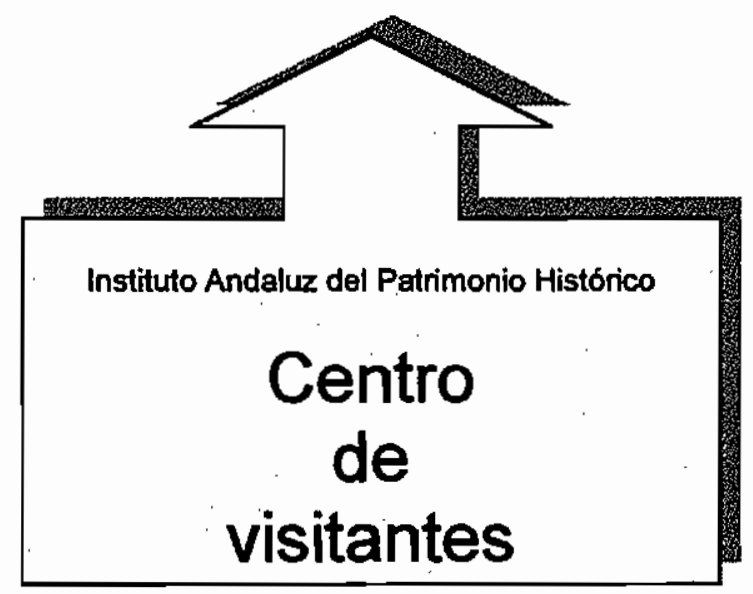

Como se observa será un cartel de fondo amarillo con letras negras NewsGothic (el tipo de letra, como se especificó en el apartado 3.5.1. que corresponde al Instituto) y tamaño $\mathrm{I}, 5 \times \mathrm{l} \mathrm{m}$.

La siguiente señal de orientación se halla enfrente de la puerta de entrada al Callejón del Aire, que servirá de aviso a los visitantes que vengan por la derecha (puerta del IAPH) o por la izquierda (desde el Monasterio/CAAC). Para estos últimos, se situarán tres flechas previas: una a la salida de la visita al Monasterio, otra a mitad de recorrido y una tercera en la esquina con el edificio $B$. 


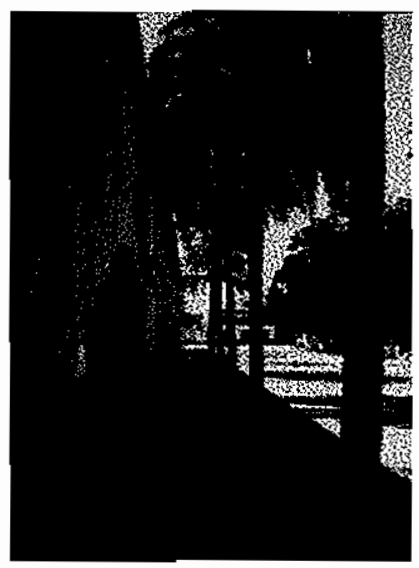

La última flecha anunciadora antes de entrar en el Centro de Interpretación se colocará en la puerta de entrada, al fondo del Callejón del Aire, bien visible desde el inicio de éste.

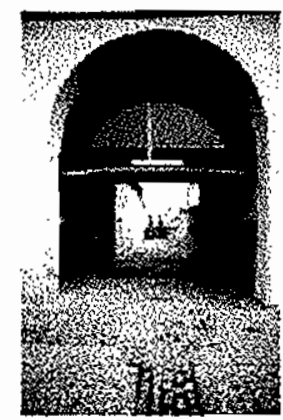

Una vez dentro del hall, el visitante se encuentra dos grandes carteles: uno anuncia el Centro de Interpretación (el objeto $n^{\circ} 0$ del recorrido, según se ha especificado en el apartado 3.5.1.), otro, la zona de exposiciones temporales. Este último será variable, del tipo: 


\section{El Hipnos de Almedinilla: la última intervención del IAPH}

Finalmente, en relación al recorrido principal, una vez se salga de la tienda habrá una señal en forma de flecha que guíe al público hacia la cafetería (un cartel anunciará su existencia) o hacia la salida de la visita (cartel de salida).

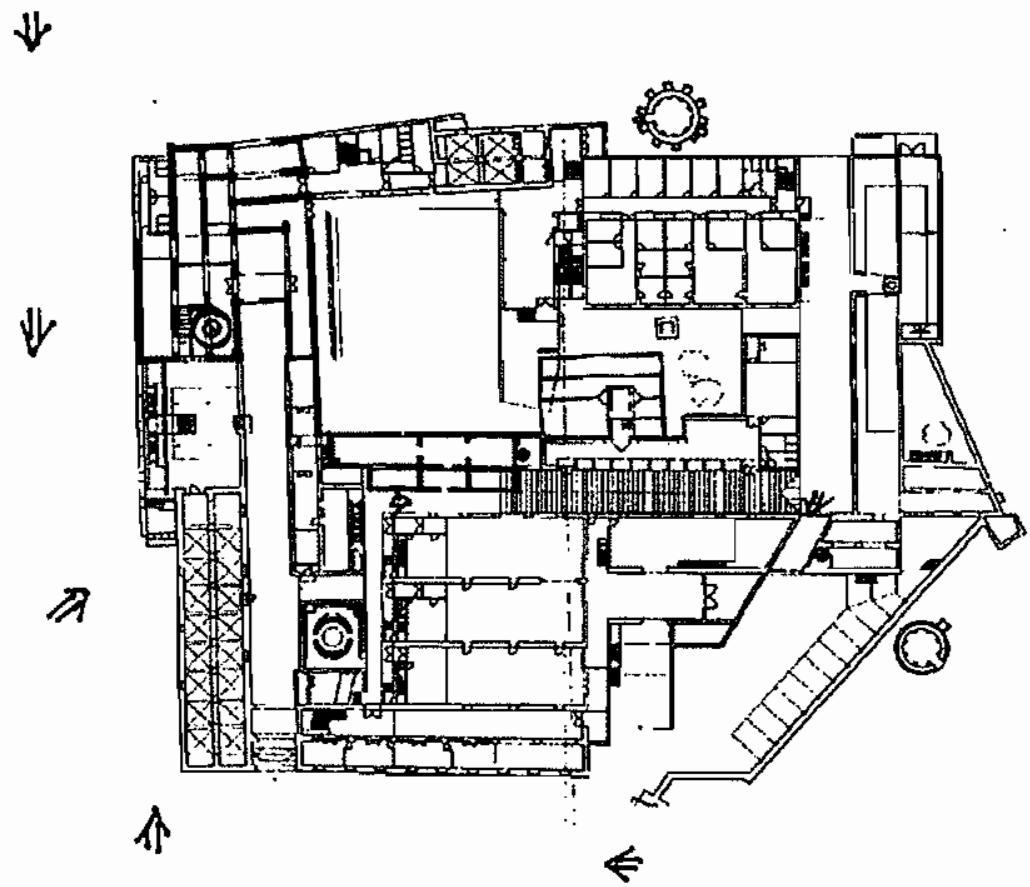

Plano de ubicación de la señalética descrita 


\section{CONTENIDO}




\begin{abstract}
Por lamlo, podemos iniciar la presentación de patrimonio entendido como sistema interrelacionado, que atienda las demandas del lugar, genere y fomente actividades patrimoniales y procure la participación. cooperación y cohesion social
\end{abstract}

(FERNÁNDEZ-BACA, 1999)

"Ha sido frecuente -escribe Román Fernández-Baca (1999) - estudiar y trabajar sobre los Bienes Culturales de espaldas a su contexto social. De ahí que desde hace algunos años exista una tendencia denominada Difusión social, como instrumento de conexión de cualquier actividad con el usuario y como último eslabón de toda acción cultural (...) Esta actividad ha sido especialmente necesaria y relevante sobre objetos inmersos en un determinado lugar (de dificil expresión, como por ejemplo los bienes arqueológicos), y que han requerido un esfuerzo complementario, a través de diversas técnicas, para transferirlo convenientemente. Esta implementación entre Bienes y su conexión con el ciudadano que tiende también, a realizarse hoy, a través de dinámicas diversas, como son los centros de interpretación o los circuitos en ámbitos territoriales determinados (y de gran utilidad para el gran público y su comprensión del hecho patrimonial), deben partir de una expresión basada en la interpretación culta, para transferirlo como producto cultural y no como es frecuente, por desconocedores de los fundamentos patrimoniales, como producto banalizado o folclórico y que atenta directamente contra el legado cultural"

Pero los lugares son colecciones de símbolos, y expresan mensajes a través de códigos. De ahí que su transmisión, su codificación-descodificación sea en muchos casos un proceso de torre de Babel donde el mensaje se diluye y se pierde. El contenido desaparece.

En nuestro caso, el Centro de Interpretación del IAPH tiene la obligación de poner al descubierto los atributos de funcionalidad y comunicatividad de la institución, sus valores denotativos y connotativos. Desde una perspectiva serniótica, vamos a entender que nuestro objeto patrimonial, el Instituto Andaluz del Patrimonio Histórico, tiene unas marcas interpretativas propias y distintivas, que transfieren el significado único, la separada identidad.

El mensaje del centro de interpretación coincide, pues, con el propio objeto de interpretación: el IAPH, su existencia, su valor y su significado. A este mensaje se supeditan todas las actuaciones y contenidos que se van a definir en este proyecto, todas los medios expositivos que ocuparán el futuro centro. Esto no significa, en efecto, que el centro de interpretación vaya a sustituir o intente sustituir al objeto de su explicación, sino que lo tendrá en todo momento presente, para poder transmitir su esencia con eficacia al público visitante. 
El contenido del centro de interpretación que proyectamos se aleja indudablemente del contenido de un museo tradicional e incluso de otros centros de interpretación, por su evidente carácter no objetual, puramente conceptual. El Instituto Andaluz del Patrimonio Histórico, sus objetivos y misiones, acciones y resultados son, pues, el principio y fin de este centro de visitantes, la colección que queremos dar a conocer.

A continuación, un recorrido por la institución nos da una idea de ella más completa' Comenzamos por el marco jurídico en el que se inscribe la creación y pervivencia del Instituto Andaluz del Patrimonio Histórico.

Según el Decreto 259/94 de 13 de Septiembre, modificado por el Decreto 333 /96 de 9 de Julio, de Estructura Orgánica Básica de la Consejeria de Cultura, a ésta le corresponde la preparación y ejecución de la política del Gobiemo en relación con, entre otras, la siguiente competencia de la Comunidad Autónoma de Andalucía:

La promoción y fomento de la cultura en manifestaciones y expresiones tales como patrimonio histórico, artistico, momumental, arqueológico, etnológico, bibliográfico y documental; archivos, bibliotecas y museos; investigacionn, fomento y divulgación de las artes plásticas del teatro, la misica, la danza, el folclore, flamenco y la cinematografia; apoyo y fomento de la lectura; las fundaciones y las asociaciones de carácter cultural y artístico; asociaciones y federaciones.

A la Dirección General de Bienes Culturales le corresponde con carácter general, la tutela, el acrecentamiento y la puesta en valor del Patrimonio Histórico de Andalucía, ejerciendo las funciones de protección, conservación, restauración, investigación y difusión a través de su administración territorial, por lo que desempeñará las siguientes funciones particulares:

1.- El conocimiento y la protección de los bienes del Patrimonio Histórico Andaluz mediante los instrumentos juridico-administrativos existentes. De manera especial, a través de la formación y conservación del Catálogo General del Patrimonio Histórico Andaluz y la tramitación de las declaraciones de Bienes de Interés Cultural y de Zonas de Servidumbre Arqueológica, asi como mediante la colaboración con la Administración del Estado en la formación del Inventario General de Bienes muebles, el Censo de los bienes integrantes del Patrimonio Documental y el Catálogo colectivo de los bienes integrantes del Patrimonio Bibliográfico.

2.- La adopcion de todas las medidas necesarias para hacer efectivo el deber de conservación, mantenimiento y custodia que corresponde a los propietarios, titulares de derechos o simples poseedores de bienes integrantes del Patrimonio Histórico Andaluz.

3.- Intervenir activamente en la formación, modificación, revisión y aprobación del planeamiento urbanistico y de los programas, proyectos y

'Para la elaboración de gran parte de este epigrafe se ha utilizado información de la página web
del Instituto Andaluz del Patrimonio Histórico: www. iaph.junta-andalucia.es (noviembre 2000) 
planes de todo tipo que pnedan incidir en el Patrimonio Histórico, mediante los mecamismos establecidos para cada caso.

4. - La protección y conservacion del Patrimonio Arqueológico y Emográfico.

5.- La conservación y restanración del Patrimonio Histórico Andaluz mediante los mecanismos que permitan garantizar la adecuacion de las obras $e$ intervenciones a los criterios y normas aplicables en esta materia asi como la sistematización de los resultados obtenidos $y$, en su caso, la supervisión de los proyectos de obras de la Consejeria. Y también a traves del análisis. estudio, desarrollo y difusion de las distintas teorias, métodos y técnicas de

, restauración que aseguren la permanencia del Patrimomio Histórico.

6.- La programación y coordinación del planeamiento urbanístico de protección en materia de Patrimonio Histórico, la emisión de los informes legalmente preceptivos y el seguimiento de la ejectición del referido planeamiento.

7.- La protección y conservación del Patrimonio Documental y Bibliográfico.

8.- La conservación restauración de los Bienes Culturales de Andalucia mediante el diagnóstico de su estado, la programación de las intervenciones, la propuesta de encargos de proyectos y su posterior visado conceptual, asi como el seguimiento e inspección técnica de las obras y restauraciones y el análisis y sistematización de los resultados obtenidos $y$, en su caso, la supervisión de proyectos de obras de la Consejeria.. Y tambien a través del análisis, estudio, desarrollo y difusión de las distintas teorias, métodos y técnicas de restantración que aseguren la permanencia del Patrimonio Histórico.

9.- El fomento y la investigación sobre el Patrimonio Histórico y su régimen de autorizaciones, asi como la difusion y puesta en valor del mismo.

Finalmente, el Instituto Andaluz del Patrimonio Histórico, como órgano especializado, dependiente de la Consejería de Cultura a través de la Dirección General de Bienes Culturales, realiza las siguientes funciones:

a. El desarrollo de las lineas generales del Plan Director, instrumento que define la actuación global y de largo alcance del Instituto.

b. La realización de actuaciones en materia de investigacion, enmarcadas dentro de las lineas generales de las actividades cientificas y de desarrollo tecnológico que establezca el Plan Andaluz de Investigación.

c. El análisis, estudio, desarrollo y difusión de teorias, métodos y técnicas aplicadas a la tutela del Patrimonio Histórico y de sus Instituciones. En concreto, a su investigación, protección, conservacion, restauracion y difusion. 
d. La realización de programas, planes, informes, diagnosis, proyectos y actuaciones concretas en el ambito de los hienes culturales y de las instituciones del patrimonio histórico.

e. La integración coordinación y sistematización de la información en el patrimonio historico y sus instituciones, con la finalidad de contribuir al estudio y conocimiento de los Bienes Culturales de Andalucia y satisfacer las necesidades de información de la administración, los investigadores y la sociedad en general.

f. El establecimiemto de planes de formacion de especialistas en los distintos campos del patrimonio histórico, promoviendo y organizando actividades formativas y fomentando la colaboración con instituciones privadas y organismos publicos, especialmente con el Instituto Andaluz para la Administración Püblica y las diferentes Universidades Andaluzas.

g. La asistencia técnica y la prestación de servicios contenidos en el Catálogo del Instituto Andaluz del Patrimonio Histórico, donde se recogerán las actividades o servicios que se ofrecen a la sociedad.

h. La acreditación de especialistas en materia de patrimonio histórico en los casos que se requiera.

i. La propuesta de formalizacion de convenios y la cooperación con otras Administraciones Publicas y organismos priblicos y privados necesarios para el desarrollo de sus funciones, tanto en el ambito nacional como en el imternacional.

j. Cuantas otras funciones le sean atribuidas por la Consejeria de Culitura.

Desde su creación mediante el Decreto 107/89, de 16 de Mayo (BOJA número 46, de 13 de Junio, corrección de errores en BOJA número 48, de 20 de Junio), el Instituto Andaluz del Patrimonio Histórico es una institución científica de la Junta de Andalucia adscrita a la Consejería de Cultura que tiene como objetivos el conocimiento, conservación y difusión del Patrimonio Histórico Andaluz mediante el estudio científico, documentación y la investigación y desarrollo de ciencias y técnicas aplicadas. Al mismo tiempo, lleva a cabo la formación de profesionales, mediante colaboraciones con instituciones privadas y organismos públicos. El IAPH se configura como institución $\mathrm{I}+\mathrm{D}$, por lo que pone a disposición diversos servicios especializados, descritos en el Catálogo de Servicios.

Además, y partiendo de la idea de que el patrimonio es una unidad de acción, donde confluyen diversas disciplinas con el fin de perpetuar la memoria para el futuro, el Instituto se proyecta en una doble vertiente formativa: la de mantener una permanente actualización del pensamiento patrimonial integrando otras políticas y la de ser nexo activo entre los agentes profesionales e instituciones del Patrimonio Histórico y la comunidad Andaluza. Con ello se pretende abrir nuevas vías de avance y renovación 
de los conceptos valorativos de los bienes culturales, y buscar una mayor rentabilidad e implicación de la actividad social en los recursos patrimoniales.

En este sentido se pronunciaba el Programa Especial para el Instituto Andaluz del Patrimonio Histórico del I Plan General de Bienes Culturales (pp.89-90):

Este órgano se plamea como ma institnción especializada de meva creación, con la máxima cualificación en la asistencia cientifica y técnica en todas las vertientes del amplio campo de la tmtela del Patrimonio Histórico (...) El Institnto Andalnz del Patrimonio Histórico serviria, justamente, de intermediario entre los distintos organismos e instimciones puiblicas y privadas, al actuar como centro planificador, supervisar las investigaciones en curso, ser receptor de las mismas (...) De esta forma seria una institución cientifica más, pero dedicada especificamente al Patrimonio Histórico en todas sus vertientes (...)

Posteriormente, en 1984, el Informe sobre el concepro, funciones y servicios. Función social y propuesta de planificación del Instituto Andaluz del Patrimonio Histórico para la $V$ Legislatura (1994) consideraba al IAPH heredero de los conceptos más actuales en relación al Patrimonio Histórico:

- Implementación disciplinar

- Búsqueda de un lenguaje patrimonial

- Entendimiento dual entre conservación y desarrollo

- Perfeccionamento continuo y especialización en el estudio

- Apertura en la investigación más dificultosa o sin experiencia

Pero, profundamente, el Instituto Andaluz del Patrimonio Histórico tiene la misión de acercar el Patrimonio a la sociedad, para cumplir con el deber de devolverle el legado a la sociedad y, a través del conocimiento y la información, conseguir la permanencia del legado generacional. De ahi, su intensa función social, también ampliamente reconocida en el citado informe, y que se define del siguiente modo:

- La introducción conceptual del IAPH ha incidido especialmente en que toda actividad debe llevar inherente su finalidad social (...)

- Eul materia de Documentación e Información del PH, permitirá un avance contimo, en el acercamiento del Patrimonio a la sociedad.

- En materia de Intervención, los proyectos interdisciplinares pueden abrir las frouteras profesionales eln un mejor hacer ell el $\mathrm{PH}$ (...)

- En Formación es una actividad que repercute directamente en la mejora de la actividad patrimonial (...)

- Y la difusión del hacer del Instituto (...), implicando el contraste de opinión, los prominciamientos iniciales, la participación en la formación de criterios y proyectos comunes.

\footnotetext{
${ }^{2}$ Palabras pronunciadas por el Excmo. Consejero de Cultura de la Junta de Andalucia ante el Parlamento
} 
- Todas estas misiones se entienden en cooperacion con otras Institnciones publicas o privadas, nacionales o extramjeras, asi como con las Universidades Andaluzas o profesionales, generando la participacion de colectivos diversos en la acción Patrimonial y vinculando actividades cientifico-técnicas a la realidad social del Paurimonio

El Instituto Andaluz del Patrimonio Histórico se vertebra según eI siguiente esquema, que se inicia en la figura de un Director que dirigirá y coordinará la actuación de los siguientes órganos:

- Departamento de Administración y Régimen Interior.

- Centro de Documentación del Patrimonio Histórico.

- Centro de Intervención del Patrimonio Histórico.

- Centro de Formación del Patrimonio Histórico.

- Centro de Arqueología Subacuática.

Comenzaremos recordando las funciones del DIRECTOR DEL IAPH, que se concretan en la ostentación de la representación de la Consejería en el IAPH y de los órganos colegiados del Instituto que preside. Corresponden al Director las siguientes atribuciones:

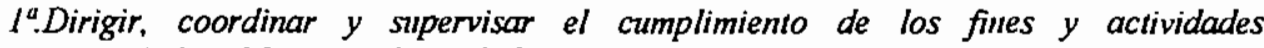
encomendadas al Instituto dictando las instrucciones precisas para su funcionamiento.

2.Elaborar o formular y elevar los planes del IAPH a la Consejería de Cultura.

3.Dirigir, controlar y evaluar los Planes.

f.Elaborar la propuesta presupnestaria sobre las necesidades del Instituto para cada ejercicio económico.

$5^{a}$. Elaborar la Memoria Amıal sobre la gestion del Instituto.

$6^{a}$.Impulsar los acuerdos de cooperación cientifica y técnica con instituciones y organismos priblicos y privados.

$7^{a}$.Visar las certificaciones y documentos oficiales del Instituto.

$8^{a}$.Presidir la Comisión de Coordinación del IAPH.

$9^{a}$.Aprobar y controlar los programas y subprogramas sectoriales del IAPH, previo informe de la Comisión de Coordinación.

10.Aprobar los proyectos en los que intervienen más de un Centro. 
Además, el director del IAPH ostenta la presidencia de la COMISIÓN TÉCNICA, órgano consultivo del Instituto, que desartolla sus actividades en Pleno o mediante la constitución de Ponencias, colegiadas o unipersonales, en relación a temas específicos. Está compuesto por:

a. Presidente/a: El Director/a del Instituto.

b. Ocho vocales de libre designación nombrados por el Consejero/a de Cultura por un periodo de tres años, de entre los expertos de reconocido prestigio en el campo del patrimonio histórico.

c. Relación de personas que componen la Comisión Técnica.

El DEPARTAMENTO DE ADMINISTRACIÓN del Instituto Andaluz del Patrimonio Histórico, como órgano de gestión, desarrolla su actividad a través de tres grandes áreas de trabajo:

$\mathrm{I}^{\mathrm{a}}$ - El Área de Gestión Financiera, en cuyo ámbito se elabora el presupuesto, se articulan los expedientes de contratación administrativa y se instrumentan los mecanismos de control del gasto.

$2^{a}$.- El Área de Cooperación y Colaboración, encargada de gestionar y fomentar los convenios y acuerdos con otras instituciones publicas o privadas, para el desarrollo de sus comunes intereses.

$3^{a}$ - El Área de Personal y Régimen Interior, donde se lleva a cabo la gestión de recursos humanos cubriendo, las necesidades tanto del trabajador como del Instituto y, optimizando el uso de los bienes e instalaciones donde se desarrolla el trabajo.

Y tiene atribuidas las siguientes funciones:

a. La elaboración y gestión del presupuesto, el control de ingresos y gastos y la contratación administrativa dentro del ámbito de sus competencias.

b. La gestión de los astmtos relacionados con el personal y régimen interno.

c. El fomento de la cooperación y colaboración con otras administraciones priblicas e instituciones priblicas o privadas.

d. La elaboración y actualización del Registro de Profesionales en materia de patrimonio histórico, asi como facilitar la acreditación de especialistas en los casos que se requiera.

e. Cualquier otra función que en materia de administración y régimen interior le sea atribuida por el/la Director/a. 
En cuanto al CENTRO DE DOCUMENTACIÓN, con nivel orgánico de Servicio, hay que señalar las siguientes funciones aplicadas al patrimonio histórico de Andalucia y a sus Instituciones:

a. La formulacionn y desarrollo de programas de investigación aplicados a la documemación e información del patrimonio historico andallz, asi como la articulación de la transferencia de los resultados de la investigación

b. La realización de los planes de información del patrimonio histórico relativos a los bienes, a las instituciomes y a las fuentes de informacion del patrimouio histórico andaluz.

c. La asistencia técnica en los procesos de documentación e información del patrimonio histórico andaluz y stus instituciones.

d. El desarrollo de la prestación de servicios y productos de información a través del archivo, el banco de datos y la biblioteca, incorporados a una red de información sobre patrimonio histórico de Andalucia y definidos en el catálogo.

e. El intercambio técnico y cientifico con otros centros de documentación en el ámbito del patrimonio histórico.

El Centro de Documentación se encarga de desarrollar el Sistema de Información del Patrimonio Histórico de Andalucía (SIPHA), mediante la integración y coordinación de la Red de Información de las diferentes instituciones y organismos que contienen documentación e información sobre el Patrimonio Histórico de nuestra Región. Para el desarrollo de sus objetivos ha emprendido diversas líneas de actuación consistentes en:

a) Desarrollo de la Información sobre PH a través de la formulación y puesta en marcha del sistema básico de Patrimonio Histórico, asi como de diversos sistemas temáticos sectoriales de patrimonio histórico, de sus fuentes y de las instituciones que lo albergan o la gestionan. Como resullado se han elaborado unos productos de información, accesibles a través de los servicios de información.

b) Investigación y Desarrollo del sistema informático y de las técnicas gráficas.

c) Transmisión de sus resultados a través de determinados servicios de información. con el objetivo de contribuir a la mejora de la información sobre patrimonio histórico en Andalucia. 
El Centro de Documentación se articula para el desarrollo de estas funciones en tres Departamentos, con sus recursos humanos correspondientes.

- El Departamento de Desarrollo de la Información

El departamento de Desarrollo de la Información se encarga del diseño y desarrollo del Sistema Básico del Patrimonio Histórico y de los sistemas de información temáticos, concebidos como el núcleo central del SIPHA, e integrados por diferentes bases de datos (productos de información) con una estructura modular en donde reside toda la información seleccionada sobre los Bienes integrantes del Patrimonio Histórico, y que contempla la incorporación de información referente al territorio en el que se ubican.

Asimismo se ocupa de la puesta en marcha de diferentes sistemas de información institucionales específicos para las diversas áreas de tutela del Patrimonio Histórico. Desarrolla una amplia labor de normalización, tanto en la configuración de la estructura del SIPHA y diseño de las bases de datos como en el establecimiento de criterios para la selección de la información y normalización terminológica.

Los recursos humanos de este departamento incluyen técnicos especialistas en patrimonio histórico y documentación: antropólogos, arqueólogos, arquitectos, historiadores del arte y documentalistas.

- El Departamento de Técnicas Gráficas e Informáticas

El Departamento contempla la incorporación de las nuevas tecnologías, mediante técnicas de documentación gráfica aplicadas al Patrimonio y el desarrollo de los sistemas informáticos como soporte del Sistema de Información del Patrimonio Histórico de Andalucía (SIPHA). Se estructura en dos áreas:

-El Área de Técnicas Gráficas, se ocupa de aplicar estas nuevas tecnologías a la documentación del Patrimonio Histórico, mediante la digitalización y tratamiento adecuado de las mismas en los diferentes soportes en que pueden presentarse para su asociación a las diversas bases de datos establecidas en el Centro de Documentación. Su objetivo es crear un Banco de Imágenes del Patrimonio Histórico de Andalucía y, por otro lado, la elaboración de productos digitales en CD-ROM que sean atractivos en su consulta y que sean válidos para la divulgación del Patrimonio Histórico Andaluz.

-El Área de Técnicas Informáticas, se encarga del diseño y configuración de la estructura informática del SIPHA. Actualmente se ocupa de la elaboración de un primer sistema informático integrado, soporte del Sistema Básico del Patrimonio Histórico, que ha partido de las aplicaciones sectoriales existentes, así como un Registro General de Imágenes, que se encuentra en fase de alimentación. 
Asimismo desde esta área se prevé el desarrollo de la Red de Información de Patrimonio Histórico Andaluz que permitirá la conexión entre las redes locales de las diferentes instituciones del Patrimonio, creando un sistema que sea capaz de comunicarse con otros sistemas, transmitiendo y compartiendo información entre si.

La Red de Información del Patrimonio Histórico de Andalucia (RIPHA) integra a instituciones y organismos que contienen documentación e información sobre el patrimonio histórico en Andalucia.

- El Departamento de Información

Su objetivo principal es poner la información del Patrimonio al servicio de la tutela, de la investigación, de los profesionales, así como del público interesado en el mismo, por diferentes medios; asi como la formación de un fondo bibliográfico y documental sobre Patrimonio Histórico. Para ello, se estructura en tres áreas:

-Biblioteca, cuyas labores están encaminadas a la selección y adquisición del fondo bibliográfico y documental mediante compra, donación e intercambio; a la catalogación de los fondos que produce el catálogo del fondo bibliográfico y la base de datos gráfica, a la elaboración de otros productos como boletines de adquisiciones o boletines de novedades, y a la prestación de servicios actualmente disponibles a través de la consulta en sala y del préstamo.

-Área de Información, especializada en la atención y comunicación con los usuarios. En la actualidad está desarrollando de forma prioritaria el servicio de demandas puntuales de información que sobre Patrimonio Histórico se reciben, asi como otros de carácter intemo tales como los servicios de dosieres de prensa y de boletines oficiales.

-Área de Internet, que tiene una doble finalidad genérica, por un lado constituyéndose en proveedora de información a través de la planificación, creación y desarrollo del Servidor Web del IAPH, y por otro lado en usuario de los recursos de información disponibles en la red.

El CENTRO DE INTERVENCIÓN del Patrimonio Histórico, el segundo núcleo básico del IAPH junto al Centro de Documentación ya descrito, ejerce las siguientes funciones aplicadas al patrimonio histórico de Andalucía y a sus instituciones:

a. La formulación y desarrollo de programas de investigación aplicada a la conservación y restauración del patrimonio histórico andaluz.

b. La formulación y desarrollo de estudios, metodologias y normativa en materia de conservación y restauración, asi como la experimentación y puesta apumto de técnicas analiticas, de ensayos y de tratamientos para el 
diagnóstico, la conservacion preventiva y la intervencion en el patrimonio historico.

c. La asistencia técnica y cientifica mediante la prestacion de los servicios definidos en el correspondiente catálogo.

d. La realización de acuerdo con sus competencias de intervenciones concretas en el patrimonio historico andaluz, conforme con los criterios de urgencia, valor y calidad patrimonial, especifidad metodológica, particular complejidad, exigencias de investigación ofines didácticos.

e. El intercambio técnico y cientifico con otros centros de investigacion aplicada, especializados en conservación y restanración del patrimonio histórico.

El Centro de Intervención ejerce sus funciones en los siguientes campos relativos al patrimonio histórico andaluz y sus instituciones:

a) Investigación de teorias, métodos, proyectos y actuaciones

b) Análisis y experimentación de materiales y técnicas mediante laboratorios de análisis y aplicación

c) Tratamiento de materiales y técnicas de conservación en talleres especializados

Desde su efectiva puesta en marcha (finales de 1990) con la incorporación de los primeros profesionales, se han venido consolidando varias líneas de trabajo:

a) Formulación del marco conceptual y metodológico de base para la intervención en el patrimonio histórico

El Centro de Imtervención ha creado, con éxito, un método de trabajo moderno construido a partir de la concurrencia de principios cientificos, interdisciplinares y sociales, en consonancia con las corrientes de pensamiento y actuación vigentes en instituciones culturales europeas de caracteristicas similares al I.A.P.H. La ciencia de la intervención sobre los bienes culturales es una disciplina con principios teóricos y metodológicos claramente establecidos. Su práctica exige que las decisiones estén precedidas y basadas en la identificación de la materialidad fisica del bien, y en la determinación de sus valores estéticos, históricos y documentales. Las decisiones se fundamentan en evidencias cientificas y conocimientos firmes $y$ jamás en suposiciones.

Pero además, para el Centro, la acción sobre el bien se enuncia desde unas bases conceptuales en consonancia con el pensamiento y la filosofia artistica del momento pero con la cautela del rigor cientifico. Este rigor se traduce en complejidad de acción y ésta exige la incorporación al método de estudios, segin los casos, de 
estructura material, de compatibilidad de productos y materiales de restanracion, de ambiente, elc.

El comllacto diario y la colaboracion entre el cientifico, el historiador y el restanrador son la clave del exito del método de trabajo que se formula desde el Centro.

b) Creación de las infraestruchuras iecmicas y cientificas necesarias para el desarrollo de proyectos de intervencion en bienes del patrimonio historico andalaz

Se han puesto efectivamemte en marcha los Talleres de Tejidos, Escultura. Pintura. Parrimonio Documental y Gráfico, Material Arqueologico e Inmmebles, asi como los Laboratorios de Folografia y Radiografia, Geologia y Ensayo de Materiales, Quimica, Biologia y Paleobiologia.

c) Formulación y posterior ejecución de proyectos de investigación básica y aplicada

Se han formulado los primeros proyectos y programas de investigación $e$ intervención, siempre con carácter experimental e interdisciplinar. En este campo, se ha optado por la figura del Proyecto Piloto por entenderlo el instrumento más adecuado para la experimemación en los campos teóricos, metodológicos y prácticos, apto, por su flexibilidad para su ejemplificación, normalizando sus conclusiones y extrapolando sus resultados de cara a las actuaciones ordinarias sobre el patrimonio histórico andaluz.

En materia de investigación se trabaja pora potenciación de la capacidad y investigadora y recursos cientificos de forma especial en materia de ciencias $y$ técnicas aplicadas a la conservación del patrimonio histórico, a través del programas de investigación Ciencias y Tecnologia del Patrimonio Histórico. Asimismo el Centro procura fomentar la transferencia de resullados de la investigación hacia las Instituciones del Pärimonio Histórico y los departamentos de la administración de la Comunidad Autónoma con responsabilidad en la tutela del Patrimonio Histórico, y trabaja en la formulación del proyecto de constitución del I.A.P.H. como Centro Público de Investigación en el marco del II PAI.

d) Prestación de servicios técnicos y cientificos en materia de conservación $y$ restauración de bienes culturales

e) Desarrollo de programas de conservación preventiva del patrimonio histórico andaluz

Desde un punto de vista orgánico, el Centro se vertebra en tres departamentos:

- El Departamento de Investigación

La labor fundamental del departamento es la coordinación de las estrategias de investigación y desarrollo que ejecuta el Centro de Intervención. Además es el encargado de coordinar en el ámbito del las diversas acciones correspondientes al 
subprograma de patrimonio histórico definido en el II Plan Andaluz de Investigación, asi como de fomentar la cooperación con los distintos grupos de I+Dt que trabajan en este campo.

El departamento se articula a través de la unidad de estudios y metodologia y la unidad de diagnosis y proyectos.

Comesponde a la unidad de estudios y metodología las siguientes funciones:

a) El estudio genérico de las ciencias de la conservación, restauración y rehabilitacion de los bienes culturales, asi como de las Institnciones del Patrimonio Histórico. La unidad, estudia, propone y desarrolla la teoria que sustenta las actuaciones concretas, definiendo criterios de intervención coherentes con la formulación teórica determinada.

b) La formulacion de estudios y acciones concretas de intervención considerando las diferentes visiones o metodologias parciales $e$ incardinándolas en un proceso complejo pero implememado y organizado.

c) El estudio de otras experiencias nacionales e intentacionales que hayan formulado una metodologia de interés, y/o lleven a cabo proyectos de intervención cuyo conocimiento sea de interés para el LAPH.

d) La formulación de las investigaciones históricas necesarias para la intervención en el patrimonio histórico, entendida ésta como un proceso histórico-critico con fases sucesivas, en $5 \mathrm{su}$ caso, de investigación filológica, restitución de la imagen $y / o$ de las formas, análisis iconográfico y valoración figurativa.

e) La ejecución de los proyectos de inspección, documentacion y análisis de los elementos formales, gráficos, geométricos, estructurales y constructivos aplicados a los programas de intenvención en el patrimonio histórico.

f) La coordinación de la participación del LAPH en el Plan Andaluz de Investigación.

g) La formulación de las investigaciones en materia de consenvación preventiva asi como la ejecución de las intervenciones en este área.

Corresponde a la unidad de diagnosis y proyectos las siguientes funciones:

a) La formulación y coordinación de los proyectos referidos a las instituciones del patrimonio histórico.

b) La formulación de los Proyectos Pilotos de Intenvención en el patrimonio, y de otras acciones tutelares encaminadas a profundizar en problemáticas complejas y significativas que puedan ser de utilidad al 
Provecto para un centro de interpretacion del lastituto Andaluz del Patrimonio Histórico

conjmuto de acciones que deben establecerse desde la administracion cultural.

- El Departamento de Análisis

El Departamento de Análisis desarrolla su trabajo para conseguir un mejor conocimiento de los Bienes Culturales, así como de las técnicas y productos de tratamiento, con el fin de acometer las intervenciones sobre los mismos en las mejores condiciones posibles.

Los objetivos del Departamento se centran fundamentalmente en los siguientes puntos:

a) Estudiar la materialidad de la obra, determinando los materiales que la constituyen, su técuica de ejecución, la procedencia de dichos materiales y la datación de la obra.

b) Determinar el estado de conservacion de la obra, viendo las transformaciones fisicas y quimicas que ha podido suffir, y cómo estas transformaciones pueden afectar a su contimidad en el tiempo.

c) Definir los factores de deterioro que afectan a las obras, tanto los intrinsecos (st propia estrictura material) como los extrinsecos (microclima, contaminación, agentes biológicos, condiciones de uso y exposición, etc.).

d) Evaluar el comportamiento de los productos y técnicas de tratamiento, tamto previamente a si aplicación, con la aynida de ensayos de laboratorio, como después de la misma, en forma de seguimiento periódico de las obras restauradas.

El Departamento se estructura en una serie de unidades, que tienen una manifestación física en forma de laboratorios: Química, Geología y Ensayos de Materiales, Biología, Paleobiología, Fotografia y Radiografia.

El Departamento participa en diversos proyectos de investigación, tanto sobre obras concretas como sobre metodologia general de análisis y ensayos, y tiene establecidos acuerdos de colaboración con distintos centros investigadores, tanto Departamentos universitarios como Institutos del Consejo Superior de Investigaciones Científicas, con objeto de fomentar la investigación aplicada a la conservación del Patrimonio Histórico.

\section{- El Departamento de Tratamiento}

Se trata de un área que desarrolla de forma orgánica las intervenciones en las diferentes tipologías del Patrimonio mueble y entiende la intervención desde un óptica amplia que parte del conocimiento del bien, de su contexto y de los condicionantes a los que está sometido, con objeto de establecer el origen y las causas de alteración que les afecta, definir el estado de conservación real, y en 
consecuencia, aplicar los tratamientos técnicos que requiere de acuerdo con los criterios de actuación adecuados con vistas a su conservación temporal.

De igual forma actúa en el campo de la conservación preventiva a partir de propuestas específicas que determinen las medidas más adecuadas para su correcta exposición, traslado, embalaje, mantenimiento, etc.

Para el desarrollo de estas actividades se ponen a punto métodos de estudios y conocimiento del bien y técnicas de tratamiento generales y específicas con objeto de establecer y aplicar la metodología concreta que requieran según su casuistica.

Los objetivos del Departamento son:

1. Efectuar estudios, intervenciones, informes técnicos y asesoramientos de aquellos bienes culturales que por su elevado interés histórico-artistico, particular complejidad técnica, de investigación o de tratamiento les sean encomendados.

2. Aplicación y desarrollo de la metodologia de estudios previos, diagnosis, y tratamiento especifica puesta a punto por este Departamento.

3. Desarrollo de mevas lineas de investigación, tecnologias de tratamiento, materiales y productos aplicados al conocimiento $e$ intervención de bienes muebles.

t. Elaboración de proyectos y dirección de intervenciones.

5. Potenciar la cooperación con otras entidades para el conocimiento e investigación de bienes culturales.

En la actualidad este Departamento se estructura en cinco Talleres diferentes que abarcan la intervención en las tipologias de bienes muebles más usuales de nuestra Comunidad Autónoma: Pintura, Escultura, Tejidos, Material Arqueológico, Patrimonio Documental y Gráfico e Inmuebles.

Se complementa con otras instalaciones comunes: recepción, almacén de obras de arte, cámara de climatización previa y almacén de materiales. Próximamente esta estructura se verá ampliada con una cámara de desinfección-desinsectación y una cámara de barnizado de bienes muebles.

En cada uno de estos cinco talleres, o unidades técnicas, se residencian las siguientes funciones:

a) Proposición de estudios preliminares a la intervención del bien cultural e interpretación de la documentación resultamte.

b) Elaboración del diagnóstico e informe técnico de la intervención (textual y gráfica) mediante fichas técnicas normalizadas que permiten el 
tratamiemo informático de los datos resnltantes derivados de los estudios previos y cle la propia actuacion.

c) Realización del estudio, asesoramiento, intervención o proyecto de investigacion. conservacion-restanración de bienes muebles.

Por otro lado, el programa de servicios para la intervención en el patrimonio histórico recoge y sistematiza el potencial de prestaciones técnicas y científicas que el Instituto Andaluz de Patrimonio Histórico ofrece en materia de conservación y restauración de bienes culturales. El programa, instrumentalizado a través del Catálogo de Servicios del I.A.P.H. pretende dar una respuesta unificada e integrada a la demanda de prestaciones de esta naturaleza que surgen tanto en la Dirección General de Bienes Culturales como en las Instituciones del Patrimonio Histórico dependientes de la Consejeria de Cultura.

Entre los servicios que se prestan se encuentran más de un centenar agrupados en las siguientes áreas: examen científico de bienes del $\mathrm{PH}$, métodos y técnicas de intervención y conservación preventiva, diagnósticos y proyectos, valoración y autentificación de obras de arte y prevención de riesgos en conservación e intervención.

Dejando aparte los núcleos fundamentales -Centro de Documentación y Centro de Intervención-, el CENTRO DE FORMACIÓN Y DIFUSIÓN del Patrimonio Histórico no deja de ser imprescindible.

El Area de Formación del Patrimonio Histórico ejerce las siguientes funciones aplicadas a la formación continuada del personal especializado en patrimonio histórico y sus instituciones y la difusión de las actividades del Instituto Andaluz del Patrimonio Histórico por medio de las siguientes funciones:

a. La formulación y desarrollo de programas de formación en el patrimonio histórico y stis Instimciones, mediante la organización de cursos y seminarios.

b. La propuesta de convocatoria de becas y ayudas para la formación personalizada en materias especializadas del patrimonio histórico, asi como la realización de las actividades de indole material o técnico que les sean encargadas en el procedimiento de concesion de las mismas.

c. La formulación y evaluación de programas de investigación aplicados a la difisión del patrimonio histórico y stis instituciones.

d. El intercambio de conocimientos, experiencias e información con otros centros, dentro del área de la formación. 
Aunque la formación no era ningún Programa del Plan General de Bienes Culturales 89-95, su necesidad era sentida como uno de los problemas estructurales del Patrimonio Histórico en Andalucia. Así lo expresaba indirectamente el Plan en la introducción del Consejero de Cultura:

La ausencia de un nimero adecuado de profesionales de alto nivel de especializacion en el campo de la tutela, conservación o restauracion de los bienes culturales

La mayoria de los Programas en que se organizaba el Plan General 89-95 contemplaban entre sus objetivos propuestas de formación y algunos remitían al Instituto Andaluz del Patrimonio Histórico como la institución idónea para impartir ésta.

No obstante, entre las funciones del "Programa Especial: IAPH", no se incluian claramente objetivos de formación, sino dentro de los genéricos de difusión. Esta característica se refleja posteriormente en el Decreto de creación del IAPH, en el que se contempla un Centro de Documentación, un Centro de Intervención, pero no uno de formación, actividad que se incluye en un Departamento de Formación y Difusión dentro del área administrativa.

Ello no ha impedido que en los últimos años se hayan iniciado desde el IAPH diversas modalidades de formación: masters con las Universidades de Sevilla y Granada, becas de formación en el IAPH y cursos de formación.

Pero quizá lo más importante es que durante ese tiempo el IAPH elaboró y puso en marcha un Programa de Formación, documento que, resumido y actualizado, está incluido dentro del Plan General de Bienes Culturales 96 -2000.

Por otro lado, el Área de Comunicación organiza jornadas de debate profesional y desarrolla la linea editorial de publicaciones del IAPH, mediante su Colección Cuademos y su Boletín PH. De igual modo es el responsable de la difusión de las actividades del propio Instituto. Este departamento también desarrolla exposiciones divulgativas de las actividades del Instituto y organiza visitas al Instituto.

En definitiva, las áreas de Formación y Comunicación son las principales herramientas del IAPH para extender su labor y hacerla llegar a la sociedad.

Finalmente, el CENTRO DE ARQUEOLOGIA SUBACUȦTICA cierra el esquema estructural del IAPH.

Una mención aparte merece este Centro de Arqueología Subacuática (C.A.S.) dependiente del Instituto Andaluz del Patrimonio Histórico (I.A.P.H.) y que tiene su sede en el Balneario de la Palma y el Real, en Cádiz, un edificio construido en 1.92426 y rehabilitado para este fin. Su campo de actuación se centra en la investigación 
documental, intervención, conservación y restauración del Patrimonio Arqueológico Sumergido existente en el territorio andaluz, a través de las siguientes lineas de actuación:

a. La formulacion y desarrollo de propnestas de investigacion e intercambio cientifico en el patrimonio arqueologico subacuático y en el marco del Plan de lnvestigación e Imovación Tecnologica de los Bienes Culturales.

b. La formulación. propnesta y desarrollo de programas de estudios. diaguosis y proyectos de protección. documentacion, conservación y formación para el Patrimonio Arqueológico Sinbacuático, de acnerdo con las lineas de trabajo de los restantes Centros del listituto Andaluz del Patrimonio Histórico.

c. El asesoramiento y la asistencia técnica y cientifica mediamte la prestación de los servicios especializados definidos en el correspondiente catálogo.

d. La realizacion de intervenciones concretas que resulten adecuadas en el ámbito del patrimonio arqueológico subactítico, con arreglo a los criterios de urgencia, valor y calidad patrimonial, especifidad metodológica, exigencia de investigación o fines didácticos, previstos en el Plan Amal y el Plan Director.

e. La protección del Patrimonio Arqueológico Subacuático andaluz en el marco de los recursos y programas establecidos por la Dirección General de Bienes Culturales.

Todas estas funciones se llevan a cabo por medio de tres departamentos:

- Departamento de Investigación y Documentación del Patrimonio Arqueológico Subacuático

- Departamento de Investigación e Intervención

- Departamento de Investigación y Actuaciones en Conservación y Restauración 


\section{PROGRAMA DE CONSERVACIÓN PREVENTIVA}




\subsection{DETERMINACIÓN DE NECESIDADES SEGÚN EL VOLUMEN Y NATURALEZA DE LOS BIENES}

La conservación preventiva engloba la aplicación concertada de medidas directas e indirectas que han sido definidas con precision" y estál ellcaminadas a prevenir las causas naturales y humanas del deterioro de las colecciones, a fill de aumentar su esperanza de vida y garantizar la difusion del mensaje que contienen

(GÄEL DE GICHEN)

El Centro de Interpretación del Instituto Andaluz del Patrimonio Histórico cuenta con un programa de conservación preventiva que se aplicará exclusivamente -por razones obvias- en la zona de exposiciones temporales cuando el carácter de lo expuesto asi lo determine. Concretamente, y dado que el programa de exposiciones temporales contempla especialmente la posibilidad de exponer sucesiva e ininterrumpidamente las obras que vayan siendo restauradas en los talleres del IAPH', será en estos casos cuando se aplique el programa de conservación preventiva en su totalidad (control de constantes ambientales, control de iluminación, control de manipulación y plan de seguridad). Siempre se decidirá atendiendo las recomendaciones de los restauradores responsables del tratamiento de la obra intervenida ${ }^{2}$. Adaptarse, entonces, a las caracteristicas de los bienes, implicar a todo el personal directo o indirecto y ser consciente de las disponibilidades reales de presupuesto serán tres premisas de la conservación preventiva en nuestras salas.

Consideramos que la sala prevista puede albergar tanto obras pequeñas como de mayor tamaño, lo que nos permite su versatilidad a la hora de exponer la mayor parte de los bienes que vayan siendo restaurados. En casos excepcionales -como podria ser la

\footnotetext{
${ }^{1}$ En los demás y menos frecuentes casos, dedicados a exposiciones temporales temáticas -no sobre intervenciones recientes (ver apartado 3.5.2.)- se tendrá una consideración climática y de seguridad similar a la del resto del centro de interpretación (zona expositiva y talleres didácticos), es decir, la estipulada con carácter general por el área de Mantenimiento y de Seguridad para el resto de zonas de la institución que no requieren tratamiento especial.

${ }^{2} \mathrm{Ni}$ que decir tiene que, cuando la exposición de intervención reciente además de ser temporal sea itinerante, el responsable de conservación preventiva del Centro de Interpretación del IAPH se encargará en todo momento de velar por el correcto cumplimiento de las recomendaciones de conservación preventiva propuestas por el área de tratamiento (talleres) del IAPH.
} 
exposición de ias alfombras nazaries o dei Giraidiilio restaurado- habria que buscar un mayor y más lucido espacio ${ }^{3}$. Pero esto son, ya decimos, excepciones.

Por otro lado, dado el escaso número de bienes que van a ser expuestos en cada muestra -se estima que de una a tres obras podrán ser exhibidas al mismo tiempo- la aplicación de normas y recomendaciones de conservación preventiva se verá agilizada y favorecida, al no tener que buscar el punto de equilibrio entre las necesidades de muchas y muy diferentes obras. El control y la conservación preventiva serán variados en cuanto a necesidades de los materiales expuestos, ya que -debido a la multiplicidad de taileres en ei IAPH- nos encontraremos con bienes textiies, pictóricos, escuitóricos, documentales,' arqueológicos o metálicos.

A continuación estabiecemos unos parámetros de carácter general, que variarán en función del tipo de material expuesto, el tamaño y otras necesidades puntuales de la obra, que serán convenientemente apuntadas por los responsables de lntervención del IAPH y que se adaptarán en todo caso a las condiciones climáticas que hayan sido establecidas en el taller de intervención.

\footnotetext{
${ }^{3}$ Puntualmente, los propios talleres de restauración (especialmente, por sus dimensiones, los de pintura, textil y escultura) podrian servir de espacio expositivo, de área de exposiciones especiales.
} 


\subsection{CONTROL DE LAS CONSTANTES AMBIENTALES}

El control del medio ambiente (temperatura y humedad relativa, fundamentalmente) conlleva el conocimiento previo de los materiales y de sus reacciones ante las variables. De este modo, y sin establecer medidas fijas y estándares sino respondiendo a las necesidades y condiciones particulares y fluctuantes, se organizarán los parámetros climáticos.

En cualquier caso, se evitarán fluctuaciones de la temperatura y la humedad relativa controlando (GARCIA DE LA TORRE, 2000):

. el número de visitantes, que alteran con su presencia los valores de temperatura y de humedad relativa ${ }^{4}$

- el tipo y el encendido de luces, que pueden aumentar considerablemente la temperatura

- la limpieza de suelos, que hace subir el parámetro de la humedad relativa

. los posibles cambios bruscos de los parámetros (a causa de las variaciones entre el día y la noche o los cambios de estaciones)

. posibles filtraciones por agua

Asimismo, se intentará -en la medida de lo posible- compaginar las necesidades de conservación con el confort de los visitantes.

Con objeto de que la obra no sufra modificaciones climáticas que repercutan negativamente en su estado fisico, la sala de exposiciones temporales deberá presentar unos parámetros de temperatura (la sala cuenta con aire acondicionado) y humedad relativa (controlada con humidificadores/deshumidificadores y un hidrostato) similares a los que presentaba el taller de restauración ${ }^{5}$. Con los mismos fines, el traslado de las obras desde el taller a la zona de exposición se realizará en cajas especiales climatizadas.

A continuación establecemos unas breves consideraciones, basadas en indicaciones de Ana Sáenz de Tejada (2001) sobre control de constantes ambientales según el material de la obra expuesta.

\footnotetext{
${ }^{4}$ Nosotros estableceremos un limite máximo de 20 personas en sala

${ }^{5}$ La sala de exposiciones temporales tiene dos accesos o puertas. La de mayores dimensiones que da al hall-será utilizada de entrada; la menor -en el Callejón del Aire-, de salida. Ambas contarán asimismo con dos puertas: 1) la actual, de seguridad y 2) una acristalada, que hará de cápsula cerrada de la sala para mantener las condiciones climáticas deseables, mediante la apertura y cierre automático con células fotoeléctricas
} 
Así, si nuestra exposición temporal muestra bienes textiles (alfombras, tapices, simpecados...) la humedad relativa deberá oscilar en tomo al 55\%; a partir del $65 \%$ de humedad se favoreceria la proliferación de microorganismos del ambiente, mientras que los cambios bruscos en estas condiciones, tanto dia-noche como estacionales, podrian dar lugar a cambios dimensionales y estructurales y reacciones quimicas que acelerarian el envejecimiento del tejido. En cuanto a la temperatura, estrechamente ligada con la humedad relativa, debemos decir que actúa acelerando o retardando la actividad biológica y las reacciones químicas, por lo se recomiendan valores en torno a los $18^{\circ} \mathrm{C}$, con variaciones de $1^{\prime \prime} 5^{\circ} \mathrm{C}$. También habrá que controlar el polvo, la suciedad y los agentes contaminantes, que producen daños tanto físicos como químicos (por ejemplo, roturas de fibras), así como los ataques biológicos (de polillas, escarabajos, etc.). Estos últimos podrán ser controlados aislando las piezas, llevando a cabo una estricta limpieza y estableciendo bajas temperaturas.

Si son metales lo que exponemos, la humedad relativa no deberá superar el $40 \%$. Cuando la humedad relativa de la atmósfera sobrepasa el $100 \%$ y la temperatura del metal desciende por debajo del punto de rocío (la temperatura ideal seria de $18^{\circ} \mathrm{C}$ ), se forma una fina película de agua sobre la superficie de la pieza que actúa como electrolito, provocando la corrosión. Los contaminantes atmosféricos sólidos pueden ser muy perjudiciales. El principal problema del polvo es que retiene y absorbe humedad, por lo que se recomienda eliminar el polvo de las piezas metálicas periódicamente, con un paño suave de algodón. La mejor forma de exponer piezas metálicas es en vitrinas sin polvo, y unas condiciones de humedad y temperatura estables, en los parámetros señalados anteriormente; de no ser así, los materiales óptimos de contacto con el metal seria el PVC o el metacrilato, muy estables químicamente.

Dibujos, acuarelas, libros, pasteles, gouache, grabados, estampas, manuscritos, fotografias y pergaminos... En caso de exposiciones temporales de documentos gráficos -papel- se recomienda una temperatura de entre 4 y $5^{\circ} \mathrm{C}$ para las fotografias, mientras que el resto de documentos permanecerán estables si se respeta un valor en torno a los $18^{\circ} \mathrm{C}$. La humedad afecta de forma directa sólo en casos extremos: un aumento por encima del $65 \%$ de HR favorecerá el desarrollo de los agentes bióticos, mientras que la falta de humedad junto con altas temperaturas acelerará el envejecimiento natural del papel, que amarillea y se resquebraja. Entre los factores biológicos dañinos para el papel, destacan los hongos, bacterias, insectos y roedores; impediremos su proliferación si evitamos niveles de humedad superiores a $70 \%$ y mantenemos una ventilación adecuada.

Finalmente, la conservación preventiva de pintura establece como parámetro fijo de temperatura $18^{\circ} \mathrm{C}$ y de humedad $55 \%$. Mantener una temperatura estable con fluctuaciones diarias que no superen $1,5^{\circ} \mathrm{C}$ es lo más conveniente. En cuanto a la humedad, ésta es un factor de alto riesgo para la pintura sobre tabla, ya que la madera es un material higroscópico y los cambios en la humedad relativa producen alteraciones dimensionales -la madera se hincha cuando absorbe humedad y se encoge al secar-, apareciendo grietas y fisuras. La contaminación es otro factor de importancia, 
que habrá que controlar, pues el aire contiene sustancias gaseosas como óxidos de earbono o de azufre y partículas metálicas sólidas que provocan reacciones químicas. Los microorganismos o esporas y el polvo del ambiente se adhieren a las superficies pictóricas, oscureciendo el conjunto y acelerando el envejecimiento. 


\subsection{CONTROL DE LA ILUMINACIÓN}

La luz, radiación electromagnética, presenta diferentes longitudes de onda que habrá que controlar: especialmente, las longitudes ultravioletas e infrarrojas, que presentan graves efectos dañinos para algunos materiales, tales como dilataciones, aumento de la actividad biológica o modificación de la humedad relativa. El daño dependerá, a grandes rasgos, de:

. cantidad de radiación visible . tiempo de exposición

. la longitud de onda

. la capacidad de absorción del material

En función de estas variables (SÁENZ DE TEJADA, 2001), en exposiciones de textiles, no sobrepasaremos los 40 lux, ya que la luz produce un efecto de fotooxidación en el tejido lo que implica su envejecimiento acelerado y posibles cambios o pérdidas de color. Hay que indicar sin embargo que estos valores tan bajos están destinados a preservar los colores más inestables, que generalmente están en la gama de los rosados o naranjas, aunque colores como el azul índigo soportan niveles de hasta 80 lux. La luz natural, por su alta concentración de rayos ultravioletas, es preferible sustituirla por luz artificial y el uso de filtros ultravioletas. Si esto no es posible se intentará al menos que la iluminación sea la misma en toda el área del tejido para evitar alteraciones parciales, y evitar la luz directa del sol alejando el tejido de las ventanas. En el caso de iluminación artificial, se recomienda por esta misma razón el uso de filtros difusores. La iluminación por fibra de vidrio reúne todas estas caracteristicas.

Para los documentos gráficos la luz es una causa importante de alteración. Por ello es conveniente reducir el tiempo de exposición y respetar la intensidad de luz recomendada en cada caso. Esto es más fácil conseguirlo mediante luz artificial. La fibra óptica se adapta perfectamente a estas exigencias. Los parámetros a tener en cuenta sería los siguientes: acuarelas, pasteles, gouache, dibujos, estampas, manuscritos, pergaminos, grabados en color y fotografias, un máximo de 50 lux. Los grabados en blanco y negro, un máximo de 150-200 lux. Y no más de 75 micro watios/lumen de radiación UV.

Se estimarán 200 lux para iluminar las esculturas y 150 lux para las pinturas al óleo y 50 lux, si son al temple. Los filtros para radiaciones, limitar la exposición a la luz el mayor tiempo posible, una luz difusa que afecte por igual a toda la obra y el respeto por los valores antes indicados son algunas medidas preventivas a tomar. La luz artificial por fibra de vidrio se adapta perfectamente a estos requerimientos. 


\subsection{PLAN DE SEGURIDAD}

Ya que los bienes intervenidos que se van a mostrar van a estar expuestos, al menos potencialmente, a una serie de riesgos que es necesario prevenir, la protección y seguridad de las salas de exposición temporal resulta una obligación para los responsables del Centro de Interpretación del IAPH.

En el ámbito de la intrusión, la legislación aplicable y de no obligado cumplimiento es la Ley 23/1992 de 30 de julio, de Seguridad Privada y el Real Decreto 2364/1994 de 9 de diciembre, Reglamento de Seguridad Privada. En el de incendios -de obligado cumplimiento- se aplicará la Norma Básica NBE-CPV/96 y el Reglamento de Instalaciones de Protección contra Incendios (DOMíNGUEZ PILA, 2000).

El Plan de Seguridad para la zona de exposiciones temporales será integrado en el Plan de Seguridad existente en el IAPH. De esta manera, y siguiendo el modelo de seguridad general de la institución, el sistema de seguridad de la sala de exposiciones estará definido por (PEREZ DEL CAMPO, 1996:55-56):

- Protección interna: con detectores volumétricos de doble tecnología (Doopler e infrarrojos), además de un detector contra aperturas y otro contra aperturas con golpes de tipo magnético.

. Circuito cerrado de televisión, manual y automático, y que funcionará, además, en consonancia con el sistema de detección.

. Puertas blindadas de $190 \times 80 \mathrm{~cm}$.

. Vigilancia presencial: se dispondrá de los servicios de una empresa de seguridad, durante las 24 horas del día, para la vigilancia de las instalaciones y control de los sistemas de seguridad e incendios.

Lógicamente, todos los datos procedentes de este sistema de seguridad en sala confluirán en la Estación autónoma STA-128, centralizadora y procesadora de todos los datos, incluidas alarmas, de la seguridad del IAPH.

Por otro lado, habrá que asegurar la corriente eléctrica con un generador de energía de reserva para 48 horas. Además, se establecerán en la sala dos alumbrados: a) de emergencia, por si falta el alumbrado, con una autonomía de una hora y dos fuentes de alimentación y b) de señalización (de puertas, pasillos, escaleras y salidas de emergencia), siempre encendido, mientras el edificio esté ocupado.

En cuanto a las medidas de protección contra incendios -la amenaza más seria a la que podemos enfrentamos- utilizaremos el equipo central de recepción de alarmas del IAPH -del tipo microprocesado en rak de "19" con terminal de mando centralizado, modelo 664-F Fichet (PEREZ DEL CAMPO, 1996:55)-, detectores iónicos y sirenas. En 
este sentido, los elementos de extinción ${ }^{6}$ (automáticos: una estación de extinción por halón 1301 modelo CEF2 Fichet, y manuales: dos extintores de $\mathrm{CO}_{2}$ y polvo polivalente) deberán estar señalizados, visibles y accesibles.

Otras consideraciones de carácter general serán:

. se utilizará para revestimientos y pavimentos, materiales no inflamables (clase M1). . el vestibulo dispondrá de espacio suficiente para asegurar la fluidez de la circulación de visitantes, permitir la reunión y orientación de los grupos, especialmente de los escolares y evitar la sensación de laberinto. Habrá igualmente orientación y señalética, con carteles bïen visibles (DOMINGUEZ PILA, 2000).

. se dispondrá también de un botiquín cerrado, cuyo contenido ha de ser controlado regularmente por personal o vigilantes que puedan dar primeros auxilios, en caso de accidentes fortuitos (DOMÍNGUEZ PILA, 2000).

. se especificarán limites máximos de personas: 60 personas máximo en el recorrido del centro de visitantes (hasta llegar a la tienda), 20-25 en sala de exposiciones temporales y 30 en talleres didácticos.

- los elementos del montaje expositivo (vitrinas, plataformas, etc.) deberán ser estables y sólidos, para asegurar los objetos en sus soportes.

- el sistema de luminarias deberá estar separado de los objetos y tener buena ventilación, evitando la acumulación del calor y por lo tanto el sobrecalentamiento con posibilidad de incendios.

. en la medida de lo posible, se utilizarán las vitrinas como barrera fisica protectora del objeto contra vandalismos y robos. Otras veces se colocarán barreras psicológicas: cordones, lineas en el pavimento...

${ }^{6} \mathrm{~A}$ ellos hay que sumar las bocas de incendios equipadas (BIES) de que dispone el IAPH 
6. SISTEMA DE DOCUMENTACIÓN 


\subsection{OBJETIVOS BÁSICOS DEL PROGRAMA DE INVESTIGACIÓN}

El Centro de Interpretación del Instituto Andaluz del Patrimonio Histórico, y éste será uno de sus rasgos más peculiares pero también más interesantes, no pretende ser un simple centro de visitantes, un centro de estricta recepción de público. El Centro de Interpretación, busca hacerse un hueco en la dinámica investigadora que representa, caracteriza y fundamenta la institución que lo crea y alberga, el IAPH.

Desde este punto de vista, el Centro de Interpretación ha de contar, progresivamente, en dos fases, con un sistema de documentación radicalmente investigador y científico, con aspiraciones de hacerse cargo de un conocimiento y de una información hasta ahora no centralizada ni sistematizada. La recogida de datos, su análisis y valoración, la informatización de la información y su transmisión y difusión protagonizan la labor de este sistema de documentación que estamos describiendo y que se define en función de tres líneas de actuación básicas:

\section{a. EL CONOCIMIENTO DEL INSTITUTO ANDALUZ DEL PATRIMONIO HISTÓRICO}

La realización de un archivo sobre el IAPH es la primera de las vías de investigación posibles para la creación de un sistema de documentación del Centro de Interpretación, un sistema que, de algún modo, intentará aunar toda la información posible preferiblemente textual y en cualquier soporte- acerca del Instituto Andaluz del Patrimonio Histórico. La historia de la institución (no ya tanto de su sede), su evolución en progresión casi aritmética, su trayectoria en los ámbitos de la documentación e intervención patrimonial, asi como en cuestiones de formación y comunicación, su funcionamiento y su estructura de trabajo, sus actividades principales y productos más destacados, sus servicios y relaciones institucionales, sus convenios de colaboración y programas internacionales, sus éxitos y fracasos, su filosofia y misiones -materializados todos en textos, informes, fotografias, carteles, diapositivas, documentos, publicaciones, etc.- serán documentados y convenientemente archivados. En definitiva, se creará un archivo que complementará los dos archivos existentes en la institución acerca de aspectos relacionados directamente con la propia institución: el archivo de imágenes sobre la sede y el archivo de intervenciones realizadas por el centro de intervención del IAPH.

\section{b. LA INVESTIGACIÓN Y DOCUMENTACIÓN VINCULADAS A ASPECTOS DE COMUNICACIÓN Y DEL PÚBLICO VISITANTE DEL IAPH}

En esta segunda línea de investigación se indagará en la relación IAPH / público como factor de desarrollo de una institución en su etapa de madurez; la vinculación del 
Instituto Andaluz del Patrimonio Histórico con la sociedad, tan deseable y deseada, será objeto de rigurosa evaluación y documentación. Estudios de perfiles de visitantes', bases de datos de públicos, informes procedentes de encuestas de opinión, análisis de satisfacción de expectativas, trabajos de observación de comportamientos de visitantes en salas servirán de estímulo y de evaluación a los responsables del Centro de Interpretación, pero también serán cruzados y analizados, evaluados y publicados posteriormente, con objeto de poder ofrecer al usuario interesado importantes datos acerca de la proyección social de la institución. Por supuesto, y enlazamos con el segundo apartado de este punto de investigación, estas bases de datos incluirán también otros aspectos más generales relacionados con la difusión del Centro de Interpretación y del Departamento de Comunicación del IAPH, entre ellos las estrategias y modos de mediación (podrian documentarse publicaciones, exposiciones, congresos, jornadas de puertas abiertas, seminarios... e incluso textos sobre difusión, marketing o comunicación aplicada al ámbito patrimonial).

\section{c. INVESTIGACIÓN Y DOCUMENTACIÓN SOBRE LAS TEORIAS Y PRACTICAS DE LA INTERPRETACIÓN DEL PATRIMONIO}

Disciplina, técnica o herramienta la interpretación del patrimonio entendida como modo de comunicar aspectos patrimoniales al público general está poco evolucionada en su teoría en sus códigos, en su filosofia. Cada vez con mayor frecuencia -es también de destacar- está desarrollando sus aspectos de materialización o prácticos.

Sea como teoría o como práctica, la interpretación del patrimonio es un área del saber que necesita un abordamiento científico y de investigación con rigor, que sea de utilidad para delimitar su área de proyección, sus objetivos y métodos. La interpretación, definitivamente, necesita ser conceptualizada. Y el sistema de documentación del Centro de Interpretación podría ser un buen foro de debate y de investigación acerca de esta herramienta difusora, al tiempo que el IAPH veria cumplidos sus fines de servir de modelo en el territorio -esta vez, claro está en las tareas de la teorización interpretativa.

\footnotetext{
'En este apartado se estudiarán tanto los visitantes del Centro de Interpretación como el público especializado que realiza visitas técnicas al Instituto, pues sólo de esta manera podremos obtener datos globales y demostrativos del público del IAPH.
} 


\subsection{JUSTIFICACIÓN DE LA ELECCIÓN DE UN SISTEMA}

Debido a la peculiaridad del sistema, que es prácticamente en su totalidad imposible de trasladar a fichas de catalogación, se elegirá un sistema de documentación informatizado repartido en documentos de Word (.doc) o Access (.mdb), según la adaptabilidad del tema al sistema de bases de datos. En cualquier caso, será necesario un modo de vinculación entre los documentos de Word y de Access que estén interrelacionados.

Por otra parte, el sistema informatizado no impedirá la realización de un sistema manual, con textos e imágenes en papel. El primero servirá para realizar búsquedas con rapidez y eficacia, para organizar el cúmulo de información adecuadamente; el segundo, para ofrecer al usuario la posibilidad de visualizar, manipular o reproducir partes del sistema que sean de su interés.

La transmisión al usuario de los datos del sistema de documentación, en sus tres líneas de investigación, será de carácter gratuito. La solicitud o petición de información podrá realizarse en el Departamento de Comunicación del IAPH, presencialmente, vía teléfono, fax o correo electrónico. En la medida de lo posible, el sistema de documentación-investigación será difundido a través de la web del Instituto. 


\subsection{MEDIOS HUMANOS NECESARIOS PARA SU PUESTA EN MARCHA Y MANTENIMIENTO}

El sistema de documentación e investigación del Centro de Interpretación del IAPH contará con un responsable (responsable de investigación-documentación según se describe en el, capitulo de personal) que será el encargado de desarrollar las tareas de investigación y documentación más arriba señaladas, asi como de supervisarlas y lograr su máxima difusión.

En una primera fase del Centro de Interpretación, será el encargado superior del centro quien tenga el deber de iniciar estas tareas documentales, abriendo asi una vía de desarrollo que será abarcada posteriormente por el responsable de investigacióndocumentación.

En la ejecución de las actividades investigadoras se podrá contar con la colaboración de otros técnicos de la institución, de las administraciones de cultura o de profesionales independientes que quieran aportar su conocimiento al sistema de documentación, en cualquiera de sus tres orientaciones. 


\subsection{MEDIOS TÉCNICOS NECESARIOS PARA SU PUESTA EN} MARCHA Y MANTENIMIENTO. JUSTIFICACIÓN DE SU ELECCIÓN

Para la puesta en marcha de las tres vias de investigación propuestas para el sistema de documentación (IAPH, comunicación en el centro de visitantes y teoría de la interpretación) será suficiente contar con un equipo informático Intel Pentium III 933 $\mathrm{MHz}$ de -como mínimo- $64 \mathrm{MB}$ de memoria RAM, disco duro de $20 \mathrm{~GB}, 4 \mathrm{MB}$ de VRAM (memoria vídeo) y conexión a internet. Deberá incluir también los programas del paquete Office de Windows (sistema operativo Microsoft Windows 98), especialmente Word y Access, programa de bases de datos éste último en el que se trabajará con mayor asiduidad.

Entre los medios técnicos se incluye también un escáner tipo ScanPartner 300C Fujitsu, con alimentador automático para unos 50 documentos y una velocidad de 10 ppm.

Igualmente, hará falta una impresora a color tipo Hewlett Packard Deskjet 600. 


\subsection{ESTIMACIONES TEMPORALES PARA SU PUESTA EN MARCHA}

Como se ha dicho anteriormente, la puesta en marcha del sistema de documentación está prevista en dos fases.

La primera de las fases (fáse de avance) comenzará a los tres meses de la apertura al público del centro de visitantes, y estará dirigida por el responsable del Centro de Interpretación, quien tendrá a su cargo el arranque y delimitación de los programas de investigación, además de la especificación de las líneas generales de funcionamiento del sistema de documentación. Asimismo, en esta primera etapa, se establecerán los contactos con instituciones, empresas, profesionales, con objeto de lograr convenios de investigación o colaboraciones puntuales.

La segunda fase (fase de proyección), ilimitada en el tiempo, se iniciará al año de haberse inaugurado el Centro. En ese momento, se contratará a un profesional con perfil de investigador y de relaciones públicas, con formación en patrimonio y experiencia en documentación, que será responsable del área denominada investigación-documentación. Esta persona continuará el trabajo iniciado, alcanzando el máximo nivel de desarrollo posible de las tres líneas de trabajo fijadas, cuyos resultados serán evaluados al año de haber comenzado la segunda fase del sistema de documentación. La evaluación del cumplimiento de objetivos de investigacióndocumentación servirá para erradicar las deficiencias encontradas y maximizar los esfuerzos dedicados a la protección del sistema.

En definitiva, podemos establecer estas previsiones temporales:

apertura Centro 1 año 2 años

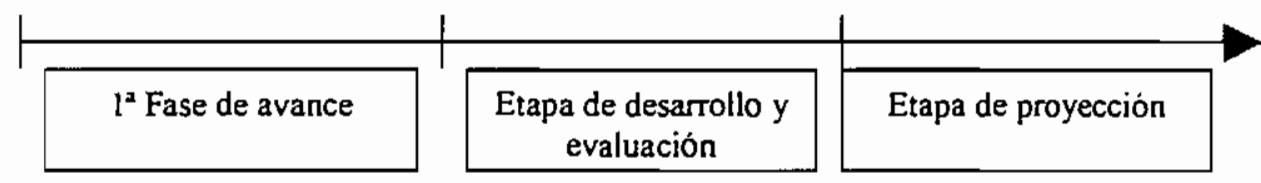

$2^{\mathrm{a}}$ Fase de proyección 


\section{PROGRAMA DE PUBLICACIONES}




\subsection{ENUMERACIÓN}

El Centro de visitantes del Instituto Andaluz del Patrimonio Histórico tiene a su disposición un programa de publicaciones -supeditado al área de Publicaciones del Departamento de Comunicación del LAPH- que presenta dos focos de atención:

1. publicaciones ya existentes, elaboradas por el Departamento de Comunicación desde hace años y ahora pueden ser difundidas (a través de la tienda-librería) y utilizadas (mediante los talleres didácticos) por el Centro de Interpretación. Este material se concreta en:

- Boletin PH

- Colección Cuadernos

- Colección Cuadernos Técnicos

- Publicaciones/traducciones

- Publicación $10^{\circ}$ Aniversario

- Video institucional

- CD-Roms

- Folletos informativos

2. Nuevas publicaciones o materiales, ideados y pensados expresamente para ser aprovechados y difundidos en el centro de visitantes:

- Folleto informativo para visitantes

- Guia explicativa para visitantes

- Gúa didáctica para profesores

- Cuaderno didáctico del profesor

- Cuaderno didáctico del alumno

- Cuaderno de diapositivas para profesores

- Programa didáctico para ordenador

- CD-Rom interactivo

- Exposición del IAPH en maletín

- Pegatinas, carteles, láminas, posters, libretas 
Provecto para un centro de interpretacion del Instituto Andalnz del Patrimonio Histörico

\subsection{DESCRIPCIÓN}

Entre las publicaciones existentes del IAPH, destaca el Boletin PH. En su editorial $\mathbf{n}^{\circ}$ 25 (1999), $P H$ se describía como "una revista institucional dedicada al patrimonto histórico en todas sus vertientes, que ha sabido consolidar un perfil marcadamente profesional e independiente, aunque ello pueda parecer incompatible con un producto relacionado con la Administración. Se trata de una de las pocas publicaciones de estas características editadas en Europa y casi la única generada desde las estructura de una administración autonómica de cultura". En este mismo sentido se pronunciaban profesionales de reconocido prestigio en el ámbito patrimonial. No hay modo mejor para describir la revista que sus opiniones:

Mi opinión acerca del papel que juega hoy el Boletín del Instituto Andaluz del Patrimonio Histórico no puede ser otra sino la de considerarla uma publicación imprescindible dentro del mundo de los que, de una forma " otra, tratamos de acercarnos a la compleja problemática que rodea todo lo referente el patrimonio cultural andaluz

(Juan Agudo Torrico, profesor de Antropologia de la Universidad de Sevilla)

La llegada a casa de cada mevo mímero de PH atiza esas esperanzas, a veces ya en pura brasa. Poder leer reflexiones ajenas, conocer propuestas, comparar experiencias, concebidas y expuestas en clave propia (propia de ese espacio cultural comin auin sentido y reivindicado) es un privilegio.

(Antoni González,

Servicio del Patrimonio Arquitectónico Local, Diputación de Barcelona)

La relevancia de las ideas presentadas, las memorias revividas, asi como de los documentos y articulos descritos, ha trascendido las fronteras de Andalucia y con creces se han constituido en una aportación siempre esperada por estudiosos en los distintos continentes.

(Miguel Ángel Corzo,

Director The Getty Conservation Institute)

Las revistas dan información e incitan a la reflexión y, junto a los periódicos, son los medios más importantes de formación permanente de la sociedad. PH se ha consolidado como la revista más imporiame en este campo

(Eusebi Casanelles,

Director del Museo de la Ciencia y de la Técnica de Cataluña) 
Provecto para un centro de interpretacion del Institulo Andaluz del Patrimonio Historico

El Boletin del lAPH que nace casi como un fanzine (e)l diciembre de 1992). ha pasado de una recopilacion de actividades y uma simación del panorama sobre el Patrimonio, a convertirse en una buena revista especializada, seria, cada vez más exigente en las colaboraciones, con aportaciones técricocientificas sobre intervenciones o proyectos, un necesario pumo de referencia en materia bibliográfica en una agenda informativa exhaustiva para los profesionales, y sobre todo ,cada vez más, decidida a ser un foro plural.

(José Carlos Roldán,

Restaurador, Centro Andaluz de Arte Contemporáneo)

Los Cuadernós y Cuadernos Técnicos, las otras publicaciones destacadas de la línea editorial del IAPH, son monografias sobre aspectos concretos relacionados con el patrimonio. Mientras que los primeros tienen un carácter más teórico, procedente de investigaciones en profundidad, los segundos se asemejan a manuales prácticos sobre temas de naturaleza más experimental. Estos son los títulos de algunos cuademos y cuadenos técnicos: Un proyecto para la Capilla Real de Granada, La Carta de Riesgo, Conservación Arqueológica, Arquitectura y Patrimonio, Patrimonio y Ciudad, Catalogación del Patrimonio Histórico, Difusión del Patrimonio Histórico, Patrimonio Etnológico. Nuevas perspectivas de estudio, Procedimientos de análisis documental automático. Prevención de riesgos laborales en la investigación $e$ intervención en Patrimonio Histórico...

La publicación realizada con ocasión del $10^{\circ}$ aniversario del IAPH, Innovar desde la memoria, también forma parte del corpus de materiales que serán utilizados. Se trata de un material de explicación general de la institución.

Por otro lado, hay que destacar la existencia de publicaciones que, sin ser exclusivamente editadas por el IAPH, forman parte de su colección. Se trata de traducciones de manuales de restauración -existentes en otros idiomas- en las que el IAPH colabora con una editorial especializada. Hasta el momento se han publicado: $L a$ biología en la restauración, Ciencia y restauración y Los insectos y sus daños en la madera.

Los folletos informativos pueden ser de gran versatilidad. Existen dos folletos acerca de la institución, en dos tamaños y calidades diferentes; además, se ha publicado un folleto especifico del Centro de Arqueología Subacuática y otro, en colaboración con el Centro de Documentación del IAPH, acerca del SIPHA, Sistema de Información del Patrimonio Histórico de Andalucia.

Dejando a un lado las publicaciones en papel, hay que destacar la existencia del vídeo institucional, de una duración aproximada de 14 minutos. Se trata de una cinta de audio y video muy atractiva para ser proyectada, por ejemplo, en algunos talleres didácticos o en el aula antes de visitar el IAPH. Su contenido, similar al pretendido por el Centro de Interpretación (historia, funciones, servicios, estructura...), es sencillo y concreto, transmitido en un lenguaje claro y sin pretensiones técnicas. 
Los CD-Roms monográficos, difundidos hasta el momento junto a la revista $P^{3} H$, pueden ser un material atractivo para escolares. Son sencillos de manejar y provocan la interactividad. Algunos títulos son Bienes Inmuebles Protegidos en las Capitales Andaluzas y Megalitos de la provincia de Sevilla.

Hasta aqui se han descrito los materiales publicados por el IAPH y que serán de provecho en nuestro Centro de Interpretación. Se podrá contar también con otras publicaciones de la Consejería de Cultura u otras instituciones, como el CD-Rom informativo del Plan General de Bienes Culturales.

Respecto a las publicaciones o materiales realizados ex profeso para el centro de visitantes destacamos la elaboración de folletos informativos para visitantes. Estos folletos, en forma de díptico, serán el primer contacto del visitante con el Centro de Interpretación; se entregarán -gratuitamente- en el hall del IAPH y serán muy elocuentes y atractivos, ofreciendo información de todos los servicios y programas del centro.

Como complemento del folleto, existirá, además, una guía explicativa con más información y explicación de contenidos. Será una guía de mano, con muchas ilustraciones, sencilla de manejar en el recorrido principal y útil para recordar, a la vuelta a casa, lo que se ha visto y los servicios que quedan por conocer. Su precio será módico: 100 pesetas, por ejemplo. De esta manera, daremos un valor superior a lo que ofrecemos y transmitiremos la idea de que la cultura no es gratuita, no es un regalo, sino un servicio que entre todos pagamos.

Para los profesores de educación secundaria que imparten asignaturas relacionadas con el patrimonio se realizará una guía específica, orientada a la didáctica con los alumnos. Será muy útil para visitas de grupos escolares que no tienen la posibilidad o el interés de realizar un taller didáctico.

En el caso de realizar talleres didácticos, los profesores y los alumnos recibirán cuadernos didácticos. El cuaderno del profesor será aparentemente idéntico al del alumno; pero tendrá las actividades resueltas y contará con sugerencias didácticas. Podrá ser acompañado de un cuaderno de diapositivas para proyectar en clase, a modo de recordatorio del recorrido principal de la visita, o de un CD-Rom interactivo de los temas más importantes explicados.

Para los grupos interesados en los talleres didácticos pero que, por problemas de horario, número o cualquier otro tipo, se dispondrá de un programa didáctico para ordenador que el profesor utilizará en sus clases. Será un programa muy sencillo, de definición de conceptos patrimoniales.

Por otra parte, si el motivo de la imposibilidad de hacer el taller didáctico es la distancia geográfica, se enviará al profesor una miniexposición del IAPH en un maletín 
que incluirá un audiovisual para proyectar y posters para colgar en clase a modo de exposición. Los posters estarán basados en algunos paneles fundamentales del recorrido.

Finalmente, materiales de indole más lúdica, como carteles, posters, láminas o libretas con imágenes del IAPH o del Centro de Interpretación (por ejemplo de la instalación de arte contemporáneo El Círculo del Patrimonio) se venderán en la tienda-libreria a modo de objetos de recuerdo. Pegatinas con los mismos motivos se regalarán a los escolares. 


\subsection{FINANCIACIÓN}

Las publicaciones y materiales destinados al centro de visitantes se financiarán con el presupuesto del Departamento de Comunicación del Instituto Andaluz del Patrimonio Histórico, y, dentro de éste, especificamente, a través de las partidas destinadas al propio Centro, de Interpretación.

Se contempla también la posibilidad de establecer colaboraciones con entidades patrocinadoras públicas y privadas para la elaboración de las publicaciones de carácter gratuito, así como la opción de fijar un porcentaje de autofinanciación a través de la venta de publicaciones. 


\section{ESTRATEGIAS DE MARKETING Y COMUNICACIÓN}




\title{
8.1. ESTIMACIONES DE PÚbliCo POTENCIAL
}

\author{
... su razón de ser es el público; \\ la imerpretación está concebida para la gente
}

(MORALES, 1998:76)

El sistema de visitas especializadas al Instituto Andaluz del Patrimonio Histórico empieza a documentarse en 1996. Desde este año y hasta marzo del 2001 se han realizado unas 200 visitas -5.000 visitantes aproximadamente, 25 personas de media por visita- coordinadas por el departamento de Comunicación. El incremento de visitas por año se pone de manifiesto en el siguiente gráfico, donde se observa que en cuatro años (de 1996 a 2000) se ha duplicado el número de visitas. En este sentido, es destacable el excelente impulso que las visitas han recibido en el año 2001. Desde enero a marzo -solo tres meses- del año en curso, el Departamento de Comunicación del IAPH ha coordinado 17 visitas técnicas, más de las recibidas en los doce meses de los años 1996, 1997, 1998 y 1999.

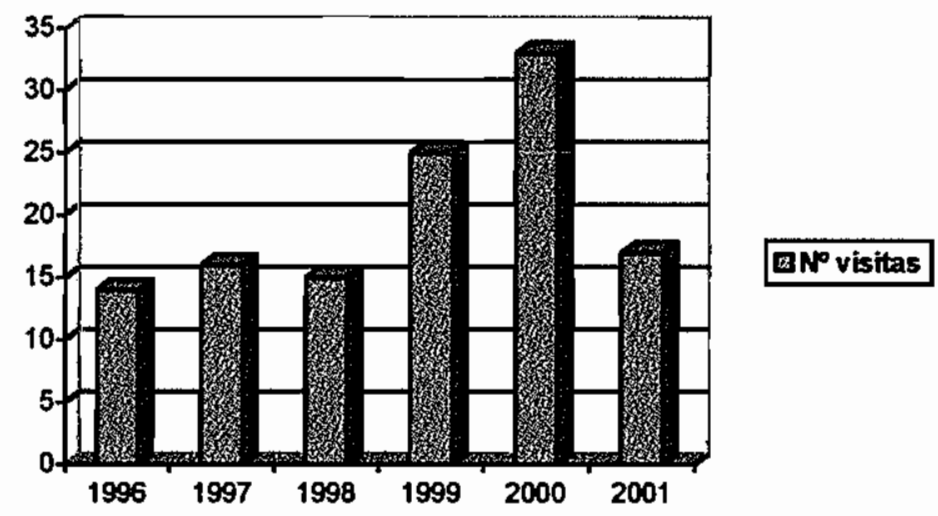

Aparte del decidido aumento, otra característica destacable del público que visita el IAPH es su reincidencia. En el siguiente gráfico se puede ver cómo el $45 \%$ de las visitas que han sido coordinadas por el Departamento de Comunicación del LAPH de 1996 a 2000 son reiterativas, es decir, repiten la experiencia. Obviamente, cuando se trata de visitas de carácter didáctico, se considera reiteración la repetición de la visita por parte del profesor con sus alumnos, aunque éstos sean cada año diferentes. 


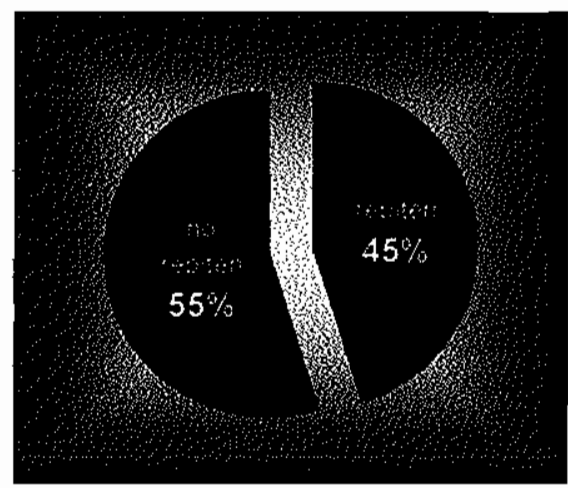

Por otro lado, y como tercera característica del público que visita el IAPH, destaca la procedencia. Los siguientes gráficos analizan el origen de las visitas desde 1996 al año 2000:

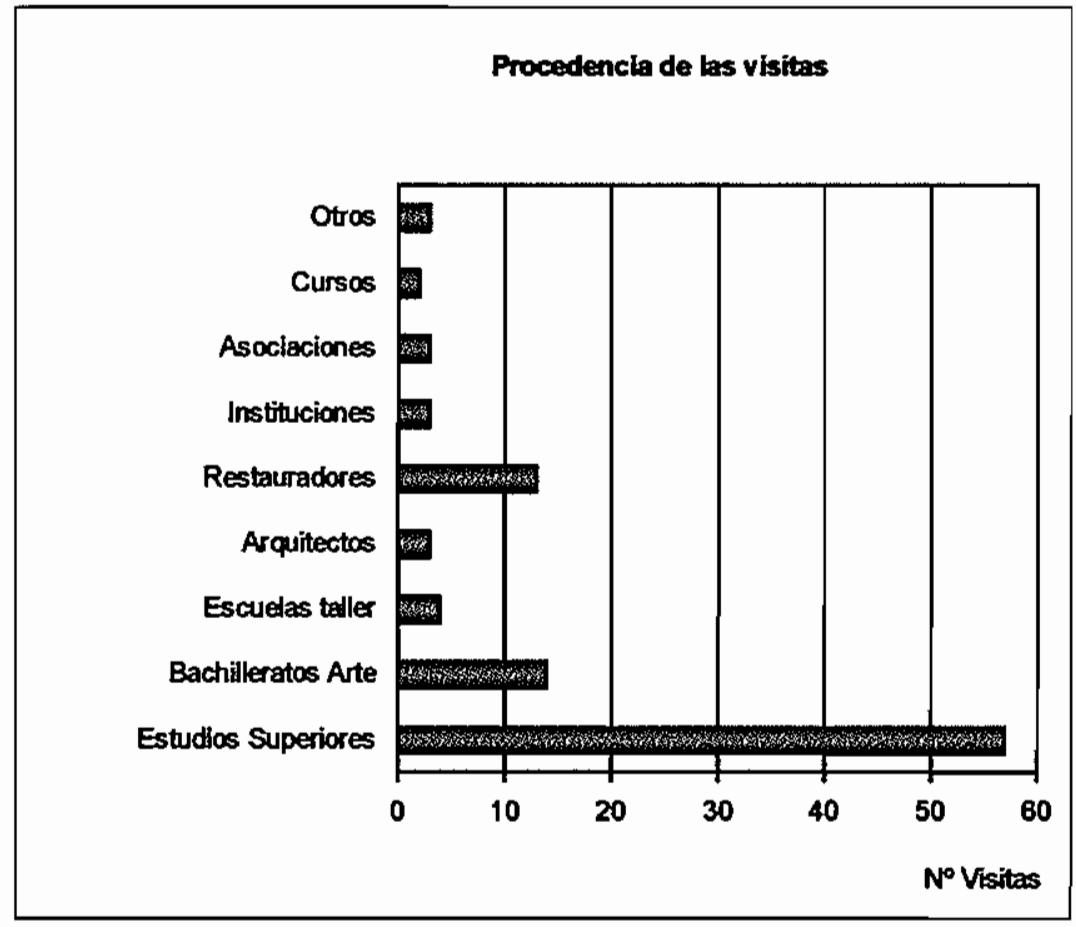




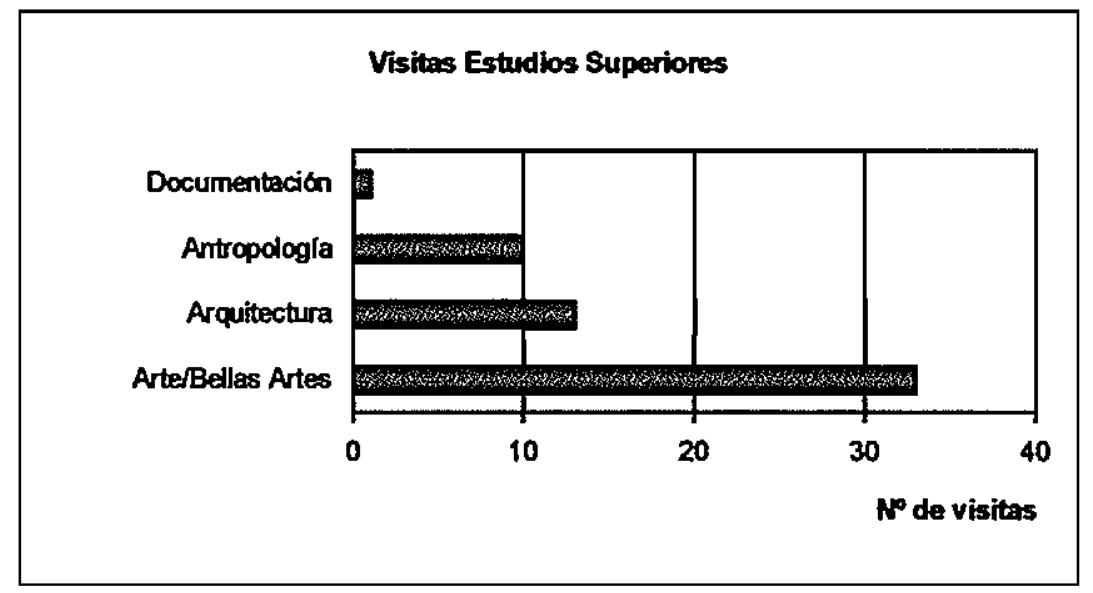

El público prioritario del IAPH son los profesionales del patrimonio y, en relación a las visitas, los futuros profesionales del patrimonio (estudiantes de licenciaturas relacionadas con el ámbito patrimonial, de másters o cursos de posgrado, de terceros ciclos universitarios, etc.). Para estos, el Instituto Andaluz del Patrimonio Histórico cuenta con un sistema de visitas guiadas, que debería reforzarse con la creación de grupos de trabajo más intensivos y especificos según el perfil de los visitantes. Alejarse de la visita guiada tipo turístico y entrar a trabajar con dinámicas de mayor aprovechamiento debe ser el objetivo de trabajo con estos futuros profesionales del patrimonio que deben representar el objetivo, el punto de mira del IAPH en cuanto a público.

Pero bien diferentes son los objetivos y públicos del centro de visitantes, que no anula el sistema de visitas especializado, ya que su público prioritario es el público general o escasamente especializado en cuestiones de Patrimonio. Así, y fundamentalmente, el público potencial del centro se vertebra en los siguientes perfiles:

1. Público que visita el Monasterio de La Cartuja o el Centro Andaluz de Arte Contemporáneo (CAAC). Se trata de un público fácil de enganchar (lo visita todo), que se llevaría el conocimiento de la existencia de una institución, además de una idea de La Cartuja como lugar cultural, como fábrica de la cultura. Hay que contar aquí con un público extranjero que habla otros idiomas.

2. Grupos de carácter general (tercera edad, asociaciones, etc.), que recibirian un tratamiento similar al del público visitante del Monasterio.

3. Público de Bachilleratos (especialmente nos interesa el estudiante de Bachilleratos de Arte y Humanidades, asignaturas de Patrimonio Histórico, Historia del Arte, Geografia...). Es un público que en el futuro puede ser público potencial del IAPH. Nos interesa, pues, más que los anteriores, por lo que se puede trabajar con él, siempre en colaboración con los Gabinetes Pedagógicos de Bellas Artes, encargados y especialistas en la didáctica patrimonial a grupos de estas edades. 
En relación con este público de Bachilleratos de Arte y Humanidades, que es el objetivo número uno del Centro de Interpretación, hay que recordar que, si bien el origen de las visitas a la institución fue esencialmente didáctico-universitario, en la actualidad se viene observando un aumento en el número de solicitudes procedentes de centros de bachillerato (especialmente Bachilleratos de Arte que imparten la asignatura Patrimonio Histórico de Andalucía) que sería interesante fomentar, y sólo se puede fomentar - por razones lógicas de impacto- a través de un centro de visitantes.

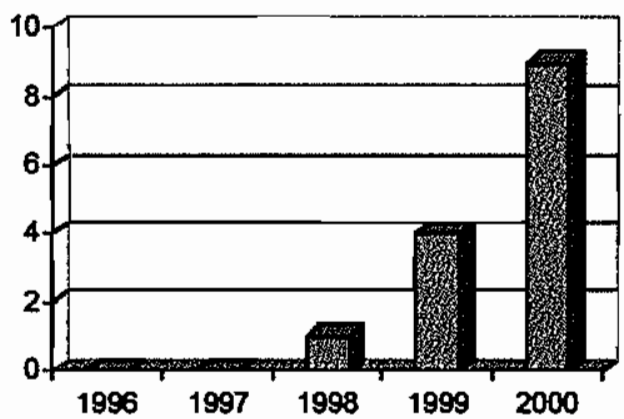

D $N^{P}$ visitas

BACHLLERATOS

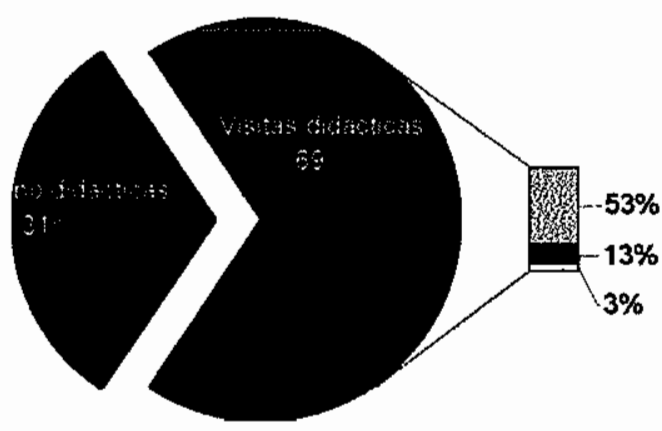

田EstSuperiores

Bach Arte

口Escueles taller 
En los anteriores gráficos se observa cómo -desde 1996 al 2000- el mayor porcentaje de visitas acude desde facultades universitarias, Institutos de Bachillerato u otras instancias pedagógicas y cómo, dentro de este grupo de visitas pedagógicas o didácticas, despuntan las procedentes de Bachilleratos -siempre de Arte o Humanidades. En dos años, se ha pasado de la práctica inexistencia de este tipo de visitas (en 1996 y 1997 no hubo ninguna, en 1998, una) a una evolución de gran proyección, alcanzando en el año 2000 nueve visitas de Bachilleratos, más del doble que en 1999. No es capricho, entonces, que este tipo de visitante - el futuro estudiante de licenciaturas patrimoniales- sea el público objetivo más importante del centro de interpretación del IAPH, precisamente porque, a diferencia de los públicos generales que hemos denominado 1 y 2 , puede ser futuro profesional del patrimonio.

En defunitiva, el centro de interpretación del Instituto Andaluz del Patrimonio Histórico cuenta con los siguientes públicos potenciales:

-público futuro profesional del patrimonio, que seguirá teniendo en las visitas especializadas tal y como están planteadas en la actualidad su modo de vínculo con el IAPH. Quizás sería conveniente establecer con él otras dinámicas de trabajo, pero éstas no tienen cabida en este proyecto al estar ajenas por completo a la realidad que representa un centro de visitantes como el que planteamos.

-público general (visitante del Monasterio o no), que tendrá en el centro de interpretación una oferta cultural más. Atender a este tipo de público desde la institución, mediante un centro de interpretación, es simplemente un modo de dar a conocer la institución a la sociedad en general.

-público estudiante de Bachilleratos de Arte y Humanidades, que representa un público potencial intermedio entre el futuro profesional (que quiere y necesitar ver in situ el funcionamiento de la institución para ver satisfechas sus expectativas de visita) y el visitante-turista (al que no nos interesa retener ni dirigir hacia un más elevado nivel de conocimiento, compromiso o motivación hacia la institución o su ámbito de actuación). El estudiante de Bachillerato es, sin embargo, un público ideal para visitar el centro de interpretación, por su edad, que nos interesa concienciar y por su interés incipiente por el Patrimonio (partimos del hecho de que es un visitante relativamente motivado por esta cuestión, pues ha elegido una opción de Bachillerato de Arte o Humanidades); el centro de interpretación le servirá de acicate, quién sabe, en sus decisiones curriculares inmediatas, ya que en uno o dos años tendrá que elegir licenciatura. 


\title{
8.2. ESTRATEGIAS PARA SU SOSTENIMIENTO Y AMPLIACIÓN
}

\begin{abstract}
La interpretacion es un servicio publico que ha de revelar significados e interrelaciones a una gran diversidad de visitantes. Los cambios que experimenta mestra sociedad conllevan la incorporación de mevos valores.
\end{abstract}

(MORALES, 1999:294)

La interpretación es una forma de comunicación dirigida a quienes buscan esparcimiento, disfrute o cultura -0 nada en particular- en espacios naturales, en el medio rural, en sitios históricos, en jardines botánicos y museos, en itinerarios naturales o urbanos, y en otra gran variedad de sitios poseedores de un valor patrimonial (MORALES, 1998:73). En este sentido, la interpretación se concreta en un proceso comunicativo que, como tal, recurre habitualmente a modelos sencillos de la comunicación para diseñar su aplicación (planificación)" (MORALES, 1998:73); muy apelado sigue siendo el modelo Emisor-Mensaje-Receptor (con progresivas mejoras conceptuales, como la introducción de los términos ruido, redundancia o retroalimentación) procedente del esquema matemático de Shannon y Weber'. Se trata, en definitiva, según este esquema, de entender la exposición, el producto interpretativo como un proceso de comunicación de masas que se plasma en un mensaje estratégico según las necesidades y objetivos de la institución emisora -IAPH- con un lenguaje determinado en función del público al que es destinado y de acuerdo con el contexto espacial y temporal en el que se inserta.

La interpretación se hace, pues, por y para el público, es una forma de atención a los visitantes que parte de algunas premisas, muchas de ellas confluyentes en el concepto de interpretación como instrumento de gestión. Asi, las premisas (HOOPERGREENHILL, 1998:95-96) de que el público tiene derecho a visitar ciertos espacios -en nuestro caso una institución pública que puede resultar de interés por su naturaleza o por el tipo de trabajo que realiza-, que el espacio visitable tiene una determinada capacidad de carga, que el fenómeno de las visitas ocasiona impactos o que hay métodos que pueden controlar esos impactos (el centro de visitantes del IAPH sería uno de estos métodos) llevan a la determinación de entender la interpretación no sólo como un modo de comunicación sino también como un instrumento de gestión de la institución para, fundamentalmente, prevenir los impactos del público, pero también (MORALES, 1999:97-98) para

\footnotetext{
' para conocer aplicaciones de modelos comunicativos a ámbitos museisticos, se puede revisar HOOPER-GREENHILL, 1998:57-79
} 
favorecer la comprension del ustuario por el lugar que visita. brindar mejores oportumidades de disfnite, reducir el incumplimiento de las normas, evirar tenter que recordar y hacer cumplir leyes y normas, mantener la sensación de liberiad del visitante, favorecer a otras unidades de gestionn', poder explicar el papel y las actividades de la institución. de forma que el priblico comprenda la finción de ésta, fortalecer la imagen del organismo como resillado de mas relaciones puiblicas positivas e informar al puiblico

... y un público bien informado está preparado para valorar convenientemente su patrimonio. De alguna manera, como cree entender Mahaffey (1969, citado por HOOPER-GREENHILL, 1998:56), una parte sustancial del esfuerzo de comunicación con el público en sitios con importancia patrimonial pretende desarrollar una conciencia personal del visitante hacia ese patrimonio. Ser consciente puede preparar el camino a una actitud hacia el medio/patrimonio; además, la conciencia debe ir acompañada de un conocimiento... Es aquí donde entra en juego la interpretación del patrimonio.

Pero para emitir su mensaje con eficacia y efectividad, el profesional de la interpretación tiene que conocer las características del visitante $y$, por supuesto, no orientar sus esfuerzos hacia el visitante medio, sino satisfacer diferentes tipos de público. En nuestro centro de interpretación, los variados niveles de lectura de los textos y las actividades diversas con públicos escolares o especiales constituirán, en este sentido, una manera de cubrir el amplio espectro de potenciales visitantes.

De todos modos, como recuerda J. Morales (1999:83), es obvio que "cada una de las personas para las que interpretamos necesita algo diferente: unas quieren ser informadas, otras desean entretenimiento, otras solamente necesitan un poco de atención, mientras que algunas sólo preferirian ser simples observadores". De una u otra forma, el público de la interpretación busca placer, por lo que, si queremos mantener su atención, habrá que proporcionarle cierto grado de disfrute: ofreciendo siempre una apariencia de informalidad, provocando la interacción social, satisfaciendo sus necesidades -fisiológicas, permitiendo el descanso; de orientación; de pertenencia; de autoestima, facilitando el autodescubrimiento, por ejemplo; de conocimiento, etc. (MORALES, 1999:73-74 y 79-81).

Sumada a la visión del visitante turista-buscador de placer, aparece -cada vez con más fuerza- la perspectiva del visitante-consumidor. Vivimos en la sociedad del consumo y hernos de ser conscientes y consecuentes; negar la realidad que nos rodea es ahuyentar, rechazar al público que también nos circunda:

Puede que el arte este por encima de la historia, pero los museos [léase centros de interpretación] no. Estos tienen una finción social. Desde si origen, el museo ha respondido a las expectativas de la sociedad del momento y de stis elites. Ahora estamos bajo el signo de una sociedad de consumo y de

\footnotetext{
${ }^{2}$ Seguridad, mantenimiento, talleres en nuestro caso
} 
la popularización de la cultura, pero el museo se resiste a verse bajo esta mirada. La masificación le prodice tension con la sociedad y la relación con ella está agarrotada por el miedo; miedo a escuchar la voz del priblico y a trastocar el aura museistico-artistica. El dilema eutre lo canónico y lo social del arte debe resolverse con im esfuerzo por escuchar esa voz y responder a sus inquietudes sociales, intelectmales y emocionales. Ast: mientras la producción artistica busca mievas formas de expresión, tambien la relacion enre museo y sociedad las requiere (RODRIGUEZ EGUIZABAL, 2001:34)

En nuestro centro de interpretación, el afán consumista del público se verá satisfecho de un modo que consideramos moderado, equilibrado, no desmesurado ${ }^{3}$. Trataremos así de lograr un equilibrio, de ser respetuosos con modelos patrimoniales no economicistas sin dejar de mirar hacia nuevas visiones, como la de Tunbridge y Ashworth (1996) que, en su libro Dissonant Heritage. The management of the past as a resource in conflict, establecen la definición y descripción de un modelo de parrimonio análogo al modelo industrial recurso/producto/consumo y que presenta el siguiente esquema:

OTROS

RECURSOS

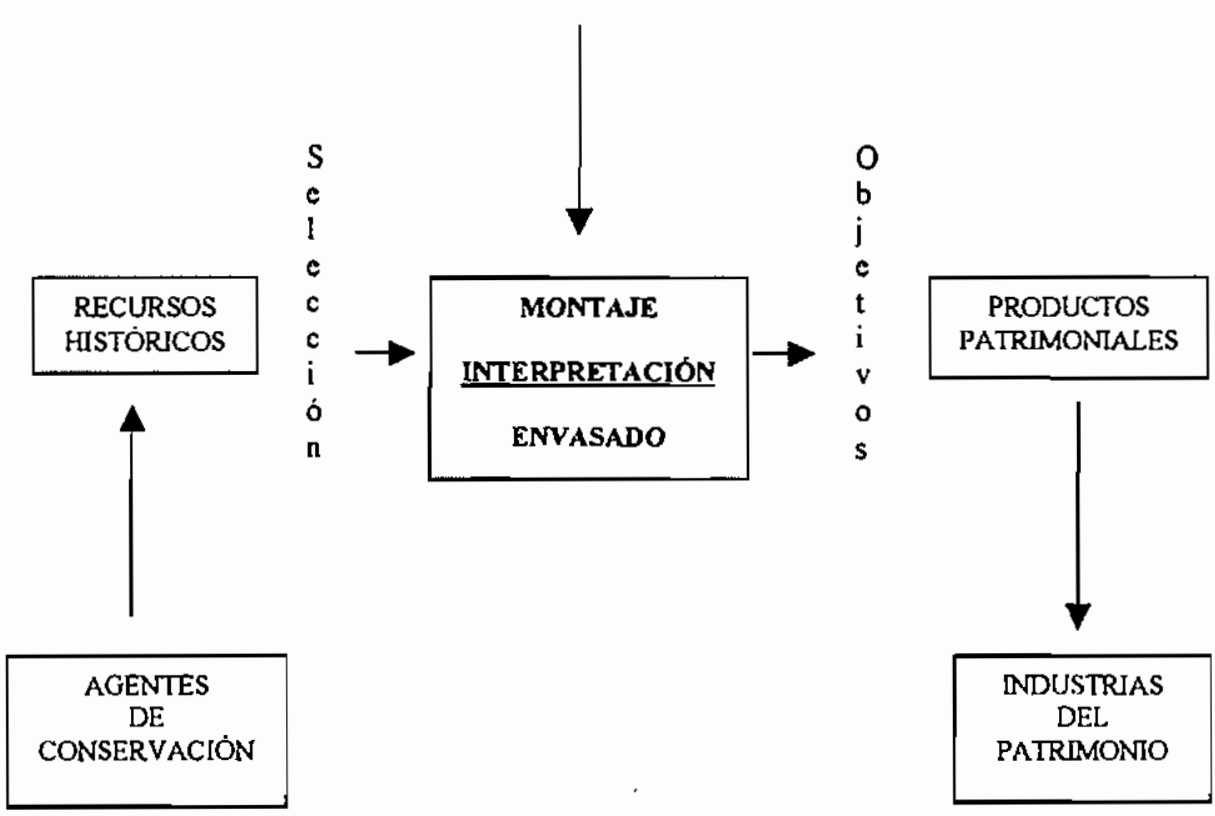

\footnotetext{
${ }^{3}$ Mediante la opción de compra de libros en una tienda-libreria al final del circuito
} 
Este modelo, influido profundamente por las técnicas de marketing, parte, pues, de la constatación de un cúmulo variado de recursos, todos asociados simbólicamente entre sí y sometidos a la estela de la siempre presente conservación, que son seleccionados deliberadamente para adaptarse a un proceso de transformación, de conversión en producto a través de la interpretación. Es obvio, entonces, que el producto resultado de esta transformación no podrá ser nunca sinónimo de los recursos preservados, por la reducción que representa la selección y por la subjetividad que significa siempre una intermediación ${ }^{+}$, pero será al menos un modo de acercamiento a la sociedad, una manera óptima de alcanzar los objetivos de comunicación del recurso que se hayan diseñado.

De este manera, Tunbridge y Ashworth nos plantean un concepto de patrimonio culturalmente construido, que concede al consumidor (visitante, turista, público) un papel en el proceso de producción patrimonial altamente relevante, por la consideración del producto patrimonial como una respuesta a las necesidades específicas de los actuales o potenciales usuarios, y por la existencia de una variedad infinita de posibles patrimonios, tantos como consumidores o como interpretaciones se construyan en función de los requerimientos de los grupos de consumidores especificos que queramos alcanzar.

La naturaleza del producto patrimonial -en nuestro caso el centro de interpretación del Instituto Andaluz del Patrimonio Histórico- es determinada por los intereses y demandas del público, no por la mera existencia de los recursos ${ }^{5}$. De acuerdo con esta idea, el desarrollo del producto será consecuencia de la identificación de los sectores de mercado y sus objetivos, lo que nos obliga forzosamente a realizar unas estrategias y planes de marketing.

Ahora bien, marketing no significa, sencillamente, publicidad. Hooper-Greenhill (1998:37), en relación al ámbito musetstico, aclara el término de este modo:

En algimos museos, el concepto de marketing está limitado al de publicidad o de relaciones puiblicas. Sin embargo, el marketing llega mucho más lejos. A un planteamiento basado en la publicidad le resulta suficiente transmitir información acerca de lo que está sicediendo, asi como el momento y lugar en que sucede. Un planteamiento que utilice métodos de marketing auténticos intenta unir esos "productos" al publico al que pretende dirigirse y se hace preguntas acerca de si el "producto" es adecuado para el "consumidor".

\footnotetext{
${ }^{4}$ En otras ocasiones, la intermediación, además de subjetividad, conlleva acusaciones de sobreinterpretación, trivialidad, deshonestidad, distorsión, elitismo, rigidez, oscurantismo, irrelevancia...., cuestiones todas que hay que controlar

'Esta es ma riqueza colectiva, porque los bienes que lo integran se han convertido en patrimoniales debido exclusivamente a la acción social que cumplen, directamente derivada del espacio con que los mismos ciudadanos los han ido revalorizando (Ley de Patrimonio Histórico Español, Ley I6/1985, del 25 de junio de 1985)
} 
Así, nuestro plan de marketing comenzará obteniendo información sobre el perfil del visitante $^{6}$, el mercado en el que actúa el centro de interpretación, el potencial de desarrollo de los principales segmentos de ese mercado y de las estrategias que se han de desarrollar... Todo ello con la finaididad de aumentar la actual base de clientes o incrementar las visitas de un grupo concreto de visitantes, captar nuevos públicos (SHARKEY, citado por HOOPER-GREENHILL, 1998:228), desarrollar una actividad investigadora determinada. o mejorar la categoria del Centro de Interpretación.

Conforme a estos análisis de público y finalidades u objetivos, establecemos dos tipos de estrategias de marketing y comunicación:

a. estrategias de marketing internas (llevadas a cabo fundamentalmente por la propia institución)

b. estrategias de marketing externas (en colaboración con otros organismos, empresas, instituciones...)

Respecto a las estrategias internas, establecemos estas políticas de marketing:

- POLITICA DE EXPOSICIONES: por la que se establecerán los principios en los que basar las exposiciones, y que servirán de guía a los planes de acción concretos que se elaboren como marco para las muestras previstas en un periodo determinado. La política de exposición se ocupará de definir el público destinatario, los recursos disponibles ${ }^{7}$, los costes y duración, la función de la exposición y su evaluación (HOOPER-GREENHILL, 1998:229). Esta política abarcará la exposición permanente, las temporales e itinerantes (descritas en 8.3., Servicios para el público generai) y procurará proteger y propugnar la identidad del IAPH por medio de los mensajes transmitidos, de forma individual en cada exposición y en la relación que se establezca entre unas exposiciones y otras. La organización de exposiciones temporales se concibe como un modo de reforzar ideas de productividad y de implicación social de la institución y de fidelización del público a través de las

\footnotetext{
${ }^{6}$ Buscaremos conocer, de acuerdo con los puntos reseñados por la Countryside Commission de 1979 (MORALES, 1998:180):

- el tipo de usuario previsto

- los patrones de visita (época, horarios, movimientos)

- la duración de la visita

- el tamaño, estructura y tipo de los grupos

- los grupos especiales (discapacitados, especializados...)

- las características socioeconómicas

- los conocimientos o experiencias previas del visitante

- la procedencia

- el tipo de viaje (de paso, vacaciones, ex profeso...)

- la repetición de la visita

- las necesidades especiales (rampas, espacios para comer...)

- los intereses del visitante (conocimiento, recreación...)

${ }^{7}$ La politica de exposición deberá fundamentarse en el público y no ser una mera distribución de recursos (HOOPER-GREENHILL, 1998:232)
} 
visitas reiteradas; la organización de exposiciones itinerantes para que circulen por Andalucia responde a una estrategia de apertura del IAPH hacia el territorio andaluz.

- POLITICA DE DIFUSIÓN: concretada en el establecimiento de una adecuada señalética ${ }^{8}$ anunciadora del Centro de Interpretación, destinada al visitante que acude directamente al centro (función orientadora) y al público potencial que puede llegar desde el Monasterio/CAAC (función informativa/persuasiva). En un principio se pensó en una política de difusión masiva del Centro de Interpretación entre Institutos de Bachillerato, una difusión de tipo personal, cara a cara con profesores de secundaria de asignaturas relativas al patrimonio, pero se decidió finalmente -tras la contrastación de la idea a través de entrevistas con algunos expertos y profesionales de la institución- que era más aconsejable, por razones de concepto de la institución, que ésta se fuera abriendo a la sociedad al ritmo que ésta lo fuese solicitando. El LAPH, por definición y naturaleza, no tiene la misión de abrirse al público, como un museo o un centro de arte, de difundirse masivamente a la sociedad. Un anuncio de la existencia del Centro de Interpretación en la revista $P H$. Boletín del Instituto Andaluz del Patrimonio Histórico, y el aviso de las exposiciones temporales en la página web de la institución serán suficiente como estrategias de difusión masiva.

- POLITICA DE INVESTIGACIÓN: el área de investigación-documentación desarrollará unas tareas (descritas en el apartado 6.1.) que se utilizarán estratégicamente para mejorar la imagen de la institución en el territorio andaluz, demostrando el interés permanente del IAPH por la investigación y el desarrollo y por la implicación de todos los sectores, administrativos y sociales diversos, en el patrimonio.

- POLÍTICA DE EDUCACIÓN (talleres didácticos): se trata de una estrategia comunicativa cuyo más destacado interés se encuentra en la vinculación del IAPH con un sector social nuevo para él, el de Bachilleratos de Arte y Humanidades, con el que nunca ha establecido relación, a excepción de algunas visitas de grupo. Se percibe como una de las estrategias que más beneficios y satisfacciones puede reportar a la institución, habida cuenta del incremento exponencial de demandas de visitas de este tipo de público y de la experiencia tan interesante que de ellas se ha obtenido hasta el momento. En concreto se buscará a) la colaboración estrecha con la red educativa del territorio andaluz, poniendo el centro al servicio de la labor pedagógica de profesores, especialmente, de Bachillerato y b) la participación, junto a los Gabinetes Pedagógicos de Bellas Artes, en la elaboración de material didáctico de la asignatura Patrimonio Histórico de Andalucía, participando así en la sensibilización del alumnado en la conservación y valoración del Patrimonio.

- POlitica dE ATENCIÓN Al VISITANTE: se perfila como una de las estrategias de mayor importancia, a pesar de su escaso interés temático. De esta política dependerá en buena parte la satisfacción final del visitante, la fijación de contenidos, el recuerdo grato de la visita e incluso su posible repetición. Por estas

${ }^{8}$ Ver apartado 3.6. 
razones, un buen servicio al visitante -tanto de instalaciones como de atención personal mediante guias y vigilantes- será una línea de marketing para trabajar con profundidad.

- POlitica de VOLUNTARIADo: el Centro de Interpretación dependerá de los voluntarios culturales para la realización óptima de algunas de sus actividades, tales como Jomadas de Puertas Abiertas, exposiciones que se prevean masivas o talleres didácticos. Al igual que la atención al visitante, se trata de una política que, bien cuidada y manejada, puede reportar grandes beneficios de imagen y de productividad.

En cuanto al segundo tipo de estrategias marcadas, las estrategias externas, destacamos las siguientes":

- Conexión a los circuitos culturales de las diputaciones, consejería y delegaciones de Cultura, cajas de ahorro, etc.

- Mantenimiento de relaciones permanentes con otros centros de intervención, museos, espacios expositivos, colaborando en proyectos conjuntos

- Establecimiento de relaciones con programas de animación sociocultural

- Conexión con políticas juveniles y sus servicios de información

- Enlace con Ia oferta turística del Monasterio y Centro Andaluz de Arte Contemporáneo

Finalmente, siendo conscientes de que este plan de marketing no se puede limitar a establecer las líneas maestras para el presente, sino que se debe plantear la acción para el futuro inmediato, las políticas de marketing descritas serán revisadas al año de ponerse en marcha, esto es, al año de la inauguración del Centro de Interpretación. Se iniciará entonces una fase de evaluación detenida de las politicas de marketing, de los objetivos y logros, con objeto de ir introduciendo los cambios que sean precisos o que se adapten a nuevas circunstancias.

${ }^{9}$ Basadas en AA.VV., 1995:48 


\subsection{SERVICIOS PARA EL PÚBLICO GENERAL}

El público general del Centro de Interpretación tiene a su disposición varios servicios que se concretan en:

\section{. PROGRAMA DE EXPOSICIÓN PERMANENTE}

El programa de exposición permanente del Centro de Interpretación del IAPH concentra cuatro puntos de interés:

. recorrido principal: se trata del centro de interpretación propiamente dicho y ofrece al visitante la información y explicación del Instituto Andaluz del Patrimonio Histórico, sus misiones, sede, productos, servicios y estructura de funcionamiento. A pesar de la denominación permanente, este recorrido establecerá cambios y modificaciones cuando sean necesarios por razones de contenido (por ejemplo, en los paneles del Departamento de Formación se irá incluyendo información actualizada sobre la oferta de másters, cursos y becas) o por razones de innovación de cara al público que hace visitas reiteradas.

. instalación de arte contemporáneo Círculo del Patrimonio, que, pese a formar parte del recorrido -concretamente es su punto final y culminante-, puede convertirse con el tiempo en un atractivo por sí misma.

. tienda-libreria: para el visitante resulta una posibilidad de consumo cultural. En la tienda-librería se venderán publicaciones del Instituto Andaluz del Patrimonio Histórico, de la Consejeria de Cultura y de asociaciones u organizaciones sin ánimo de lucro de carácter cultural. lgualmente, se venderán guias culturales y pósters o láminas, libretas o carteles sobre imágenes del IAPH o del Centro de Interpretación (por ejemplo, de la instalación de arte contemporáneo El Círculo del Patrimonio).

- cafetería: al final de la visita, se da la posibilidad al visitante de obtener un momento de relajación y descanso, de tomar una consumición y continuar hacia la salida, seguramente, más satisfecho.

\section{. PROGRAMA DE EXPOSICIONES TEMPORALES/ITINERANTES}

Este programa responde a la necesidad de frescura que alertan algunos especialistas, como Jorge Morales (1999:85), que entiende que

Ima manera de satisfacer a los visitantes repetidores seria disponer de programas renovados y frescos. Desde linego que ha de haber unos programas básicos y esenciales de carácter permanente, pero también se puede contar con exhibiciones temporales, folletos diferentes (...), programas de animación, etc. 
En este sentido el Centro de Interpretación cuenta con un programa de exposiciones al margen del recorrido expositivo general que se vertebra asi:

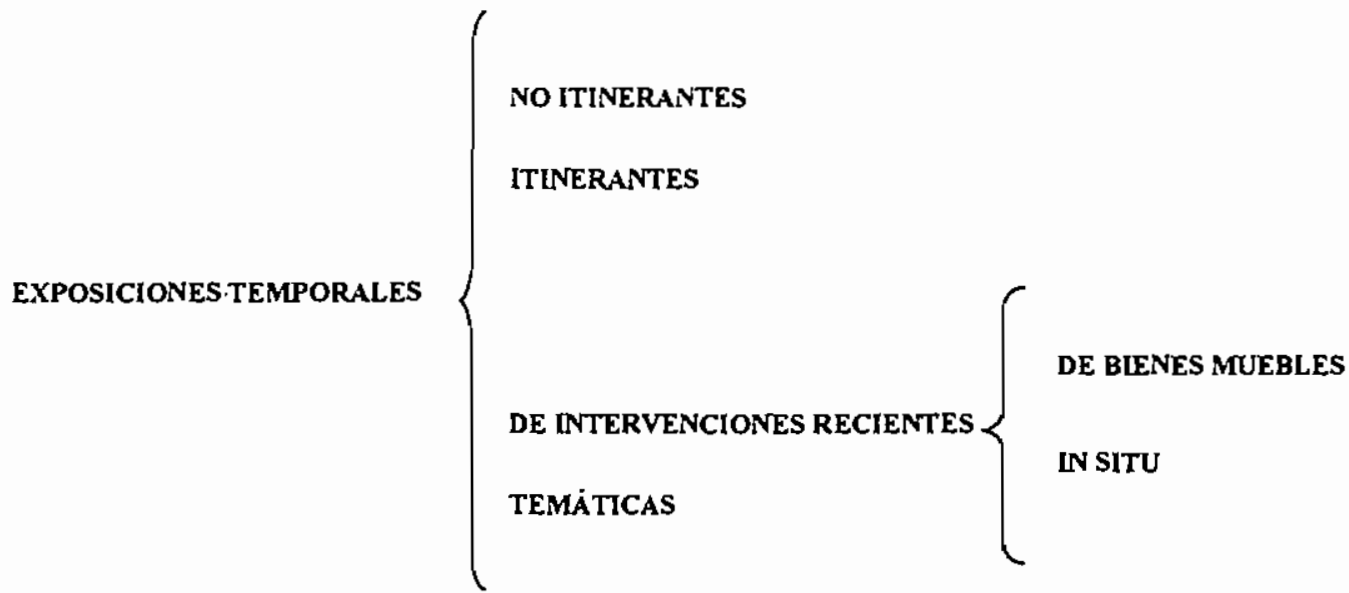

Según el esquema, las exposiciones temporales que definamos podrán tener un carácter más estático, para ser mostradas únicamente en la sala del IAPH, o un matiz de movilidad en el territorio andaluz. Por supuesto, en esta distinción tendrán que ver causas ajenas a la organización, por ejemplo, la disponibilidad ofrecida por los propietarios de las obras intervenidas o la urgencia de éstas por ser expuestas en sus lugares de destino (museos, iglesias, otras exposiciones, etc.). La fragilidad de la obra podrá ser igualmente un motivo para no exponerla de forma itinerante.

En el caso de exposiciones sobre temas diversos, no exactamente relacionados con obras intervenidas -por poner un caso, Exposición del Proyecto Alianzas para la Conservación-, se procurará siempre su itinerancia.

Excepcionalmente, la exposición temporal podrá ser concebida in situ, a modo de interpretación de un objeto inmueble intervenido -la Puerta de Córdoba de Carmona, recientemente intervenida por el IAPH, podría ser un buen espacio para interpretar. Estas exposiciones-presentaciones tienen la ventaja de la duración ilimitada (no hay que trasladar el objeto a su lugar de origen) y la posibilidad de realizarse en cualquier momento (al contrario de lo que ocurte con los bienes muebles intervenidos, que habrán de ser inmediatamente expuestos, antes de que sean despedidos por parte de la institución). También de modo extraordinario se podria hacer alguna exposición in situ durante la intervención para informar al público sobre los trabajos de restauración que se estén llevando a cabo y con objetivos de concienciación y sensibilización para la conservación (NARDI, 1999). 


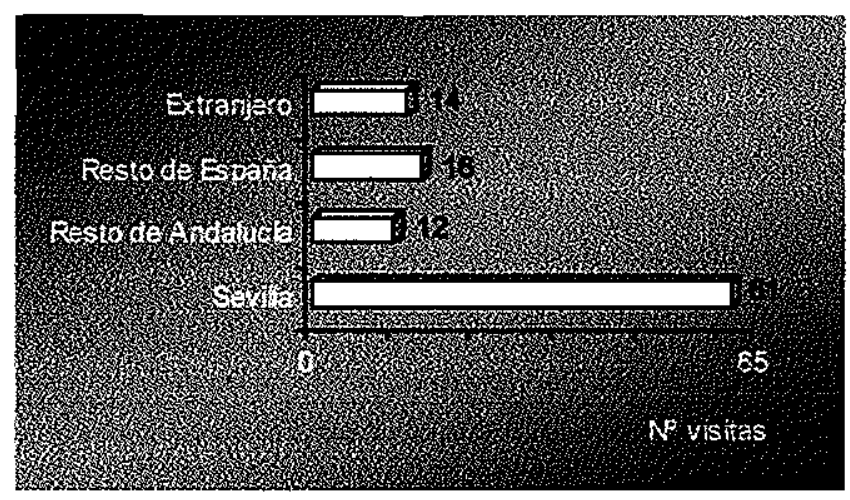

En el cómputo total de visitas, desde 1996 a 2000,14 visitas, es decir, el $13 \%$ de los visitantes eran de grupos extranjeros. Consideramos, a partir de estos datos y de la previsión sobre público potencial visitante del Monasterio de La Cartuja/CAAC, que se hace necesario un programa para público extranjero que se concreta en una guía explicativa en inglés de los contenidos más relevantes explicados en el Centro de Interpretación $y$ en un folleto sencillo, también en inglés, para cada exposición temporal que se organice. 


\subsection{SERVICIOS PARA EL PÚBLICO ESCOLAR}

\section{A los únicos que hay que darles $m$ in tratamiento especial en los programas y actividades interpretativas es a los niños}

(MORALES, 1999:294)

La interpretación destinada a miños requiere $u n$ enfoque radicalmente diferente

$\left(\right.$ TIDEN $\left.^{10}\right)$

Al igual que ocurre en la mayor parte de espacios museísticos, el público escolar según hemos previsto- será nuestro usuario más numeroso, además de ser, en su etapa de bachillerato, uno de nuestros públicos-diana. Desde esta perspectiva, el Centro de Interpretación del IAPH debe contar con unas instalaciones específicas para este tipo de público (descritas en 3.5.5.), además de ofrecer actividades y servicios ajustados a su edad, expectativas lúdicas y necesidades didácticas".

Los talleres son un modo de dinamización cultural que consideramos esenciales en esa relación específica con las instancias escolares que queremos desarrollar, en colaboración con los Gabinetes Pedagógicos ${ }^{12}$.El taller didáctico destinado a alumnos de Bachillerato de la asignatura Patrimonio Histórico de Andalucía u otras materias afines es el elemento más activo de todo el programa cultural que oferta el Centro de Interpretación. También, creemos, el elemento más variado, ya que se pueden ofrecer talleres de:

- Estudios teóricos sobre patrimonio

- Creación de itinerarios patrimoniales por Andalucía

- Técnicas de restauración (diagnosis, limpiezas, reintegraciones y puestas en valor)

- Investigación histórica aplicada a la restauración

- Documentación de bienes

- Técnicas fotográficas aplicadas a la intervención

- Conservación preventiva ${ }^{13}$

${ }^{10}$ Esta cita corresponde a uno de los seis principios de la interpretación propuestos por Tilden (MORALES, 1999:46)

${ }_{11}^{1}$ Obviamente, las actividades y programas destinados al público general incluyen al escolar

${ }_{12}$ En principio se trabajaria con el gabinete pedagógico de Sevilla

${ }^{13}$ Los acuerdos de Vantaa (Finlandia) de septiembre de 2000 establecen una serie de puntos estratégicos y líneas de acción como marco de trabajo para lograr una política y práctica europeas eficaces en materia de conservación preventiva del patrimonio. Entre estos puntos, se incluyen estrategias de cara al público, que debe conocer el concepto de conservación preventiva y participar en él, a través de "programas para garantizar el principio del cuidado compartido de las colecciones, haciendo participar activamente al público y creando un 
Estas actividades didácticas tienen la ventaja de estar orientadas a personas del mismo nivel formativo y de la misma edad ${ }^{14}$ y de ser atendidas por un responsable, guia $o$ monitor que se encarga de ofrecer significados y motivaciones en un entomo ajeno al aula por lo que los estudiantes se muestran más perceptivos a los contenidos transmitidos ${ }^{15}$. En esta dirección, Jorge Morales (1999:67) hace un cuadro comparativo entre el aprendizaje formal y no formal (escuela/centro de interpretación), destacando estos valores del aprendizaje en un centro de visitantes: libertad, motivación interna, variabilidad de contenidos, asistencia voluntaria, duración más libre, especificidad para cada tipo de público, útil para todas las edades y para niveles diversos de experiencias y conocimientos

En principio partiremos de la idea de que todo es comunicable pedagógicamente, aunque, lógicamente, dependerá de nuestro esfuerzo y capacidad el nivel del valor pedagógico de lo transmitido. Comenzaremos haciendo una planificación del taller a nivel de: contenidos curriculares, objetivos, metodología y criterios de evaluación $(\ldots)^{16}$. Posteriormente, habrá que organizar la preparación previa del taller fundamental- con el profesor ${ }^{17}$.

Han de acordarse también los aspectos organizativos ${ }^{18}$;

- solicitud de participación del centro escolar por parte del profesor

- motivos del centro escolar

- tipo de actividad

- tipo de intervención pedagógica que se efectuará (reglada/más libre) de asesoramiento o de seguimiento

- tipo de información que interesa dar a conocer

- día y hora de la actividad

- duración de la intervención (corta/larga duración)

- número de alumnos

- edad

- curso

- nivel (la formación, autonomia e iniciativa de los alumnos)

sentimiento de responsabilidad común hacia el patrimonio cultural" (Hacia una estrategia etropea sobre conservación preventiva, 2000)

${ }^{14}$ Primordialmente trabajaremos con edades 16 a 18 (cursos $1^{\circ}$ y $2^{\circ}$ de Bachillerato), aunque posteriormente se podria trabajar con edades menores

is En algunos casos se podrá acudir hasta el aula, con antelación a la visita, de modo que los alumnos puedan conocer contenidos específicos que luego se van a trabajar en el taller.

${ }_{16}^{16}$ ITURRATE COLOMER, 1999:96

17 Excepcionalmente se podrán organizar cursos de formación o talleres pedagógicos de aprendizaje para profesores o para charlas informativas en grupo sobre el tipo de ayuda que pueden recibir, asi como los materiales y equipos didácticos disponibles.

${ }^{18}$ ITURRATE COLOMER, 1999:96 


\subsection{SERVICIOS PARA PÚBLICOS ESPECIALES}

Si bien el público especial de discapacidad física está plenamente integrado en las actividades y programas definidos para el público general ${ }^{19}$, en principio no se prevén servicios ni actividades para públicos especiales de discapacidad sensorial, aunque, en una segunda fase del Centro de Interpretación, al año aproximado de su apertura se podria evaluar su conveniencia (ver apartado 14 sobre previsiones de variabilidad).

${ }^{19}$ En este sentido, ver 3.5.1.1. Tambièn, la altura de los dispositivos de exposición se situará a $125-150 \mathrm{~cm}$. del suelo 


\section{GESTIÓN}




\subsection{ELECCIÓN DEL SISTEMA DE GESTIÓN}

El Centro de Interpretación para visitantes del Instituto Andaluz del Patrimonio Histórico se gestionará a través del Departamento de Comunicación del IAPH, pues se considera y asi está concebido como una actividad o producto de difusión del propio departamento. Se trata, pues, de un sistema público de gestión. 


\subsection{FÓRMULA ESPECÍFICA DE GESTIÓN}

Entendido como centro generador de difusión del patrimonio, el centro de visitantes ha de lograr, en definitiva, una fórmula de descentralización de la actividad difusora de la institución, así como la apertura de ésta hacia públicos y sectores sociales menos especializados. Por esta razón, el Centro de Interpretación nace con una vocación de participación activa de los usuarios-ciudadanos, por lo que se promoverán fórmulas de gestión muy democráticas $y$, en la medida de lo posible, que permitan la inserción de otros agentes, especialmente gabinetes pedagógicos y centros escolares. La participación de otras empresas, públicas (por ejemplo, para hacerse cargo de la tiendalibreria) o privadas (para responsabilizarse, por poner un caso, de la cafetería) también se tendrá en cuenta.

A su vez, la gestión del Centro de lnterpretación habrá de ser fácilmente evaluable, en cuanto a resultados cuantitativos y cualitativos, con objeto de conseguir una constante mejora de la oferta patrimonial que representa. La evaluación será, entonces, determinante para la gestión del centro, proponiendo el seguimiento de sus efectos y reorientando, en función de ellos, los recursos hacia el logro de los objetivos, a saber: sensibilización del público hacia el patrimonio y conocimiento de una institución que se encarga de tutelarlo. En esta línea, el interés por conocer al público real del centro, así como del público potencial que ya hemos delimitado en el apartado 8.1. nos llevará ineludiblemente a realizar estudios de perfiles de visitantes y encuestas personales acerca de las motivaciones y expectativas de la visita, de los contenidos y servicios existentes en el espacio expositivo.

Este concepto de gestión que manejamos, "entendido como la interacción de formas diversas de demanda y de oferta, de agentes públicos y privados"' que pueden intervenir, deberá estar planificada con previsión y antelación, siempre sin perder de vista su sentido social y de valoración patrimonial, sin olvidar tampoco la necesidad de crear nuevos instrumentos de difusión según se vaya demandando por parte de los visitantes o de otros agentes ${ }^{2}$.

${ }^{1}$ Concepto basado en AA.VV., 1995:45

${ }^{2}$ Para conocer posibles nuevos instrumentos de difusión del Centro de Interpretación ver apartado 1.4. sobre futuras funciones del centro 


\section{3. ÓRGANOS Y SU CONFIGURACIÓN Y COMPOSICIÓN}

La gestión del centro dependerá exclusivamente del Instituto Andaluz del Patrimonio Histórico y de su personal. Concretamente, una estructura bipartita vertebrará la gestion:

a órgano directivo: toma las decisiones económicas y politicas del Centro de Interpretación. Está formado por el director del IAPH, el responsable del Departamento de Comunicación del IAPH y el responsable del Centro de Interpretación.

b. órgano técnico: compuesto por el responsable del Centro de Interpretación y el personal que desarrolla tareas directa o indirectamente para el centro, programa y lleva a cabo las actividades del centro y supervisa el correcto desarrollo de su funcionamiento. Este órgano -descrito más ampliamente en el apartado 10-cuenta, además de con el personal técnico, con una sección de asesores (representantes de los departamentos de Documentación, Intervención y Formación del IAPH), con colaboradores externos (del Gabinete Pedagógico especialmente) y con un grupo de voluntarios culturales. 


\subsection{FORMAS DE GESTIÓN DEL PERSONAL}

El personal que desarrolla labores en el Centro de Interpretación será gestionado desde una perspectiva jerárquica por razones de organización, aunque este modelo de dependencias no impedirá en modo alguno el debate interprofesional y la comunicación multidireccional entre todas las personas integrantes del sistema.

El modelo de organización podrá acercarse a este esquema:

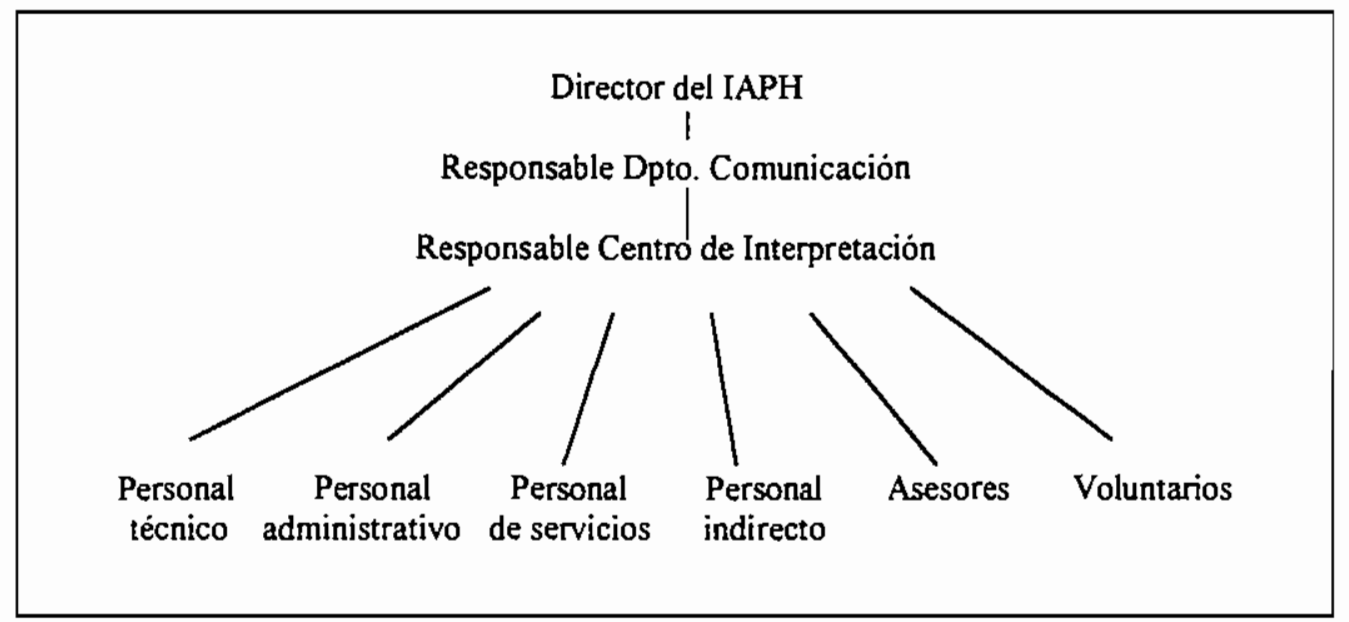




\subsection{FÓRMULAS DE PARTICIPACIÓN SOCIAL}

En correspondencia con el modelo de gestión propuesto, que se pretende claramente participativo (de empresas públicas y privadas, de colaboradores externos y asesores internos y externos), el Centro de lnterpretación del IAPH cuenta con una fórmula de participación șocial añadida, que se define por la creación de un grupo de voluntarios culturales (quizás se podría fundar una Asociación de Voluntarios de Animación Patrimonial). Estos voluntarios prestarian su ayuda puntual en el espacio expositivo del centro, en sus salas de exposición temporal o itinerante o en las áreas de talleres didácticos. El grupo se regularia según la Ley del Voluntariado y sería clave en el desarrollo de futuros convenios de colaboración con otras instituciones (museos, Ayuntamientos, etc.), según lo previsto en el apartado 1.4., sobre futuras funciones del Centro de Interpretación.

Asimismo se plantea la creación de una comisión asesora formada por responsables de distintas entidades profesionales que puedan estar interesadas en el Centro de Interpretación. Esta comisión estaría presidida por el director del IAPH y estaría constituida, además de por los responsables del Departamento de Comunicación y del Centro de Interpretación, por unos ocho miembros, entre los que podrían encontrarse profesores de Bellas Artes (especialidad de restauración y de distintas universidades), responsables de Gabinetes Pedagógicos, profesores de la asignatura Patrimonio Histórico, responsables de asociaciones de voluntariado, etc. 
10. PERSONAL 


\subsection{PERSONAL DIRECTIVO. PERFIL, NÚMERO, FUNCIONES Y OTRAS ESPECIFICACIONES}

El personal directivo del Centro de Interpretación estará compuesto por el director del Instituto Andaluz del Patrimonio Histórico, el responsable del Departamento de Comunicación de la institución y el responsable del Centro de Interpretación del IAPH.

El responsable del Centro de Interpretación será preferiblemente un licenciado en Humanidades con formación o experiencia en difusión del patrimonio o un licenciado en Comunicación o Ciencias de la Información con formación o experiencia en patrimonio. De ser posible, esta persona deberia contar también con formación o experiencia en museología.

Entre sus funciones destaca la responsabilidad teórico-conceptual y financiera del centro (tanto en su vertiente expositiva como didáctica), compartida con el director y el responsable de Comunicación del IAPH. La organización y supervisión de todo to concerniente al Centro de Interpretación, incluidas la tienda-librería y la cafetería, así como la creación y puesta en marcha del grupo de voluntarios son otras de sus competencias, a las que se añaden la promoción del debate, del trabajo en equipo y de la comunicación efectiva entre todos los profesionales implicados en el centro. El responsable del centro tendrá la responsabilidad de iniciar los contactos y colaboraciones con los Gabinetes Pedagógicos y centros escolares, así como de comenzar las tareas de investigación asociadas al sistema de documentación descrito en el capítulo 6, el asesoramiento sobre interpretación y la creación de la red de centros de interpretación patrimonial en Andalucia, competencias todas relativas a las denominadas futuras funciones del Centro de Interpretación (ver 1.4.). 


\subsection{PERSONAL TÉCNICO. PERFIL, NÚMERO, FUNCIONES Y OTRAS ESPECIFICACIONES}

El personal técnico del Centro de Interpretación se divide en tres áreas:

- Espacio expositivo y exposiciones temporales e itinerantes

- Talleres didácticos

- Investigación-documentación

Cada una de estas áreas cuenta con un responsable-técnico que tiene funciones de organización y promoción del área y de concreción y realización de las actividades que le competan.

El responsable del espacio expositivo y exposiciones temporales e itinerantes -con un perfil de licenciado con formación en museología y experiencia en museografia- se encargará de la supervisión del recorrido visitable y se asegurará de su correcto funcionamiento y condiciones de uso. Asimismo propondrá y llevará a cabo las modificaciones que estime oportunas, y controlará la atención que recibe el visitante. Los estudios de público y la evaluación del Centro de Interpretación serán también de su competencia.

Este responsable tendrá la función de coordinarse con asesores internos (de los Departamentos de Documentación, Intervención, Formación y Centro de Arqueología Subacuática), que aconsejarán sobre la adecuación de los contenidos del centro de interpretación y que serán siempre personas que voluntariamente deseen colaborar en la mejora del centro. Igualmente, el responsable del espacio expositivo supervisará el trabajo de los guías.

Igualmente, promoverá y organizará actividades expositivas, del tipo "Ultimas restauraciones del lAPH" o "El Proyecto Alianzas para la Conservación". La conservación de las obras expuestas y el control de las constantes ambientales y de iluminación serán también de su competencia., en colaboración con personal técnico del Centro de Intervención del IAPH.

El responsable de talleres didácticos -licenciado en Pedagogia, Psicología o Ciencias de la Educación con formación en patrimonio o licenciado en Humanidades con experiencia en didáctica- elaborará y realizará programas didácticos con escolares, especialmente de Bachilleratos de Arte y Humanidades. Buscará la colaboración permanente con los Gabinetes Pedagógicos de Bellas Artes, y preparará materiales, guías y cuademos didácticos. Vigilará además el trabajo de diseño de estos materiales, que se encargará a empresas externas. 
El responsable de investigación-documentación, con perfil de investigador y de relaciones públicas, con formación en patrimonio y experiencia en documentación, llevará a cabo (en una segunda etapa del Centro de Interpretación) tareas de asesoramiento y apoyo técnico sobre interpretación a otros agentes en el territorio andaluz. Será asimismo responsable del sistema de documentación (capítulo 6 del presente proyecto) del Centro de Interpretación, un sistema definido en un programa de investigación a tres bandas: I) el IAPH. Historia y evolución, organización, funcionamiento y cumplimiento de objetivos, 2) la comunicación y el público del Centro de Visitantes del Instituto Andaluz del Patrimonio Histórico y 3) la teoría y práctica de la ínterpretación del patrimonio.

Aparte del personal detallado, personal de seguridad, limpieza y mantenimiento del IAPH colaborará en el buen funcionamiento del Centro de Interpretación. Especialmente se contará permanentemente con una persona dependiente orgánicamente del área de mantenimiento que tenga experiencia en montajes museográficos y con otra dependiente del área de seguridad, que vigilará exclusivamente los espacios expositivos. La responsabilidad del trabajo de este personal no recaerá en el responsable del Centro de Interpretación, aunque éste tendrá la obligación de alcanzar una buena relación y colaboración con las distintas áreas, con el convencimiento de que todas trabajan de un modo y otro por los fines de la institución.

El grupo de voluntarios de animación patrimonial -con formación en Humanidades preferiblemente- podrá colaborar en la atención al visitante o en la realización de talleres didácticos. 


\subsection{PERSONAL ADMINISTRATIVO. PERFIL, NÚMERO,} FUNCIONES Y OTRAS ESPECIFICACIONES

El personal administrativo del Centro de Interpretación se definirá en una persona del Departamento de Administración y de Régimen Interno del IAPH, que tendrá las funciones de gestión económica y trámite administrativo de todas las cuestiones relacionadas con el Centro de Interpretación, incluidas las relativas a la tienda-librería y la cafeteria. 


\subsection{PERSONAL SUBALTERNO Y/O DE SERVICIOS. PERFIL, NÚMERO, FUNCIONES Y OTRAS ESPECIFICACIONES}

Además de los dos guías que, con formación en patrimonio y en idiomas, se encargarán de la atención al público de los espacios expositivos permanentes o temporales, se contratará a una empresa de servicios para gestionar la cafeteria del centro.

Por otra parte, personal no dependiente del Instituto Andaluz del Patrimonio Histórico atenderá la tienda-librería, que será gestionada por la Empresa Pública de Gestión de Programas Culturales de la Consejeria de Cultura o por una empresa de las existentes en el sector de tiendas-librerias de museos y lugares patrimoniales. 
Definitivamente, el cuadro de personal del Centro de Interpretación del IAPH queda configurado así:

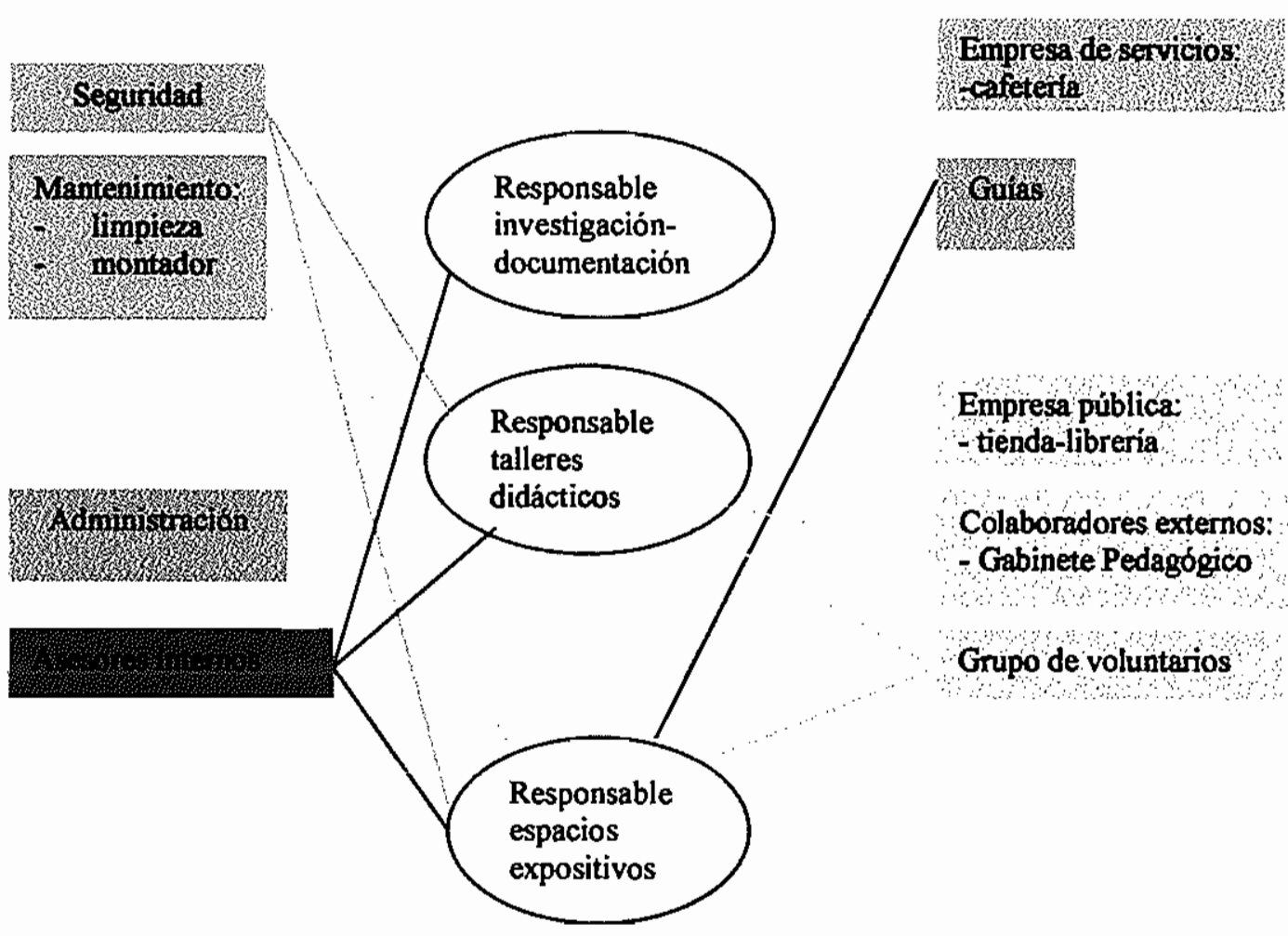




\section{BALANCE PRESUPUESTARIO}




\subsection{APROXIMACIÓN AL COSTE DE APERTURA}

La apertura deI Centro de Interpretación del Instituto Andaluz del Patrimonio Histórico en su complejidad y totalidad, es decir, comprendiendo el recorrido principal de módulos interpretativos, la sala de exposiciones temporales, el área de talleres didácticos, la tienda-librería y la cafeteria, está presupuestada en 27.000 .000 pesetas (162.276'27 euros), cantidad que recoge los gastos previstos desde los 24 meses anteriores a la apertura del centro (momento en el que se contrata a su responsable) hasta el momento de la apertura. En esta cantidad se incluyen igualmente algunos costes laborales:

- recorrido de módulos interpretativos: 21.000 .000 pesetas

Esta cantidad incluye la señalización exterior, el acondicionamiento de las salas al recorrido previsto (paneles de separación de salas y de confección de itinerario, asi como adecuación de los aseos a discapacitados fisicos), la elaboración y montaje de los paneles y módulos interpretativos y el encargo a un artista contemporáneo de cierto renombre la instalación El Círculo del Patrimonio:

- Señalización exterior: 500.000 pesetas

- Acondicionamiento sala: 1.000 .000 pesetas

- Paneles y módulos interpretativos: 19.000 .000 pesetas

- Instalación arte contemporáneo: 1.000 .000 pesetas

- exposiciones temporales: 500.000 pesetas

Corresponde esta cantidad al acondicionamiento de la sala (limpieza, pintura y puesta a punto del sistema de iluminación y climatización existentes).

- actividades didácticas: 500.000 pesetas

Incluye la puesta a punto de la sala, así como la compra de mobiliario (mesas, asientos, pizarras...). 
tienda-libreria: 1.000 .000 pesetas

La cantidad presupuestada comprende el acondicionamiento de la celda de legos destinada a tienda-libreria, y la compra de sillas y mostradores acristalados con cierre de seguridad.

- cafeteria: 500.000 pesetas

Se refiere este presupuesto a la compra de mesas y sillas.

- costes laborales: 3.000 .000 pesetas

Correspondientes al contrato realizado al responsable del Centro de Interpretación el año anterior previsto a la inauguración del centro, para que se encargue de la realización del itinerario, el encargo de la instalación de arte contemporáneo e iniciar la andadura de los programas de exposiciones temporales/itinerantes, talleres didácticos e investigación-documentación. 


\subsection{APROXIMACIÓN AL COSTE DE MANTENIMIENTO}

Referido a los costes previstos desde el momento de la apertura del Centro de Interpretación hasta los doce meses siguientes, es decir, en el primer año de funcionamiento del centro, el coste de mantenimiento asciende a 9.000 .000 pesetas (54.091'09 euros). Con detalle, resulta:

- recorrido de módulos interpretativos ${ }^{\mathrm{l}}: 3.250 .000$ pesetas

La cantidad prevé modificaciones de paneles -por ejemplo en los módulos del Departamento de Formación- (250.000 pesetas), el contrato a responsable técnico de espacios expositivos (2.000.000 pesetas) y el contrato a guía ( 1.000 .000 pesetas).

- exposiciones temporales: 2.500 .000 pesetas

Engloba el presupuesto anual que será destinado a la materialización de exposiciones temporales o itinerantes ( 2.000 .000 pesetas), además del contrato eventual a un guía ( 500.000 pesetas).

- actividades didácticas: 2.500 .000 pesetas

La cantidad presupuestada abarca el contrato a una persona responsable del programa de talleres didácticos ( 2.000 .000 pesetas), así como el material necesario -durante un año- para la realización de estas actividades $\left(500.000^{2}\right.$ pesetas).

- cafetería: 750.000 pesetas

Se refiere este presupuesto al contrato de servicios realizado a la empresa que gestione la cafeteria (máquinas expendedoras de consumiciones).

1 El mantenimiento y seguridad de todas las zonas serán realizados por las Áreas de Mantenimiento y de Seguridad del Instituto Andaluz del Patrimonio Histórico, por lo que no se presupuesta en los gastos del Centro de Interpretación

- A las que hay que sumar 500.000 pesetas aportadas, mediante el correspondiente convenio, por las Consejerias de Cultura y Educación, a través de los Gabinetes Pedagógicos de Bellas Artes, con los cuales se desarrollarán -en colaboración- los talleres didácticos 
12. FINANCIACIÓN 


\subsection{FORMAS DE FINANCIACIÓN}

Entendiendo que la diversificación de la financiación fortalece el proyecto, y buscando la máxima rentabilidad cultural y social, pero también económica y financiera, se establecen tres formas de financiación del centro de visitantes:

I. Básicamente, el centro de visitantes se financiará a través de los presupuestos del Departamento de Comunicación del IAPH, que supondrán un $97 \%$ del total.

2. La financiación del material necesario para el desarrollo de los talleres didácticos será al $50 \%$ en colaboración con las Consejerías de Cultura y Educación, a través de los Gabinetes Pedagógicos de Bellas Artes (que, anualmente, aportarán 500.000 pesetas).

3. La realización de la guía didáctica' y de los productos de recuerdo que se vendan en la tienda (carteles, libretas, posters...) se autofinanciarán, a partir del primer año de creación del centro.

\subsubsection{FINANCIACIÓN DE LA APERTURA}

La financiación de la apertura del centro está supeditada al apoyo de la dirección del Instituto Andaluz del Patrimonio Histórico, que aportará 15.000 .000 de pesetas en dos años (5.000.000 de pesetas el primer año y 10.000.000,el segundo). El Departamento de Comunicación del IAPH contribuirá con 12.000.000 de pesetas en dos años, a razón de 6.000.000 de pesetas cada año. De este modo, en dos años se prevé la apertura del Centro de Interpretación, que está presupuestada en 27.000 .000 pesetas (ver apartado 11).

\subsubsection{MANTENIMIENTO. GARANTÍA DE LA SOSTENIBILIDAD}

A partir de la inauguración del centro, el coste de mantenimiento anual está previsto en 9.000 .000 de pesetas (ver apartado 11). Este presupuesto partirá del presupuesto general del Departamento de Comunicación, previo compromiso por parte del Instituto Andaluz del Patrimonio Histórico de aumentar en 4.500 .000 de pesetas (es decir, el $50 \%$ del coste de mantenimiento) el presupuesto anual del citado Departamento.

\footnotetext{
' El coste de la guia será cubierto por la venta al público de ésta a un precio módico de 100 pesetas
} 


\section{EJECUCIÓN}




\subsection{DESCRIPCIÓN GENERAL}

La ejecución del presente proyecto se iniciará en enero del año 2002, momento en el Departamento de Comunicación del IAPH contratará al responsable del Centro de Interpretación. Durante dos años, esta persona se encargará de realizar la exposición permanente, confeccionar el programa de exposiciones temporales e itinerantes, marcar las líneas de trabajo y establecer contactos y colaboraciones en relación a los programas de didáctica y de investigación-documentación. Durante estos dos años se contará con la aportación presupuestaria del Departamento de Comunicación y del IAPH de 27.000 .000 pesetas.

La inauguración del Centro de Interpretación y la puesta en marcha de toda su actividad paralela y complementaria será en enero del año 2004, cumplidos los dos años de la fase de preparación. Solamente el programa de investigación-documentación se pondrá en marcha un año más tarde, en enero del 2005. 


\subsection{PLAZOS Y CRONOGRAMA}

\begin{tabular}{|c|c|}
\hline Julio 2001 & $\begin{array}{l}\text { Presentación del proyecto a la dirección del Instituto Andaluz } \\
\text { del Patrimonio Histórico y ai Departamento de Comunicación de } \\
\text { la institución }\end{array}$ \\
\hline Septiembre-noviembre 2001 & $\begin{array}{l}\text { Evaluación del proyecto por parte de la dirección del Instituto } \\
\text { Andaluz del Patrimonio Histórico y el Departamento de } \\
\text { Comunicación de la institución }\end{array}$ \\
\hline Diciembre 2001 & Informe de aceptación del proyecto \\
\hline Enero 2002 & $\begin{array}{l}\text { Comienza la ejecución o fase preparatoria del Centro de } \\
\text { Interpretación y de todas sus actividades agregadas. Se contrata } \\
\text { al responsable del centro }\end{array}$ \\
\hline Enero 2004 & $\begin{array}{l}\text { Inauguración del Centro de Interpretación: recorrido principal o } \\
\text { exposición permanente, saia de exposiciones temporales, taller } \\
\text { de actividades didácticas, tienda-libreria y cafeteria }\end{array}$ \\
\hline Enero 2005 & $\begin{array}{l}\text { Evaluación del Centro de Interpretación. Desarrollo del } \\
\text { programa de investigación-documentación }\end{array}$ \\
\hline
\end{tabular}




\section{PREVISIONES DE CRECIMIENTO, VARIABILIDAD Y VERSATILIDAD}




\subsection{PREVISIONES}

En una fase avanzada de la puesta en marcha del Centro de Interpretación se hace necesaria la realización de un sistema de evaluación general del mismo. Este sistema (que podria realizarse a través de la conjunción de diversas técnicas de estudio de público: observación de comportamientos in situ, buzones de sugerencias, encuestas de opinión, cuestionarios, etc), además de detectar deficiencias, originaria la localización y descubrimiento de nuevas demandas y precisiones. A continuación establecemos algunas hipotéticas pero probables futuras situaciones:

\section{PREVISIONES DE CRECIMIENTO:}

Dado el destacado lugar que ocupa la institución en el ámbito patrimonial actual y el interés -en crecimiento- que siempre ha suscitado para el público (el especializado y el más general) visitarla y conocerla, se prevé un aumento considerable de los visitantes (público visitante del Monasterio y CAAC, público escolar o grupos de asociaciones y organizaciones...) que puedan acudir al Centro de Interpretación, tanto en su faceta de centro de visitantes/exposición permanente como en su vertiente de sala de exposiciones temporales temáticas o sobre últimas intervenciones.

Se hace previsible igualmente un incremento de los grupos de trabajo didáctico que, de seguro, una vez iniciados y puestos en marcha levantarán gran interés en el profesorado de Bachillerato.

\section{PREVISIONES DE VARIABILIDAD}

Quizás en algún momento las solicitudes para realizar talleres didácticos procedan de horquillas educativas de edades diferentes a las previstas, por ejemplo, de edades infantiles, de 6 a 12 años.

Es probable también que, dada la variada oferta cultural del centro y la tendencia del público visitante del IAPH a fidelizarse (ver apartado 8.1.), se establezca un hábito de visita al Centro de Interpretación por parte del sector del público potencial más interesado en cuestiones patrimoniales o culturales.

Por último, y como se adelantaba en el apartado 8.5., se prevé la posibilidad -en función de la demanda que se pueda originar- de hacer un acercamiento mayor del planteado en este proyecto hacia los públicos especiales. 


\section{PREVISIÓN DE VERSATILIDAD}

Entendido el centro de visitantes como un lugar de encuentro socio-cultural, se prevé gran dinamismo - si se fornenta- alrededor de su actividad. 


\subsection{SOLUCIONES}

En cuanto a las previsiones de crecimiento de público general, se podria establecer como solución una oferta alternativa, complementaria y atractiva para este tipo de público, por ejemplo, estableciendo un acuerdo con el Centro Andaluz de Arte Contemporáneo/Monasterio de La Cartuja para interpretar el lugar histórico en el que se ubican las tres instituciones. Se podria hacer un recorrido histórico con puntos de contemplación.

En caso de incrementarse considerablemente el número de solicitudes para realizar actividades didácticas, la solución habria de pasar por una distribución homogénea de los grupos a lo largo del curso escolar, impidiendo la acumulación en los últimos meses del curso (abril-mayo), como es de sospechar.

En segundo lugar, y en relación con las previsiones de variabilidad, deberiamos satisfacer las demandas de realización de talleres didácticos para niños con la misión de sensibilizar al público desde las más tempranas edades. Nuevamente, la colaboración con los Gabinetes Pedagógicos de Bellas Artes se haría imprescindible.

Por supuesto, pensando en la posibilidad de alcanzar un alto grado de visitas reiteradas entre el público más fiel e interesado en nuestra oferta, se prevé una necesidad de modificación de contenidos rotativa o variable con el tiempo (quizás cada dos o tres años). A corto plazo, esta previsión de variabilidad en relación a la frecuencia de la visita se ve satisfecha con el programa de exposiciones temporales y la modificación periódica prevista para algunos módulos interpretativos, como el de la oferta formativa del IAPH que habrá de estar siernpre actualizada.

En el hipotético caso de que se decidiera acceder al público especial, se podria crear un Programa para público especial (similar al de público extranjero) que contaría con productos y servicios específicos: a) maletín a modo de resumen de la exposición en braille y/o cintas de audio con algunos textos de los paneles más importantes y b) taller didáctico donde se pudieran tocar objetos ${ }^{\downarrow}$, manipular materiales, oler sustancias, escuchar sonidos... Este programa estaría en estrecha interrelación con los programas de atención al público y de voluntariado. Los guias y personal de seguridad recibirían cursos para atender adecuadamente a públicos especiales.

\footnotetext{
${ }^{1}$ Las imágenes táctiles, por ejemplo, de material termoformado (imágenes en relieve de aigunas zonas de los cuadros) son una manera de permitir que los visitantes reciban una percepción sensorial (HOOPER-GREENHILL, 1998:150). En relieve, y en reproducciones de pinturas, se podrian reproducir las lagunas, o las reintegraciones, etc. y asi posibilitar la interpretación del área de tratamiento del IAPH.
} 
Finalmente, en relación a las previsiones de versatilidad, podemos asegurar que la apertura de la zona de exposiciones temporales puede ser un modo de apertura social, especialmente si se ofrece la posibilidad de alternar en este espacio expositivo muestras de la institución con muestras o actividades propuestas por otros agentes socioculturales (ayuntamientos, profesionales, instituciones museísticas, asociaciones culturales, etc.). 
15. BIBLIOGRAFÍA 


\subsection{BIBLIOGRAFÍA C.ITADA Y CONSULTADA SOBRE EL CONTENIDO Y LA TEMÁTICA CIENTÍFICA}

I0 años para innovar desde la memoria (2000): Instituto Andaluz del Patrimonio Histórico, Junta de Andalucía, Sevilla.

Actualización de los criterios para la selección de bienes culturales muebles objeto de investigación, conservación y restauración en el Instituto Andaluz del Patrimonio Histórico (1998) en PH. Boletín del Instituto Andaluz del Patrimonio Histórico, $\mathrm{n}^{\circ} 23$. Junta de Andalucía, Sevilla.

AMAT, N. (1998): Documentación cientifica y nuevas tecnologias de la información. Pirámide, Madrid.

BALDINI, U. (1997): Teoría de la restauración. Nerea/Nardini, Madrid/Florencia.

BALLART, J. (1997): El patrimonio histórico y arqueológico: valor y uso. Ariel, Barcelona.

BENAVIDES, J. (1995): "Siete enunciados sobre la teoría general del Patrimonio Cultural" en PH. Boletin del Instituto Andaluz del Patrimonio Histórico, $\mathrm{n}^{\circ} 12$. Junta de Andalucía, Sevilla.

BERNÁLDEZ SÁNCHEZ, E. (1998): "Encontré un fósil y no supe qué hacer con él" en PH. Boletin del Instituto Andaluz del Patrimonio Histórico, $\mathrm{n}^{\circ} 24$. Junta de Andalucia, Sevilla.

BOLÍVAR GALIANO, F. (1995): "Los agentes de biodeterioro del patrimonio pictórico, textil y gráfico" en PH. Boletín del Instituto Andaluz del Patrimonio Histórico, $\mathrm{n}^{\circ} 12$. Junta de Andalucía, Sevilla.

BRANDI, C. (1988): Teoria de la Restauración. Alianza, Madrid.

BRYSON, J. (1992): Técnicas de gestión para bibliotecas y centros de información. Fundación Germán Sánchez Ruipérez, Madrid.

BURGESS, F. (1990): Chemical Science and Conservation. MacMillan, London.

CANEVA, G., NUGARY, M.P. y SALVADORI, O. (2000): La biologia en la restauración. Nerea/IAPH, Hondarribia (Guipúzcoa). 
CASTILLO RUIZ, J. (I998): "El nacimiento de la tutela como disciplina autónoma: Alöis Riegl" en PH. Boletín del Instituto Andaluz del Patrimonio Histórico, $\mathrm{n}^{\circ} 22$. Junta de Andalucia, Sevilla.

COLORADO CASTELLARY, A. (1999): "El Reto Hipermedia en la difusión del Patrimonio Cultural", en PH. Boletín del Instituto Andaluz del Patrimonio Histórico, $n^{\circ} 26$. Junta de Andalucía, Sevilla.

COLL-VINENT, R. (1978): Teoria y práctica de la documentación. A.T.E., Barcelona.

CURRÁS, E. (I982): Las ciencias de la documentación: Bibliotecologia, archivologia, documentación e información. Mitre, Barcelona.

DE GUICHEN, G. (1984): "Enseñar a conservar el patrimonio" en Revista Museum, $\mathbf{n}^{\circ}$ 144 , UNESCO, Paris.

De l'utilité du patrimoine (1992). Actes des Colloques de la Direction du Patrimoine, Ministère d'Education, Culture et Communication, Paris.

DUPAVILLON, C.: “Qu'est-ceque le patrimoine?" en LANG, J. (1992): Regards sur le patrimoine. Direction du Patrimoine du Ministère de l'Education National et de la Culture, Paris.

FERNÁNDEZ SALINAS, V. y otros (1996): Bases para una carta sobre patrimonio y desarrollo en Andalucía. Instituto Andaluz del Patrimonio Histórico, Sevilla.

FERNÁNDEZ-BACA, R. (1999): "Patrimonio Histórico, cohesión social e innovación" en $P H$, Boletín del Instituto Andaluz del Patrimonio Histórico, $\mathrm{n}^{\circ} 25$. Junta de Andalucía, Sevilla.

FERNÁNDEZ-BACA, R. (2000): Fragmentos no literales de la conferencia pronunciada en el marco del I Seminario Internacional de Institutos de Patrimonio. Documento interno, Instituto Andaluz del Patrimonio Histórico, Sevilla.

FERRERAS ROMERO, G. (1994): "Las relaciones entre historiadores del arte y demás especialistas de la conservación y restauración" en PH. Boletín del Instituto Andaluz del Patrimonio Histórico, $n^{\circ}$ 9. Junta de Andalucía, Sevilla.

GALLARDO, B. (1999): "Problemas y perspectivas teóricos en torno a la tutela del patrimonio artístico del siglo XX", en PH. Boletín del Instituto Andaluz del Patrimonio Histórico, n²9. Junta de Andalucia, Sevilla.

GERMAINE, S. (1993): La mujer llorosa en las calle de Praga. Daedaelus. 
GÓMEZ FERNÁNDEZ-CABRERA, J.: "El profesional de la información / documentación" en GARCIA CUTIÉRREZ, A. (1999.): Introducción a la documentación informativa y periodistica, MAD, Sevilla.

GONZÁLEZ LÓPEZ, M.J. (1995): "Metodologia de estudio y criterios de intervención en escultura polictomada en el IAPH" en PH. Boletín del Instituto Andaluz del Patrimonio Histórico, $\mathrm{n}^{\circ} 12$. Junta de Andalucia, Sevilla.

PLENDERLEITH, H. J. (1967): La conservación de antigüedades y obras de arte. Instituto Central de Conservación y Restauración de Obras de Arte, Arqueología y Etnologia, Mádrid.

HENARES CUÉLLAR, I. (1998): "Conocimiento histórico y tutela" en Historia del Arte y Bienes Culturales. Cuademo VIII. Instituto Andaluz del Patrimonio Histórico, Junta de Andalucía, Sevilla.

HORNOS MATA, F. (1994): "Reflexiones acerca del Patrimonio Arqueológico Inmueble y su conservación" en Conservación Arqueológica. Cuaderno III. Instituto Andaluz del Patrimonio Histórico, Junta de Andalucía, Sevilla.

Informe sobre el concepto, funciones y servicios, función social y propuesta de planificación del Instituto Andaluz del Patrimonio Histórico para la V Legislatura (1994). Documento interno. Instituto Andaluz del Patrimonio Histórico, Sevilla

Informe sobre el papel del Instituto Andaluz del Patrimonio Histórico (1990). Documento interno. Instituto Andaluz del Patrimonio Histórico, Sevilla.

Instituto de Conservación y Restauración de Bienes Culturales (1990): Ministerio de Cultura, Madrid.

KIRSHENBLATT-GIMBLETT, B. (1998): Destination culture: Tourism, Museums and Heritage. Berkeley, University of California Press.

La formación en el LAPH (1996) en PH. Boletín del Instituto Andaluz del Patrimonio Histórico, $\mathrm{n}^{\circ}$ 16. Junta de Andalucia, Sevilla.

LADRÓN DE GUEVARA, C. (1996): "El Centro de Documentación del Patrimonio Histórico. Objetivos, Gestión, Servicios" en PH. Boletín del Instituto Andaluz del Patrimonio Histórico, $\mathrm{n}^{\circ} 15$. Junta de Andalucia, Sevilla.

LANG, J. (1992): Regards sur le patrimoine. Direction du Patrimoine du Ministère de l'Education National et de la Culture, París.

Ley de Patrimonio Histórico Español, Ley 16/1985, del 25 de junio de 1985. 
LÓPEZ YEPES, J. (1996): Manual de Información y Documentación. Pirámide, Madrid.

LOSADA ARANGUREN, J.M. (1999): "Teoria y praxis de la conservación: el rol del historiador del arte" en PH. Boletín del Instituto Andaluz del Patrimonio Histórico, $\mathrm{n}^{\circ} 28$. Junta de Andalucia, Sevilla.

MARTín, M. (1993): "Difusión del Patrimonio I: La Historia" en PH. Boletín del Instituto Andaluz del Patrimonio Histórico, $\mathrm{n}^{\circ} 5$. Junta de Andalucia, Sevilla.

MARTIN, M.'(1994): "Patrimonio. Breves reflexiones en torno al final del milenio" en PH. Boletín del Instituto Andaluz del Patrimonio Histórico, $\mathrm{n}^{\circ} 7$. Junta de Andalucia, Sevilla.

MARTÍN, M. (1998): "Reflexiones en tomo a la difusión del patrimonio" en Difusión del Patrimonio Histórico. Cuaderno VII. Instituto Andaluz del Patrimonio Histórico, Junta de Andalucía, Sevilla.

MARTÍNEZ JUSTICIA, M.J. (1996): Antologia de textos sobre restauración. Universidad de Jaén, Jaén.

MATTEINl, M. y MOLES, A. (2001): Ciencia y restauración. Nerea/Instituto Andaluz del Patrimonio Histórico, Guipúzcoa

MIGONE RETTIG, J. y PIROZZI VILLANUEVA, A. (1999): Conservación del patrimonio cultural. Cartas y Recomendaciones Internacionales. CONPAL (Centro para la Conservación del Patrimonio Arquitectónico Latinoamericano), Chile.

MUÑ̃Z CRUZ, V. (1998): "La Red de Información de Patrimonio Histórico Andaluz: un instrumento para la gestión eficaz en Bienes Culturales" en PH. Boletín del Instituto Andaluz del Patrimonio Histórico, $\mathrm{n}^{\circ} 25$. Junta de Andalucía, Sevilla.

Objetivos y Programas del Instituto Andaluz del Patrimonio Histórico en marzo de 1991 (documento interno). Instituto Andaluz del Patrimonio Histórico, Junta de Andalucia, Sevilla.

OJEDA CALVO, R. y TABALES RODRÍGUEZ, M.A. (1996): "La investigación arqueológica en Bienes Inmuebles. Metodología aplicada en la Puerta de Córdoba de Carmona" en PH. Boletín del Instituto Andaluz del Patrimonio Histórico, $n^{\circ} 15$. Junta de Andalucia, Sevilla.

PÉREZ ALVAREZ-OSSORIO, J. R. (1988): Introducción a la información y documentación cientifica. Alhambra, Madrid. 
PÉREZ DEL CAMPO, L. (1996.): "El Centro de Intervención en el Patrimonio Histórico. Método, Objetivo y Servicios" en PH. Boletín del Instituto Andaluz del Patrimonio Histórico, $\mathrm{n}^{\circ} 14$. Junta de Andalucia, Sevilla.

PORRO GUTIÉRREZ, J. (1995): "Patrimonio y cultura: dos términos en interacción" en en PH. Boletin del Instituto Andaluz del Patrimonio Histórico, $\mathrm{n}^{\circ} 12$. Junta de Andalucia, Sevilla.

Programa especial para la planificación del Instituto Andaluz del Patrimonio Histórico. I Plan General de Bienes Culturales. Consejeria de Cultura y Medio Ambiente, Junta de Andalucia.

RODRIGUEZ TEMIÑO, 1. (2000): "Pasado, historia y patrimonio histórico". Resumen de la clase "Evolución del concepto de Patrimonio Histórico". I Máster de Museologia, Consejería de Cultura/Universidad de Granada.

ROMERO MORAGAS, C. (1993): "Patrimonio y Desarrollo" en PH. Boletín del Instituto Andaluz del Patrimonio Histórico, $\mathrm{n}^{\circ} 4$. Junta de Andalucía, Sevilla.

ROS GARCÍA, J. y LÓPEZ YEPES, J. (1994): Políticas de información y documentación. Síntesis, Madrid.

SAENZ DE TEJADA, A. (2001): Conservación preventiva en textiles, metales, papel, pintura sobre tabla y lienzo en www.anticuarius. com $/ \mathrm{html} / \mathrm{magazine} /$ conservacion.

TUNBRIDGE, J.E. and ASHWORTH, G. J. (1996): Dissonant Heritage. The management of the past as a resource in conflict. Wiley, Chischester.

WARD, Philip (1982): "La conservación: el porvenir del pasado" en La Conservación: un desafio a la profesión, Revista Museum, vol. XXIV, $\mathrm{n}^{\circ} 1$, UNESCO, París.

www.iphan.gob

www.cicop.co

www. ipc.gov.ve

www.getty.edu/gci

www.mec.gub.uy/com_patri

www.aragob.es/edycul/patrimo/genel

www.progettomose.it

www.beniculturali.it 
www.beniculturali.it/restauri/istituti

www.icr.arti.beniculturali.it

www.si.edu/activity

www.iaph.junta-andalucia.es

www.sunsite.unam.mx/antropol

www.european-heritage.net

www.english-heritage.org.uk

www.culture.fr

www.segegob.cl/secc/cultura 


\subsection{BIBLIOGRAFÍA CITADA Y CONSULTADA SOBRE INTERPRETACIÓN, MUSEOLOGÍA Y MUSEOGRAFÍA}

AA.VV.(1995): El museo comarcal, la difisión del Patrimonio y la planificación territorial de las politicas culturales en PH. Boletín del Instituto Andaluz del Patrimonio Histórico, $\mathrm{n}^{\circ}$ 13. Junta de Andalucia, Sevilla.

ALONSO FERNÁNDEZ, L. (1999): Introducción a la nueva museologia. Alianza, Madrid.

ALONSO FERNÁNDEZ, L.: "La Conservación Preventiva antes de los 80" en HIDALGO CUÑARRO, José Manuel (1996): Actas del Coloquio Internacional "La Conservación Preventiva de Bienes Culturales", Vigo, Diputación Provincial de Pontevedra

ARAMINI, F. (1993): "Iluminación y estudios colorimétricos aplicados a la exposición del bien cultural" en Un proyecto para la Capilla Real de Granada. Serie Cuadernos del Instituto Andaluz del Patrimonio Histórico. Junta de Andalucía, Sevilla.

ARDEMAGNI, M. (1996): "La conservación preventiva y el gran público" en HIDALGO CUÑARRO, J.M. (1996): Actas del Coloquio Internacional "La Conservación Preventiva de Bienes Culturales", Vigo, Diputación Provincial de Pontevedra.

BAGLIONI, R. (1999): "La iluminación de un bien cultural. Problemas conservativos y nuevos avances" en PH. Boletín del Instituto Andaluz del Patrimonio Histórico, $\mathrm{n}^{\circ}$ 23. Junta de Andalucia, Sevilla.

BELCHER, M. (1994): Organización y diseño de exposiciones. Trea, Gijón.

CARRIER, C. (1999): "Teoria y prácticas de la interpretación" en $P H$. Boletín del Instituto Andaluz del Patrimonio Histórico, $\mathrm{n}^{\circ} 25$. Junta de Andalucía, Sevilla.

CASTELLÓN SERRANO, F. y otros (1998): "Los Gabinetes Pedagógicos de Bellas Artes y la difusión del Patrimonio Histórico" en Difusión del Patrimonio Histórico. Cuaderno VII. Instituto Andaluz del Patrimonio Histórico, Junta de Andalucía, Sevilla.

CUENCA CABEZA, M. (1999): Ocio y Equiparación de Oportunidades. Documentos de Estudio de Ocio, $\mathrm{n}^{\circ} 6$. ONCE / Universidad de Deusto, Bilbao.

DE GUICHEN, G. (1999): "La conservación preventiva: ¿simple moda pasajera o cambio trascendental? en Museum International, UNESCO, $\mathrm{n}^{\circ} 201$. 
DÍAZ BALERDI, I. (1994): Miscelánea museológica. Universidad del País Vasco, Bilbao.

DOMINGUEZ PILA, M. (2000): La seguridad en los museos (documentación inédita). I Máster en Museologia, Universidad de Granada.

Gabinete Pedagógico. Información. Cuademo de presentación. Gabinete Pedagógico de Bellas Artes de Sevilla, Junta de Andalucía, Sevilla, 1999.

GARCÍA, J.M. (1999): "Visita a la gran ciudad que no existe. La interpretación del patrimonio en la red", en PH. Boletín del Instituto Andaluz del Patrimonio Histórico, $\mathrm{n}^{\circ} 25$. Junta de Andalucía, Sevilla.

GARCÍA DE LA TORRE, F. (2000): Concepto y técnicas de conservación preventiva (documentación inédita). I Máster en Museología, Universidad de Granada.

GARCÍA FERNÁNDEZ, I.M. (1999): La conservación preventiva y la exposición de objetos y obras de arte. $\mathrm{KR}$, Murcia.

Hacia una estrategia europea sobre conservación preventiva (2000). Documento inédito, adoptado en la Reunión sobre Conservación Preventiva de Vantaa, Finlandia.

HERNÁNDEZ HERNÁNDEZ, F. (1994): Mamual de Museologia. Sintesis, Madrid.

HERNÁNDEZ HERNÁNDEZ, F. (1998): El museo como espacio de comunicación. Trea, Gijón.

HIDALGO CUÑARRO, J.M. (1996): Actas del Coloquio Internacional "La Conservación Preventiva de Bienes Culturales", Vigo, Diputación Provincial de Pontevedra.

HOOPER-GREENHILL, E. (1998): Los museos y sus visitantes. Trea, Gijón.

ICOM (1971): La lumière et la protection des objets et specimenes exposés dans les musées et galeries d'art. Association Française de L'Eclairage.

ICOM (1993): Museum security and protection. Routledge, London.

"Interpretation du patrimoine" (1997) en Les cahiers espaces. Actas del Coloquio. Auvers sur Oise, dic. 1996.

ITURRATE COLOMER, G. (1999): "La función pedagógica del archivo. Aplicaciones didácticas en forma de talleres de historia, tecnológicos y audiovisuales" en PH. Boletin del Instituto Andaluz del Patrimonio Histórico, $\mathrm{n}^{\circ} 24$. 
LÓPEZ BARBOSA, F. (1993): Manual de Montaje de Exposiciones. Museo Nacional de Colombia, Bogotá.

LORD, B. y LORD, G.D. (1998): Manual de gestión de museos. Ariel, Barcelona.

MIRÓ I ALAIX, M. (1997): "Interpretación, identidad y territorio. Una reflexión sobre el uso social del patrimonio" en PH. Boletín del Instituto Andaluz del Patrimonio Histórico, $\mathrm{n}^{\circ}$ 18. Junta de Andalucía, Sevilla.

MORALES, J. (1998): Guía Práctica para la Interpretación del Patrimonio. El arte de acercar el légado natural y cultural al público visitante. Junta de Andalucía, Consejeria de Cultura: Empresa Pública de Gestión de Programas Culturales, Sevilla.

MORALES, J. (1999): "La interpretación del patrimonio natural y cultural: todo un camino por recorrer", en PH. Boletín del Instituto Andaluz del Patrimonio Histórico, $\mathbf{n}^{\circ}$ 25. Junta de Andalucía, Sevilla.

Museum (1982), vol. XXIV, $\mathrm{n}^{\circ}$ 1. Especial "La Conservación: un desafio a la profesión", UNESCO, París.

NARDI, R. (1999): "Implicar al público: un nuevo enfoque de la educación para la conservación", en Museum, n 201, UNESCO, Paris.

PADRÓ WERNER, J. (1998): "La interpretación: un método dinámico para promover el uso social del Patrimonio Cultural y Natural" en Difusión del Patrimonio Histórico. Cuaderno VII. Instituto Andaluz del Patrimonio Histórico, Junta de Andalucía, Sevilla.

RAVÉ PRIETO, J.L. (1998): "Difusión del Patrimonio Histórico en Andalucía" en Difusión del Patrimonio Histórico. Cuaderno VII. Instituto Andaluz del Patrimonio Histórico, Junta de Andalucia, Sevilla.

RIVIĖRE, G.H. (1993): La museología: curso de museologia. Textos y testimonios. Akal, Madrid.

RODRÍGUEZ EGUIZÁBAL, Á.B. (2001): "Nueva sociedad, nuevos museos" en $P H$. Boletín del Instituto Andaluz del Patrimonio Histórico, $\mathrm{n}^{\circ} 34$. Iunta de Andalucía, Sevilla.

RUNYARD, S. (1994): The Museum Marketing Handbook. HMSO, London.

SÁNCHEZ DE HORCAJO, J.J. y otros (1995): "Los museos y su público" en Revista de Museología, $\mathrm{n}^{\circ} 5$.

SAN MARTÍN MONTILLA, C. (1999): "El museo integral del territorio" en Revista de Museología, $\mathrm{n}^{\circ} 13$. 
SIVAN, R. (1999): "Dialogar con el pasado. Comunicar con el legado", en PH. Boletin del Instituto Anctaluz del Patrimonio Histórico, $\mathrm{n}^{\circ} 25$. Junta de Andalucia, Sevilia.

SONTAG. S. (1996): Contra la interpretación. Alfaguara, Madrid.

STERRY, P. (1998): "Extender los límites de la interpretación: entorno antiguo, visión novedosa" en Museum, $\mathrm{n}^{\circ} 199$, UNESCO, París.

THOMSON, G. (1986): The Museum Environment. Butterworth-Heinemann, Londres.

TILLOTSOT,'R. (1980): La seguridad en los museos. Madrid, Ministerio de Cultura.

UZZELL, D. (1989): Heritage Interpretation. Vol I: The Natural and Built Environment. Belhaven Press, London.

ZITNIK, A. (1985): "Planificación de Iluminación en el Museo" en ERCO Iluminación Lichtbericht 20/2. 
Interpretación, entonces. Comunicación dedicada a la actitud, inquietud para el gran público, evasión y éxodo de saberes y valores para sensibilizar... Del patrimonio, claro, de esa gran cuestión ética que nos atañe y va pidiendo en silencio y a gritos nuestro compromiso, ahora que, como siempre, el cuerpo de la historia es un hombre inundado que ha yacido largo tiempo en el lecho del mar, y la mayor parte de la carne esiá destrozada, la mayor parte de las conchas, las flores de la madreperla, el aumento de lágrimas y sangre se multiplican...

El círculo nos rodea. 